\title{
Mathematical Analysis of a Novel Approach to Maximize Waste Recovery in a Life Support System
}

The INL is a

U.S. Department of Energy

National Laboratory

operated by

Battelle Energy Alliance

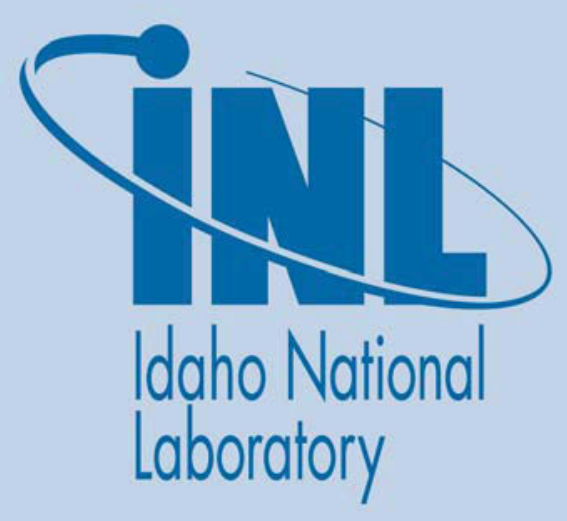

Michael G. McKellar

Rick A. Wood

Carl M. Stoots

Lila Mulloth

Bernadette Luna

February 2011 



\section{DISCLAIMER}

This information was prepared as an account of work sponsored by an agency of the U.S. Government. Neither the U.S. Government nor any agency thereof, nor any of their employees, makes any warranty, expressed or implied, or assumes any legal liability or responsibility for the accuracy, completeness, or usefulness, of any information, apparatus, product, or process disclosed, or represents that its use would not infringe privately owned rights. References herein to any specific commercial product, process, or service by trade name, trade mark, manufacturer, or otherwise, does not necessarily constitute or imply its endorsement, recommendation, or favoring by the U.S. Government or any agency thereof. The views and opinions of authors expressed herein do not necessarily state or reflect those of the U.S. Government or any agency thereof. 



\title{
Mathematical Analysis of a Novel Approach to Maximize Waste Recovery in a Life Support System
}

\author{
Michael G. McKellar \\ Rick A. Wood \\ Carl M. Stoots \\ Idaho National Laboratory \\ Lila Mulloth \\ Bernadette Luna \\ NASA Ames Research Center
}

February 2011

Idaho National Laboratory High Temperature Electrolysis

Idaho Falls, Idaho 83415

http://www.inl.gov

Prepared for the

National Aeronautics and Space Administration and for the

U.S. Department of Energy

Under DOE Idaho Operations Office

Contract DE-AC07-05ID14517 



\section{Mathematical Analysis of a Novel Approach to Maximize Waste Recovery in a Life Support System}

INL/EXT-11-21041

February 2011

Approved by:
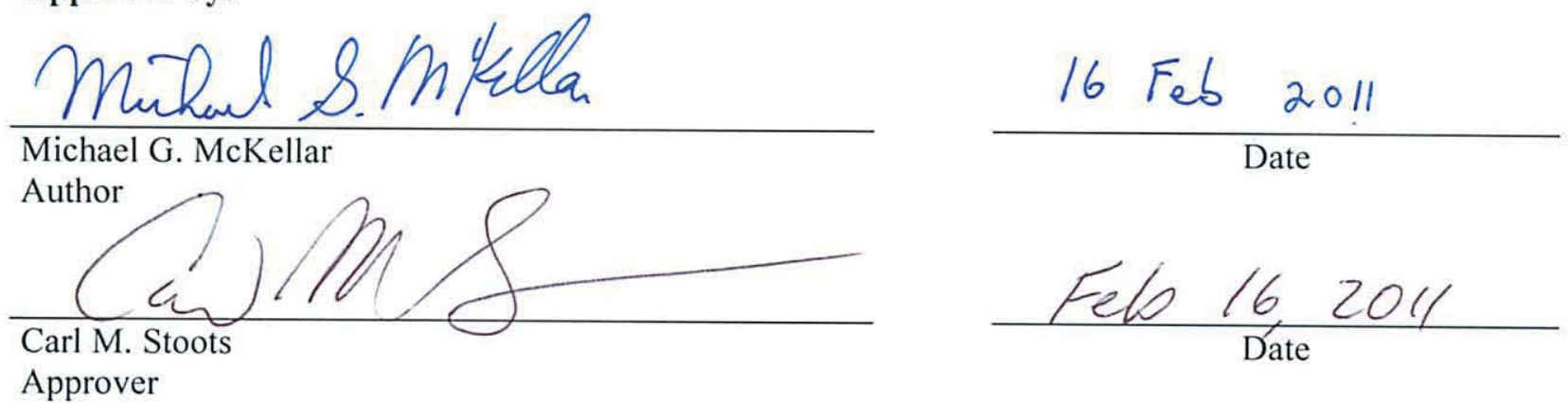



\section{SUMMARY}

NASA has been evaluating closed-loop atmosphere revitalization architectures that include carbon dioxide $\left(\mathrm{CO}_{2}\right)$ reduction technologies. The $\mathrm{CO}_{2}$ and steam $\left(\mathrm{H}_{2} \mathrm{O}\right)$ co-electrolysis process is one of the reduction options that NASA has investigated. Utilizing recent advances in the fuel cell technology sector, the Idaho National Laboratory, INL, has developed a $\mathrm{CO}_{2}$ and $\mathrm{H}_{2} \mathrm{O}$ co-electrolysis process to produce oxygen and syngas (carbon monoxide $(\mathrm{CO})$ and hydrogen $\left(\mathrm{H}_{2}\right)$ mixture) for terrestrial (energy production) application. The technology is a combined process that involves steam electrolysis, $\mathrm{CO}_{2}$ electrolysis, and the reverse water gas shift (RWGS) reaction. Two process models were developed to evaluate novel approaches for energy storage and resource recovery in a life support system. In the first model, products from the INL co-electrolysis process are combined to produce methanol fuel. In the second co-electrolysis, products are separated with a pressure swing adsorption (PSA) process. In both models the fuels are burned with added oxygen to produce $\mathrm{H}_{2} \mathrm{O}$ and $\mathrm{CO}_{2}$, the original reactants. For both processes, the overall power increases as the syngas ratio, $\mathrm{H}_{2} / \mathrm{CO}$, increases because more water is needed to produce more hydrogen at a set $\mathrm{CO}_{2}$ incoming flow rate. The power for the methanol cases is less than pressure swing adsorption, PSA, because heat is available from the methanol reactor to preheat the water and carbon dioxide entering the co-electrolysis process. 


\section{CONTENTS}

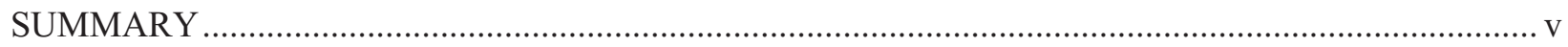

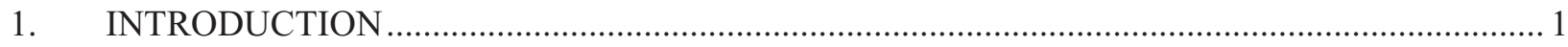

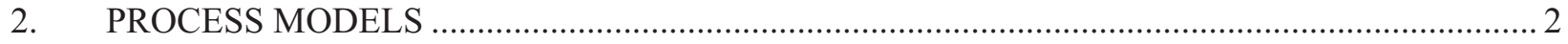

2.1 Co-Electrolysis Integrated Process Models ...................................................................... 2

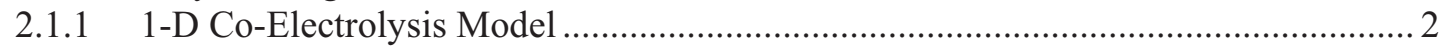

2.1.2 Implementation of Co-Electrolysis Model into UniSim ...................................... 6

2.2 Methanol Process with Co-electrolysis ........................................................................ 8

2.3 Co-electrolysis with Pressure Swing Adsorption........................................................... 11

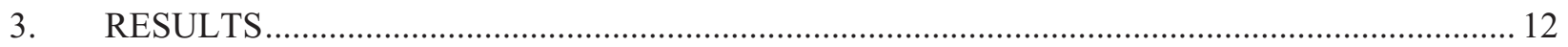

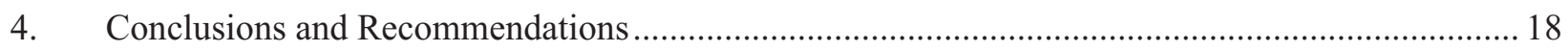

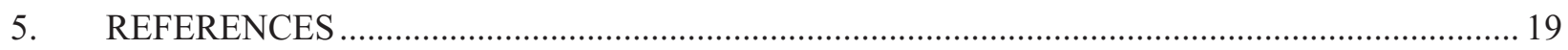

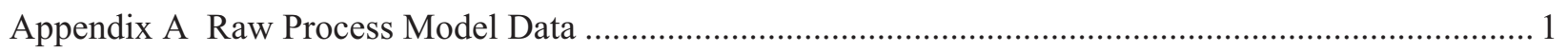




\section{FIGURES}

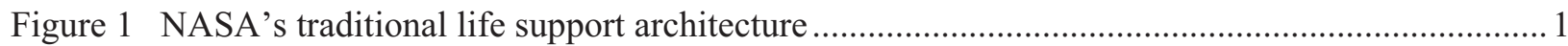

Figure 2 Proposed life support architecture with methanol formation..................................................... 1

Figure 3 Proposed life support architecture with $\mathrm{CO}$ and $\mathrm{H}_{2}$ separation ..........................................2

Figure 4 Process flow diagram external to the electrolysis module ...................................................... 6

Figure 5 Process flow diagram of electrolysis module ....................................................................... 7

Figure 6 Process flow diagram of Methanol process with co-electrolysis............................................ 10

Figure 7 Process flow diagram of co-electrolysis with pressure swing adsorption ............................... 11

Figure 8 Comparison of power required to process $1 \mathrm{~kg} /$ day of $\mathrm{CO}_{2}$ between methanol synthesis

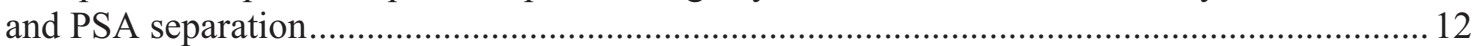

Figure 9 Specific power to process $1 \mathrm{~kg}$ of $\mathrm{CO}_{2}$ as a function of the syngas ratio ................................ 13

Figure 10 Mass balance of co-electrolysis combined with methanol production .................................... 14

Figure 11 Mass balance of co-electrolysis combined with PSA separation............................................ 14

Figure 12 Comparison of methanol, light gas, distilled water, and oxygen flow with inlet flows. ............ 15

Figure 13 Light gas composition as a function of syngas ratio............................................................ 15

Figure 14 Performance ratios and carbon dioxide fraction for methanol production as a function

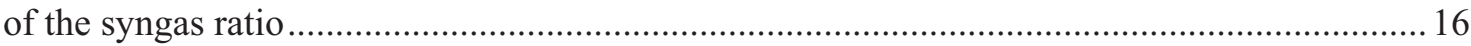

Figure 15 Mass flows of purge gas, hydrogen and oxygen flow rates compared to inlet water and

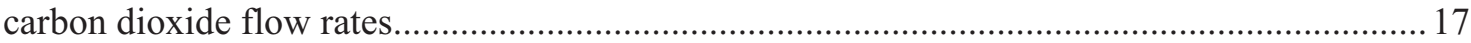

Figure 16 Composition of hydrogen stream as a function of syngas ratio............................................. 17

Figure 17 Composition of purge gas stream as a function of syngas ratio ............................................. 18 


\section{Mathematical Analysis of a Novel Approach to Maximize Waste Recovery in a Life Support System}

\section{INTRODUCTION}

The carbon dioxide, $\mathrm{CO}_{2}$ and steam, $\mathrm{H}_{2} \mathrm{O}$ electrolyzer is an alternative to NASA's currently considered Sabatier reactor and water electrolyzer for $\mathrm{CO}_{2}$ reduction and oxygen generation, respectively.

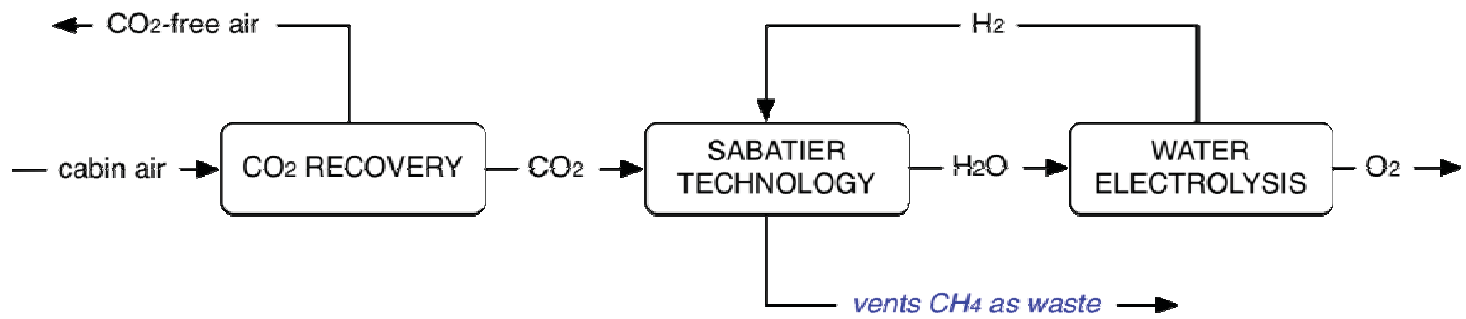

Figure 1 NASA's traditional life support architecture

In a potential, closed-loop life support architecture, the co-electrolysis unit will receive compressed $\mathrm{CO}_{2}$ from an adsorption compressor, which is part of its atmosphere revitalization system (ARS), to generate oxygen and fuel. NASA's traditional closed-loop life support system design has separate systems for chemical reduction of $\mathrm{CO}_{2}(\mathrm{CDRe})$ and water electrolysis to reclaim $\mathrm{O}_{2}$ from metabolic $\mathrm{CO}_{2}$. Coelectrolysis combines the $\mathrm{CO}_{2}$ reduction and oxygen generation processes efficiently into a single hardware, reducing overall system mass. Syngas, the byproduct of co-electrolysis, can be used as a raw material for production of synthetic fuels. If syngas is used to produce liquid products, one needs to consider the increase in system mass due to the addition of the synthetic fuel process.

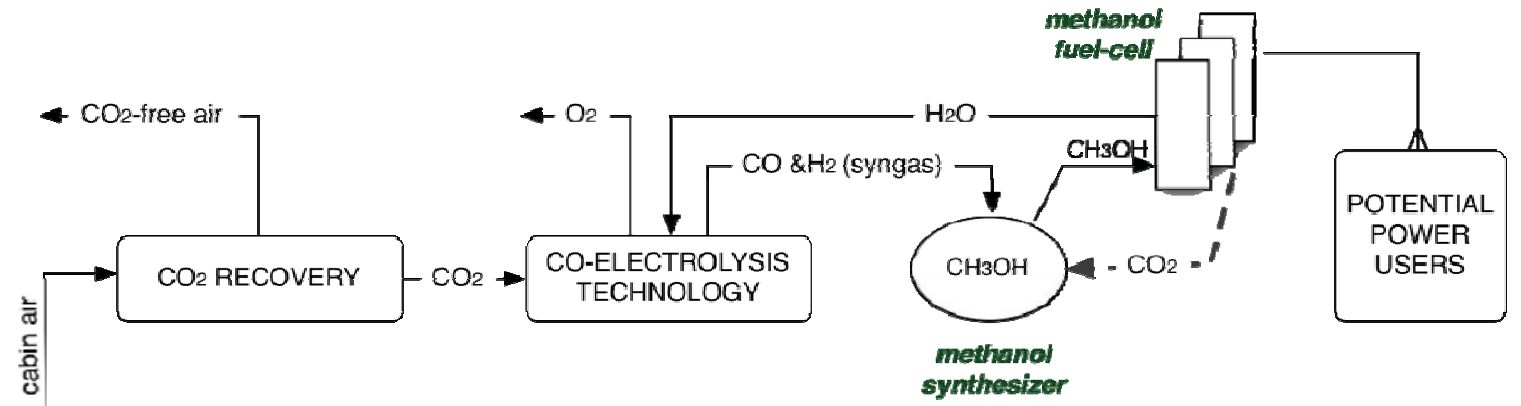

Figure 2 Proposed life support architecture with methanol formation

Syngas is a mixture of carbon monoxide $(\mathrm{CO})$ and hydrogen $\left(\mathrm{H}_{2}\right)$. Loop closure can be maximized by converting syngas to storage-efficient liquid fuels, or by separating $\mathrm{H}_{2}$ from $\mathrm{CO}$ for reuse. This investigation will compare these two approaches to syngas utilization with methanol as the target synthetic fuel. Methanol, $\mathrm{H}_{2}$, and $\mathrm{CO}$ have fuel value and their products of combustion, $\mathrm{CO}_{2}$ and water, can be captured and recycled to complete loop closure. 


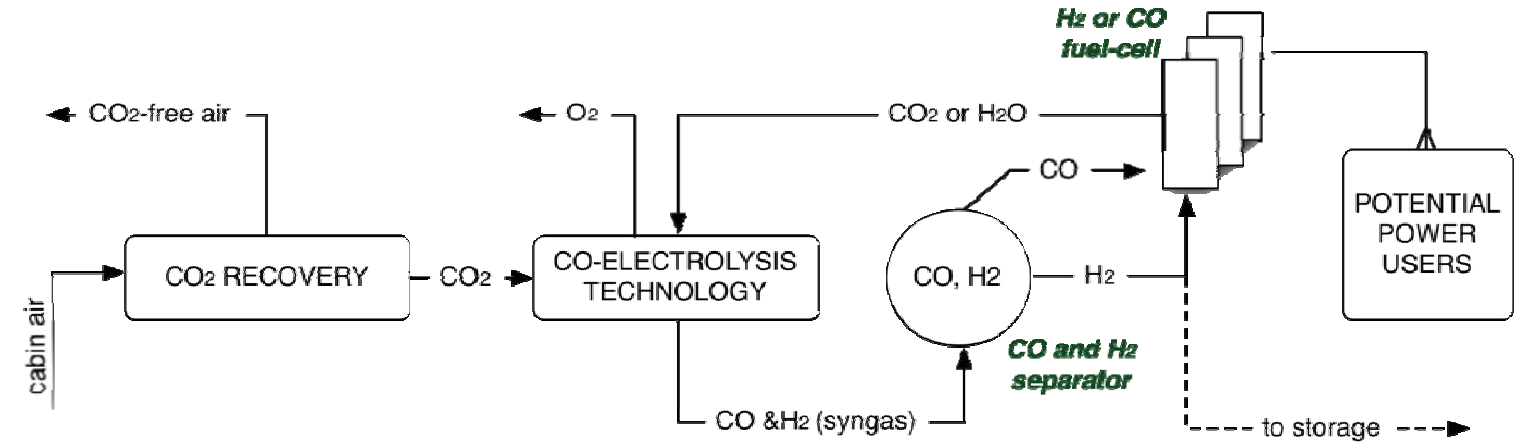

Figure 3 Proposed life support architecture with $\mathrm{CO}$ and $\mathrm{H}_{2}$ separation

\section{PROCESS MODELS}

The process models for this mathematical analysis were developed using Honeywell's UniSim Design R390.1 (Build 15107) process modeling software. UniSim Design software inherently ensures mass and energy balances across all components and it includes thermodynamic data for all chemical species. The software realistically models components such as pumps, compressors, turbines, and heat exchangers. It also models chemical equilibrium reactions. The models described in this report were developed assuming steady state operation with chemical equilibrium reactions.

\subsection{Co-Electrolysis Integrated Process Models}

\subsubsection{1-D Co-Electrolysis Model}

Co-electrolysis is a process by which both steam and carbon dioxide may be electrolyzed in a high temperature $\sim 800^{\circ} \mathrm{C}$ process using solid oxide electrolysis cells. A one-dimensional chemical equilibrium model has been developed for analysis of steam/carbon dioxide co-electrolysis. This model can be used to predict open-cell and operating potentials, electrolyzer outlet compositions, and outlet temperatures for specified inlet gas flow rates, current densities, cell area-specific resistance, and thermal boundary conditions.

The Nernst potential for the co-electrolysis system can be calculated as a function of temperature using the Nernst equation for either steam-hydrogen or for $\mathrm{CO}_{2}-\mathrm{CO}$, provided the equilibrium composition of the components is used in the evaluating the equation. Therefore, prior to applying the Nernst equation, the electrolyzer-inlet equilibrium composition must be determined at the operating temperature. The chemical equilibrium co-electrolysis model determines the equilibrium composition of the system as follows.

The overall water gas shift reaction that occurs during heat-up from the cold unmixed inlet conditions to the hot mixed pre-electrolyzer state can be represented as:

$\mathrm{y}_{0, \mathrm{CO}} \mathrm{CO}+\mathrm{y}_{0, \mathrm{CO} 2} \mathrm{CO}_{2}+\mathrm{y}_{0, \mathrm{H} 2} \mathrm{H}_{2}+\mathrm{y}_{0, \mathrm{H} 2 \mathrm{O}} \mathrm{H}_{2} \mathrm{O} \rightarrow \mathrm{y}_{1, \mathrm{CO}} \mathrm{CO}+\mathrm{y}_{1, \mathrm{CO} 2} \mathrm{CO}_{2}+\mathrm{y}_{1, \mathrm{H} 2} \mathrm{H}_{2}+\mathrm{y}_{1, \mathrm{H} 2 \mathrm{O}} \mathrm{H}_{2} \mathrm{O}$

where the $y_{0, j}$ values represent the cold inlet mole fractions of $\mathrm{CO}, \mathrm{CO}_{2}, \mathrm{H}_{2}$, and $\mathrm{H}_{2} \mathrm{O}$, respectively, that are known from specification of the individual component inlet gas flow rates. The unknown equilibrium mole fractions of the four species at the electrolyzer temperature, prior to electrolysis, are represented by 
the $y_{1, j}$ values. There are three governing chemical balance equations for carbon, hydrogen, and oxygen corresponding to Eqn. (1):

$$
\begin{gathered}
\mathrm{y}_{0, \mathrm{CO}}+\mathrm{y}_{0, \mathrm{CO} 2}=\mathrm{y}_{1, \mathrm{CO}}+\mathrm{y}_{1, \mathrm{CO} 2} \\
2 \mathrm{y}_{0, \mathrm{H} 2}+2 \mathrm{y}_{0, \mathrm{H} 2 \mathrm{O}}=2 \mathrm{y}_{1, \mathrm{H} 2}+2 \mathrm{y}_{1, \mathrm{H} 2 \mathrm{O}} \\
\mathrm{y}_{0, \mathrm{CO}}+2 \mathrm{y}_{0, \mathrm{CO} 2}+\mathrm{y}_{0, \mathrm{H} 2 \mathrm{O}}=\mathrm{y}_{1, \mathrm{CO}}+2 \mathrm{y}_{1, \mathrm{CO} 2}+\mathrm{y}_{1, \mathrm{H} 2 \mathrm{O}}
\end{gathered}
$$

The final equation invokes the equilibrium constant for the shift reaction:

$$
K_{e q}(T)=\frac{y_{1, C O 2} y_{1, H 2}}{y_{1, C O} y_{1, H 2 O}}
$$

completing a system of four equations and four unknowns. Simultaneous solution of this system of equations yields the hot inlet composition.

Once the hot inlet equilibrium composition is determined, the open-cell Nernst potential can be calculated from:

$$
V_{N}=\frac{-\Delta G_{f, H_{2} O}(T)}{2 F}-\frac{R_{u} T}{2 F} \ln \left[\left(\frac{y_{1, H 2 O}}{y_{1, H 2} y_{O 2}^{1 / 2}}\right)\left(\frac{P}{P_{s t d}}\right)^{-1 / 2}\right]=\frac{-\Delta G_{f, C O_{2}}(T)}{2 F}-\frac{R_{u} T}{2 F} \ln \left[\left(\frac{y_{1, C O 2}}{y_{1, C O} y_{O 2}^{1 / 2}}\right)\left(\frac{P}{P_{s t d}}\right)^{-1 / 2}\right]
$$

where $y_{\mathrm{O}_{2}}$ is the mole fraction of oxygen on the air-sweep side of the cells $\left(y_{\mathrm{O}_{2}} \sim 0.21\right)$. Note that the Nernst equation for either steam-hydrogen or $\mathrm{CO}_{2}-\mathrm{CO}$ yields the same result for the equilibrium system. The electrolyzer outlet composition can be determined similarly, after accounting for electrochemical reduction of the system. The chemical balance equation for oxygen must be modified to account for oxygen removal from the $\mathrm{CO}_{2}$ /steam mixture. Accordingly, the oxygen balance equation becomes:

$$
\mathrm{y}_{1, \mathrm{CO}}+2 \mathrm{y}_{1, \mathrm{CO} 2}+\mathrm{y}_{1, \mathrm{H} 2 \mathrm{O}}=\mathrm{y}_{2, \mathrm{CO}}+2 \mathrm{y}_{2, \mathrm{CO} 2}+\mathrm{y}_{2, \mathrm{H} 2 \mathrm{O}}+\Delta \mathrm{n}_{\mathrm{O}}
$$

where $\Delta n_{O}$ is the relative molar rate of monatomic oxygen removal from the $\mathrm{CO}_{2} /$ steam mixture given by:

$$
\Delta n_{O}=\frac{I_{e}}{2 F \dot{N}_{T o t}}
$$

In this equation, $\mathrm{I}_{\mathrm{e}}$ is the total ionic current, $\mathrm{I}_{\mathrm{e}}=\mathrm{i} \cdot \mathrm{A}_{\text {cell }} \mathrm{N}_{\text {cells, }}, \dot{N}_{\text {Tot }}$ is the total molar flow rate on the $\mathrm{CO}_{2}$ /steam side, including any inert gas flows, and $\mathrm{F}$ is the Faraday number. Finally, using the modified oxygen balance equation, the post-electrolyzer equilibrium composition (state 2) can be determined as a function of temperature from simultaneous solution of three chemical balance equations and the equilibrium constant equation.

In general, the electrolyzer outlet temperature is unknown. The magnitude of any temperature change associated with electrolyzer operation depends both on the operating conditions (operating voltage, inlet composition, gas flow rates, etc.) and on the thermal boundary condition. If the electrolyzer operating voltage is below the thermal neutral voltage, the endothermic reaction heat requirement dominates and the 
stack will tend to cool off. If the operating voltage is above thermal neutral, ohmic heating dominates and the stack tends to heat up.

If adiabatic electrolyzer operation is assumed, the outlet temperature can be determined as a function of operating voltage from simultaneous solution of the energy equation and the chemical balance and equilibrium constant equations. Alternately, if isothermal operation is assumed, the outlet composition can be determined independently of the energy equation and the heat required to maintain isothermal operation can be calculated as a function of operating voltage.

For pure-steam or pure- $\mathrm{CO}_{2}$ electrolysis, the thermal neutral voltage is given by

$$
V_{t n, j}(T)=\frac{\Delta H_{R, j}(T)}{2 F}
$$

where $\Delta H_{R, j}(T)$ is the enthalpy of reaction for electrolysis of pure component $\mathrm{j}\left(\mathrm{H}_{2} \mathrm{O}\right.$ or $\left.\mathrm{CO}_{2}\right)$ at temperature $T$. At $800^{\circ} \mathrm{C}, V_{t n}, \mathrm{H} 2 \mathrm{O}=1.29 \mathrm{~V}$ and $V_{t n}, \mathrm{CO}_{2}=1.46 \mathrm{~V}$. For co-electrolysis, the thermal neutral voltage can range anywhere between the respective pure-component values, depending on inlet composition, oxygen utilization, and temperature (via the equilibrium constant, $K_{e q}(T)$ ). There is no simple explicit relation for the multi-component thermal neutral voltage. In general, the thermal neutral voltage for co-electrolysis will be closer to the pure-steam value if the inlet composition is dominated by steam and hydrogen. Conversely, if the inlet composition is dominated by $\mathrm{CO}_{2}$ and $\mathrm{CO}$, the coelectrolysis thermal neutral voltage will be closer to the pure- $\mathrm{CO}_{2}$ value. At an operating temperature of $800^{\circ} \mathrm{C}$, with syngas-production-relevant inlet compositions for co-electrolysis (i.e., $\sim 2$-to-1

steam/hydrogen vs $\mathrm{CO}_{2}$ ), a thermal neutral voltage value of $\sim 1.34 \mathrm{~V}$ is typical. The energy equation for the co-electrolysis process can be written as:

$$
\dot{Q}-\dot{W}=\sum_{P} \dot{N}_{i}\left[\Delta H_{f_{i}}^{o}+H_{i}\left(T_{P}\right)-H_{i}^{o}\right]-\sum_{R} \dot{N}_{i}\left[\Delta H_{f_{i}}^{o}+H_{i}\left(T_{R}\right)-H_{i}^{o}\right]
$$

where $\dot{Q}$ is the external heat transfer rate to or from the electrolyzer, $\dot{W}$ is the rate of electrical work supplied to the electrolyzer, $\dot{N}_{i}$ is the molar flow rate of each reactant or product, $\Delta H_{f_{i}}^{o}$ is the standardstate enthalpy of formation of each reactant or product and $H_{i}(T)-H_{i}^{o}$ is the sensible enthalpy for each reactant or product. Applying the energy equation in this form, all reacting and non-reacting species in the inlet and outlet streams are accounted for, including inert gases, process steam, hydrogen (introduced to maintain reducing conditions on the steam/hydrogen electrode), $\mathrm{CO}_{2}$, and any excess unreacted process gases.

In general, determination of the outlet temperature from Eqn. (10) is an iterative process. The heat transferred during the process must first be specified (e.g., zero for the adiabatic case). The temperaturedependent enthalpy values of all species must be available from curve fits or some other database. The cathode-side hot electrolyzer-inlet molar composition and flow rates of steam, hydrogen, $\mathrm{CO}_{2}, \mathrm{CO}$, and any inert carrier gases such as nitrogen (if applicable) have already been determined from specification of the cold inlet flow rates of all components and from Eqns. $(2-6)$. The inlet flow rate of the sweep gas (e.g., air or steam) on the anode side must also be specified. At this point, the total electrolyzer-inlet enthalpy given by the second summation on the right-hand side of Eqn. (10) can be evaluated.

The current density, active cell area, and number of cells are then specified, yielding the total ionic current, $I_{e}$. Care must be taken to insure that the specified inlet gas flow rates and total ionic current are compatible. The minimum required inlet steam and $\mathrm{CO}_{2}$ molar flow rates must satisfy the following constraint: 


$$
\dot{N}_{\mathrm{H}_{2} \mathrm{O}}+\dot{N}_{\mathrm{CO}_{2}} \geq \frac{I_{e}}{2 \mathrm{~F}}
$$

to avoid oxygen starvation. Note that the oxygen contribution from the $\mathrm{CO}_{2}$ is only counted once, since we want to avoid creation of carbon soot, which could foul the cells.

Evaluation of the electrolyzer-outlet total enthalpy, the first summation in Eqn. (10), requires the product temperature, but the product temperature is generally unknown and is determined from solution of the energy equation, so an iterative solution must be applied. The iterative solution process proceeds as follows. Based on a guessed value of electrolyzer outlet temperature, $T_{P}$, and the specified current, the electrolyzer outlet composition can be determined as described previously, allowing for evaluation of the total enthalpy of the products.

The remaining term in the energy equation is the electrical work, which is the product of the per-cell operating voltage and the total ionic current. The operating voltage corresponding to the specified current density is obtained from:

$$
V_{o p}=\bar{V}_{N}+i \times A S R(T)
$$

The stack area-specific resistance, $A S R(T)$, quantifies the loss mechanisms in the operating cell. It must be estimated, based on experimental data or an appropriate model, and specified as a function of temperature. The operating-cell mean Nernst potential, $\overline{V_{N}}$, accounting for the variation of gas composition and temperature across the operating cell, can be obtained from an integrated form of the steam-hydrogen-based (or the $\mathrm{CO}_{2}$-CO-based) Nernst equation:

$$
\begin{aligned}
\bar{V}_{N}\left(T_{P}\right)=\frac{1}{2 F\left(T_{P}-T_{R}\right)\left(y_{2, O_{2}}-y_{1, O_{2}}\right)\left[y_{2, H_{2}}\left(T_{P}\right)-y_{1, H_{2}}\right]} \times \\
\int_{T_{R}}^{T_{P}} \int_{y_{1, O 2}}^{y_{2, O 2}} \int_{y_{1, H 2}}^{y_{2, H 2}\left(T_{P}\right)} \Delta G_{R, H_{2} O}(T)+R_{u} T \ln \left(\frac{1-y_{H_{2}}-y_{0, C O_{2}}-y_{N_{2}}}{y_{H_{2}} y_{O_{2}}^{1 / 2}}\right) d y_{H_{2}} d y_{O_{2}} d T
\end{aligned}
$$

Note that the variable in this equation is the unknown product temperature, $T_{P}$, which appears both explicitly and implicitly in the upper integration limits. The steam mole fraction has been expressed in the integrand numerator in terms of the hydrogen mole fraction. The mole-fraction subscripts $0,1,2$ again refer to the cold inlet, hot electrolyzer inlet, and the hot electrolyzer outlet states, respectively. Mole fractions at states 0 and 1 are fully defined. The state- 2 mole fractions are based on the specified current density and the guessed value for $T_{P}$.

Once the mean Nernst potential is evaluated based on a guessed value for $T_{P}$, the operating voltage can be determined and the energy equation can be evaluated. The final converged solution for $T_{P}$ must simultaneously satisfy the chemical balance Eqns. $(2,3,7)$, the equilibrium constant Eqn. (2), and the energy Eqn. (10), subject to Eqns. $(12-13)$.

The solution methodology described above can be applied to any specified electrolyzer heat loss or gain. For adiabatic operation, $Q=0$. Alternately, if the heat loss or gain from the operating electrolyzer is known from a separate heat transfer analysis for a given operating point, the value of that heat loss or gain would be used. 
For isothermal electrolyzer operation, once the inlet flow rates, current density, and operating temperature are specified, an iterative solution is not necessary and the triple integral of Eqn. (13) reduces to a double integral with known upper limits of integration. The energy Eqn. (10) can be solved directly for the heat required to maintain isothermal operation at any operating point.

The model allows for accurate determination of co-electrolysis outlet temperature, composition (anode and cathode sides), mean Nernst potential, operating voltage and electrolyzer power based on specified inlet gas flow rates, heat loss or gain, current density, and cell $A S R(T)$. Alternately, for isothermal operation, it allows for determination of outlet composition, mean Nernst potential, operating voltage, electrolyzer power, and the isothermal heat requirement for specified inlet gas flow rates, operating temperature, current density and $A S R(T)$.

\subsubsection{Implementation of Co-Electrolysis Model into UniSim}

Implementation of the model in UniSim was done in a way that took advantage of as many built-in features of the systems-analysis code as possible. Figure 4 provides a process flow diagram (PFD) representing the implementation of the model in UniSim. The user-specified cold inlet process-gas stream enters at the left. This stream is equilibrated at the desired electrolyzer inlet temperature by means of an equilibrium reactor module that supports the shift reaction, Eqn. (14).

$$
\mathrm{CO}_{2}+\mathrm{H}_{2} \leftrightarrow \mathrm{CO}+\mathrm{H}_{2} \mathrm{O} \quad(4.2 \mathrm{e}+4 \mathrm{~kJ} / \mathrm{kgmole})
$$

The hot shifted stream and the heated sweep-gas stream enter the electrolysis module. This electrolysis module was developed previously for pure steam electrolysis. At this level of the model, the user may specify whether the electrolysis process will be isothermal or adiabatic. If the process is isothermal, the temperature of the process outlet stream must be specified, otherwise, the outlet temperature is determined by iteration using an embedded adjust logical (shown as the A within the diamond) until the process heat is zero. Also at this level, an embedded spreadsheet is used to input the electrolysis variables, (i.e. current density, number of cells, cell area, area specific resistance, etc.).

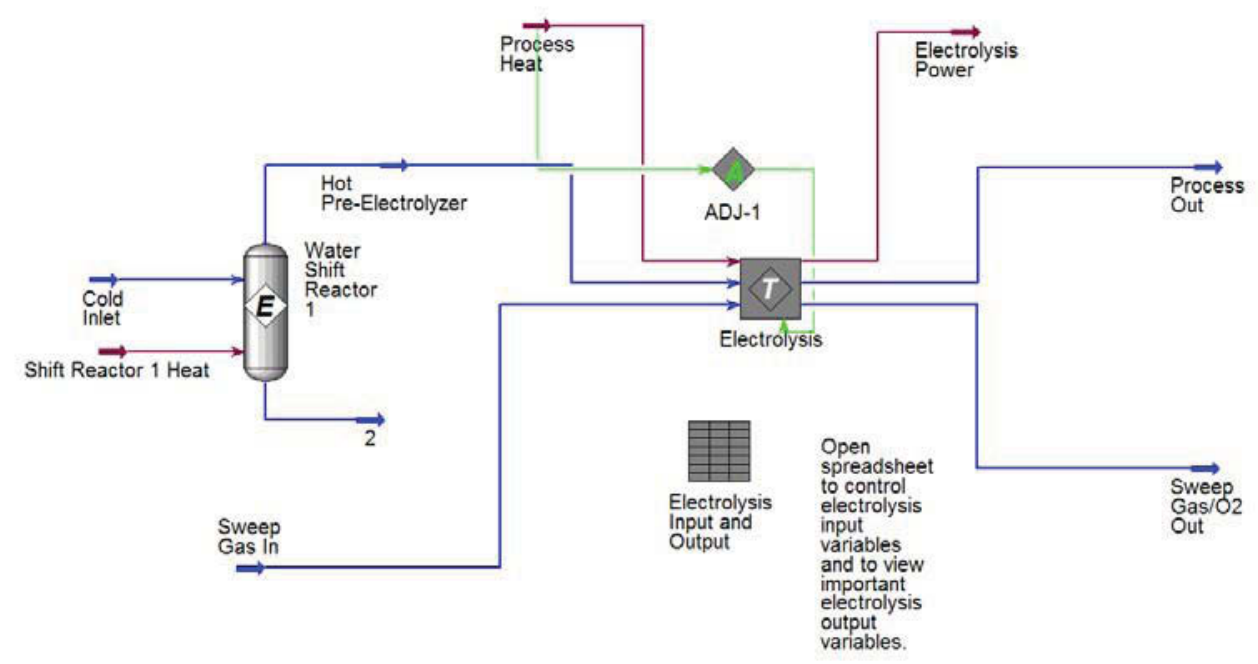

Figure 4 Process flow diagram external to the electrolysis module 


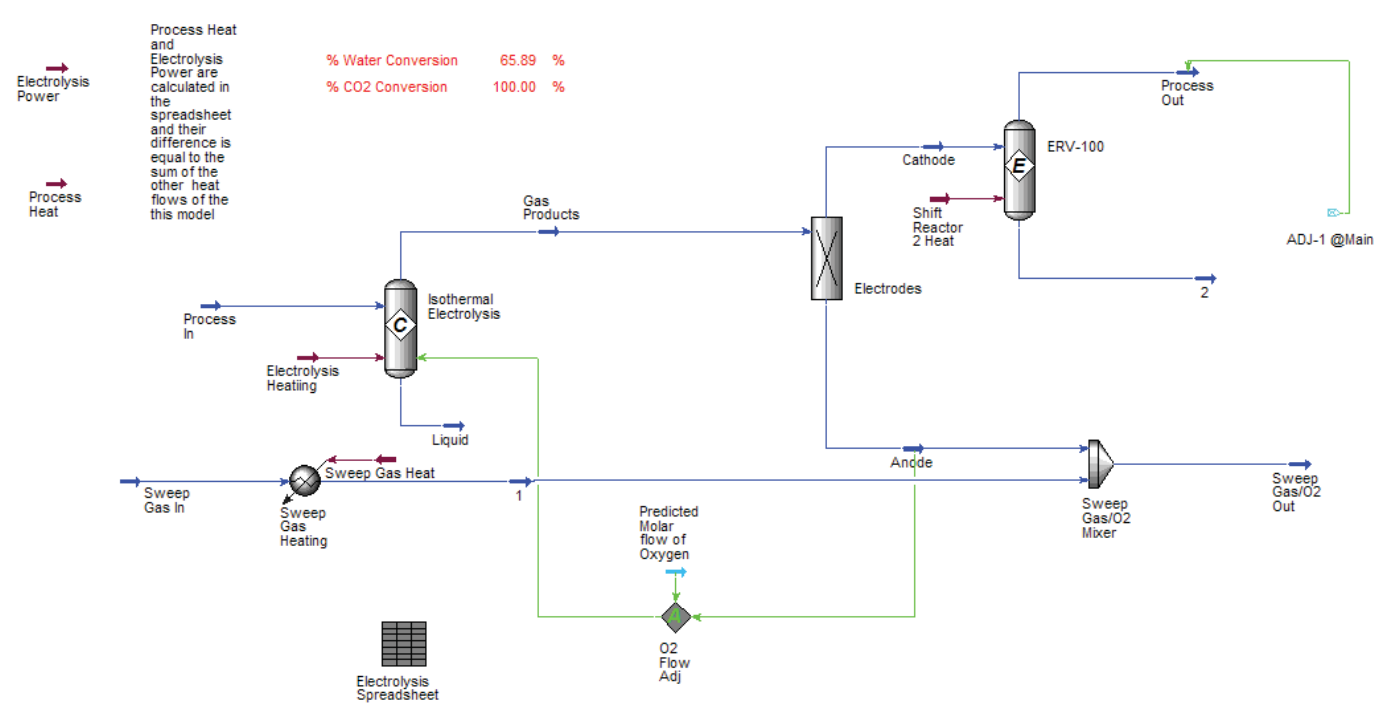

Figure 5 Process flow diagram of electrolysis module

The process flow diagram for the electrolysis module is shown in Figure 5. The hot shifted process stream enters a conversion reactor where the steam and/or carbon dioxide are electrolytically reduced. The conversion reactor unit includes both the steam and carbon dioxide reduction reactions. Based on the percent conversion of the steam and $\mathrm{CO}_{2}$, the reactor will calculate the heat of reaction. The percent conversion of steam and/or $\mathrm{CO}_{2}$ is determined by the amount of oxygen generated using Eqn. (8). This value of the molar flow rate of produced oxygen is stored in a dummy stream. A logical adjust is used to change the percent conversion of steam and carbon dioxide until the oxygen molar flow rate leaving the conversion reactor is the same as the calculated value. The oxygen is split from the rest of the reacted process-gas components by means of a component splitter unit (labeled Electrodes). The split oxygen combines with the sweep gas. The remaining components are passed through a second shift reactor to determine the outlet equilibrium composition.

As previously mentioned, the outlet temperature of both the process and sweep streams are specified but allowed to adjust if adiabatic conditions are desired. An embedded spreadsheet is used to evaluate the mean Nernst potential, Eqn. (13). Assuming a functional relationship for the Gibbs energy of formation, the definite integral was simplified analytically and this simplified version was programmed into the spreadsheet. The UniSim calculation proceeds as follows: having defined the electrolysis variables, the amount of oxygen production is calculated in the spreadsheet using Eqn. (8). Based on an assumed outlet temperature, UniSim proceeds to calculate all the thermodynamics and chemical reactions of the process resulting in outlet compositions for the process and sweep streams. With these now defined, the spreadsheet can calculate the mean Nernst potential by evaluating the simplified triple integral, Eqn. (13). The operating voltage is obtained from Eqn. (12) and the electrolysis power is calculated by multiplying the operating voltage with the total current. UniSim inherently assures that the energy balance, Eqn. (10) is satisfied, which allows the process heat to be calculated by summing the electrolysis power with the total enthalpy differences from the electrolysis process and from the second shift reactor. If the outlet temperature is specified to be the same as the inlet temperature (isothermal operation), the calculation is complete and the process heat is known. If the process is specified to be adiabatic, the outlet temperature is adjusted until the process heat is zero. The process flow sheet automatically assures mass and energy balances. 


\subsection{Methanol Process with Co-electrolysis}

The co-electrolysis process was used to create syngas which then was used as feedstock into a methanol production process. The process flow diagram of the combined processes is shown in Figure 6. Water and carbon dioxide are mixed with recycled syngas and heated to $800^{\circ} \mathrm{C}$ though heat recuperation and direct heating. The direct heating in this analysis is assumed to be from electric heaters. At coelectrolysis temperatures $\sim 800^{\circ} \mathrm{C}$, the stream composition will shift according to the reverse water gas shift reaction, Eq. (14). As discussed in the previous section, the water and carbon dioxide are electrolyzed to produce hydrogen and carbon monoxide on the cathode side of the electrodes and oxygen on the anode side. Both hot product streams are cooled using the recuperating heat exchangers. A portion of the syngas produced is mixed with the incoming water and carbon dioxide to create reducing conditions at the electrolysis electrodes. Most of the water in the sygas is removed and recycled using a water knock out tank. The co-electrolysis process is running at near atmospheric conditions, $\sim 20$ psia. The syngas must be compressed to methanol process pressures of $\sim 1000$ psia by way of a multistage compressor with intercooling. Recycle gas from the methanol process, primarily hydrogen, combines with the incoming syngas and is further compressed. The syngas is heated using another recuperating heat exchanger within the methanol process. The methanol process is modeled using two different types of chemical reactors. The first reactor is an chemical equilibrium reactor where the reverse water gas shift reaction, Eq. (14), and the methanol reaction occur, Eq. (15).

$$
\mathrm{CO}_{2}+3 \mathrm{H}_{2} \leftrightarrow \mathrm{CH}_{3} \mathrm{OH}+\mathrm{H}_{2} \mathrm{O} \quad(-4.1 \mathrm{e}+4 \mathrm{~kJ} / \mathrm{kgmole})
$$

The reactions occur at $227^{\circ} \mathrm{C}$ and 1024 psia. The reactions are exothermic and some heat is released. This heat may be used in preheating the incoming water and carbon dioxide just before the co-electrolysis process. The process also produces some dimethyl ether and propanol as by products by way of a stoichiometric conversion reactor using equations 16 and 17.

$$
\begin{aligned}
2 \mathrm{CH}_{3} \mathrm{OH} & \rightarrow \mathrm{C}_{2} \mathrm{H}_{5} \mathrm{OH}+\mathrm{H}_{2} \mathrm{O} \\
3 \mathrm{CH}_{3} \mathrm{OH} & \rightarrow \mathrm{C}_{3} \mathrm{H}_{7} \mathrm{OH}+2 \mathrm{H}_{2} \mathrm{O}
\end{aligned}
$$

With each reaction only $5 \%$ of the methanol is converted resulting in low concentrations in the exiting stream. The stream passes through a condenser to separate the water and methanol from the hydrogen, carbon monoxide and carbon dioxide. Two distillation columns are used to purify the methanol to $99 \%$. Combustion processes close the loop in which both the methanol and the light gases are combusted. The methanol combustion process is a rough simulation of the fuel cell process.

For methanol production, stoichiometric ratios are used to gauge the suitability of the feed gas for methanol production. A few different metrics can be used. The first metric is the molar ratio:

$$
\left(\mathrm{H}_{2}-\mathrm{CO}_{2}\right) /\left(\mathrm{CO}+\mathrm{CO}_{2}\right)
$$

Literature indicates that the optimal value for this metric for methanol synthesis is around 2, [English]. Many technology providers prefer to run slightly higher than 2. A target value for this analysis of 2.1 was selected, [Haldor Topsoe]. 
The second metric is the molar ratio:

$$
\mathrm{H}_{2} /\left(2 \mathrm{CO}+3 \mathrm{CO}_{2}\right)
$$

Literature indicates that the optimal value for this metric for methanol synthesis is 1.05, [Bartholomew]. It is also useful to know the molar syngas ratio, $\mathrm{H}_{2} / \mathrm{CO}$, of the inlet gas. All of these metrics are for the feed gas to the methanol synthesis loop, not the methanol reactor itself. Studies have shown that conversion in the reactor is enhanced by having some $\mathrm{CO}_{2}$ present at the reactor inlet. However, if too much $\mathrm{CO}_{2}$ is present, conversion will be hindered. An upper limit of $4 \mathrm{~mol} \%$ is presented in the literature to maintain good conversion, [Bartholomew]. There are many different reactor configurations and feeds used for methanol synthesis. 


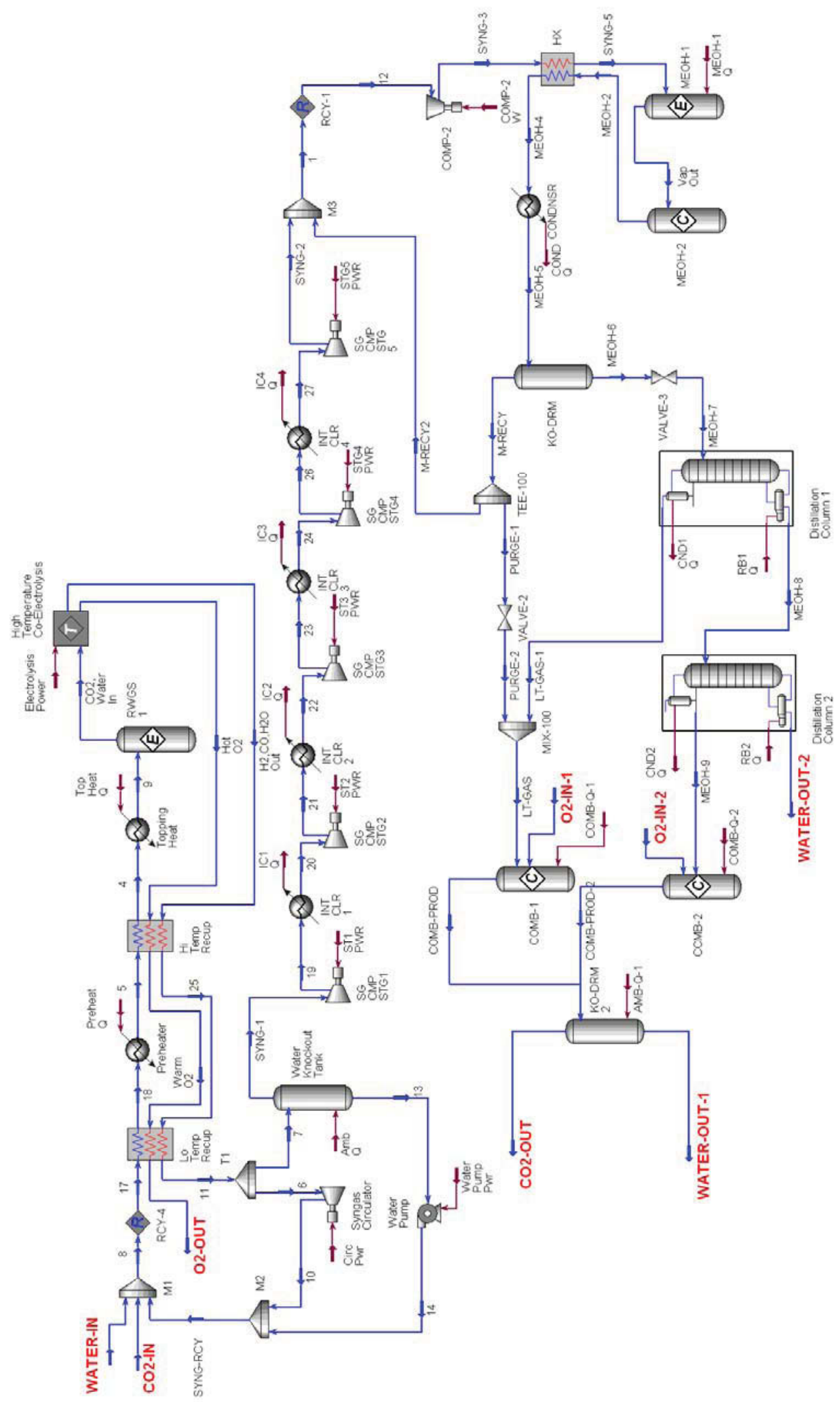

Figure 6 Process flow diagram of Methanol process with co-electrolysis 


\subsection{Co-electrolysis with Pressure Swing Adsorption}

The process model of the co-electrolysis process with pressure swing adsorption is very similar to the previous process except a pressure swing adsorption (PSA) unit replaced the methanol production process. The model for the PSA unit is a very simplified model which uses a splitter block to separate the gases in the PSA unit. PSA is a transient process which relies on the kinetics of the adsorption process. The process model is a steady state model therefore some simplifying assumptions were used to develop a black box type of model. Based on literature about PSA units, the pressure ratio of the inlet stream to the purge gas is typically 4 or greater, [Burr, Kohl, Kuchta]. Therefore, the pressure into the PSA unit was set to 100 psia. Based on this pressure ratio, $85 \%$ of the incoming hydrogen exits as part of the hydrogen stream with $0.03 \%$ of the incoming carbon monoxide, and $0.003 \%$ of the incoming carbon dioxide. The remaining gas exits the splitter block in the purge gas stream. Based on the literature, the power needed to run the PSA process is given by the following function:

Power $(\mathrm{kW})=0.0009858 *$ Inlet Molar Flow Rate (lbmole/hr), [Kuchta].

The outlet temperature of the hydrogen stream is adjusted until the PSA process is adiabatic, ("PSA heat" stream equals zero). As with the previous model, the purge gas and hydrogen stream are combusted.

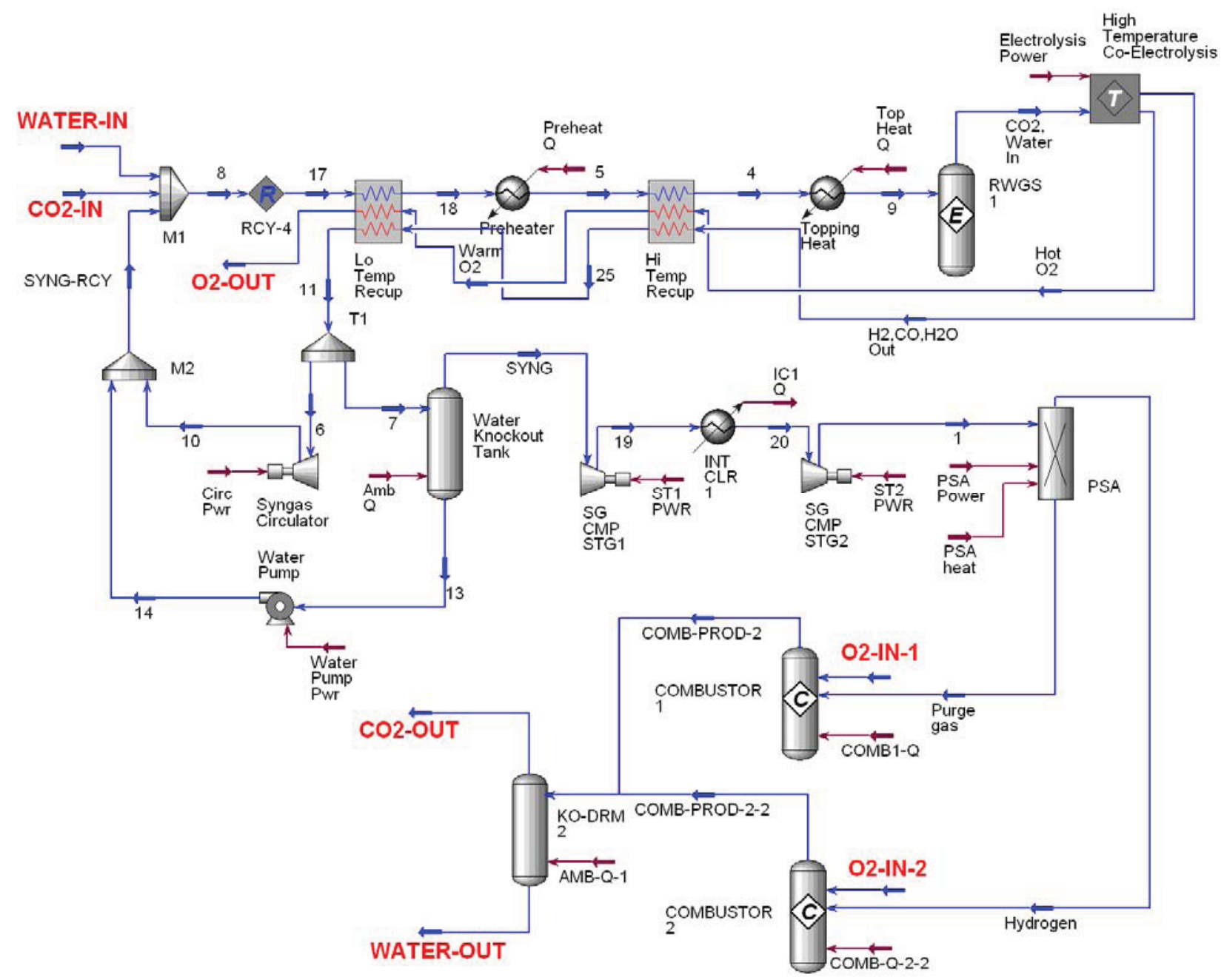

Figure 7 Process flow diagram of co-electrolysis with pressure swing adsorption 


\section{RESULTS}

The scale of the process models was set to $1 \mathrm{~kg}$ /day of carbon dioxide processed to allow for comparison. Figure 8 compares the power output needed to process the carbon dioxide for both the methanol and pressure swing adsorption (PSA) separation processes as a function of the syngas ratio. The power needed for both cases is close. Both cases require more power as the ratio of the hydrogen increases because more input water is needed to supply the hydrogen while the flow rate of the incoming carbon dioxide is constant. The power requirement for the methanol case is slightly less because heat from the methanol reactor is used to raise the temperature of the water and carbon dioxide streams entering the coelectrolysis process where no process heat is available for the PSA cases. The methanol production case is slightly non-linear due to the amount of process heat available for the incoming streams. For the cases where the syngas ratios are 2 and 2.5, there is sufficient heat supplied to the preheater. At higher syngas ratios, some additional electric heat is needed at the preheater.

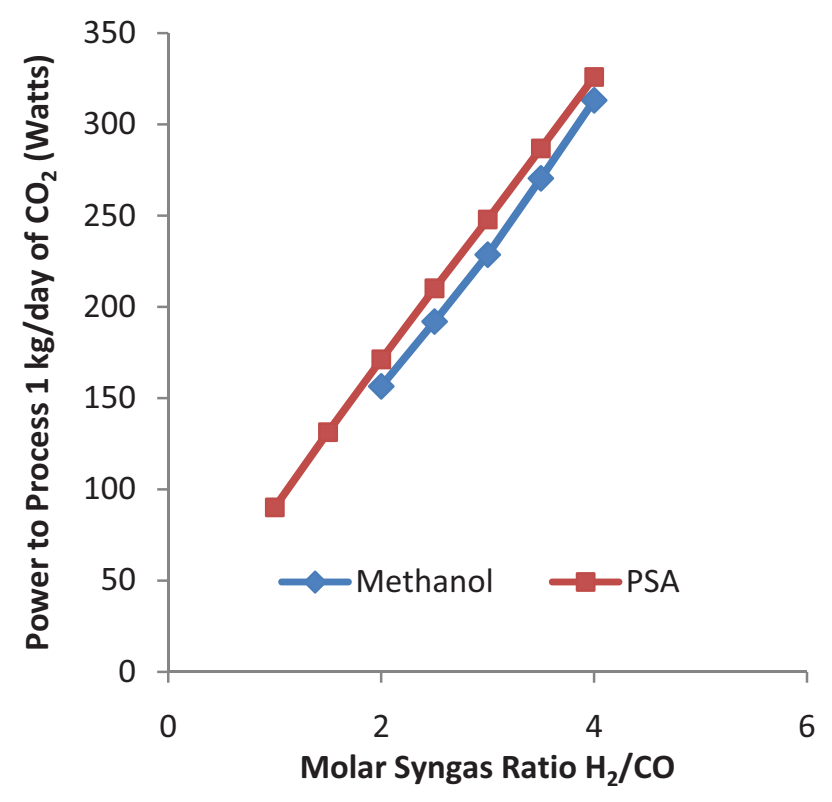

Figure 8 Comparison of power required to process $1 \mathrm{~kg} /$ day of $\mathrm{CO}_{2}$ between methanol synthesis and PSA separation

The specific power can be defined as the power needed to process $1 \mathrm{~kg} /$ day of $\mathrm{CO}_{2}$ divided by the feed water flow rate. The specific power is a measure of the power needed per inlet water flow and can be a measure of the effective use of water to process the $\mathrm{CO}_{2}$. As the syngas ratio increases, the specific power for both processes decreases, see Figure 9. At higher syngas ratios, the curves approach each other and level out indicating that although the power usage per feed water flow may decrease, the addition of feed water does not significantly change the specific power. 


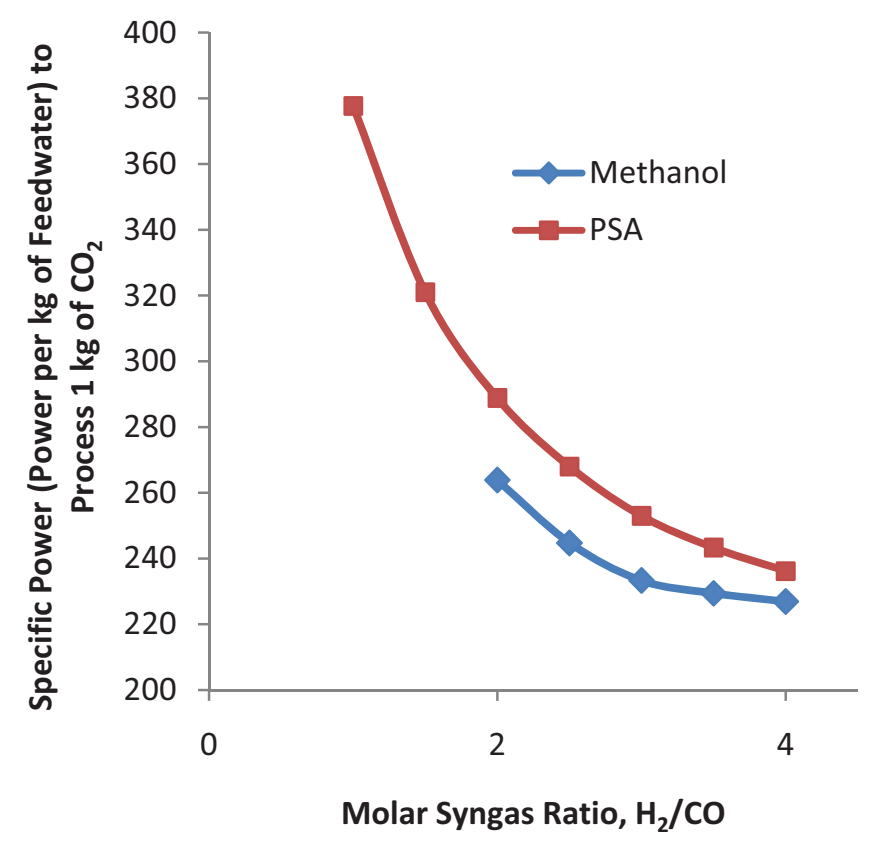

Figure 9 Specific power to process $1 \mathrm{~kg}$ of $\mathrm{CO}_{2}$ as a function of the syngas ratio

Figure 10 shows a mass balance of the co-electrolysis combined with the methanol production process. The figure shows that the water, oxygen, and carbon dioxide inlets and outlets are almost the same. The differences are due to trace amounts of propanol, Di-methyl-ether, and methanol. As expected, as the syngas ratio increases the mass flow of the water must increase to provide the necessary hydrogen resulting in more oxygen as well. Figure 11 is the mass balance of the co-electrolysis process with pressure swing adsorption, PSA. Comparing the co-electrolysis with methanol production against coelectrolysis with PSA separation, the co-electrolysis processes are identical by design. The PSA separation process simply separates the products of the syngas and then combusts them completely. Therefore no complex hydrocarbons are formed and the inlet water, oxygen and carbon dioxide flow rates are identical to the outlet flow as shown in Figure 11. 


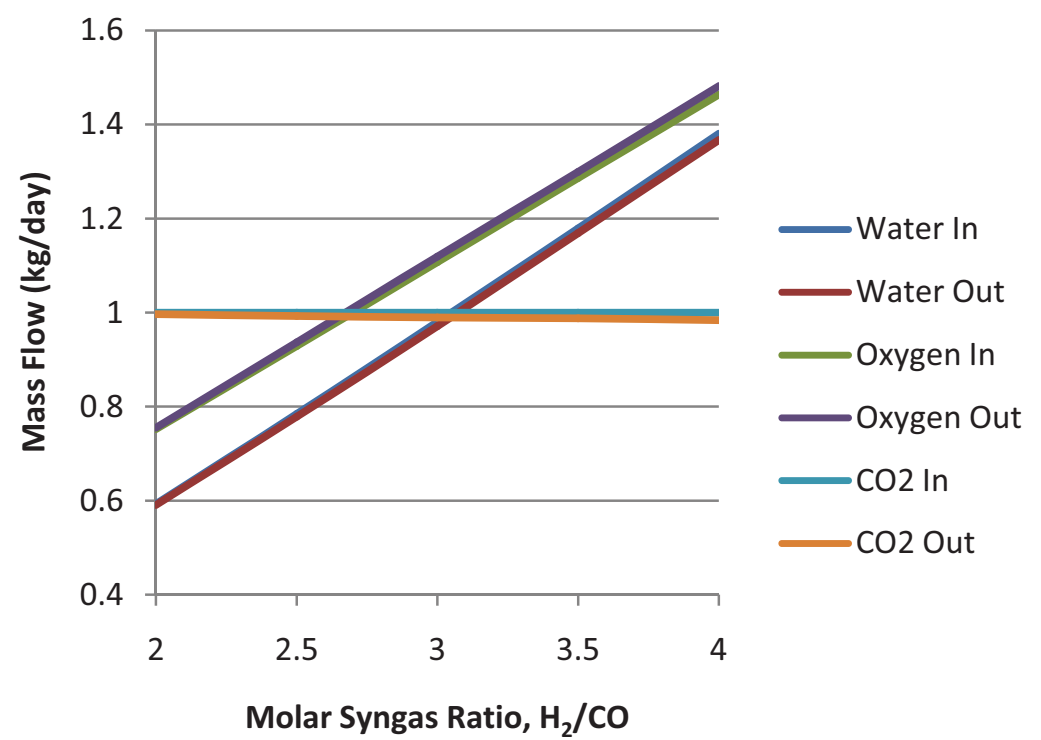

Figure 10 Mass balance of co-electrolysis combined with methanol production

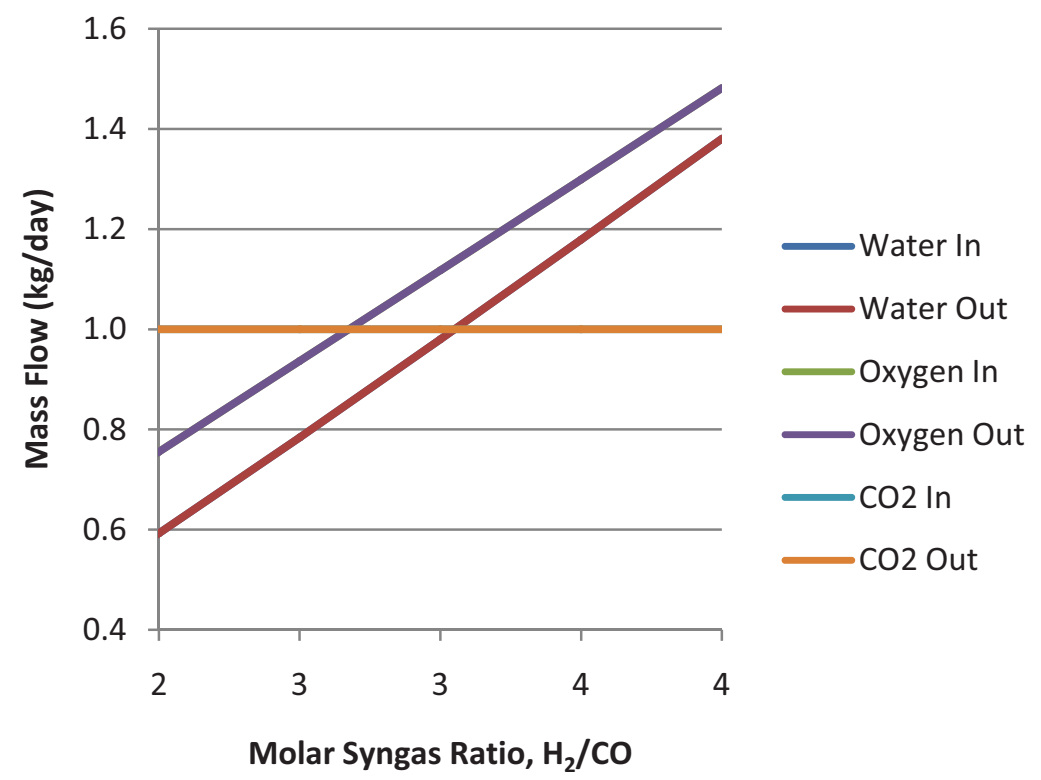

Figure 11 Mass balance of co-electrolysis combined with PSA separation

Figure 12 shows the inlet mass flow rates of water and carbon dioxide, compared to the methanol production, water from the distillation columns, light gas, and oxygen production flow rates. The methanol production and water from the distillation columns flow rates level out at a syngas ratio of 3 .

The light gas flow rate decreases. The methanol purity varies between 99 to $100 \%$ mole with water as the other component. The distilled water varies between 95 to $97 \%$ mole with methanol as the other component. The purity of both is more dependent on column conditions than methanol reactor chemistry and syngas ratio. However the light gas composition is a function of syngas ratio as shown in Figure 13. 


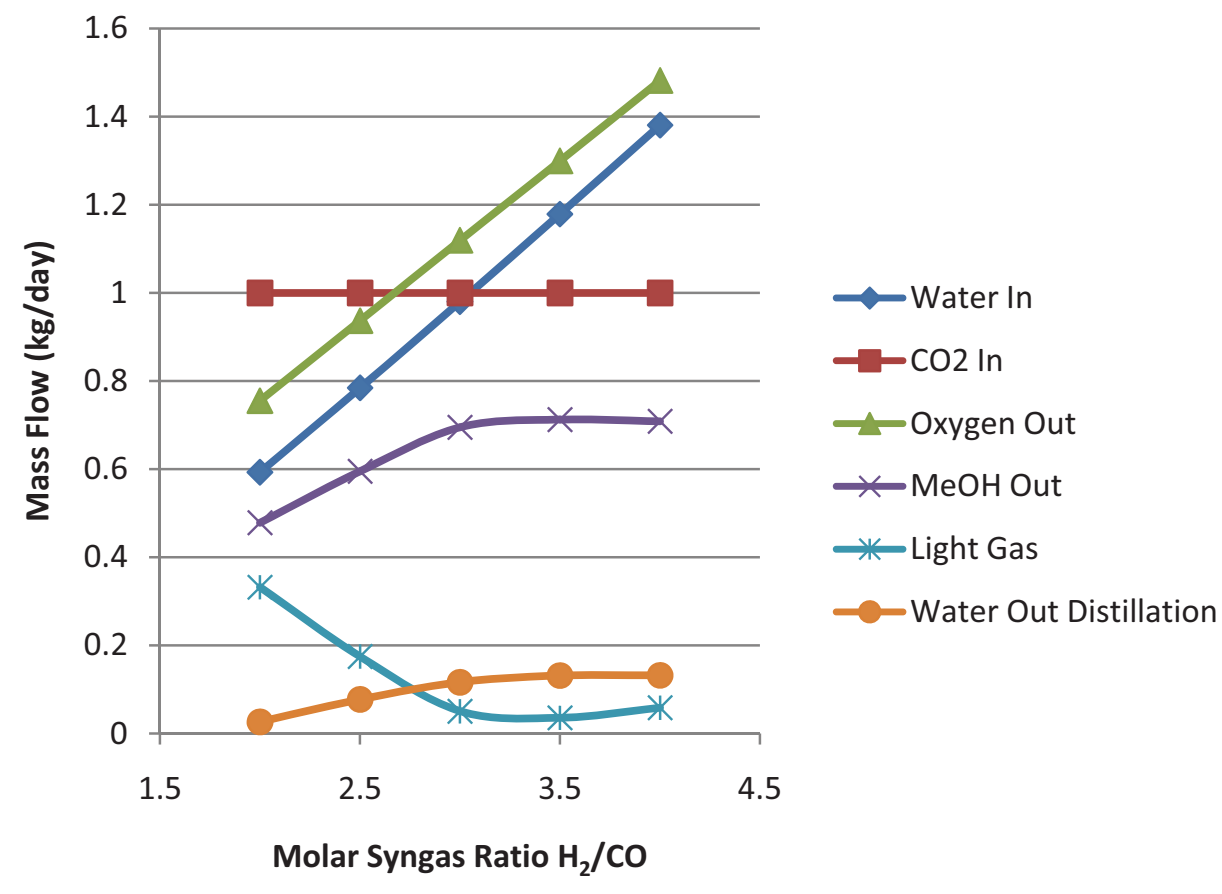

Figure 12 Comparison of methanol, light gas, distilled water, and oxygen flow with inlet flows.

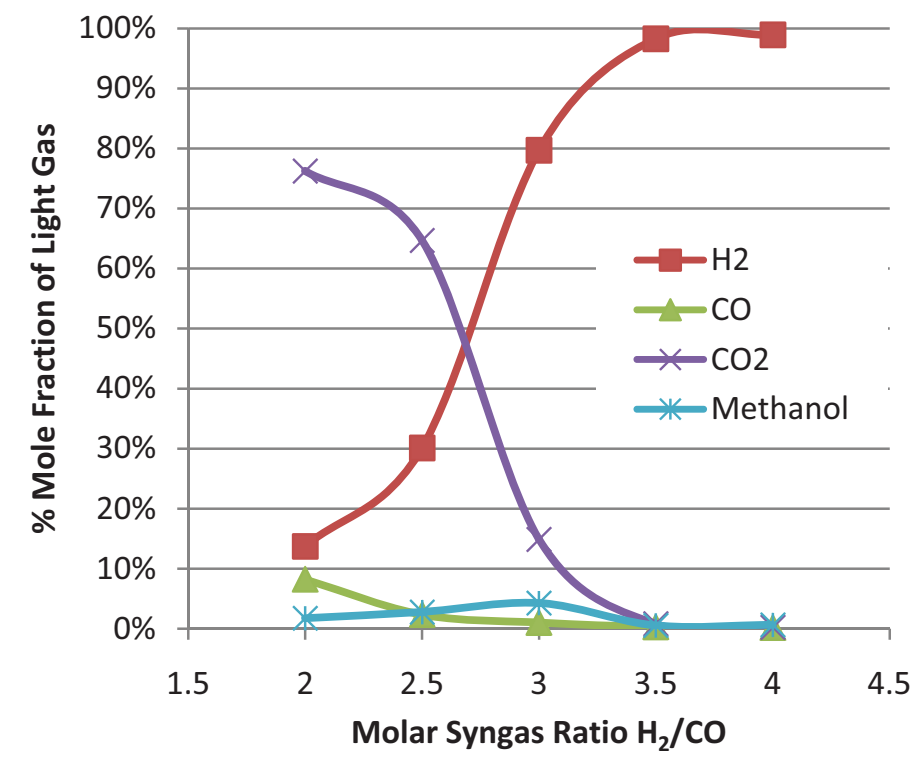

Figure 13 Light gas composition as a function of syngas ratio.

As the syngas ratio increase, the composition of the light gas shifts from carbon dioxide to hydrogen due to the increased amount of hydrogen produced. More of the carbon is made into liquid methanol as opposed to carbon dioxide as the syngas ratio is increased. Figure 14 shows the performance ratios and \% carbon dioxide content for the various syngas ratios and compares them to the optimal performance conditions. At a syngas ratio of around 3, the metrics are met and the ideal carbon dioxide condition is nearly obtained. 


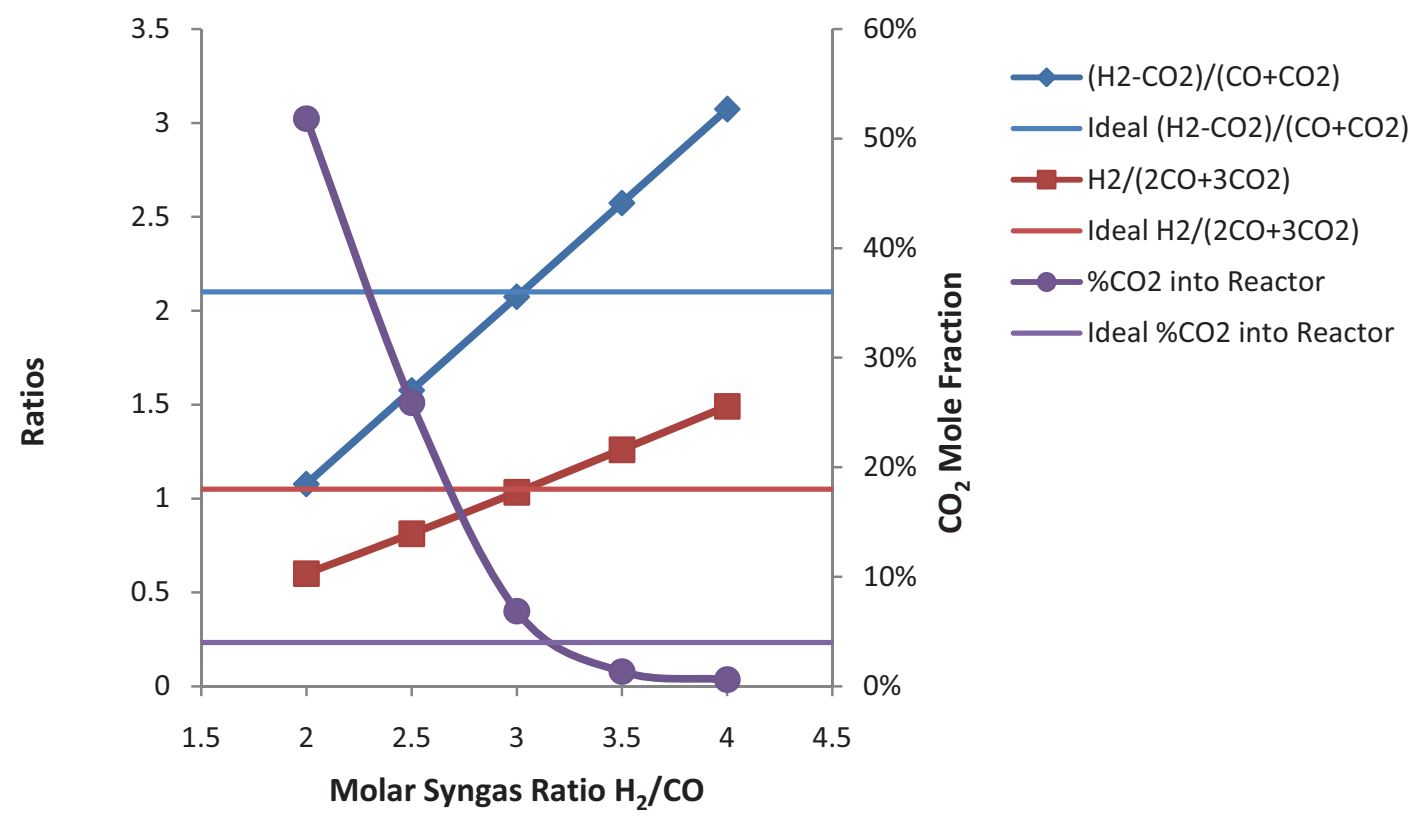

Figure 14 Performance ratios and carbon dioxide fraction for methanol production as a function of the syngas ratio

For the PSA cases, the mass flow rates of hydrogen production, purge gas, and oxygen production are compared to the inlet carbon dioxide and water flow rates, see Figure 15. As the syngas ratio increases, the hydrogen production rate increases and the purge gas flow rate decreases. Figure 16 and Figure 17 show the compositions of the hydrogen and purge gas streams. The hydrogen stream increases from a purity of 99.9 to $99.99 \%$ as the syngas ratio increases. Both the carbon dioxide and carbon monoxide content decrease as this ratio increases because there is increased hydrogen (as water) entering the coelectrolysis process. The carbon dioxide composition of the purge gas decreases rapidly and then begins to level out, as the syngas ratio increases. The carbon monoxide composition increases until the ratio is 2 and then decreases as the ratio increases.

The water content of the purge gas increases linearly, as the ratio increases. The hydrogen composition also increases linearly but at a higher rate. As the hydrogen increases, more of the carbon dioxide is shifted to carbon monoxide due to the water gas shift reaction. However, the hydrogen increases at a faster rate than the carbon dioxide resulting in a higher composition of hydrogen and a decrease in carbon monoxide as the ratio increases 2 . 


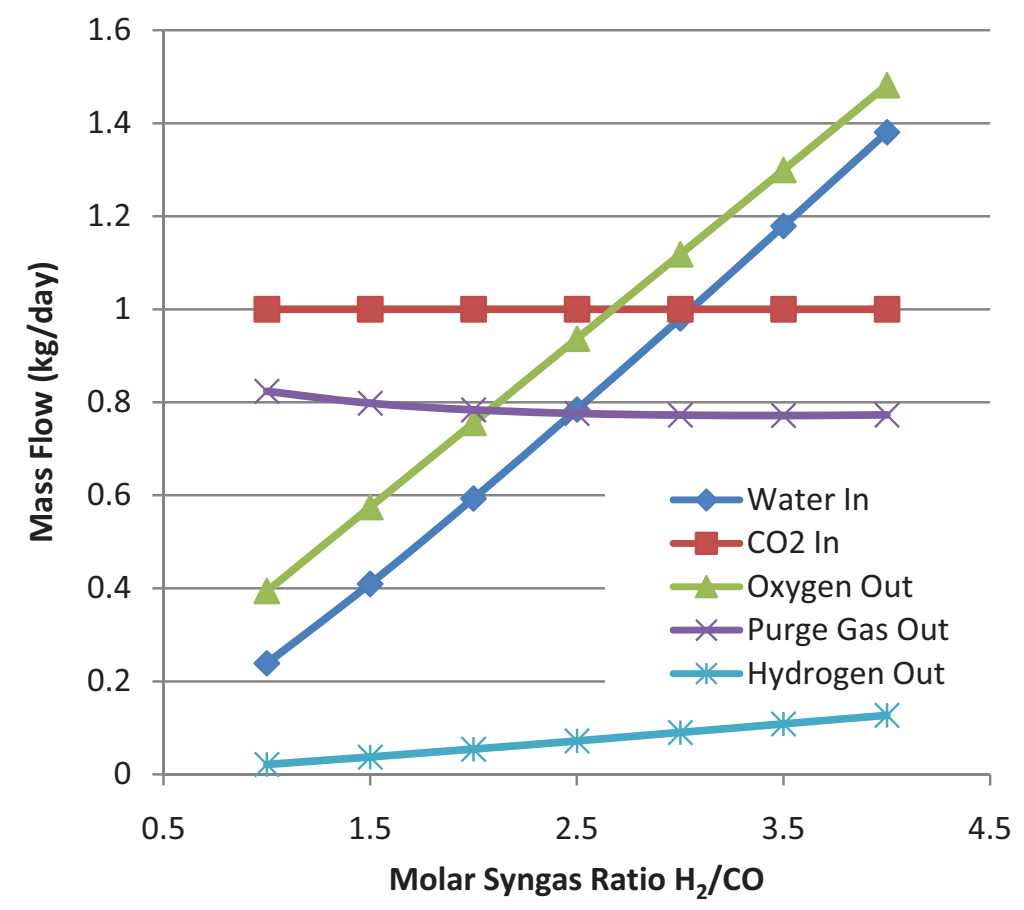

Figure 15 Mass flows of purge gas, hydrogen and oxygen flow rates compared to inlet water and carbon dioxide flow rates

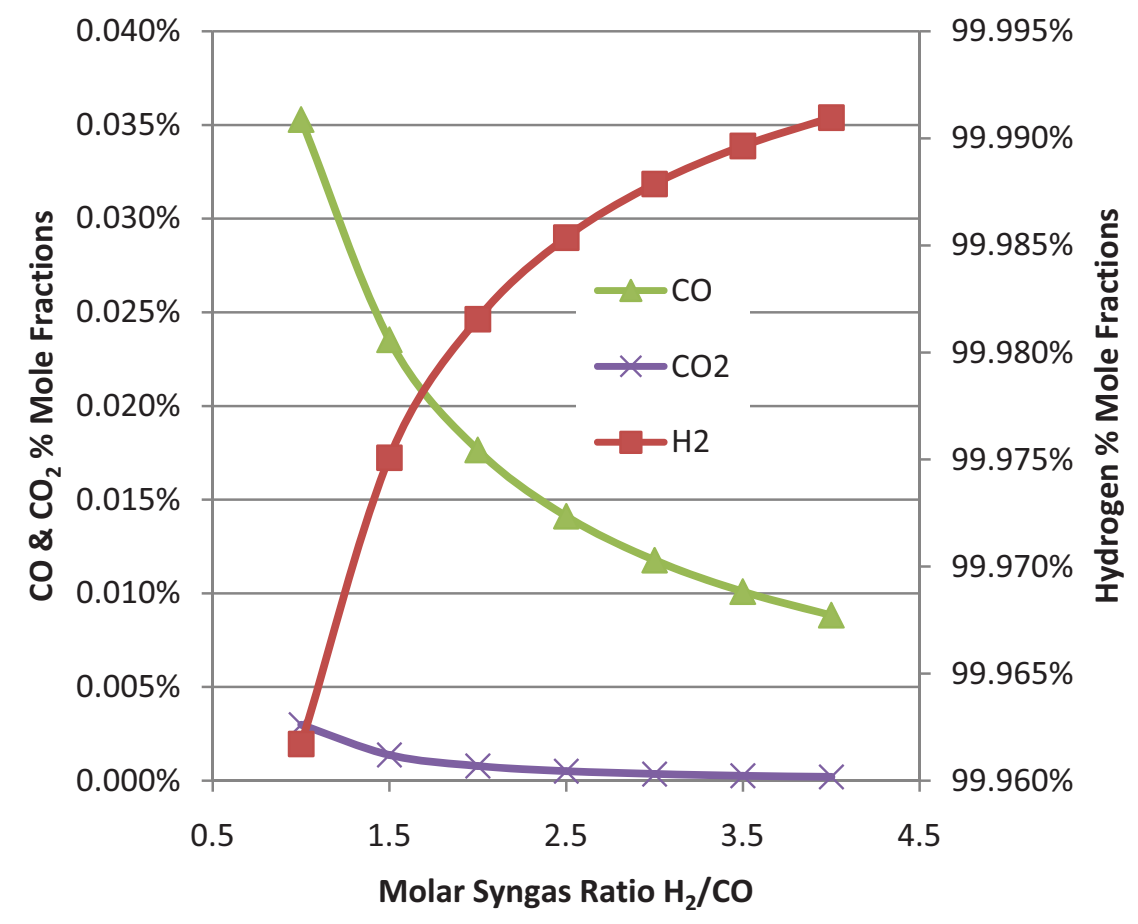

Figure 16 Composition of hydrogen stream as a function of syngas ratio 


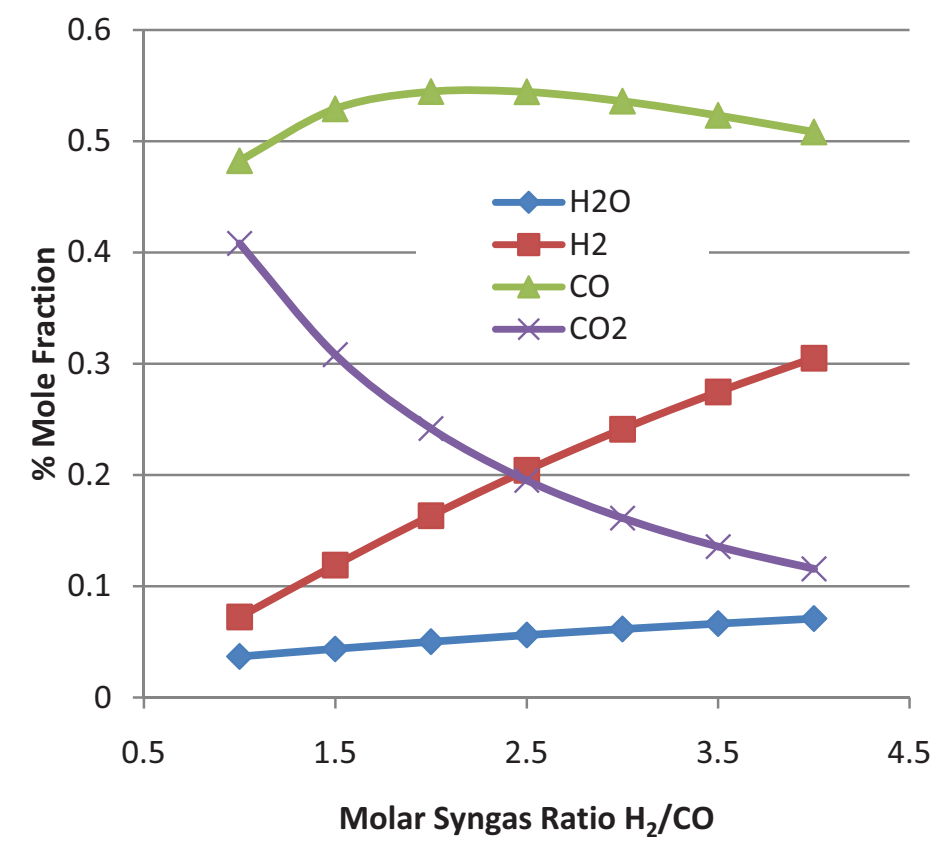

Figure 17 Composition of purge gas stream as a function of syngas ratio

\section{Conclusions and Recommendations}

A comparison was made between two processes for fuel production and combustion which used the syngas product from the co-electrolysis of water and carbon dioxide. In the first process liquid methanol is produced for storage and/or combustion; in the second process hydrogen is separated from syngas and the components are then combusted separately. Power and products were plotted vs. the molar ratio of $\mathrm{H}_{2} / \mathrm{CO}$ in the syngas. The following conclusions are drawn:

- The power required to make methanol is less than the power required to separate the syngas, over all syngas $\mathrm{H}_{2} / \mathrm{CO}$ ratios evaluated, because process heat from methanol production may be used to reduce the power required to heat up the gases feeding the co-electrolysis process.

- If fuels were to be stored for any length of time prior to combustion, pressurization of the separated gases would be necessary, accentuating the advantage of liquid fuel production/storage. Hydrogen gas from the PSA separation process would need to be further compressed to much higher pressures for storage, where no compression is necessary for the liquid methanol fuel.

- Methanol production is optimal at a syngas ratio of 3. This corresponds to an input $\mathrm{H}_{2} \mathrm{O} / \mathrm{CO}_{2}$ ratio of $0.98: 1$ or a molar ratio of 2.4:1. Humans respire/release $\mathrm{H}_{2} \mathrm{O}$ and $\mathrm{CO}_{2}$ in a molar ratio from about 5:1 - 6:1, providing ample water for the syngas ratios evaluated here (up to 4:1). The oxygen output from co-electrolysis can be extracted for human use (but would need to be separated from the purge) or used for combustion.

- At higher syngas ratios (higher water input), the hydrogen product from pressure swing adsorption increases and becomes purer, and the purge gas flow and carbon dioxide content 
decrease. Specific power (power per kg water feed, with constant $1 \mathrm{~kg} \mathrm{CO}_{2}$ feed) for the two models decreases as syngas ratio increases.

- The methanol production process introduces a small amount of light hydrocarbons, propanol and Di-methyl-Ether, in the combustion product $\mathrm{CO}_{2}$ stream. The effect of these contaminants on the co-electrolysis system is unknown. If returned to the space cabin, the trace contaminant control system would have to remove them.

The following recommendations should be considered:

- With co-electrolysis, it is theoretically possible to revitalize the atmosphere of a space cabin and recover oxygen for human metabolic use, simultaneously providing fuel/energy for transportation or other crew needs. Additional oxygen is needed to burn the fuel. If the combustion products can be captured and used for fuel production again, power/fuel needs can be nearly self-sustaining.

- From a power perspective, methanol production is preferable to separation of syngas. Optimal production of methanol should be at a syngas ratio of 3 .

- The co-electrolysis process produces the desired syngas ratio if fed the appropriate ratio of $\mathrm{H}_{2} \mathrm{O} / \mathrm{CO}_{2}$. The desired syngas ratio can be easily obtained using co-electrolysis by adjusting the inlet flows of $\mathrm{CO}_{2}$ and $\mathrm{H}_{2} \mathrm{O}$.

- From a purity perspective, separation of gases is preferable to methanol production. In the separation scenario, feed with higher water content produces higher purity hydrogen.

\section{REFERENCES}

Bartholomew, C. H., R. J. Farrauto, 2006, "Methanol Synthesis," Fundamentals of Industrial Catalytic Processes, $2^{\text {nd }}$ Ed., John Wiley \& Sons.

Burr, Barry, Lili Lyddon, Bryan Research and Engineering, "A Comparison of Physical Solvents for Acid Gas Removal", 2008.

English, Alan, Jerry Rovner, John Brown, and Simon Davies, 2005, "Methanol," Kirk-Othmer Encyclopedia of Chemical Technology, Volume 16, John Wiley \& Sons.

Haldor Topsoe, 2009, "Large Scale Methanol Production from Natural Gas," Product Brochure. http://www.topsoe.com/business_areas/methanol/ /media/PDF\%20files/Methanol/Topsoe_large_scal e_methanol_prod_paper.ashx

Kohl, Arthur, Richard Nielsen, 1997, "Hydrogen Purification by Pressure Swing Adsorption (PSA)”, Gas Purification, Gulf Publishing Company, Houston, Texas.

Kuchta, Eugene, UOP Polybed PSA Unit quote to Mike Friedrich of Aker Kvaerner, July 9, 2003, UOP Proposal P3H038 Rev.4 based on report "Commercialization of the Hymelt Gasification Process for Illinois Coal". 
Appendix A

\section{Raw Process Model Data}




$$
\text { A-2 }
$$




\section{Appendix A Raw Process Model Data}

The models of the processes in Appendix A were developed using UniSim Design Version UniSim Design R390.1 (Build 15107) from Honeywell on a desktop computer running Microsoft Windows XP Professional Version 2002 Service Pack 3. 


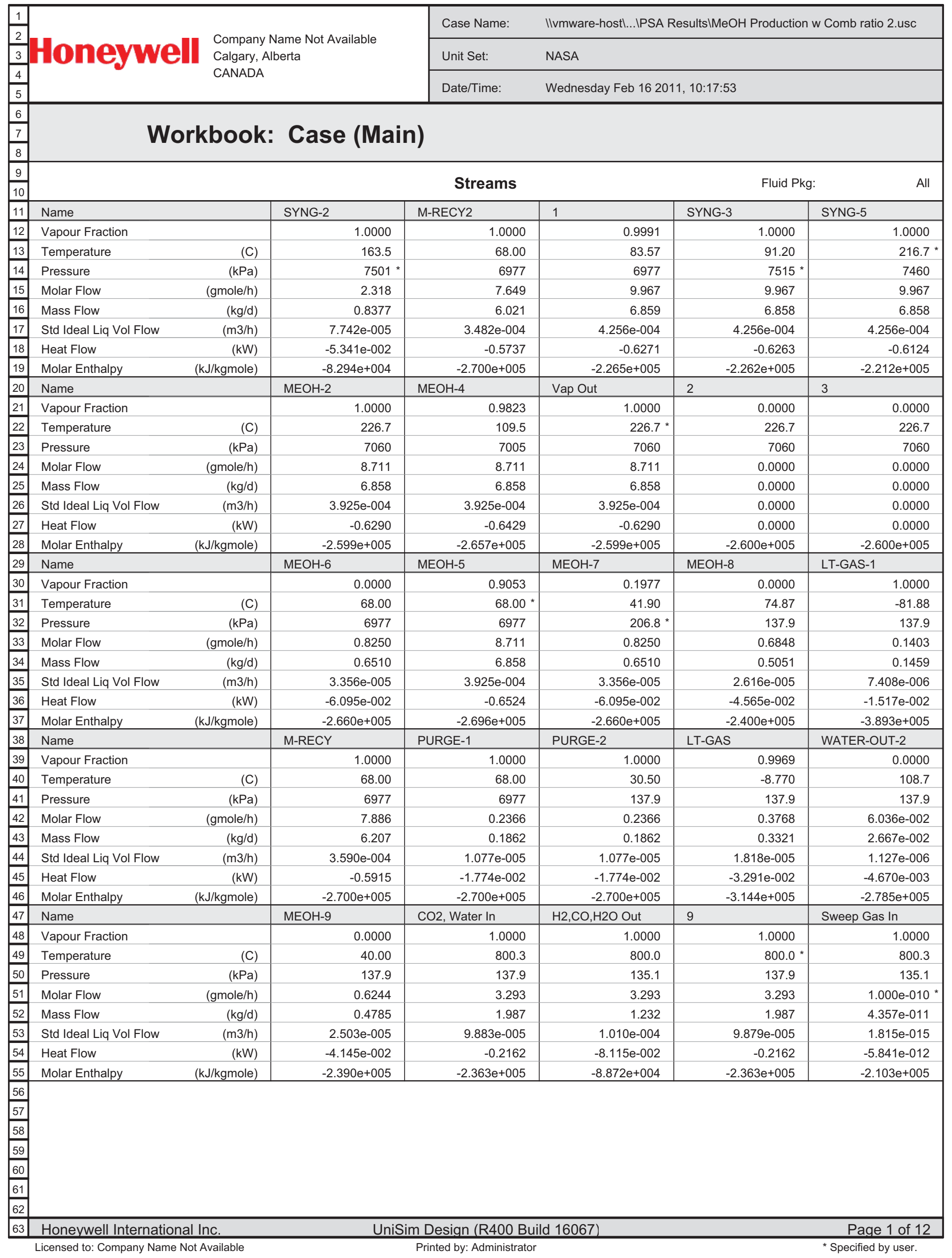




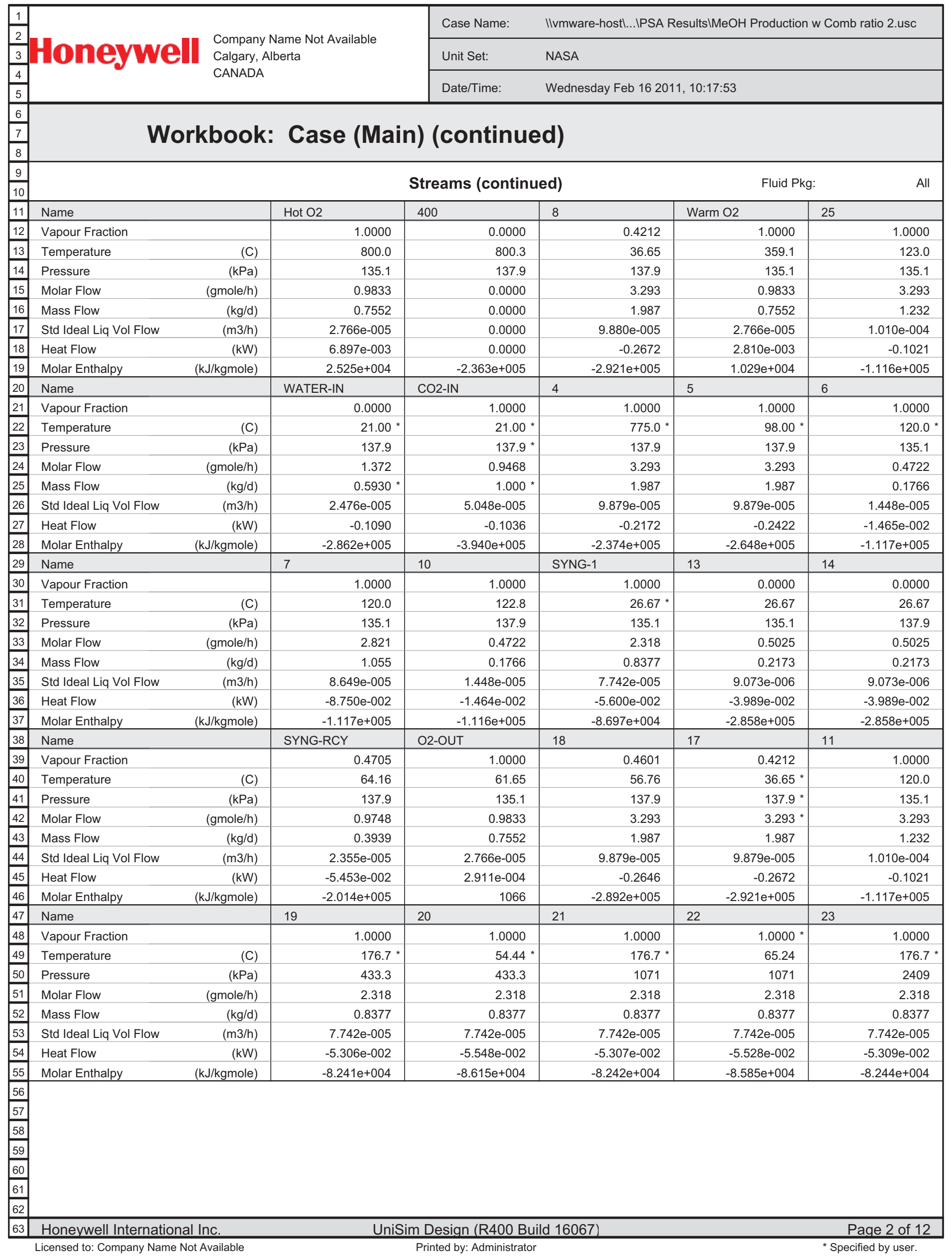




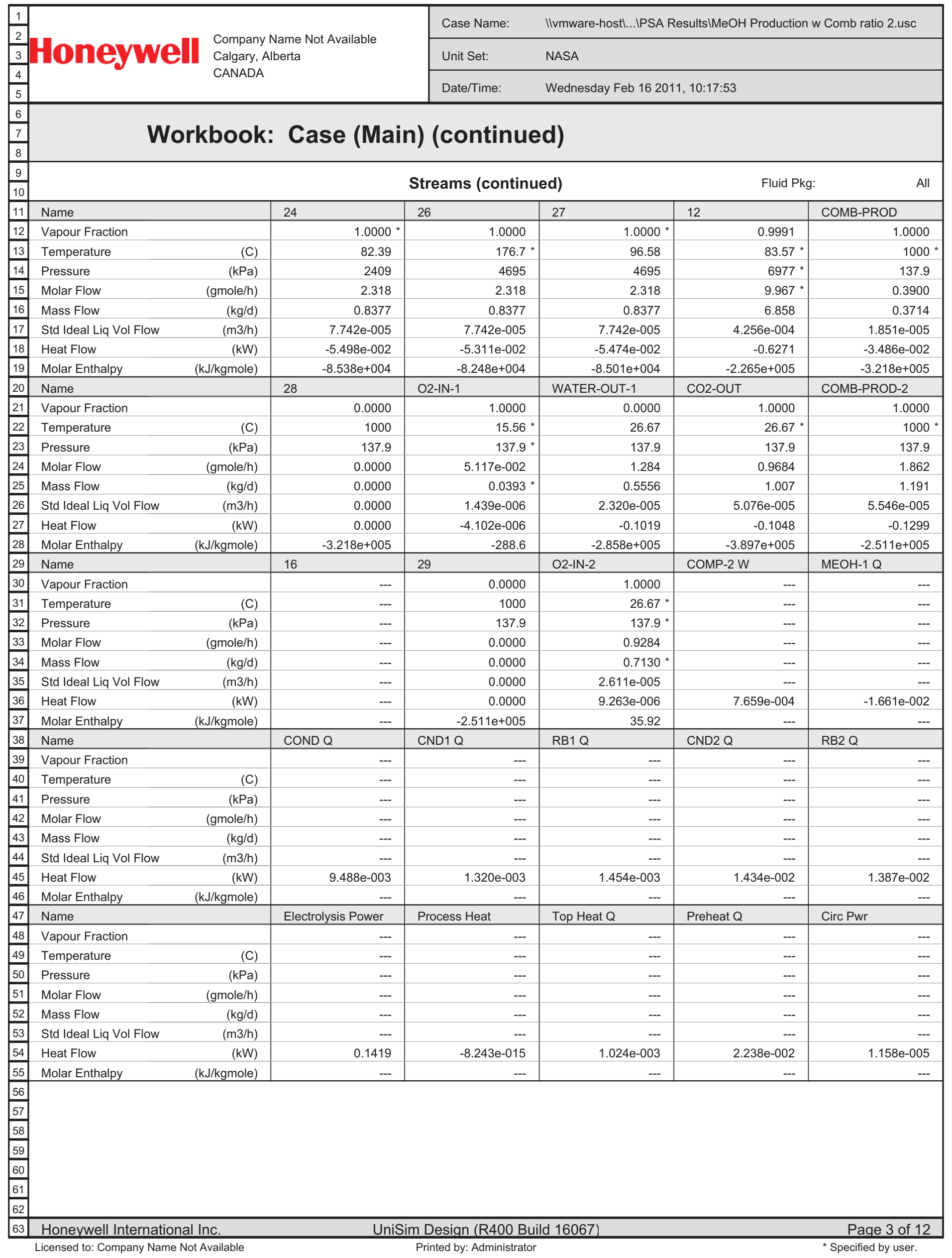




\begin{tabular}{|c|c|c|c|c|c|c|}
\hline \multirow{3}{*}{$\frac{4}{5}$} & \multirow{3}{*}{\multicolumn{2}{|c|}{$\begin{array}{l}\text { Company Name Not Available } \\
\text { Calgary, Alberta } \\
\text { CANADA }\end{array}$}} & \multirow{2}{*}{$\begin{array}{l}\text { Case Name: } \\
\text { Unit Set: }\end{array}$} & \multicolumn{3}{|c|}{ |lvmware-hostl...IPSA ResultsIMeOH Production w Comb ratio 2.usc } \\
\hline & & & & \multicolumn{3}{|l|}{ NASA } \\
\hline & & & Date/Time: & \multicolumn{3}{|c|}{ Wednesday Feb $162011,10: 17: 53$} \\
\hline$\frac{6}{\frac{7}{8}}$ & \multicolumn{6}{|c|}{ Workbook: Case (Main) (continued) } \\
\hline$\frac{9}{10}$ & \multicolumn{4}{|c|}{ Streams (continued) } & \multicolumn{2}{|c|}{ Fluid Pkg: } \\
\hline 11 & Name & Amb Q & Water Pump Pwr & ST1 PWR & IC1 Q & $\mathrm{IC} 2 \mathrm{Q}$ \\
\hline 12 & Vapour Fraction & --- & 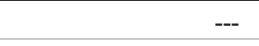 & --- & --- & --- \\
\hline 13 & Temperature & --- & --- & --- & --- & --- \\
\hline 14 & Pressure & --- & --- & --- & --- & -- \\
\hline 15 & Molar Flow & --- & --- & --- & --- & -- \\
\hline 16 & Mass Flow & -- & --- & --- & --- & -- \\
\hline 17 & Std Ideal Liq Vol Flow & --- & --- & --- & --- & --- \\
\hline 18 & Heat Flow & $-8.400 e-003$ & $9.193 \mathrm{e}-009$ & $2.940 \mathrm{e}-003$ & $2.412 \mathrm{e}-003$ & $2.212 \mathrm{e}-003$ \\
\hline 19 & Molar Enthalpy & --- & --- & --- & --- & -- \\
\hline 20 & Name & ST2 PWR & ST3 PWR & IC3 Q & STG4 PWR & IC4 Q \\
\hline 21 & Vapour Fraction & --- & --- & --- & --- & -- \\
\hline 22 & Temperature & --- & --- & --- & --- & --- \\
\hline 23 & Pressure & --- & --- & --- & --- & -- \\
\hline 24 & Molar Flow & --- & --- & --- & --- & -- \\
\hline 25 & Mass Flow & --- & --- & --- & --- & -- \\
\hline 26 & Std Ideal Liq Vol Flow & --- & --- & -- & --- & -- \\
\hline 27 & Heat Flow & $2.405 \mathrm{e}-003$ & $2.198 \mathrm{e}-003$ & $1.892 \mathrm{e}-003$ & $1.869 \mathrm{e}-003$ & $1.632 \mathrm{e}-003$ \\
\hline 28 & Molar Enthalpy & --- & --- & --- & --- & -- \\
\hline 29 & Name & STG5 PWR & COMB-Q-1 & AMB-Q-1 & COMB-Q-2 & \\
\hline 30 & Vapour Fraction & -- & --- & --- & --- & \\
\hline 31 & Temperature & --- & --- & --- & --- & \\
\hline 32 & Pressure & --- & --- & --- & --- & \\
\hline 33 & Molar Flow & --- & --- & --- & --- & \\
\hline 34 & Mass Flow & --- & --- & --- & --- & \\
\hline 35 & Std Ideal Liq Vol Flow & --- & --- & -- & --- & \\
\hline 36 & Heat Flow & $1.335 \mathrm{e}-003$ & $-1.945 e-003$ & $-4.204 e-002$ & $-8.844 \mathrm{e}-002$ & \\
\hline 37 & Molar Enthalpy & --- & --- & --- & --- & \\
\hline 38 & \multicolumn{4}{|c|}{ Composition } & \multicolumn{2}{|c|}{ Fluid Pkg: } \\
\hline 40 & Name & SYNG-2 & M-RECY2 & 1 & SYNG-3 & SYNG-5 \\
\hline 41 & Master Comp Mole Frac (H2O) & 0.0260 & 0.0006 & 0.0065 & 0.0065 & 0.0065 \\
\hline 42 & Master Comp Mole Frac (Oxygen) & 0.0000 & 0.0000 & 0.0000 & 0.0000 & 0.0000 \\
\hline 43 & Master Comp Mole Frac (Hydrogen) & 0.5656 & 0.2122 & 0.2944 & 0.2944 & 0.2944 \\
\hline 44 & Master Comp Mole Frac (CO) & 0.2828 & 0.1222 & 0.1595 & 0.1595 & 0.1595 \\
\hline 45 & Master Comp Mole Frac (CO2) & 0.1256 & 0.6372 & 0.5182 & 0.5182 & 0.5182 \\
\hline 46 & Master Comp Mole Frac (Methanol) & 0.0000 & 0.0277 & 0.0212 & 0.0212 & 0.0212 \\
\hline 47 & Master Comp Mole Frac (diM-Ether) & 0.0000 & 0.0002 & 0.0001 & 0.0001 & 0.0001 \\
\hline 48 & Master Comp Mole Frac (1-Propanol) & 0.0000 & 0.0000 & 0.0000 & 0.0000 & 0.0000 \\
\hline 49 & Name & MEOH-2 & $\mathrm{MEOH}-4$ & Vap Out & 2 & 3 \\
\hline 50 & Master Comp Mole Frac (H2O) & 0.0079 & 0.0079 & 0.0078 & 0.0075 & 0.0076 \\
\hline 51 & Master Comp Mole Frac (Oxygen) & 0.0000 & 0.0000 & 0.0000 & 0.0000 & 0.0000 \\
\hline 52 & Master Comp Mole Frac (Hydrogen) & 0.1923 & 0.1923 & 0.1923 & 0.1922 & 0.1922 \\
\hline 53 & Master Comp Mole Frac (CO) & 0.1108 & 0.1108 & 0.1108 & 0.1108 & 0.1108 \\
\hline 54 & Master Comp Mole Frac (CO2) & 0.5925 & 0.5925 & 0.5925 & 0.5929 & 0.5929 \\
\hline 55 & Master Comp Mole Frac (Methanol) & 0.0963 & 0.0963 & 0.0964 & 0.0964 & 0.0964 \\
\hline 56 & Master Comp Mole Frac (diM-Ether) & 0.0002 & 0.0002 & 0.0002 & 0.0002 & 0.0002 \\
\hline 57 & Master Comp Mole Frac (1-Propanol) & 0.0000 & 0.0000 & 0.0000 & 0.0000 & 0.0000 \\
\hline \begin{tabular}{|l|}
58 \\
59 \\
60 \\
61 \\
62 \\
\end{tabular} & & & & & & \\
\hline 63 & Honeywell International Inc. & Unis & n Design (R400 Bu & (d 16067) & & Page 4 of 12 \\
\hline
\end{tabular}




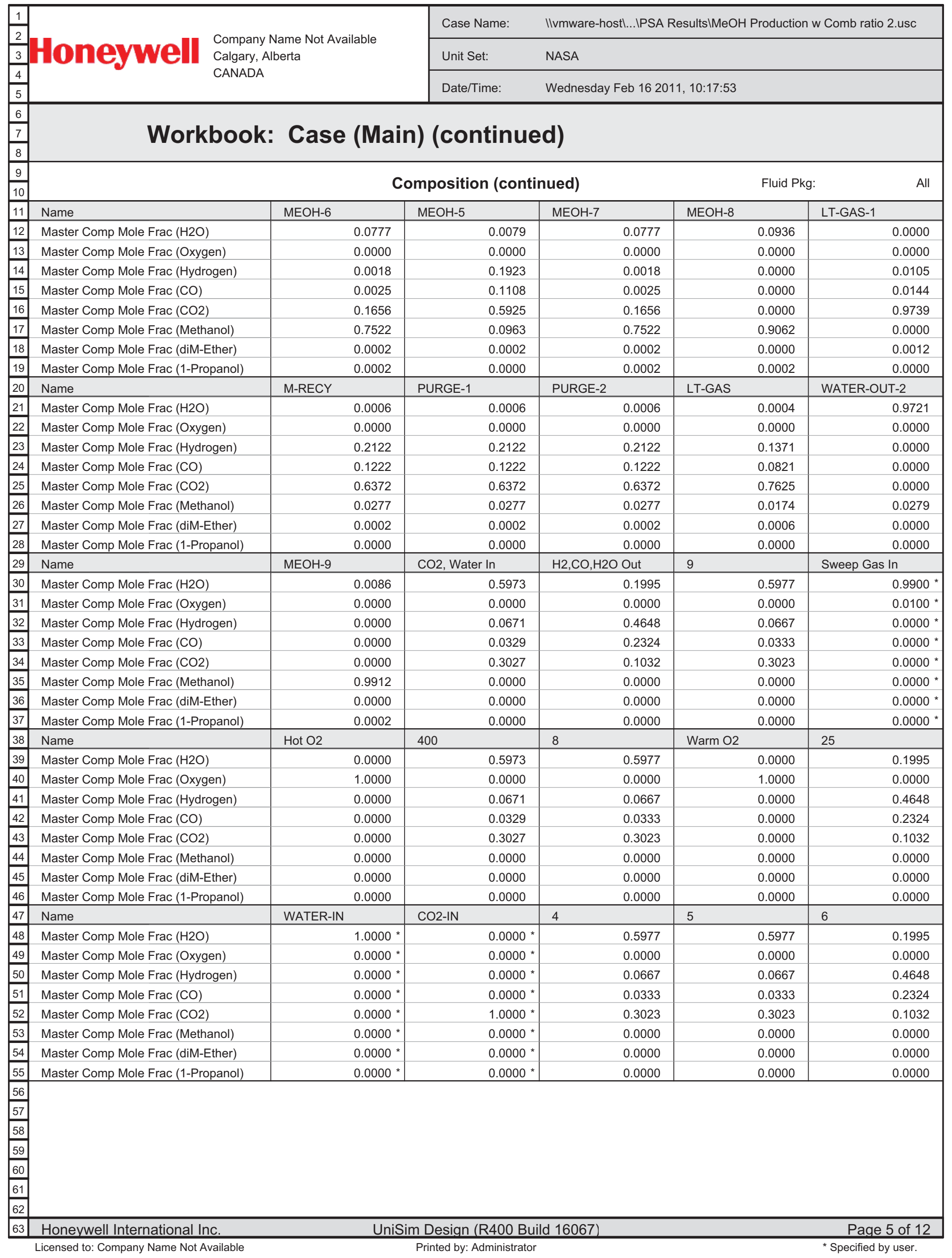




\begin{tabular}{|c|c|c|c|c|c|c|}
\hline 1 & & & Case Name: & IIvmware-hostl...IPSA & esults $\mid \mathrm{MeOH}$ Production & w Comb ratio 2.usc \\
\hline 3 & DOCNWE Calgar & perta & Unit Set: & NASA & & \\
\hline$\frac{7}{5}$ & URIVI & & Date/Time: & Wednesday Feb 1620 & $1,10: 17: 53$ & \\
\hline$\frac{6}{\frac{7}{8}}$ & Workboo & Case (Ma & ) (continue & d) & & \\
\hline$\frac{9}{10}$ & & & mposition (contir & hued) & Fluid Pkg & All \\
\hline 11 & Name & 7 & 10 & SYNG-1 & 13 & 14 \\
\hline 12 & Master Comp Mole Frac $(\mathrm{H} 2 \mathrm{O})$ & 0.1995 & 0.1995 & 0.0260 & 0.9999 & 0.9999 \\
\hline 13 & Master Comp Mole Frac (Oxygen) & 0.0000 & 0.0000 & 0.0000 & 0.0000 & 0.0000 \\
\hline 14 & Master Comp Mole Frac (Hydrogen) & 0.4648 & 0.4648 & 0.5656 & 0.0000 & 0.0000 \\
\hline 15 & Master Comp Mole Frac (CO) & 0.2324 & 0.2324 & 0.2828 & 0.0000 & 0.0000 \\
\hline 16 & Master Comp Mole Frac (CO2) & 0.1032 & 0.1032 & 0.1256 & 0.0001 & 0.0001 \\
\hline 17 & Master Comp Mole Frac (Methanol) & 0.0000 & 0.0000 & 0.0000 & 0.0000 & 0.0000 \\
\hline 18 & Master Comp Mole Frac (diM-Ether) & 0.0000 & 0.0000 & 0.0000 & 0.0000 & 0.0000 \\
\hline 19 & Master Comp Mole Frac (1-Propanol) & 0.0000 & 0.0000 & 0.0000 & 0.0000 & 0.0000 \\
\hline 20 & Name & SYNG-RCY & O2-OUT & 18 & 17 & 11 \\
\hline 21 & Master Comp Mole Frac $(\mathrm{H} 2 \mathrm{O})$ & 0.6122 & 0.0000 & 0.5977 & $0.5977^{*}$ & 0.1995 \\
\hline 22 & Master Comp Mole Frac (Oxygen) & 0.0000 & 1.0000 & 0.0000 & $0.0000 *$ & 0.0000 \\
\hline 23 & Master Comp Mole Frac (Hydrogen) & 0.2252 & 0.0000 & 0.0667 & $0.0667^{*}$ & 0.4648 \\
\hline 24 & Master Comp Mole Frac (CO) & 0.1126 & 0.0000 & 0.0333 & 0.0333 * & 0.2324 \\
\hline 25 & Master Comp Mole Frac (CO2) & 0.0500 & 0.0000 & 0.3023 & 0.3023 * & 0.1032 \\
\hline 26 & Master Comp Mole Frac (Methanol) & 0.0000 & 0.0000 & 0.0000 & $0.0000 *$ & 0.0000 \\
\hline 27 & Master Comp Mole Frac (diM-Ether) & 0.0000 & 0.0000 & 0.0000 & $0.0000 *$ & 0.0000 \\
\hline 28 & Master Comp Mole Frac (1-Propanol) & 0.0000 & 0.0000 & 0.0000 & $0.0000 *$ & 0.0000 \\
\hline 29 & Name & 19 & 20 & 21 & 22 & 23 \\
\hline 30 & Master Comp Mole Frac (H2O) & 0.0260 & 0.0260 & 0.0260 & 0.0260 & 0.0260 \\
\hline 31 & Master Comp Mole Frac (Oxygen) & 0.0000 & 0.0000 & 0.0000 & 0.0000 & 0.0000 \\
\hline 32 & Master Comp Mole Frac (Hydrogen) & 0.5656 & 0.5656 & 0.5656 & 0.5656 & 0.5656 \\
\hline 33 & Master Comp Mole Frac (CO) & 0.2828 & 0.2828 & 0.2828 & 0.2828 & 0.2828 \\
\hline 34 & Master Comp Mole Frac (CO2) & 0.1256 & 0.1256 & 0.1256 & 0.1256 & 0.1256 \\
\hline 35 & Master Comp Mole Frac (Methanol) & 0.0000 & 0.0000 & 0.0000 & 0.0000 & 0.0000 \\
\hline 36 & Master Comp Mole Frac (diM-Ether) & 0.0000 & 0.0000 & 0.0000 & 0.0000 & 0.0000 \\
\hline 37 & Master Comp Mole Frac (1-Propanol) & 0.0000 & 0.0000 & 0.0000 & 0.0000 & 0.0000 \\
\hline 38 & Name & 24 & 26 & 27 & 12 & COMB-PROD \\
\hline 39 & Master Comp Mole Frac $(\mathrm{H} 2 \mathrm{O})$ & 0.0260 & 0.0260 & 0.0260 & $0.0065^{*}$ & 0.1665 \\
\hline 40 & Master Comp Mole Frac (Oxygen) & 0.0000 & 0.0000 & 0.0000 & $0.0000 *$ & 0.0001 \\
\hline 41 & Master Comp Mole Frac (Hydrogen) & 0.5656 & 0.5656 & 0.5656 & $0.2944 *$ & 0.0000 \\
\hline 42 & Master Comp Mole Frac (CO) & 0.2828 & 0.2828 & 0.2828 & $0.1595 *$ & 0.0000 \\
\hline 43 & Master Comp Mole Frac (CO2) & 0.1256 & 0.1256 & 0.1256 & $0.5182 *$ & 0.8329 \\
\hline 44 & Master Comp Mole Frac (Methanol) & 0.0000 & 0.0000 & 0.0000 & $0.0212 *$ & 0.0000 \\
\hline 45 & Master Comp Mole Frac (diM-Ether) & 0.0000 & 0.0000 & 0.0000 & $0.0001 *$ & 0.0005 \\
\hline 46 & Master Comp Mole Frac (1-Propanol) & 0.0000 & 0.0000 & 0.0000 & $0.0000 *$ & 0.0000 \\
\hline 47 & Name & 28 & $\mathrm{O} 2-\mathrm{IN}-1$ & WATER-OUT-1 & CO2-OUT & COMB-PROD-2 \\
\hline 48 & Master Comp Mole Frac (H2O) & 0.1665 & $0.0000 *$ & 0.9994 & 0.0259 & 0.6676 \\
\hline 49 & Master Comp Mole Frac (Oxygen) & 0.0001 & $1.0000 *$ & 0.0000 & 0.0001 & 0.0000 \\
\hline 50 & Master Comp Mole Frac (Hydrogen) & 0.0000 & $0.0000 *$ & 0.0000 & 0.0000 & 0.0000 \\
\hline 51 & Master Comp Mole Frac (CO) & 0.0000 & $0.0000 *$ & 0.0000 & 0.0000 & 0.0000 \\
\hline 52 & Master Comp Mole Frac (CO2) & 0.8329 & $0.0000 *$ & 0.0006 & 0.9736 & 0.3323 \\
\hline 53 & Master Comp Mole Frac (Methanol) & 0.0000 & $0.0000 *$ & 0.0000 & 0.0000 & 0.0000 \\
\hline 54 & Master Comp Mole Frac (diM-Ether) & 0.0005 & $0.0000 *$ & 0.0000 & 0.0002 & 0.0000 \\
\hline 55 & Master Comp Mole Frac (1-Propanol) & 0.0000 & $0.0000 *$ & 0.0000 & 0.0001 & 0.0001 \\
\hline \begin{tabular}{|l|}
56 \\
57 \\
58 \\
59 \\
60 \\
61 \\
62 \\
\end{tabular} & & & & & & \\
\hline 63 & Honeywell International Inc. & Uni & n Design (R400 Buil & Id 16067) & & Page 6 of 12 \\
\hline
\end{tabular}




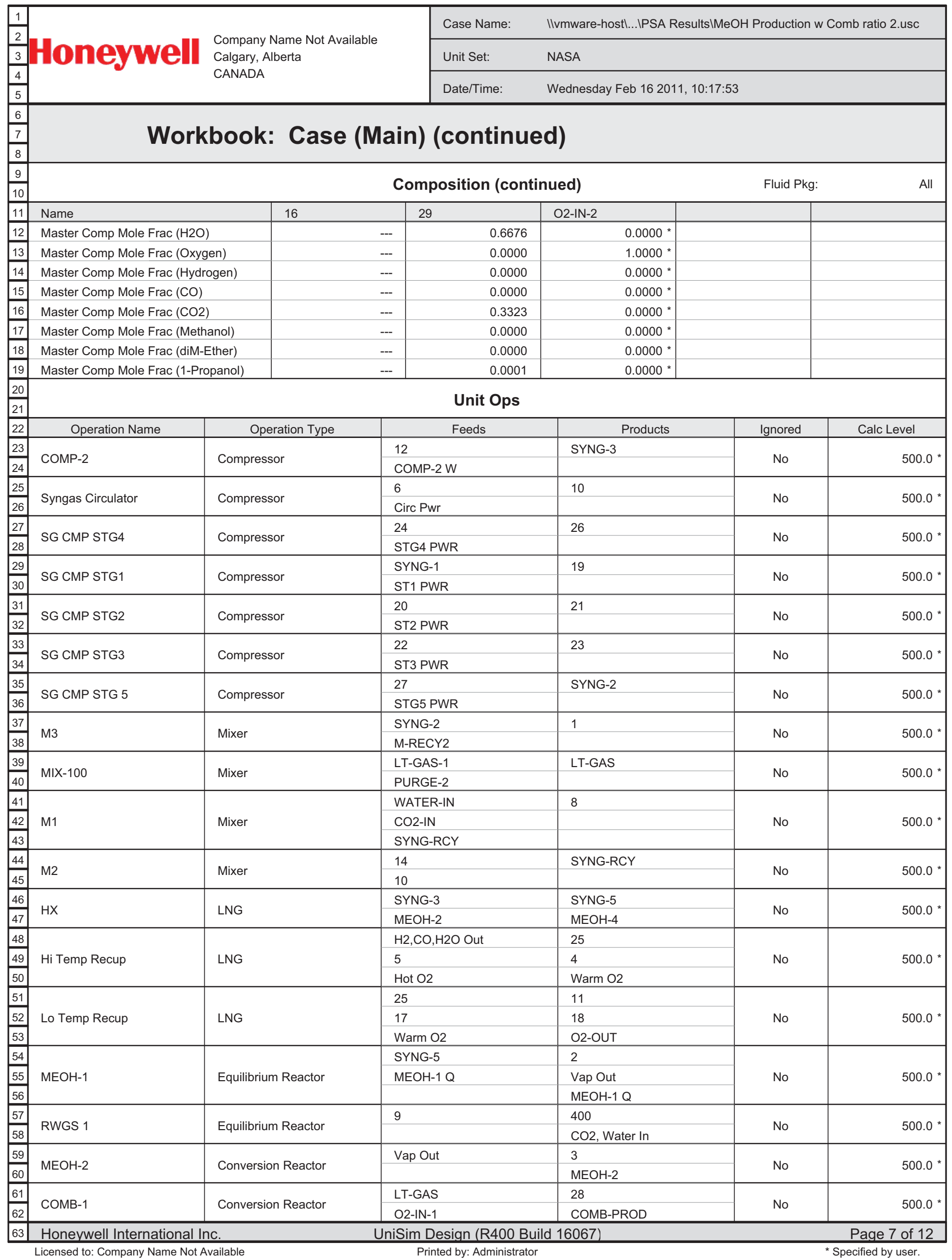




\begin{tabular}{|c|c|c|c|c|c|c|}
\hline 1 & & & Case Name: & |lvmware-hostl...IPSA F & Production & $\mathrm{mb}$ ratio 2 .usc \\
\hline 3 & Honey & Calgary, Alberta & Unit Set: & NASA & & \\
\hline$\frac{4}{5}$ & & 每 & Date/Time: & Wednesday Feb 1620 & & \\
\hline$\frac{6}{7}$ & Work & book: Case (N & ain) (contin & d) & & \\
\hline$\frac{9}{10}$ & & & Unit Ops (con & ed) & & \\
\hline 11 & Operation Name & Operation Type & Feeds & Products & Ignored & Calc Level \\
\hline 12 & COMB-1 & Conversion Reactor & COMB-Q-1 & COMB-Q-1 & No & 500.0 * \\
\hline 13 & & & MEOH-9 & 29 & & \\
\hline 14 & COMB-2 & Conversion Reactor & $\mathrm{O} 2-\mathrm{IN}-2$ & COMB-PROD-2 & No & $500.0 *$ \\
\hline 15 & & & COMB-Q-2 & COMB-Q-2 & & \\
\hline 16 & KORRM & & MEOH-5 & MEOH-6 & $\mathrm{No}$ & 5000 * $>2 \div<\div$ \\
\hline 17 & nU-DTIVI & separator & & M-RECY & INO & 500.0 \\
\hline 18 & & & 7 & 13 & & \\
\hline 19 & Water Knockout Tank & Separator & $A m b$ Q & SYNG-1 & No & 500.0 * \\
\hline 20 & & & & Amb Q & & \\
\hline 21 & & & COMB-PROD & WATER-OUT-1 & & \\
\hline 22 & KO-DRM 2 & Separator & COMB-PROD-2 & CO2-OUT & No & $500.0 *$ \\
\hline 23 & & & AMB-Q-1 & AMB-Q-1 & & \\
\hline 24 & CONDNSR & Cooler & $\mathrm{MEOH}-4$ & MEOH-5 & $\mathrm{No}$ & 5000 * $>2>0$ \\
\hline 25 & COINDTVOR & Cooler & & COND Q & INO & 500.0 \\
\hline 26 & INT CI R 1 & Cooler & 19 & 20 & $\mathrm{No}$ & 5000 * $>2>>0$ \\
\hline 27 & IVI CLR I & Cooler & & IC1 Q & INO & 500.0 \\
\hline 28 & INT CIR 2 & Cooler & 21 & 22 & $\mathrm{No}$ & 5000 * $>2>0$ \\
\hline 29 & IIVI CLR 2 & Couler & & $\mathrm{IC} 2 \mathrm{Q}$ & INO & 500.0 \\
\hline 30 & INT CIR 3 & Cooler & 23 & 24 & $\mathrm{No}$ & 5000 * $>2>0$ \\
\hline 31 & 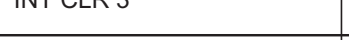 & Couler & & IC3 Q & INO & 500.0 \\
\hline 32 & INT CI R 4 & Cooler & 26 & 27 & $\mathrm{No}$ & 5000 * $>2>0$ \\
\hline 33 & 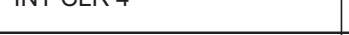 & Covici & & IC4 Q & To & 000.0 \\
\hline 34 & VALVE-3 & Valve & MEOH-6 & $\mathrm{MEOH}-7$ & No & 500.0 * \\
\hline 35 & VALVE-2 & Valve & PURGE-1 & PURGE-2 & No & 500.0 * \\
\hline 36 & & & MEOH-7 & MEOH-8 & & \\
\hline 37 & $T-100$ & Distillation & RB1 Q & LT-GAS-1 & No & 2500 * \\
\hline 38 & & & & CND1 Q & & \\
\hline 39 & & & MEOH-8 & WATER-OUT-2 & & \\
\hline 40 & $\mathrm{~T}-101$ & Distillation & RB2 Q & MEOH-9 & No & 2500 * \\
\hline 41 & & & & CND2 Q & & \\
\hline 42 & $\mathrm{RCY}-4$ & Recycle & 8 & 17 & No & 3500 * \\
\hline 43 & $\mathrm{RCY}-1$ & Recycle & 1 & 12 & No & 3500 * \\
\hline 44 & TFF-100 & Tee & M-RECY & M-RECY2 & $\mathrm{No}$ & 5000 * $>2>>0$ \\
\hline 45 & TEE-IOU & 1ee & & PURGE-1 & No & 500.0 \\
\hline 46 & $T 1$ & Tee & 11 & 6 & $\mathrm{No}$ & 5000 * $>2 \div<\div$ \\
\hline 47 & 11 & 1ee & & 7 & INO & 500.0 \\
\hline 48 & & & Sweep Gas In & Hot O2 & & \\
\hline 49 & Hiah Temnerature Co-Flectrol & Standard Sub-Flowsheet & $\mathrm{CO} 2$, Water In & $\mathrm{H} 2, \mathrm{CO}, \mathrm{H} 2 \mathrm{O}$ Out & No & $2500 *$ \\
\hline 50 & Hign Iemperature Co-Electrol & Standard Sub-rlowsneet & Process Heat & & No & 2500 \\
\hline 51 & & & Electrolysis Power & & & \\
\hline 52 & Tonning Heat & Heater & 4 & 9 & $\mathrm{No}$ & 5000 * $>2>>0$ \\
\hline 53 & I Opping neal & Mealer & Top Heat Q & & NO & 500.0 \\
\hline 54 & Preheater & Heater & 18 & 5 & $\mathrm{No}$ & 5000 * $>2>0$ \\
\hline 55 & Preneater & 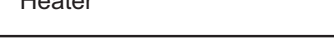 & Preheat Q & & NO & 500.0 \\
\hline 56 & SPRDSHT-1 & Spreadsheet & & & No & 500.0 * \\
\hline 57 & Water Pumn & Pumn & 13 & 14 & No & 5000 * $>2>0$ \\
\hline 58 & Water Pump & Pump & Water Pump Pwr & & No & 500.0 \\
\hline 59 & & & & & & \\
\hline 60 & & & & & & \\
\hline $\begin{array}{l}61 \\
62\end{array}$ & & & & & & \\
\hline 63 & Honeywell International In & c. & niSim Design (R400 & d 16067) & & Page 8 of 12 \\
\hline
\end{tabular}




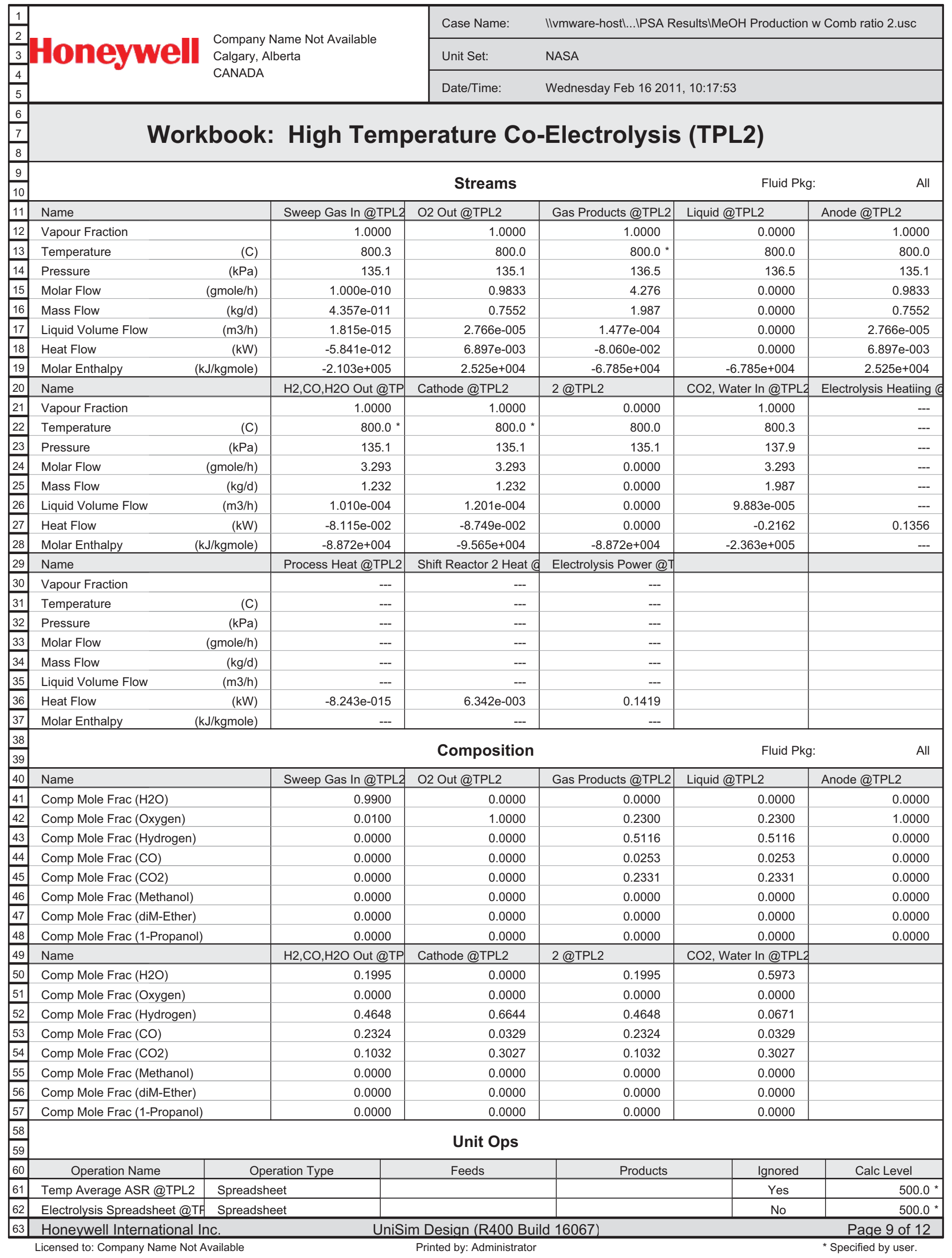




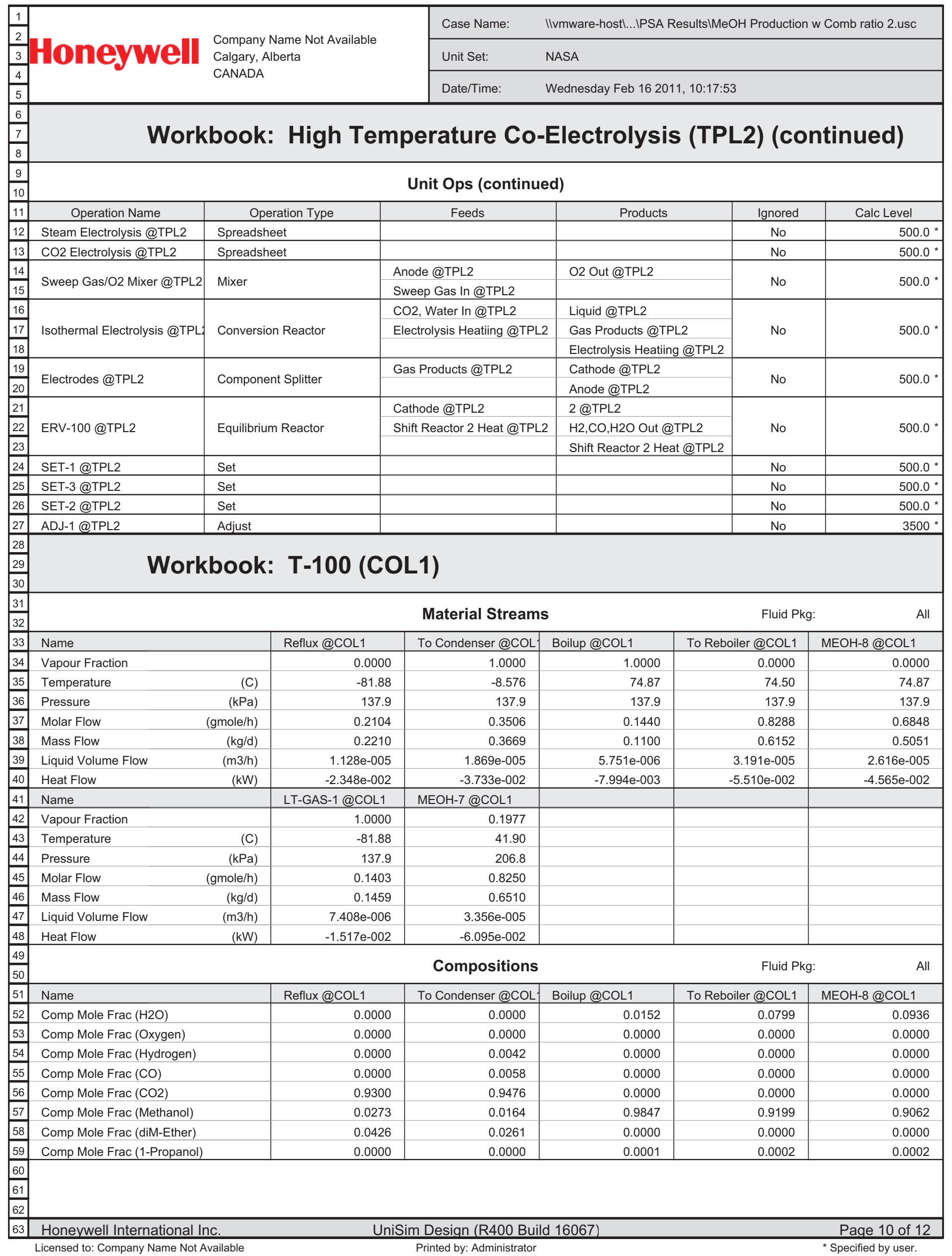




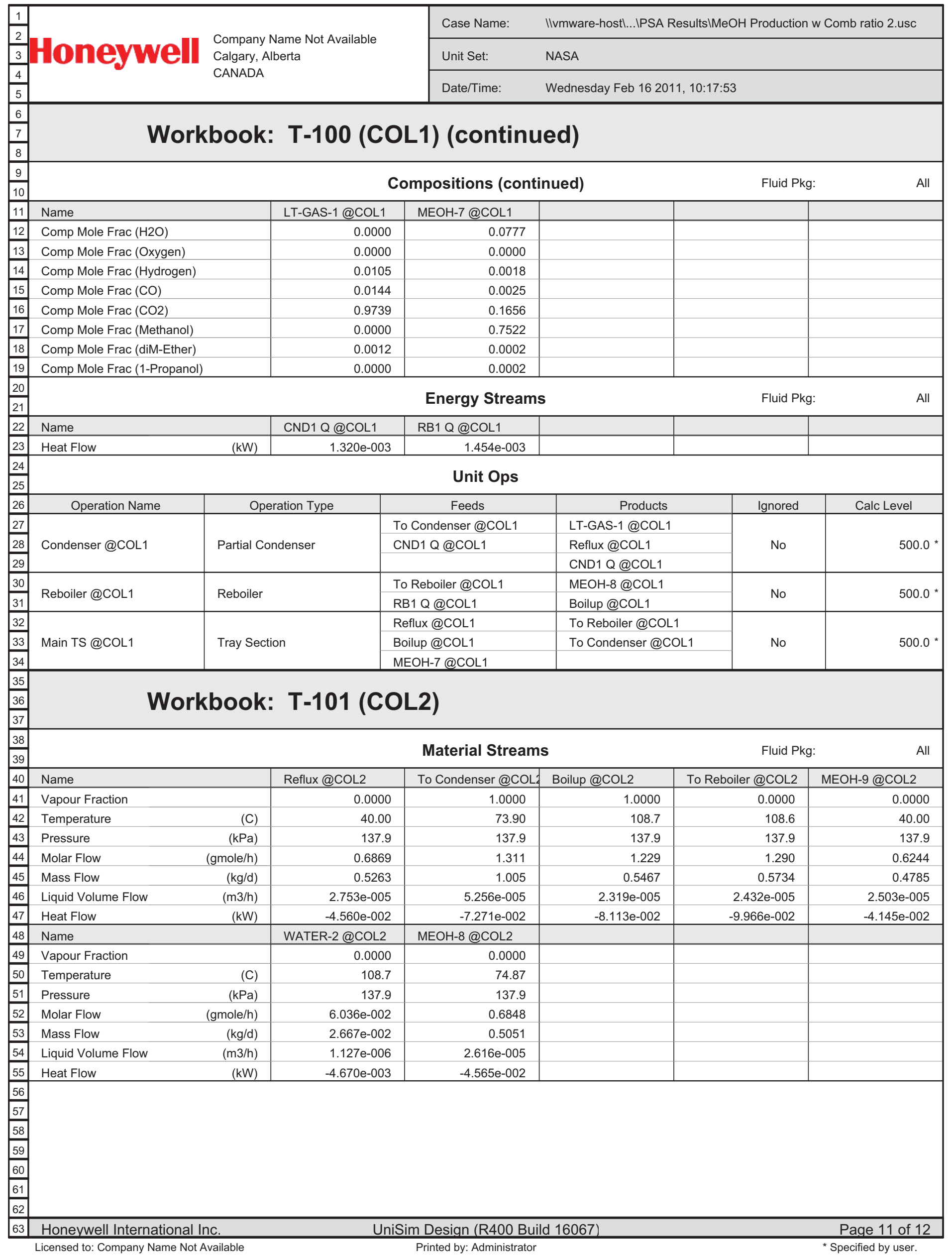




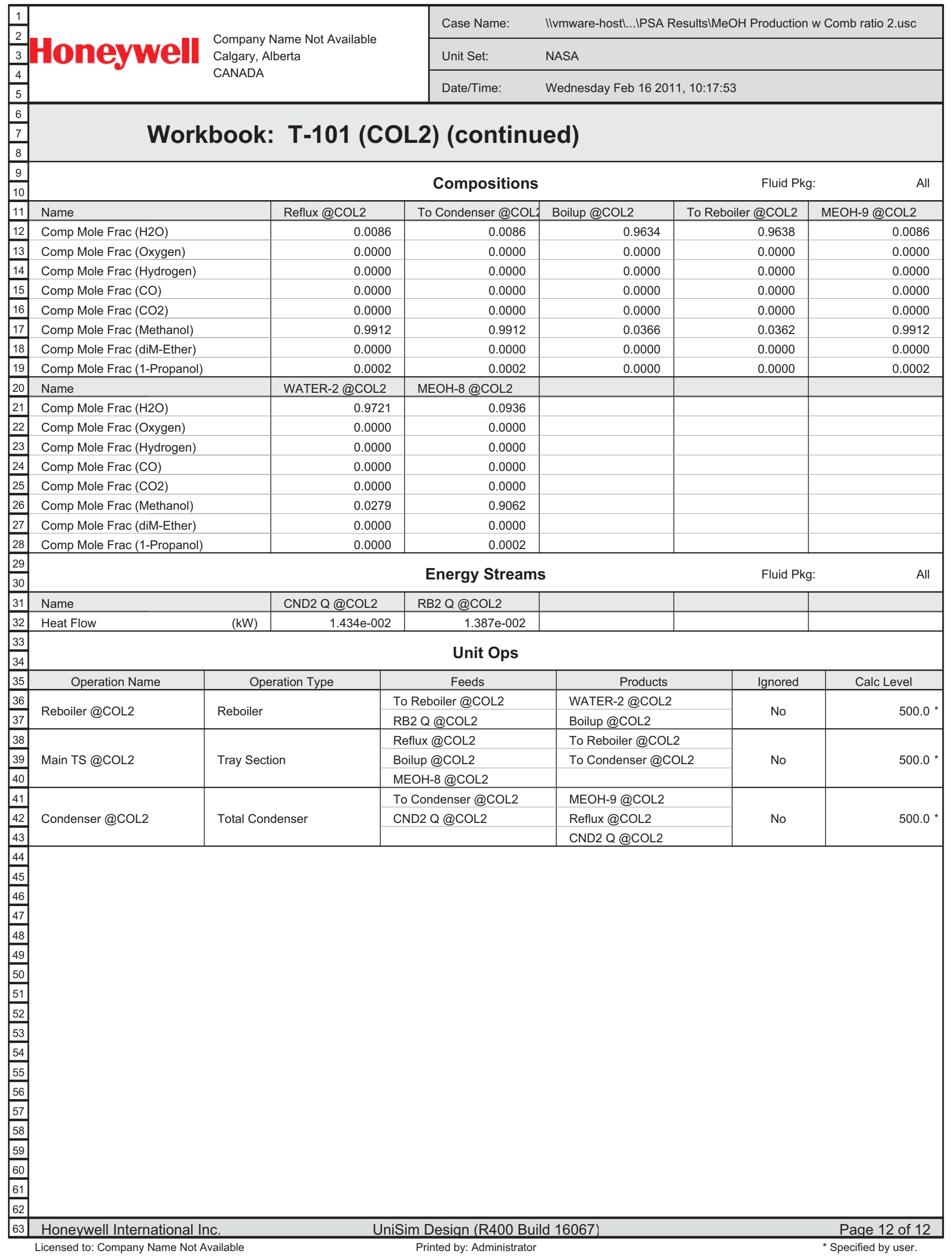




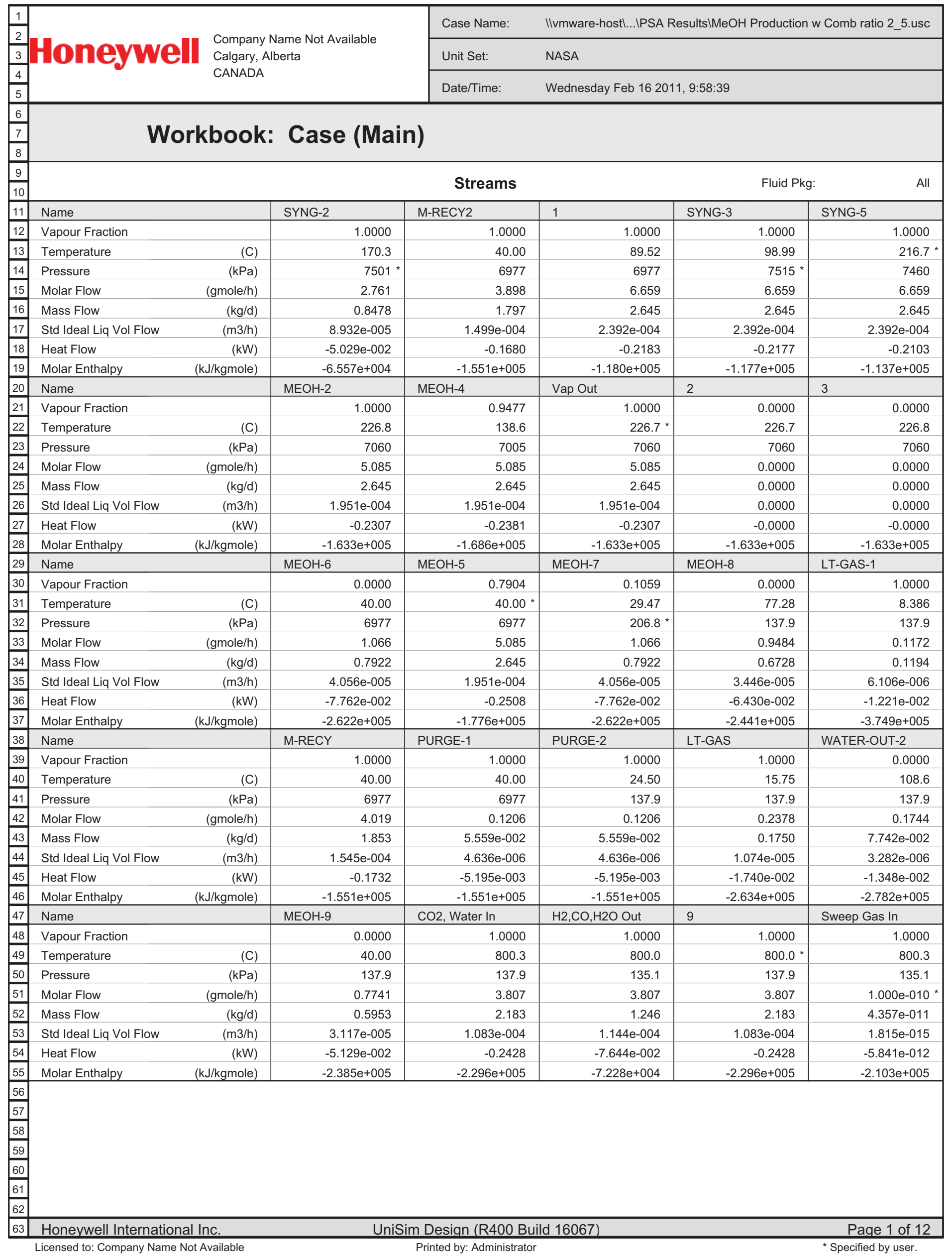




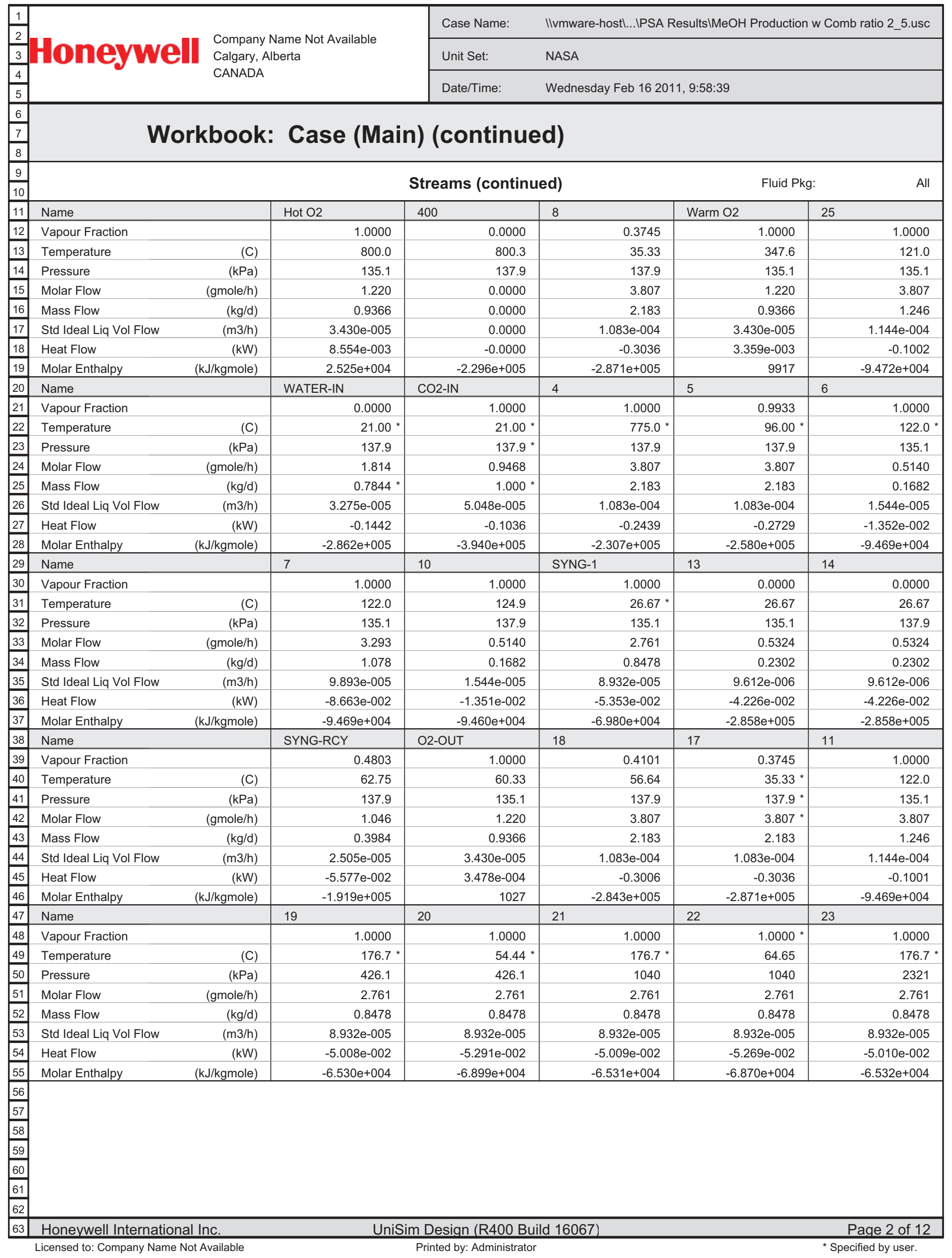




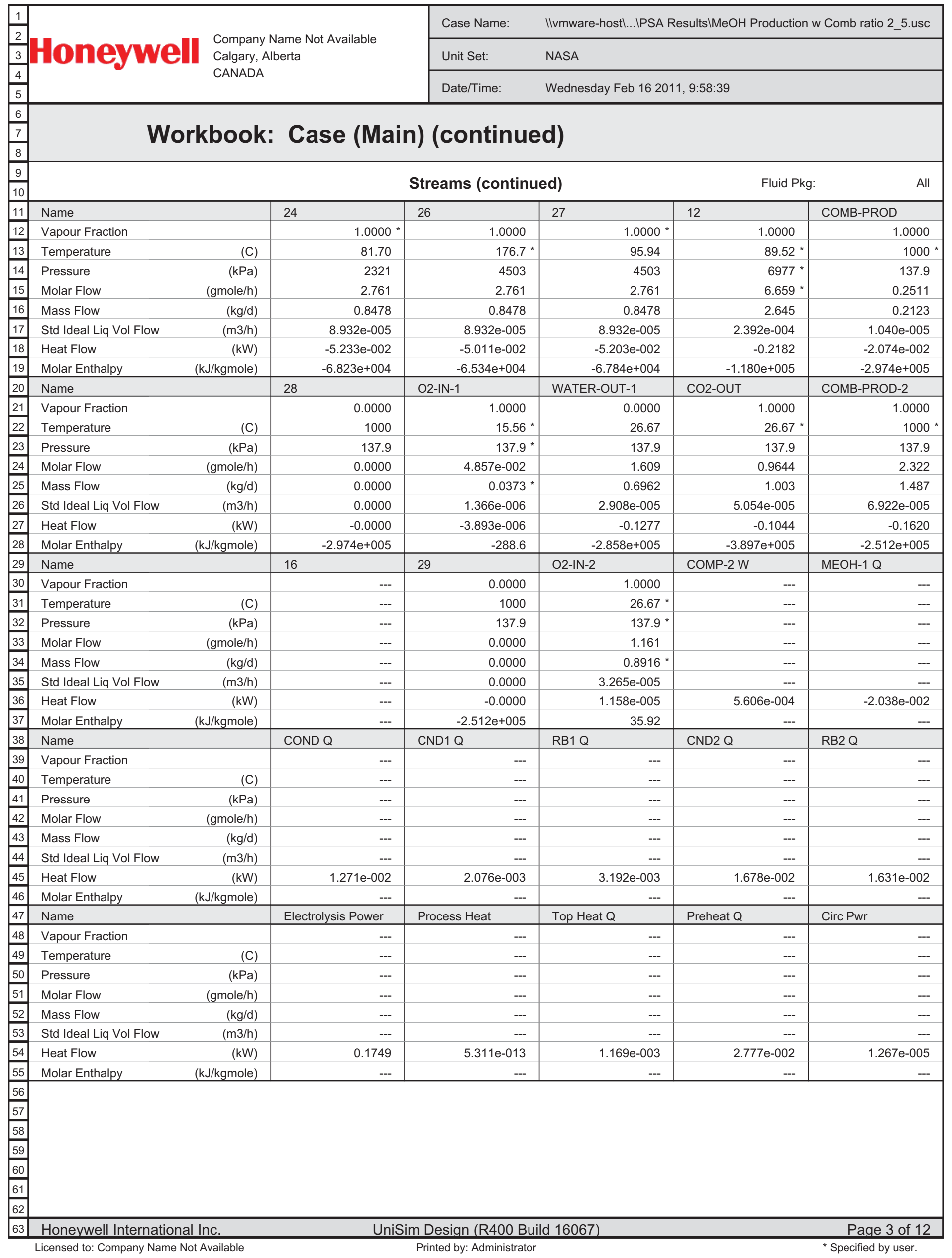




\begin{tabular}{|c|c|c|c|c|c|c|}
\hline 1 & \multirow{3}{*}{\multicolumn{2}{|c|}{$\begin{array}{l}\text { Company Name Not Available } \\
\text { Calgary, Alberta } \\
\text { CANADA }\end{array}$}} & Case Name: & \multicolumn{3}{|c|}{ IIvmware-hostl...IPSA ResultsIMeOH Production w Comb ratio 2_5.usc } \\
\hline 3 & & & Unit Set: & \multicolumn{3}{|l|}{ NASA } \\
\hline$\frac{4}{5}$ & & & Date/Time: & \multicolumn{3}{|c|}{ Wednesday Feb 16 2011, 9:58:39 } \\
\hline$\frac{6}{\frac{7}{8}}$ & \multicolumn{6}{|c|}{ Workbook: Case (Main) (continued) } \\
\hline$\frac{9}{10}$ & \multicolumn{4}{|c|}{ Streams (continued) } & \multicolumn{2}{|c|}{ Fluid Pkg: } \\
\hline 11 & Name & Amb Q & Water Pump Pwr & ST1 PWR & IC1 Q & $\mathrm{IC} 2 \mathrm{Q}$ \\
\hline 12 & Vapour Fraction & --- & 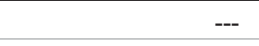 & --- & --- & --- \\
\hline 13 & Temperature & -- & --- & --- & --- & --- \\
\hline 14 & Pressure & --- & --- & --- & --- & -- \\
\hline 15 & Molar Flow & -- & --- & --- & --- & -- \\
\hline 16 & Mass Flow & -- & --- & --- & --- & -- \\
\hline 17 & Std Ideal Liq Vol Flow & --- & --- & --- & --- & --- \\
\hline 18 & Heat Flow & $-9.166 e-003$ & $9.739 \mathrm{e}-009$ & $3.452 \mathrm{e}-003$ & $2.828 \mathrm{e}-003$ & $2.605 e-003$ \\
\hline 19 & Molar Enthalpy & --- & --- & --- & -- & -- \\
\hline 20 & Name & ST2 PWR & ST3 PWR & IC3 Q & STG4 PWR & IC4 Q \\
\hline 21 & Vapour Fraction & --- & --- & --- & --- & -- \\
\hline 22 & Temperature & --- & --- & --- & --- & --- \\
\hline 23 & Pressure & --- & --- & --- & -- & -- \\
\hline 24 & Molar Flow & --- & --- & --- & -- & -- \\
\hline 25 & Mass Flow & --- & --- & --- & --- & -- \\
\hline 26 & Std Ideal Liq Vol Flow & --- & --- & -- & -- & -- \\
\hline 27 & Heat Flow & $2.823 e-003$ & $2.594 \mathrm{e}-003$ & $2.229 \mathrm{e}-003$ & $2.212 \mathrm{e}-003$ & $1.919 e-003$ \\
\hline 28 & Molar Enthalpy & --- & --- & --- & --- & -- \\
\hline 29 & Name & STG5 PWR & COMB-Q-1 & AMB-Q-1 & COMB-Q-2 & \\
\hline 30 & Vapour Fraction & --- & --- & --- & --- & \\
\hline 31 & Temperature & --- & --- & --- & --- & \\
\hline 32 & Pressure & --- & --- & --- & -- & \\
\hline 33 & Molar Flow & --- & --- & --- & -- & \\
\hline 34 & Mass Flow & --- & --- & --- & --- & \\
\hline 35 & Std Ideal Liq Vol Flow & --- & --- & -- & -- & \\
\hline 36 & Heat Flow & $1.746 \mathrm{e}-003$ & $-3.335 e-003$ & $-4.936 e-002$ & -0.1108 & \\
\hline 37 & Molar Enthalpy & -- & --- & --- & --- & \\
\hline \begin{tabular}{|l}
38 \\
39 \\
\end{tabular} & \multicolumn{4}{|c|}{ Composition } & \multicolumn{2}{|c|}{ Fluid Pkg: } \\
\hline 40 & Name & SYNG-2 & M-RECY2 & 1 & SYNG-3 & SYNG-5 \\
\hline 41 & Master Comp Mole Frac (H2O) & 0.0260 & 0.0003 & 0.0109 & 0.0109 & 0.0109 \\
\hline 42 & Master Comp Mole Frac (Oxygen) & 0.0000 & 0.0000 & 0.0000 & 0.0000 & 0.0000 \\
\hline 43 & Master Comp Mole Frac (Hydrogen) & 0.6311 & 0.5725 & 0.5968 & 0.5968 & 0.5968 \\
\hline 44 & Master Comp Mole Frac (CO) & 0.2524 & 0.0419 & 0.1292 & 0.1292 & 0.1292 \\
\hline 45 & Master Comp Mole Frac (CO2) & 0.0905 & 0.3782 & 0.2589 & 0.2589 & 0.2589 \\
\hline 46 & Master Comp Mole Frac (Methanol) & 0.0000 & 0.0070 & 0.0041 & 0.0041 & 0.0041 \\
\hline 47 & Master Comp Mole Frac (diM-Ether) & 0.0000 & 0.0002 & 0.0001 & 0.0001 & 0.0001 \\
\hline 48 & Master Comp Mole Frac (1-Propanol) & 0.0000 & 0.0000 & 0.0000 & 0.0000 & 0.0000 \\
\hline 49 & Name & $\mathrm{MEOH}-2$ & $\mathrm{MEOH}-4$ & Vap Out & 2 & 3 \\
\hline 50 & Master Comp Mole Frac (H2O) & 0.0333 & 0.0333 & 0.0332 & 0.0332 & 0.0333 \\
\hline 51 & Master Comp Mole Frac (Oxygen) & 0.0000 & 0.0000 & 0.0000 & 0.0000 & 0.0000 \\
\hline 52 & Master Comp Mole Frac (Hydrogen) & 0.4530 & 0.4530 & 0.4530 & 0.4530 & 0.4530 \\
\hline 53 & Master Comp Mole Frac (CO) & 0.0332 & 0.0332 & 0.0332 & 0.0332 & 0.0332 \\
\hline 54 & Master Comp Mole Frac (CO2) & 0.3202 & 0.3202 & 0.3202 & 0.3202 & 0.3202 \\
\hline 55 & Master Comp Mole Frac (Methanol) & 0.1601 & 0.1601 & 0.1602 & 0.1602 & 0.1601 \\
\hline 56 & Master Comp Mole Frac (diM-Ether) & 0.0002 & 0.0002 & 0.0001 & 0.0001 & 0.0002 \\
\hline 57 & Master Comp Mole Frac (1-Propanol) & 0.0000 & 0.0000 & 0.0000 & 0.0000 & 0.0000 \\
\hline \begin{tabular}{|l|}
58 \\
59 \\
60 \\
61 \\
62 \\
\end{tabular} & & & & & & \\
\hline 63 & Honeywell International Inc. & Unis & $\mathrm{n}$ Design (R400 Bu & (d 16067) & & Page 4 of 12 \\
\hline
\end{tabular}




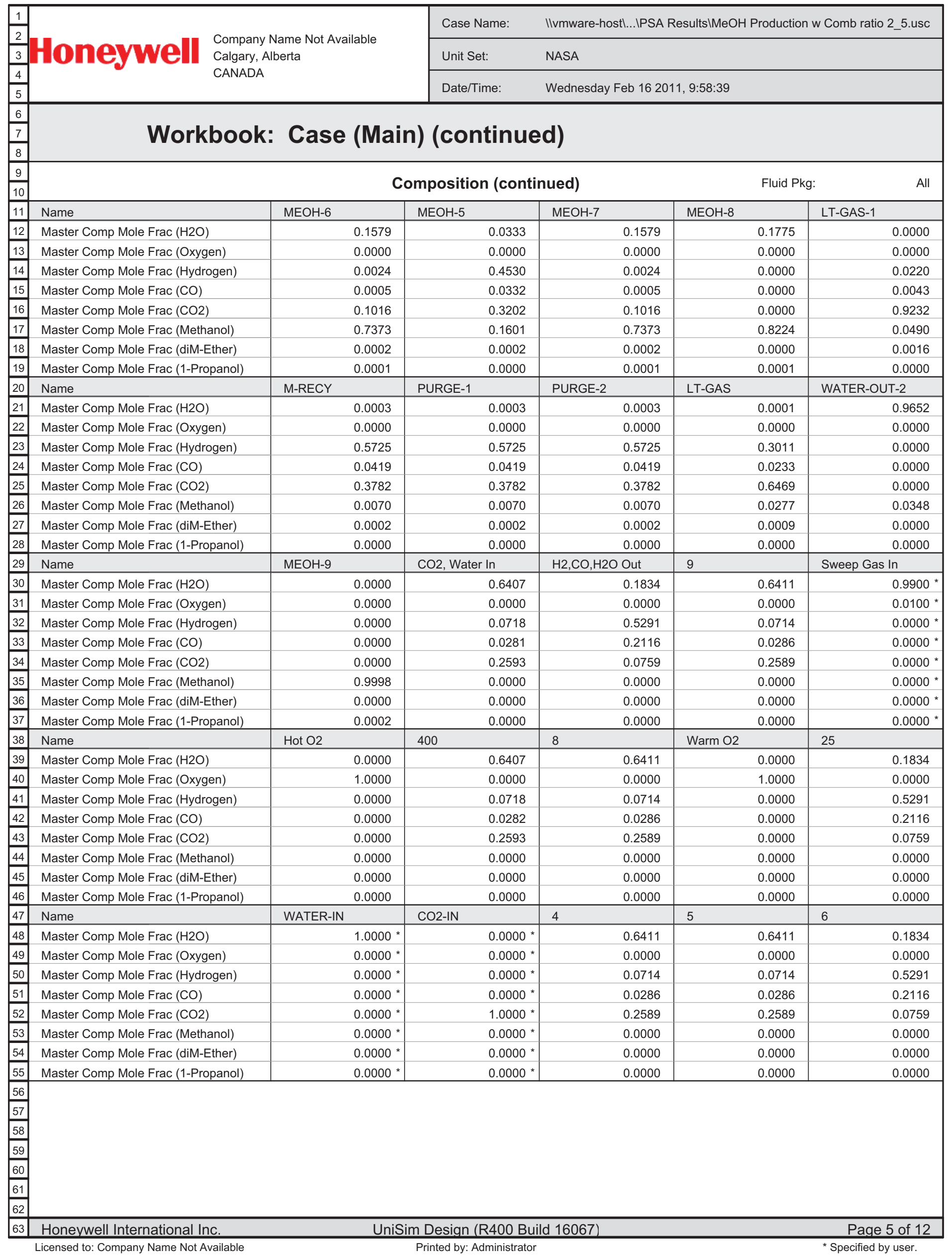




\begin{tabular}{|c|c|c|c|c|c|c|}
\hline 1 & & & Case Name: & IIvmware-hostl...IPSA & esults $\mid \mathrm{MeOH}$ Production & w Comb ratio 2_5.usc \\
\hline 3 & DOCNWE Calgar & perta & Unit Set: & NASA & & \\
\hline$\frac{7}{5}$ & URIVI & & Date/Time: & Wednesday Feb 1620 & 1, 9:58:39 & \\
\hline$\frac{6}{\frac{7}{8}}$ & Workboo & Case (Ma & ) (continue & d) & & \\
\hline$\frac{9}{10}$ & & & mposition (contir & hued) & Fluid Pkg & All \\
\hline 11 & Name & 7 & 10 & SYNG-1 & 13 & 14 \\
\hline 12 & Master Comp Mole Frac $(\mathrm{H} 2 \mathrm{O})$ & 0.1834 & 0.1834 & 0.0260 & 0.9999 & 0.9999 \\
\hline 13 & Master Comp Mole Frac (Oxygen) & 0.0000 & 0.0000 & 0.0000 & 0.0000 & 0.0000 \\
\hline 14 & Master Comp Mole Frac (Hydrogen) & 0.5291 & 0.5291 & 0.6311 & 0.0000 & 0.0000 \\
\hline 15 & Master Comp Mole Frac (CO) & 0.2116 & 0.2116 & 0.2524 & 0.0000 & 0.0000 \\
\hline 16 & Master Comp Mole Frac (CO2) & 0.0759 & 0.0759 & 0.0905 & 0.0001 & 0.0001 \\
\hline 17 & Master Comp Mole Frac (Methanol) & 0.0000 & 0.0000 & 0.0000 & 0.0000 & 0.0000 \\
\hline 18 & Master Comp Mole Frac (diM-Ether) & 0.0000 & 0.0000 & 0.0000 & 0.0000 & 0.0000 \\
\hline 19 & Master Comp Mole Frac (1-Propanol) & 0.0000 & 0.0000 & 0.0000 & 0.0000 & 0.0000 \\
\hline 20 & Name & SYNG-RCY & O2-OUT & 18 & 17 & 11 \\
\hline 21 & Master Comp Mole Frac $(\mathrm{H} 2 \mathrm{O})$ & 0.5989 & 0.0000 & 0.6411 & $0.6411^{*}$ & 0.1834 \\
\hline 22 & Master Comp Mole Frac (Oxygen) & 0.0000 & 1.0000 & 0.0000 & $0.0000 *$ & 0.0000 \\
\hline 23 & Master Comp Mole Frac (Hydrogen) & 0.2599 & 0.0000 & 0.0714 & 0.0714 * & 0.5291 \\
\hline 24 & Master Comp Mole Frac (CO) & 0.1039 & 0.0000 & 0.0286 & $0.0286 *$ & 0.2116 \\
\hline 25 & Master Comp Mole Frac (CO2) & 0.0373 & 0.0000 & 0.2589 & $0.2589 *$ & 0.0759 \\
\hline 26 & Master Comp Mole Frac (Methanol) & 0.0000 & 0.0000 & 0.0000 & $0.0000 *$ & 0.0000 \\
\hline 27 & Master Comp Mole Frac (diM-Ether) & 0.0000 & 0.0000 & 0.0000 & $0.0000 *$ & 0.0000 \\
\hline 28 & Master Comp Mole Frac (1-Propanol) & 0.0000 & 0.0000 & 0.0000 & $0.0000 *$ & 0.0000 \\
\hline 29 & Name & 19 & 20 & 21 & 22 & 23 \\
\hline 30 & Master Comp Mole Frac (H2O) & 0.0260 & 0.0260 & 0.0260 & 0.0260 & 0.0260 \\
\hline 31 & Master Comp Mole Frac (Oxygen) & 0.0000 & 0.0000 & 0.0000 & 0.0000 & 0.0000 \\
\hline 32 & Master Comp Mole Frac (Hydrogen) & 0.6311 & 0.6311 & 0.6311 & 0.6311 & 0.6311 \\
\hline 33 & Master Comp Mole Frac (CO) & 0.2524 & 0.2524 & 0.2524 & 0.2524 & 0.2524 \\
\hline 34 & Master Comp Mole Frac (CO2) & 0.0905 & 0.0905 & 0.0905 & 0.0905 & 0.0905 \\
\hline 35 & Master Comp Mole Frac (Methanol) & 0.0000 & 0.0000 & 0.0000 & 0.0000 & 0.0000 \\
\hline 36 & Master Comp Mole Frac (diM-Ether) & 0.0000 & 0.0000 & 0.0000 & 0.0000 & 0.0000 \\
\hline 37 & Master Comp Mole Frac (1-Propanol) & 0.0000 & 0.0000 & 0.0000 & 0.0000 & 0.0000 \\
\hline 38 & Name & 24 & 26 & 27 & 12 & COMB-PROD \\
\hline 39 & Master Comp Mole Frac $(\mathrm{H} 2 \mathrm{O})$ & 0.0260 & 0.0260 & 0.0260 & $0.0109 *$ & 0.3378 \\
\hline 40 & Master Comp Mole Frac (Oxygen) & 0.0000 & 0.0000 & 0.0000 & $0.0000 *$ & 0.0004 \\
\hline 41 & Master Comp Mole Frac (Hydrogen) & 0.6311 & 0.6311 & 0.6311 & 0.5968 * & 0.0000 \\
\hline 42 & Master Comp Mole Frac (CO) & 0.2524 & 0.2524 & 0.2524 & $0.1292 *$ & 0.0000 \\
\hline 43 & Master Comp Mole Frac (CO2) & 0.0905 & 0.0905 & 0.0905 & $0.2589 *$ & 0.6610 \\
\hline 44 & Master Comp Mole Frac (Methanol) & 0.0000 & 0.0000 & 0.0000 & $0.0041 *$ & 0.0000 \\
\hline 45 & Master Comp Mole Frac (diM-Ether) & 0.0000 & 0.0000 & 0.0000 & $0.0001 *$ & 0.0008 \\
\hline 46 & Master Comp Mole Frac (1-Propanol) & 0.0000 & 0.0000 & 0.0000 & $0.0000 *$ & 0.0000 \\
\hline 47 & Name & 28 & $\mathrm{O} 2-\mathrm{IN}-1$ & WATER-OUT-1 & CO2-OUT & COMB-PROD-2 \\
\hline 48 & Master Comp Mole Frac (H2O) & 0.3378 & $0.0000 *$ & 0.9994 & 0.0259 & 0.6666 \\
\hline 49 & Master Comp Mole Frac (Oxygen) & 0.0004 & $1.0000 *$ & 0.0000 & 0.0002 & 0.0000 \\
\hline 50 & Master Comp Mole Frac (Hydrogen) & 0.0000 & $0.0000 *$ & 0.0000 & 0.0000 & 0.0000 \\
\hline 51 & Master Comp Mole Frac (CO) & 0.0000 & $0.0000 *$ & 0.0000 & 0.0000 & 0.0000 \\
\hline 52 & Master Comp Mole Frac (CO2) & 0.6610 & $0.0000 *$ & 0.0006 & 0.9735 & 0.3333 \\
\hline 53 & Master Comp Mole Frac (Methanol) & 0.0000 & $0.0000 *$ & 0.0000 & 0.0000 & 0.0000 \\
\hline 54 & Master Comp Mole Frac (diM-Ether) & 0.0008 & $0.0000 *$ & 0.0000 & 0.0002 & 0.0000 \\
\hline 55 & Master Comp Mole Frac (1-Propanol) & 0.0000 & $0.0000 *$ & 0.0000 & 0.0001 & 0.0001 \\
\hline \begin{tabular}{|l|}
56 \\
57 \\
58 \\
59 \\
60 \\
61 \\
62 \\
\end{tabular} & & & & & & \\
\hline 63 & Honeywell International Inc. & Uni & n Design (R400 Buil & Id 16067) & & Page 6 of 12 \\
\hline
\end{tabular}




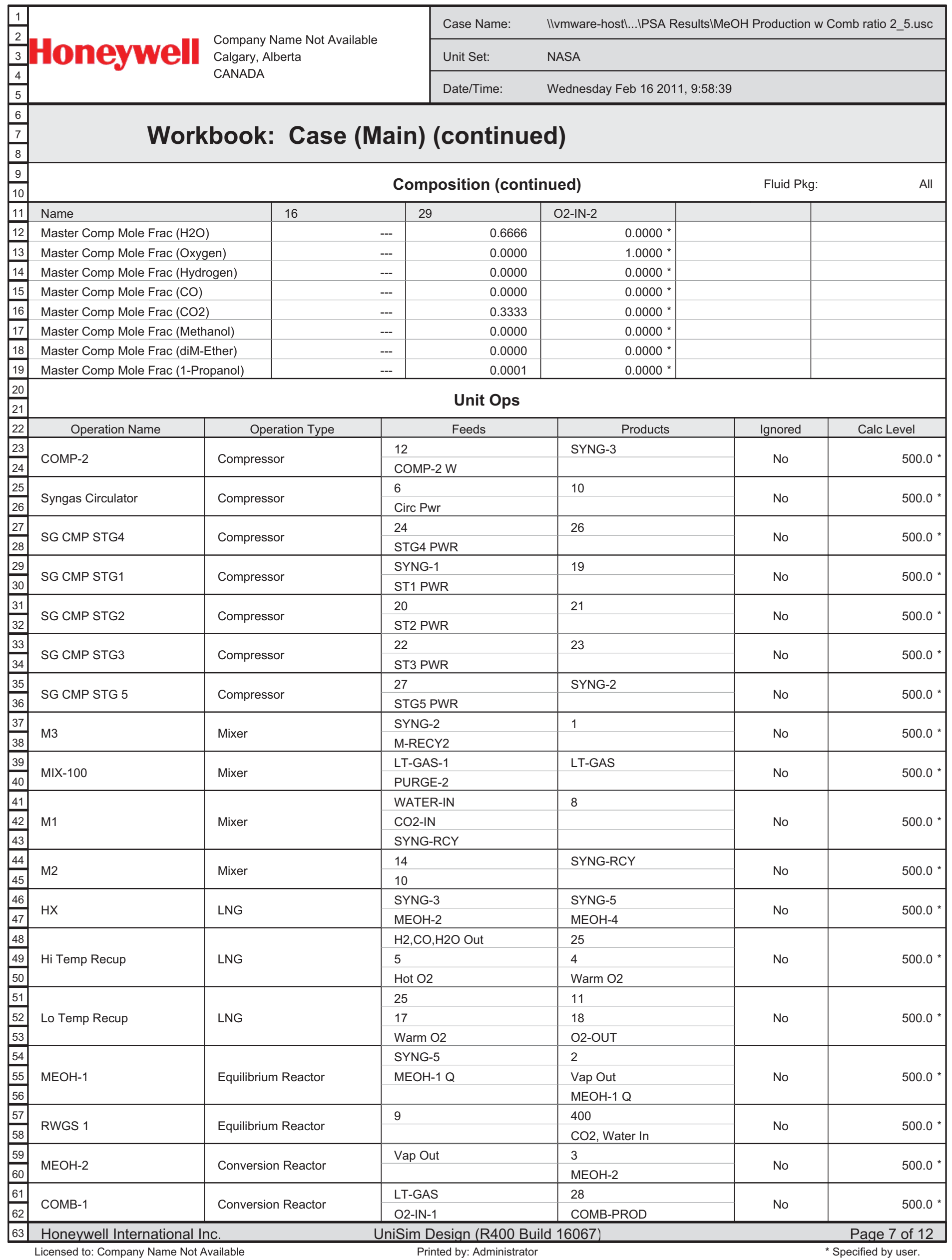




\begin{tabular}{|c|c|c|c|c|c|c|}
\hline 1 & & & Case Name: & |lvmware-hostl...IPSA & Production & $\mathrm{mb}$ ratio 2_5.usc \\
\hline 3 & Honey & Calgary, Alberta & Unit Set: & NASA & & \\
\hline$\frac{4}{5}$ & & STIVAT & Date/Time: & Wednesday Feb 1620 & & \\
\hline$\frac{6}{\frac{7}{8}}$ & Work & book: Case (N & ain) (contin & d) & & \\
\hline$\frac{9}{10}$ & & & Unit Ops (con & ued) & & \\
\hline 11 & Operation Name & Operation Type & Feeds & Products & Ignored & Calc Level \\
\hline 12 & COMB-1 & Conversion Reactor & COMB-Q-1 & COMB-Q-1 & No & $500.0^{*}$ \\
\hline 13 & & & MEOH-9 & 29 & & \\
\hline 14 & COMB-2 & Conversion Reactor & $\mathrm{O} 2-\mathrm{IN}-2$ & COMB-PROD-2 & No & 500.0 * \\
\hline 15 & & & COMB-Q-2 & COMB-Q-2 & & \\
\hline 16 & KO-DRM & Senarator & MEOH-5 & MEOH-6 & $\mathrm{No}$ & 5000 * \\
\hline 17 & KU-DRIVI & separator & & M-RECY & NO & 500.0 \\
\hline 18 & & & 7 & 13 & & \\
\hline 19 & Water Knockout Tank & Separator & Amb Q & SYNG-1 & No & 500.0 * \\
\hline 20 & & & & $\mathrm{Amb} \mathrm{Q}$ & & \\
\hline 21 & & & COMB-PROD & WATER-OUT-1 & & \\
\hline 22 & KO-DRM 2 & Separator & COMB-PROD-2 & CO2-OUT & No & $500.0 *$ \\
\hline 23 & & & AMB-Q-1 & AMB-Q-1 & & \\
\hline 24 & CONRNSR & Coolor & $\mathrm{MEOH}-4$ & MEOH-5 & $\mathrm{Ne}$ & $5000 *$ \\
\hline 25 & COINDIVSR & Cooler & & COND Q & INO & 500.0 \\
\hline 26 & INT CI R 1 & Cooler & 19 & 20 & $\mathrm{No}$ & 5000 * \\
\hline 27 & IVI CLR I & Coorer & & IC1 Q & INO & 500.0 \\
\hline 28 & INT CIR 2 & Cooler & 21 & 22 & $\mathrm{Ne}$ & 5000 * \\
\hline 29 & INVI CLR 2 & Cooler & & $\mathrm{IC} 2 \mathrm{Q}$ & INO & 500.0 \\
\hline 30 & INT CI R 3 & Cooler & 23 & 24 & $\mathrm{Ne}$ & 5000 * \\
\hline 31 & IN I CLR O & Cooler & & IC3 Q & INO & 500.0 \\
\hline 32 & INT CI R 4 & Cooler & 26 & 27 & $\mathrm{No}$ & 5000 * \\
\hline 33 & तार पूति 4 & Couter & & IC4 Q & TNo & 300.0 \\
\hline 34 & VALVE-3 & Valve & MEOH-6 & $\mathrm{MEOH}-7$ & No & 500.0 * \\
\hline 35 & VALVE-2 & Valve & PURGE-1 & PURGE-2 & No & 500.0 * \\
\hline 36 & & & MEOH-7 & MEOH-8 & & \\
\hline 37 & $\mathrm{~T}-100$ & Distillation & RB1 Q & LT-GAS-1 & No & 2500 * \\
\hline 38 & & & & CND1 Q & & \\
\hline 39 & & & MEOH-8 & WATER-OUT-2 & & \\
\hline 40 & $\mathrm{~T}-101$ & Distillation & RB2 Q & MEOH-9 & No & 2500 * \\
\hline 41 & & & & CND2 Q & & \\
\hline 42 & $\mathrm{RCY}-4$ & Recycle & 8 & 17 & No & 3500 * \\
\hline 43 & RCY-1 & Recycle & 1 & 12 & No & 3500 * \\
\hline 44 & TFF-100 & Tee & M-RECY & M-RECY2 & $\mathrm{Ne}$ & 5000 * \\
\hline 45 & TEE-IOU & 1ee & & PURGE-1 & NO & 500.0 \\
\hline 46 & T1 & Tee & 11 & 6 & $\mathrm{Ne}$ & 5000 * \\
\hline 47 & 11 & 1ee & & 7 & INO & 500.0 \\
\hline 48 & & & Sweep Gas In & Hot O2 & & \\
\hline 49 & High Temperature Co-Electrol & Standard Sub-Flowsheet & $\mathrm{CO} 2$, Water In & $\mathrm{H} 2, \mathrm{CO}, \mathrm{H} 2 \mathrm{O}$ Out & No & 2500 * \\
\hline 50 & Hign lemperature co-Electrol & Standard Sub-Flowsheet & Process Heat & & No & 2500 \\
\hline 51 & & & Electrolysis Power & & & \\
\hline 52 & Tonning Heat & Heater & 4 & 9 & $\mathrm{No}$ & 5000 * \\
\hline 53 & 10pping neat & Hedel & Top Heat Q & & TNO & 500.0 \\
\hline 54 & Preheater & Heater & 18 & 5 & $\mathrm{No}$ & 5000 * \\
\hline 55 & Preneater & Heater & Preheat Q & & No & 500.0 \\
\hline 56 & SPRDSHT-1 & Spreadsheet & & & No & 500.0 * \\
\hline 57 & Water Pump & Pump & 13 & 14 & No & $500.0 *$ \\
\hline 58 & Water Pump & Pump & Water Pump Pwr & & No & $500.0^{*}$ \\
\hline 59 & & & & & & \\
\hline 60 & & & & & & \\
\hline 61 & & & & & & \\
\hline 62 & & & & & & \\
\hline 63 & Honeywell International In & c. & niSim Design (R400 & Id 16067) & & Page 8 of 12 \\
\hline
\end{tabular}




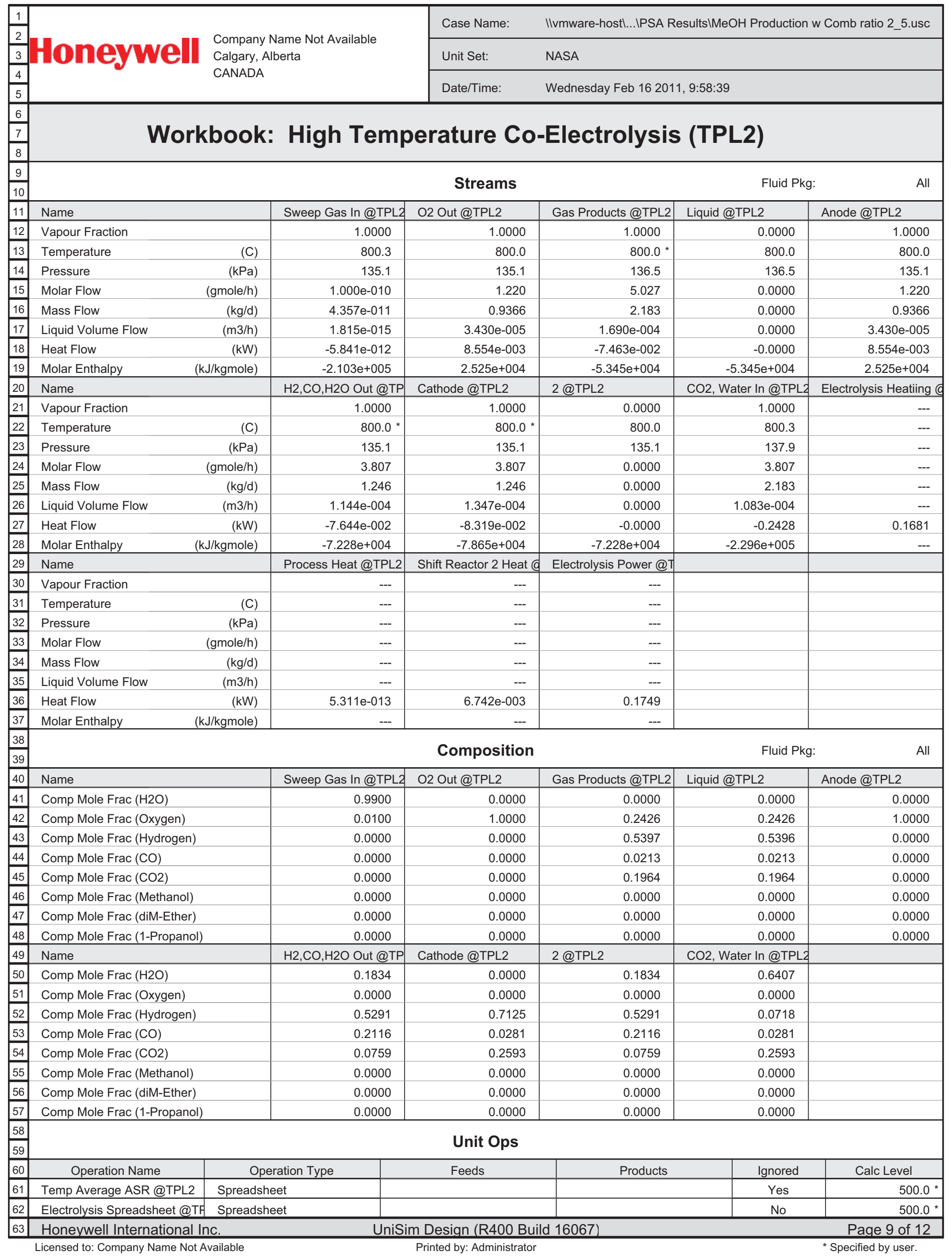




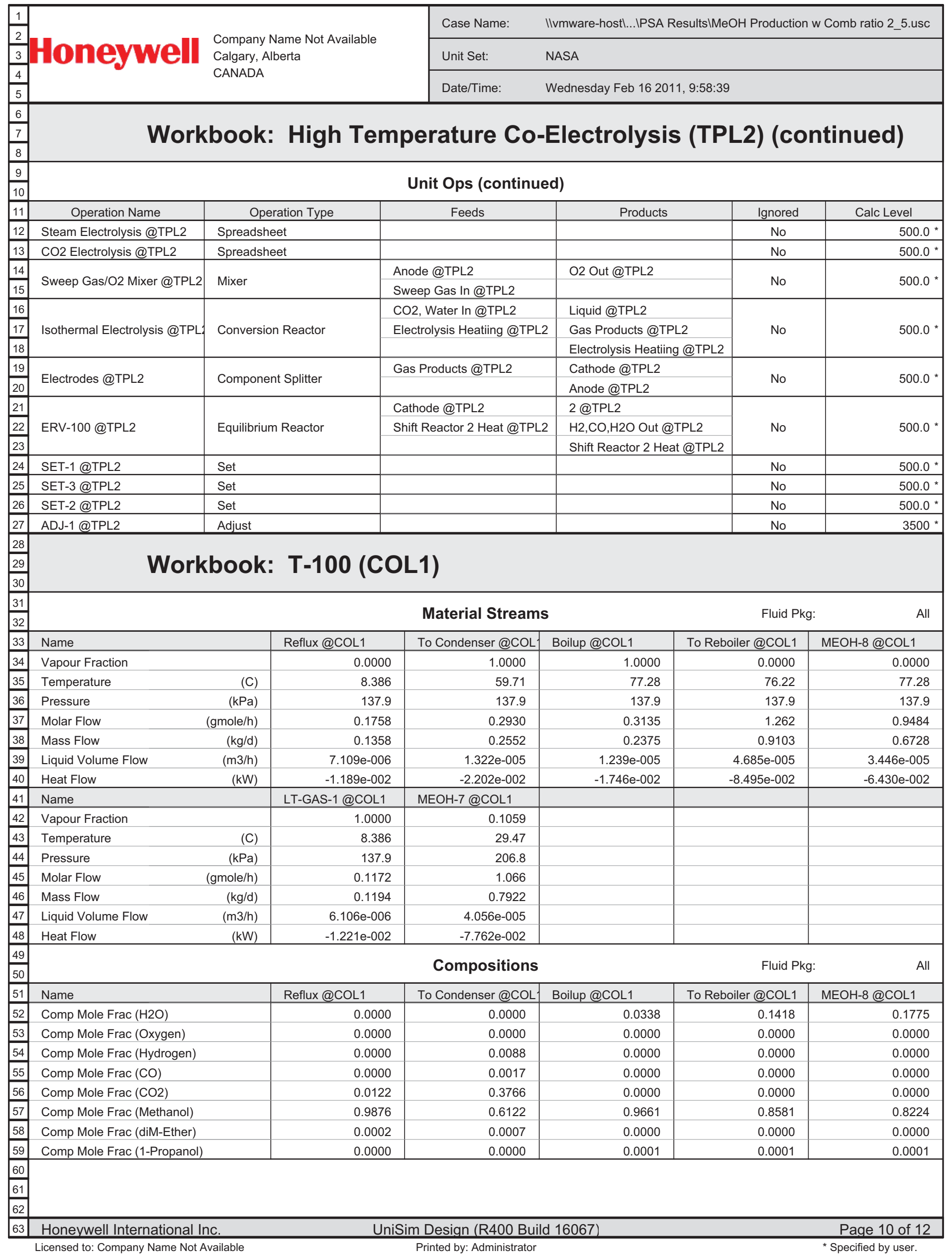




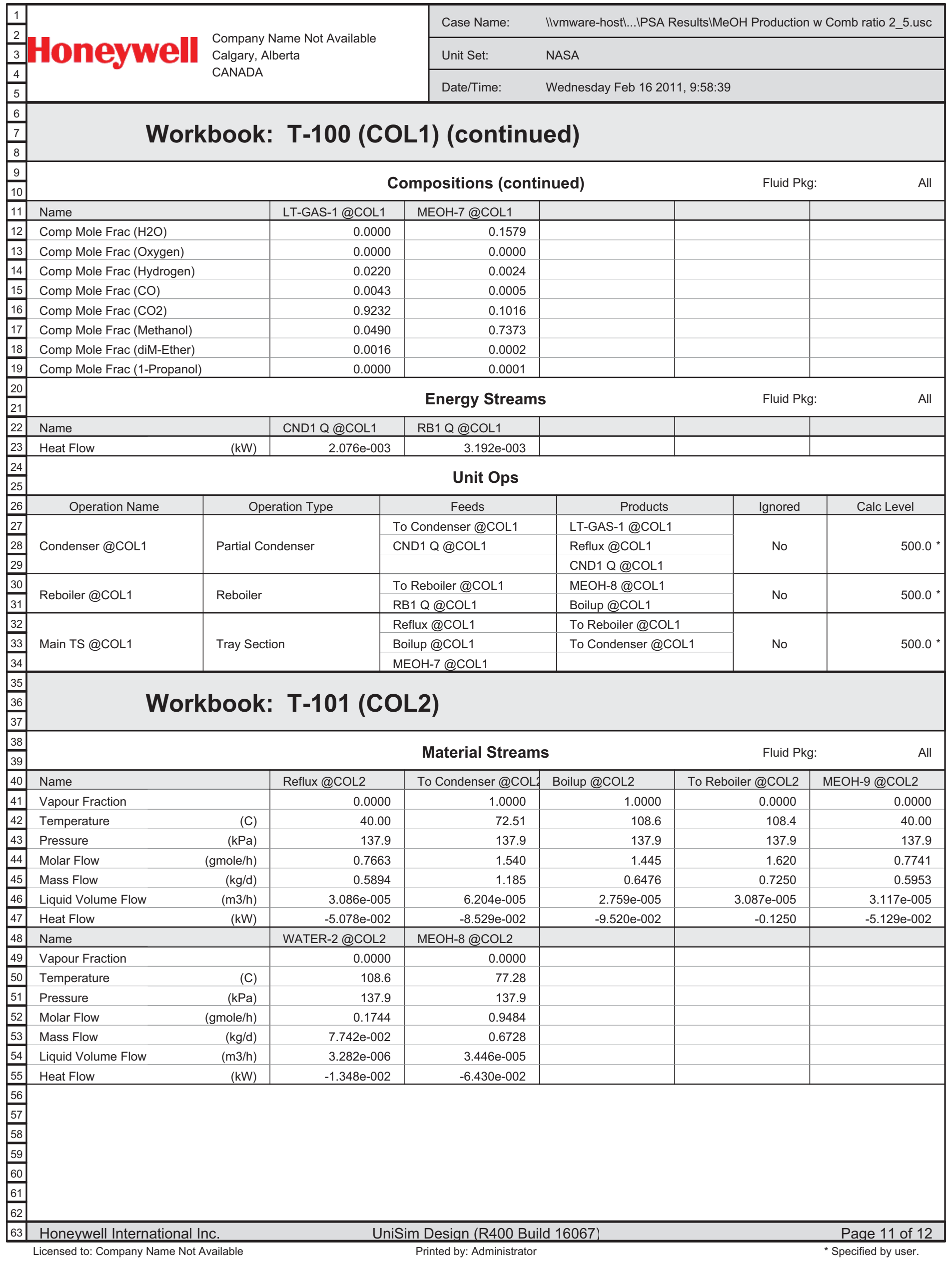




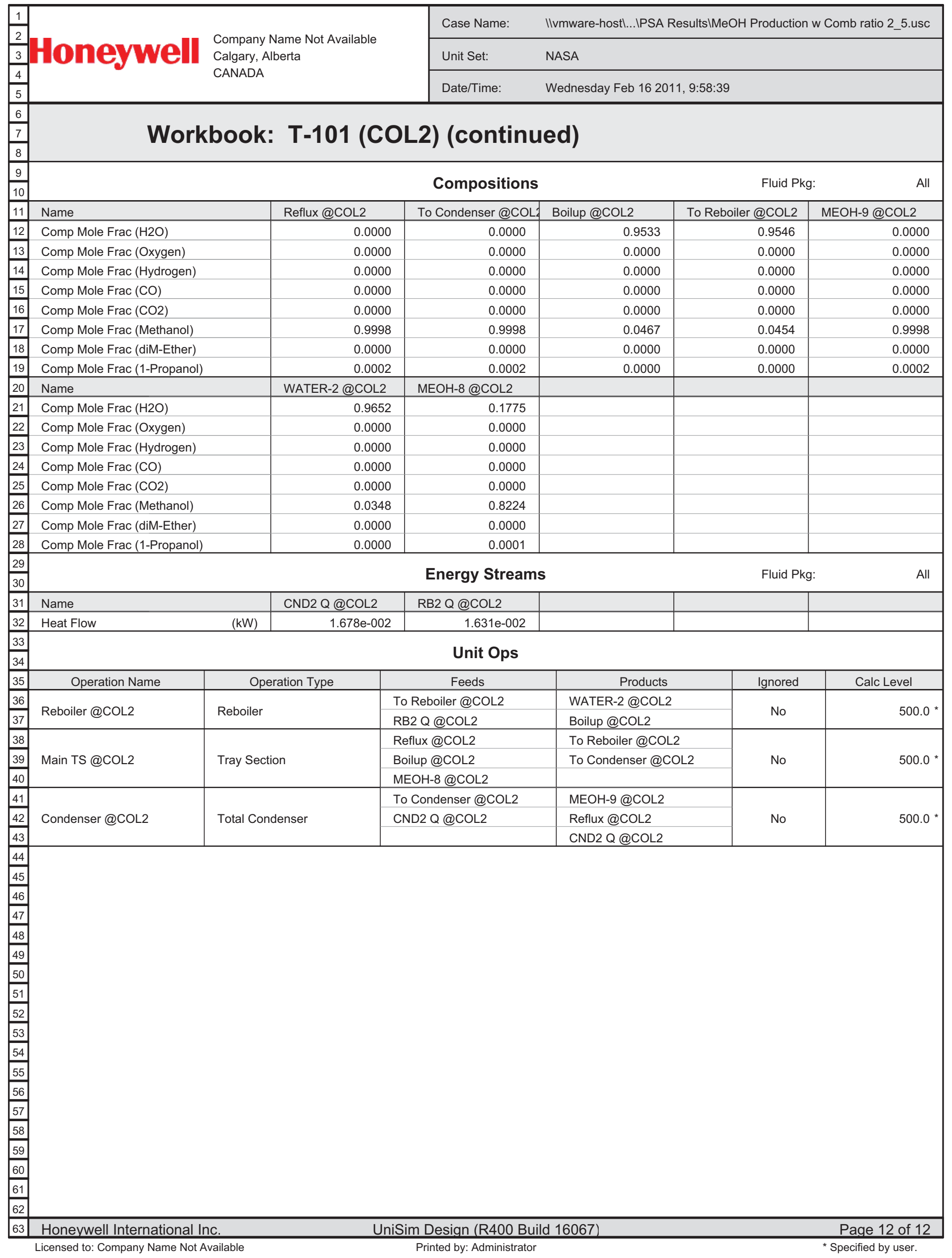




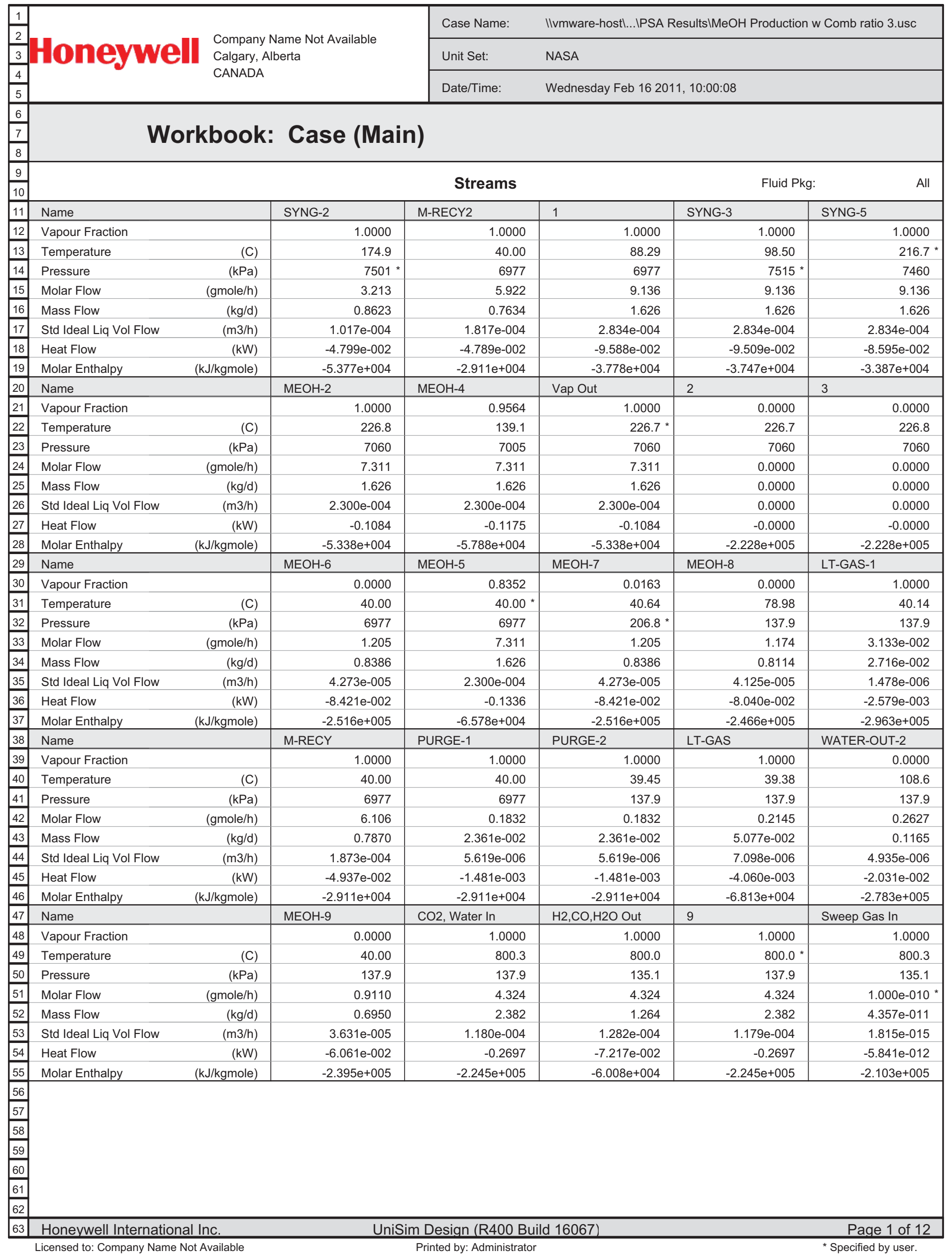




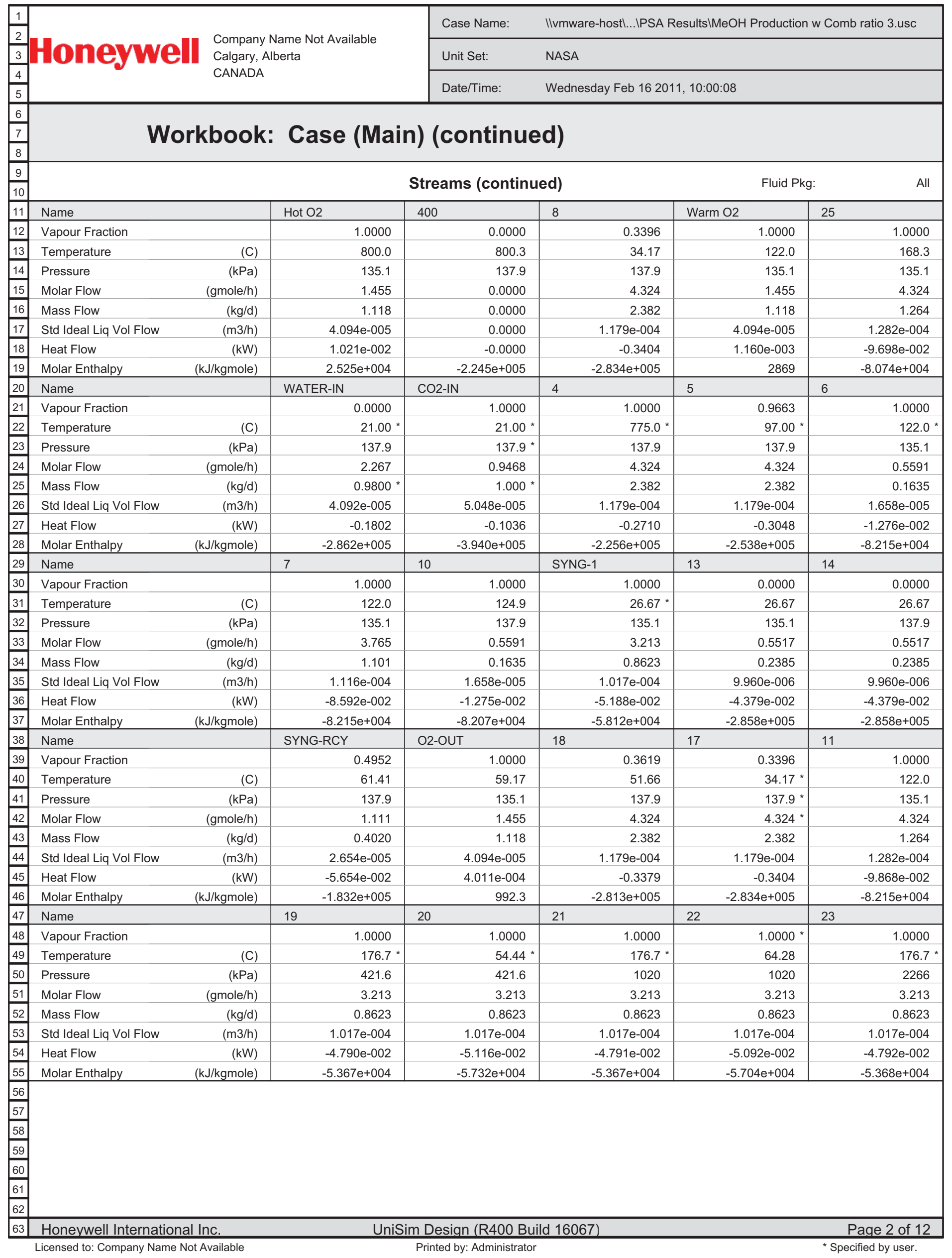




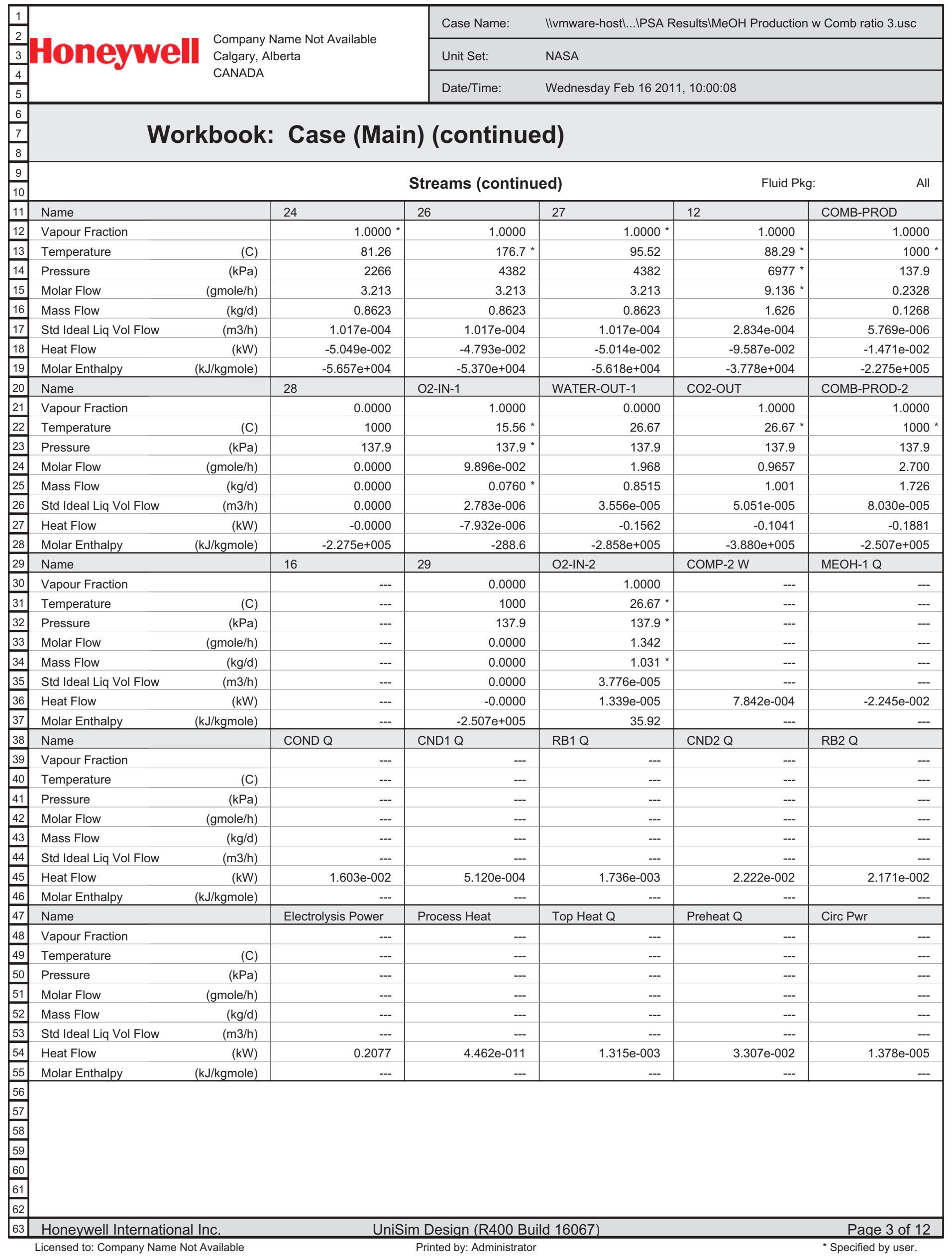




\begin{tabular}{|c|c|c|c|c|c|c|}
\hline 1 & \multirow{3}{*}{\multicolumn{2}{|c|}{$\begin{array}{l}\text { Company Name Not Available } \\
\text { Calgary, Alberta } \\
\text { CANADA }\end{array}$}} & \multirow{2}{*}{$\begin{array}{l}\text { Case Name: } \\
\text { Unit Set: }\end{array}$} & \multicolumn{3}{|c|}{ |lvmware-hostl...IPSA ResultsIMeOH Production w Comb ratio 3.usc } \\
\hline 3 & & & & \multicolumn{3}{|l|}{ NASA } \\
\hline$\frac{4}{5}$ & & & Date/Time: & \multicolumn{3}{|c|}{ Wednesday Feb 16 2011, 10:00:08 } \\
\hline$\frac{6}{\frac{7}{8}}$ & \multicolumn{6}{|c|}{ Workbook: Case (Main) (continued) } \\
\hline$\frac{9}{10}$ & \multicolumn{4}{|c|}{ Streams (continued) } & \multicolumn{2}{|c|}{ Fluid Pkg: } \\
\hline 11 & Name & Amb Q & Water Pump Pwr & ST1 PWR & IC1 Q & $\mathrm{IC} 2 \mathrm{Q}$ \\
\hline 12 & Vapour Fraction & --- & 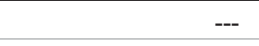 & --- & --- & --- \\
\hline 13 & Temperature & --- & --- & --- & --- & --- \\
\hline 14 & Pressure & --- & --- & --- & --- & -- \\
\hline 15 & Molar Flow & -- & --- & --- & --- & -- \\
\hline 16 & Mass Flow & -- & --- & --- & --- & -- \\
\hline 17 & Std Ideal Liq Vol Flow & --- & --- & --- & --- & --- \\
\hline 18 & Heat Flow & $-9.754 \mathrm{e}-003$ & $1.009 \mathrm{e}-008$ & $3.980 \mathrm{e}-003$ & $3.258 \mathrm{e}-003$ & $3.009 e-003$ \\
\hline 19 & Molar Enthalpy & --- & --- & --- & --- & -- \\
\hline 20 & Name & ST2 PWR & ST3 PWR & IC3 Q & STG4 PWR & IC4 Q \\
\hline 21 & Vapour Fraction & --- & --- & --- & --- & -- \\
\hline 22 & Temperature & --- & --- & --- & --- & --- \\
\hline 23 & Pressure & --- & --- & --- & --- & -- \\
\hline 24 & Molar Flow & --- & --- & --- & --- & -- \\
\hline 25 & Mass Flow & --- & --- & --- & --- & -- \\
\hline 26 & Std Ideal Liq Vol Flow & --- & --- & -- & --- & -- \\
\hline 27 & Heat Flow & $3.254 \mathrm{e}-003$ & $3.001 \mathrm{e}-003$ & $2.576 \mathrm{e}-003$ & $2.562 \mathrm{e}-003$ & $2.215 e-003$ \\
\hline 28 & Molar Enthalpy & --- & --- & --- & --- & -- \\
\hline 29 & Name & STG5 PWR & COMB-Q-1 & AMB-Q-1 & COMB-Q-2 & \\
\hline 30 & Vapour Fraction & -- & --- & --- & --- & \\
\hline 31 & Temperature & --- & --- & --- & --- & \\
\hline 32 & Pressure & --- & --- & --- & --- & \\
\hline 33 & Molar Flow & -- & --- & --- & --- & \\
\hline 34 & Mass Flow & --- & --- & --- & --- & \\
\hline 35 & Std Ideal Liq Vol Flow & -- & --- & -- & -- & \\
\hline 36 & Heat Flow & $2.152 \mathrm{e}-003$ & $-1.065 e-002$ & $-5.750 e-002$ & -0.1275 & \\
\hline 37 & Molar Enthalpy & --- & --- & --- & --- & \\
\hline 38 & \multicolumn{4}{|c|}{ Composition } & \multicolumn{2}{|c|}{ Fluid Pkg: } \\
\hline 40 & Name & SYNG-2 & M-RECY2 & 1 & SYNG-3 & SYNG-5 \\
\hline 41 & Master Comp Mole Frac (H2O) & 0.0260 & 0.0003 & 0.0093 & 0.0093 & 0.0093 \\
\hline 42 & Master Comp Mole Frac (Oxygen) & 0.0000 & 0.0000 & 0.0000 & 0.0000 & 0.0000 \\
\hline 43 & Master Comp Mole Frac (Hydrogen) & 0.6794 & 0.9142 & 0.8316 & 0.8316 & 0.8316 \\
\hline 44 & Master Comp Mole Frac (CO) & 0.2265 & 0.0112 & 0.0869 & 0.0869 & 0.0869 \\
\hline 45 & Master Comp Mole Frac (CO2) & 0.0681 & 0.0690 & 0.0687 & 0.0687 & 0.0687 \\
\hline 46 & Master Comp Mole Frac (Methanol) & 0.0000 & 0.0051 & 0.0033 & 0.0033 & 0.0033 \\
\hline 47 & Master Comp Mole Frac (diM-Ether) & 0.0000 & 0.0002 & 0.0001 & 0.0001 & 0.0001 \\
\hline 48 & Master Comp Mole Frac (1-Propanol) & 0.0000 & 0.0000 & 0.0000 & 0.0000 & 0.0000 \\
\hline 49 & Name & MEOH-2 & $\mathrm{MEOH}-4$ & Vap Out & 2 & 3 \\
\hline 50 & Master Comp Mole Frac (H2O) & 0.0373 & 0.0373 & 0.0372 & 0.3201 & 0.3206 \\
\hline 51 & Master Comp Mole Frac (Oxygen) & 0.0000 & 0.0000 & 0.0000 & 0.0000 & 0.0000 \\
\hline 52 & Master Comp Mole Frac (Hydrogen) & 0.7640 & 0.7640 & 0.7640 & 0.0534 & 0.0535 \\
\hline 53 & Master Comp Mole Frac (CO) & 0.0094 & 0.0094 & 0.0094 & 0.0008 & 0.0008 \\
\hline 54 & Master Comp Mole Frac (CO2) & 0.0602 & 0.0602 & 0.0602 & 0.0205 & 0.0205 \\
\hline 55 & Master Comp Mole Frac (Methanol) & 0.1289 & 0.1289 & 0.1290 & 0.6050 & 0.6043 \\
\hline 56 & Master Comp Mole Frac (diM-Ether) & 0.0002 & 0.0002 & 0.0002 & 0.0001 & 0.0002 \\
\hline 57 & Master Comp Mole Frac (1-Propanol) & 0.0000 & 0.0000 & 0.0000 & 0.0000 & 0.0001 \\
\hline \begin{tabular}{|l|}
58 \\
59 \\
60 \\
61 \\
62 \\
\end{tabular} & & & & & & \\
\hline 63 & Honeywell International Inc. & Unis & n Design (R400 Bu & (d 16067) & & Page 4 of 12 \\
\hline
\end{tabular}




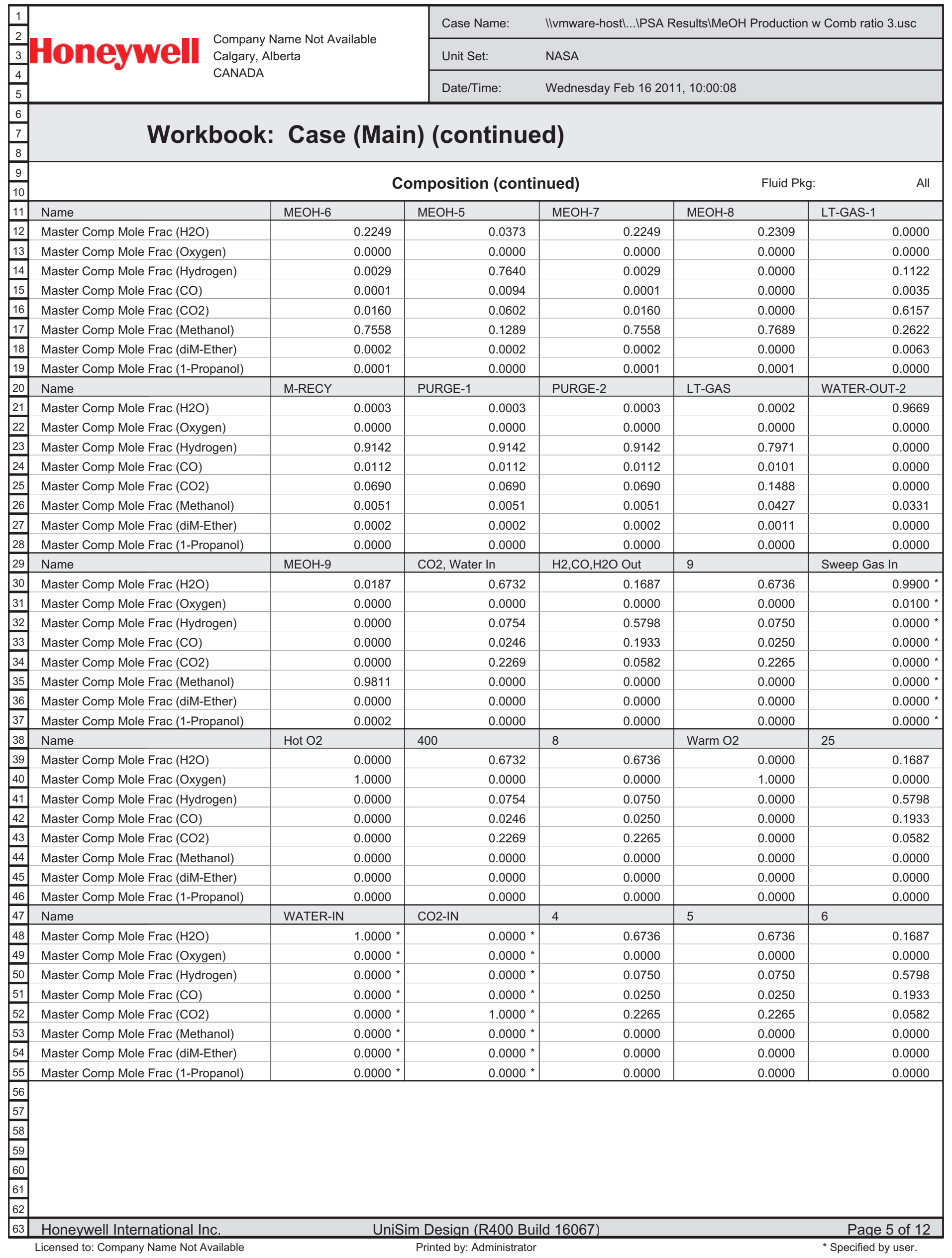




\begin{tabular}{|c|c|c|c|c|c|c|}
\hline 1 & & & Case Name: & IIvmware-hostl...IPSA & esults $\mid \mathrm{MeOH}$ Production & w Comb ratio $3 . u s c$ \\
\hline 3 & DOCNWE Calgar & perta & Unit Set: & NASA & & \\
\hline$\frac{7}{5}$ & URIVI & & Date/Time: & Wednesday Feb 1620 & $1,10: 00: 08$ & \\
\hline$\frac{6}{\frac{7}{8}}$ & Workboo & Case (Ma & ) (continue & d) & & \\
\hline$\frac{9}{10}$ & & & mposition (contir & hued) & Fluid Pkg & All \\
\hline 11 & Name & 7 & 10 & SYNG-1 & 13 & 14 \\
\hline 12 & Master Comp Mole Frac $(\mathrm{H} 2 \mathrm{O})$ & 0.1687 & 0.1687 & 0.0260 & 0.9999 & 0.9999 \\
\hline 13 & Master Comp Mole Frac (Oxygen) & 0.0000 & 0.0000 & 0.0000 & 0.0000 & 0.0000 \\
\hline 14 & Master Comp Mole Frac (Hydrogen) & 0.5798 & 0.5798 & 0.6794 & 0.0001 & 0.0001 \\
\hline 15 & Master Comp Mole Frac (CO) & 0.1933 & 0.1933 & 0.2265 & 0.0000 & 0.0000 \\
\hline 16 & Master Comp Mole Frac (CO2) & 0.0582 & 0.0582 & 0.0681 & 0.0000 & 0.0000 \\
\hline 17 & Master Comp Mole Frac (Methanol) & 0.0000 & 0.0000 & 0.0000 & 0.0000 & 0.0000 \\
\hline 18 & Master Comp Mole Frac (diM-Ether) & 0.0000 & 0.0000 & 0.0000 & 0.0000 & 0.0000 \\
\hline 19 & Master Comp Mole Frac (1-Propanol) & 0.0000 & 0.0000 & 0.0000 & 0.0000 & 0.0000 \\
\hline 20 & Name & SYNG-RCY & O2-OUT & 18 & 17 & 11 \\
\hline 21 & Master Comp Mole Frac $(\mathrm{H} 2 \mathrm{O})$ & 0.5815 & 0.0000 & 0.6736 & $0.6736^{*}$ & 0.1687 \\
\hline 22 & Master Comp Mole Frac (Oxygen) & 0.0000 & 1.0000 & 0.0000 & $0.0000 *$ & 0.0000 \\
\hline 23 & Master Comp Mole Frac (Hydrogen) & 0.2919 & 0.0000 & 0.0750 & $0.0750 *$ & 0.5798 \\
\hline 24 & Master Comp Mole Frac (CO) & 0.0973 & 0.0000 & 0.0250 & $0.0250 *$ & 0.1933 \\
\hline 25 & Master Comp Mole Frac (CO2) & 0.0293 & 0.0000 & 0.2265 & $0.2265 *$ & 0.0582 \\
\hline 26 & Master Comp Mole Frac (Methanol) & 0.0000 & 0.0000 & 0.0000 & $0.0000 *$ & 0.0000 \\
\hline 27 & Master Comp Mole Frac (diM-Ether) & 0.0000 & 0.0000 & 0.0000 & $0.0000 *$ & 0.0000 \\
\hline 28 & Master Comp Mole Frac (1-Propanol) & 0.0000 & 0.0000 & 0.0000 & $0.0000 *$ & 0.0000 \\
\hline 29 & Name & 19 & 20 & 21 & 22 & 23 \\
\hline 30 & Master Comp Mole Frac (H2O) & 0.0260 & 0.0260 & 0.0260 & 0.0260 & 0.0260 \\
\hline 31 & Master Comp Mole Frac (Oxygen) & 0.0000 & 0.0000 & 0.0000 & 0.0000 & 0.0000 \\
\hline 32 & Master Comp Mole Frac (Hydrogen) & 0.6794 & 0.6794 & 0.6794 & 0.6794 & 0.6794 \\
\hline 33 & Master Comp Mole Frac (CO) & 0.2265 & 0.2265 & 0.2265 & 0.2265 & 0.2265 \\
\hline 34 & Master Comp Mole Frac (CO2) & 0.0681 & 0.0681 & 0.0681 & 0.0681 & 0.0681 \\
\hline 35 & Master Comp Mole Frac (Methanol) & 0.0000 & 0.0000 & 0.0000 & 0.0000 & 0.0000 \\
\hline 36 & Master Comp Mole Frac (diM-Ether) & 0.0000 & 0.0000 & 0.0000 & 0.0000 & 0.0000 \\
\hline 37 & Master Comp Mole Frac (1-Propanol) & 0.0000 & 0.0000 & 0.0000 & 0.0000 & 0.0000 \\
\hline 38 & Name & 24 & 26 & 27 & 12 & COMB-PROD \\
\hline 39 & Master Comp Mole Frac $(\mathrm{H} 2 \mathrm{O})$ & 0.0260 & 0.0260 & 0.0260 & $0.0093 *$ & 0.8018 \\
\hline 40 & Master Comp Mole Frac (Oxygen) & 0.0000 & 0.0000 & 0.0000 & $0.0000 *$ & 0.0000 \\
\hline 41 & Master Comp Mole Frac (Hydrogen) & 0.6794 & 0.6794 & 0.6794 & $0.8316 *$ & 0.0115 \\
\hline 42 & Master Comp Mole Frac (CO) & 0.2265 & 0.2265 & 0.2265 & $0.0869 *$ & 0.0000 \\
\hline 43 & Master Comp Mole Frac (CO2) & 0.0681 & 0.0681 & 0.0681 & $0.0687 *$ & 0.1857 \\
\hline 44 & Master Comp Mole Frac (Methanol) & 0.0000 & 0.0000 & 0.0000 & $0.0033 *$ & 0.0000 \\
\hline 45 & Master Comp Mole Frac (diM-Ether) & 0.0000 & 0.0000 & 0.0000 & $0.0001 *$ & 0.0010 \\
\hline 46 & Master Comp Mole Frac (1-Propanol) & 0.0000 & 0.0000 & 0.0000 & $0.0000 *$ & 0.0000 \\
\hline 47 & Name & 28 & $\mathrm{O} 2-\mathrm{IN}-1$ & WATER-OUT-1 & CO2-OUT & COMB-PROD-2 \\
\hline 48 & Master Comp Mole Frac (H2O) & 0.8018 & $0.0000 *$ & 0.9994 & 0.0259 & 0.6683 \\
\hline 49 & Master Comp Mole Frac (Oxygen) & 0.0000 & $1.0000 *$ & 0.0000 & 0.0018 & 0.0007 \\
\hline 50 & Master Comp Mole Frac (Hydrogen) & 0.0115 & $0.0000 *$ & 0.0000 & 0.0028 & 0.0000 \\
\hline 51 & Master Comp Mole Frac (CO) & 0.0000 & $0.0000 *$ & 0.0000 & 0.0000 & 0.0000 \\
\hline 52 & Master Comp Mole Frac (CO2) & 0.1858 & $0.0000 *$ & 0.0006 & 0.9691 & 0.3310 \\
\hline 53 & Master Comp Mole Frac (Methanol) & 0.0000 & $0.0000 *$ & 0.0000 & 0.0000 & 0.0000 \\
\hline 54 & Master Comp Mole Frac (diM-Ether) & 0.0010 & $0.0000 *$ & 0.0000 & 0.0002 & 0.0000 \\
\hline 55 & Master Comp Mole Frac (1-Propanol) & 0.0000 & $0.0000 *$ & 0.0000 & 0.0002 & 0.0001 \\
\hline \begin{tabular}{|l|}
56 \\
57 \\
58 \\
59 \\
60 \\
61 \\
62 \\
\end{tabular} & & & & & & \\
\hline 63 & Honeywell International Inc. & Uni & n Design (R400 Buil & Id 16067) & & Page 6 of 12 \\
\hline
\end{tabular}




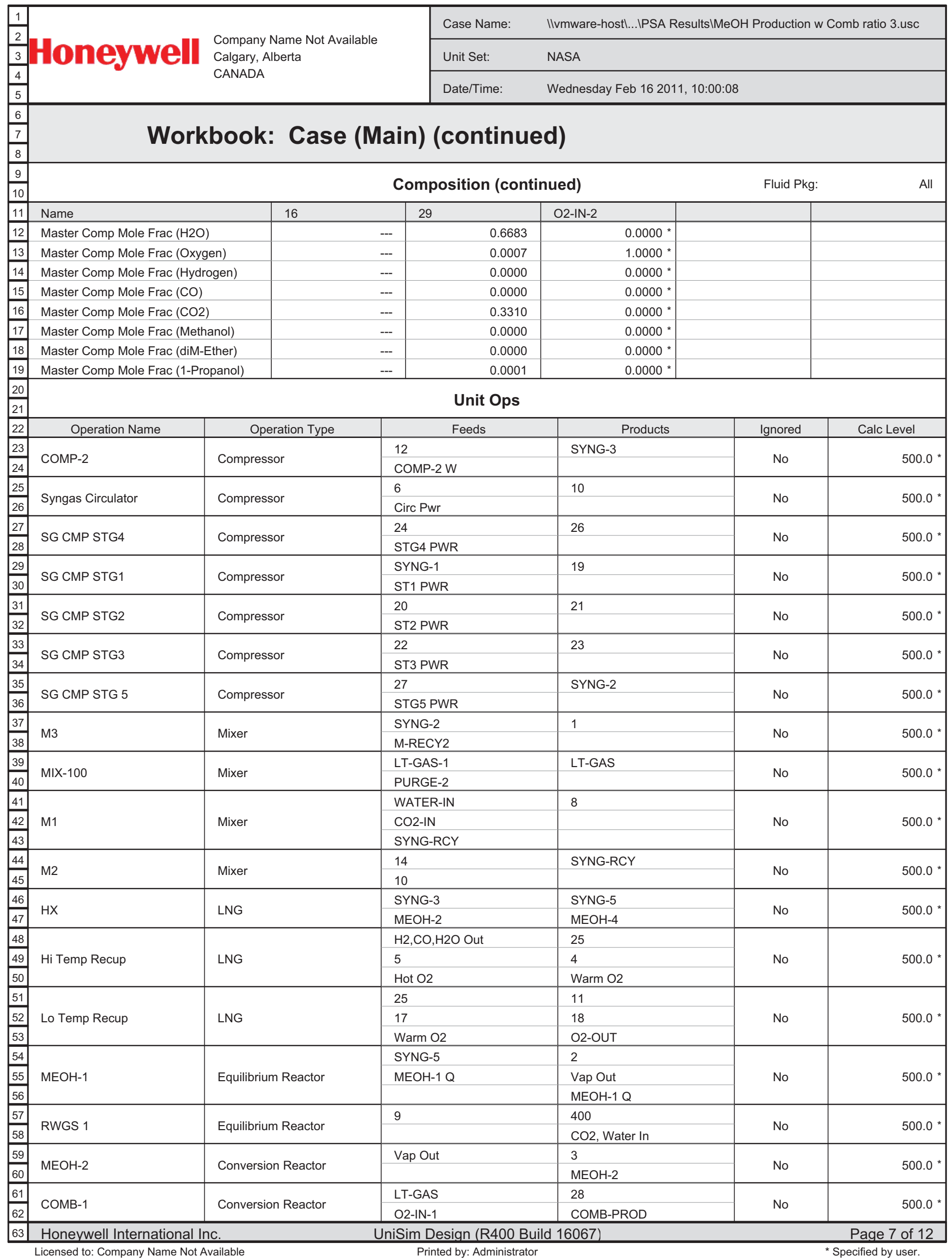




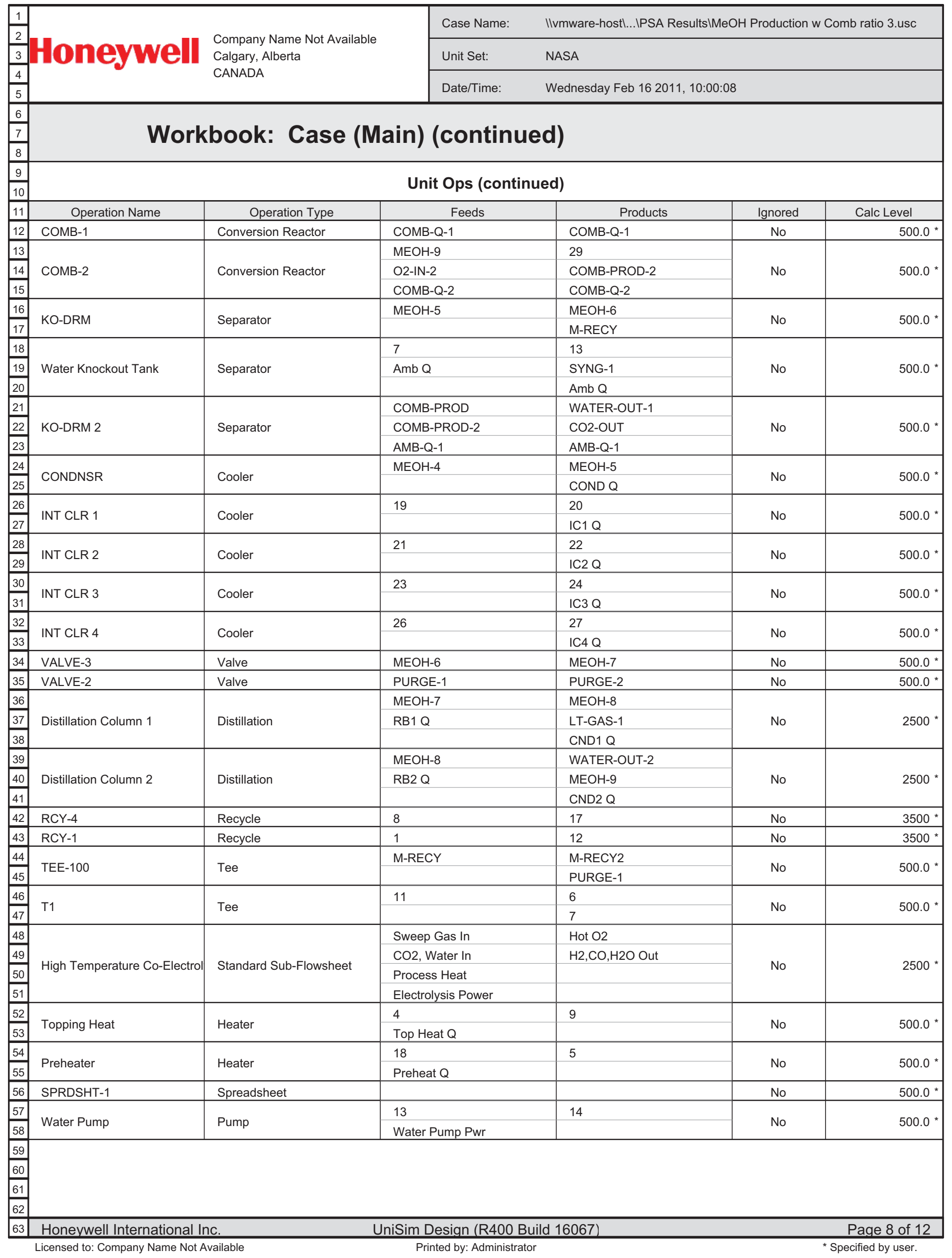




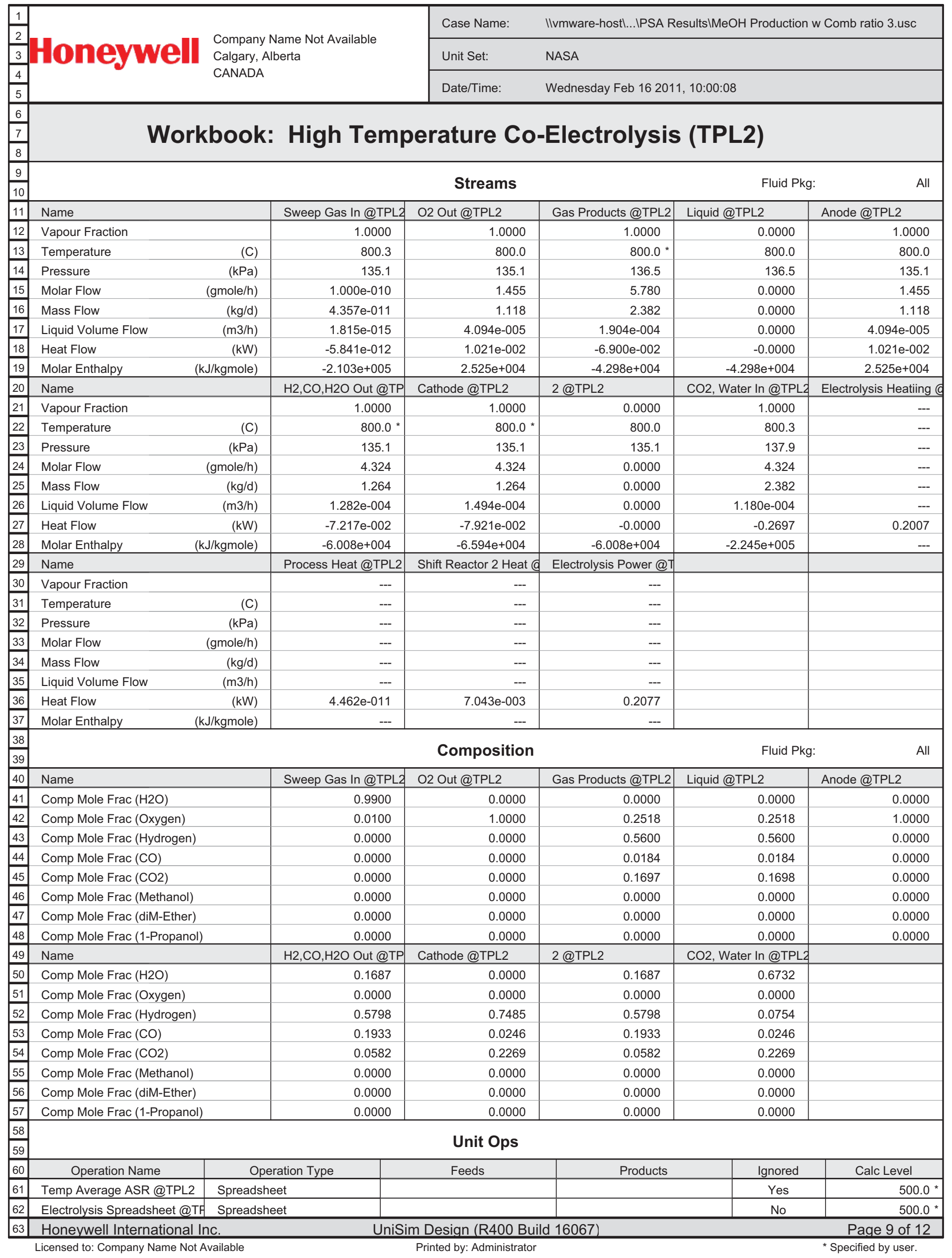




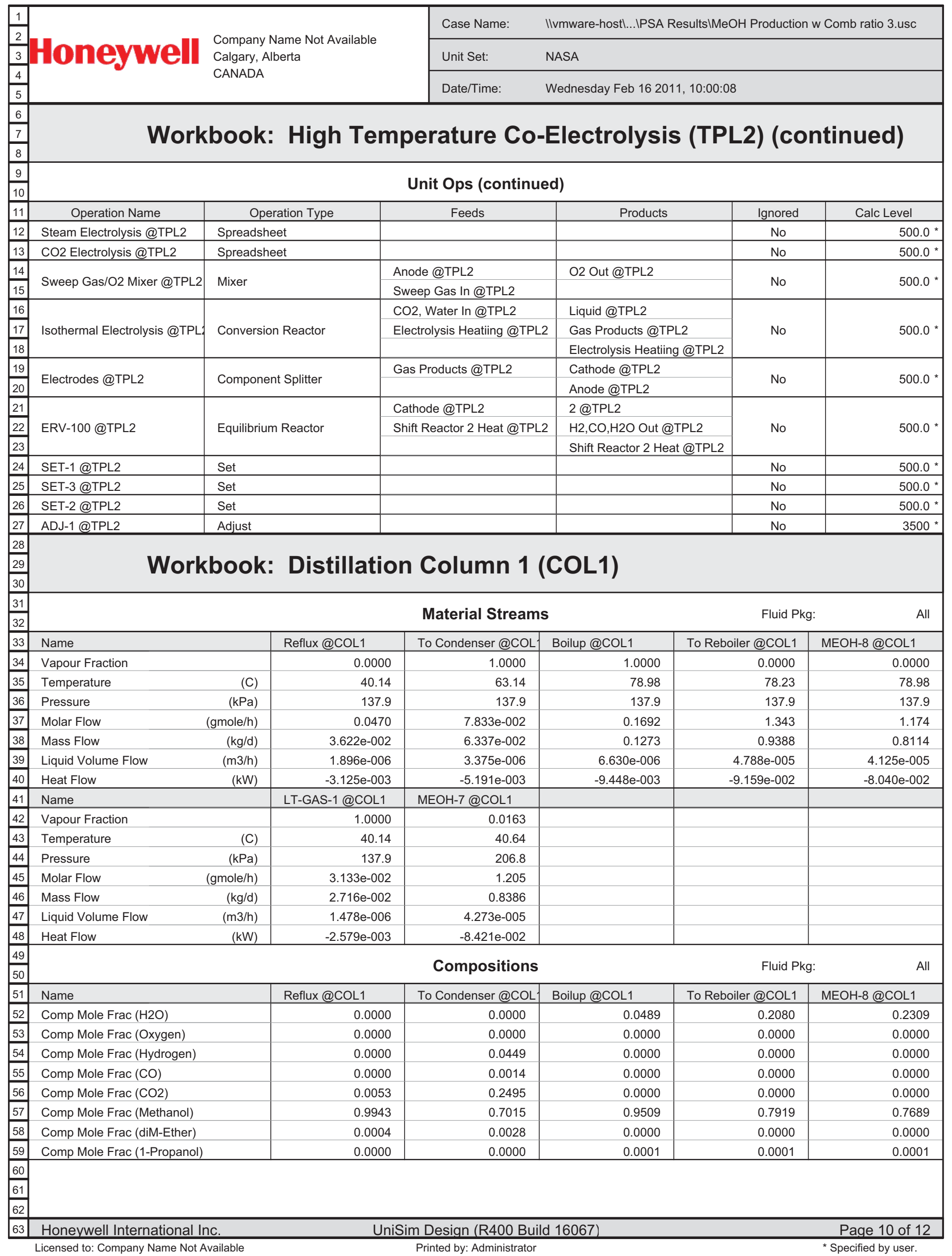




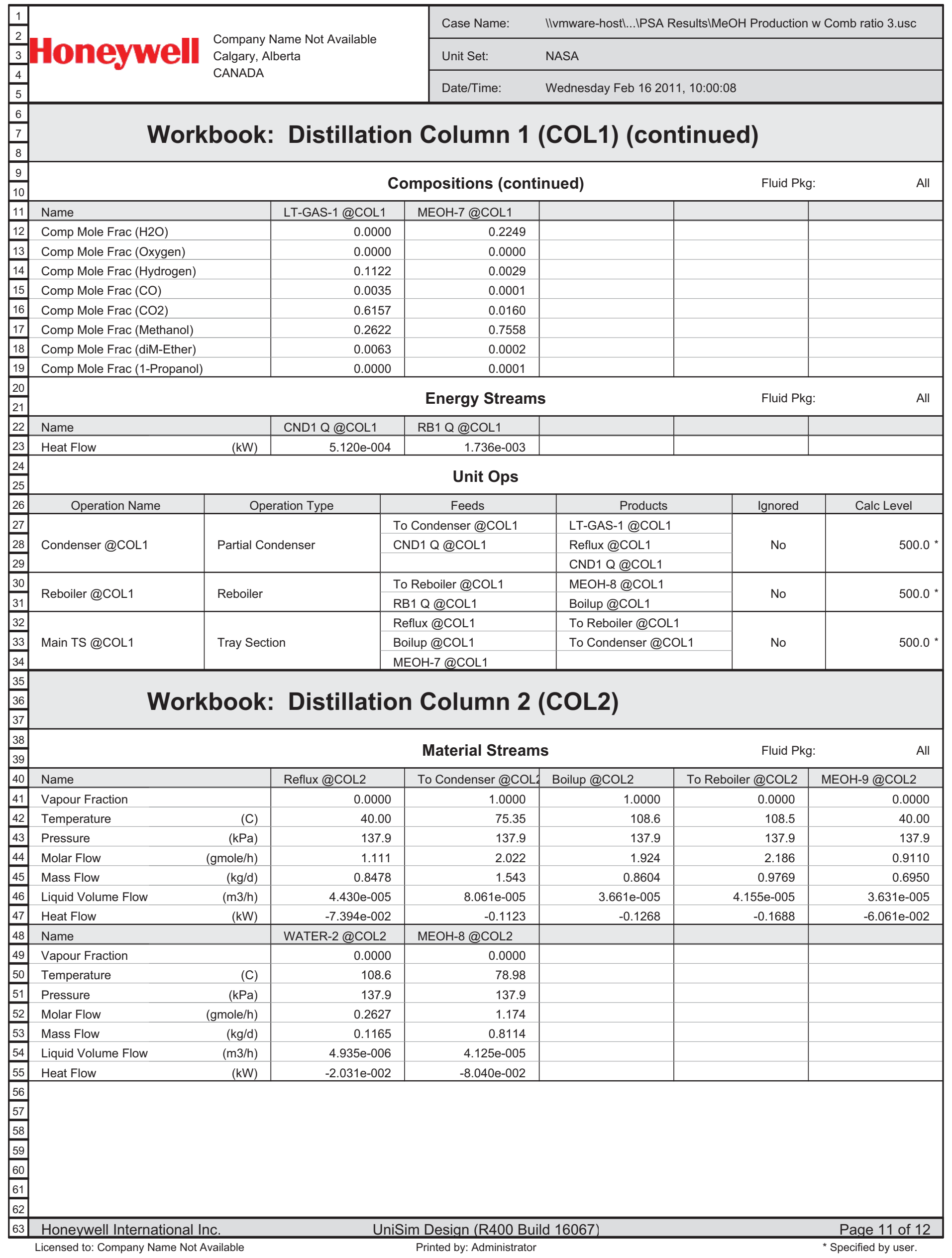




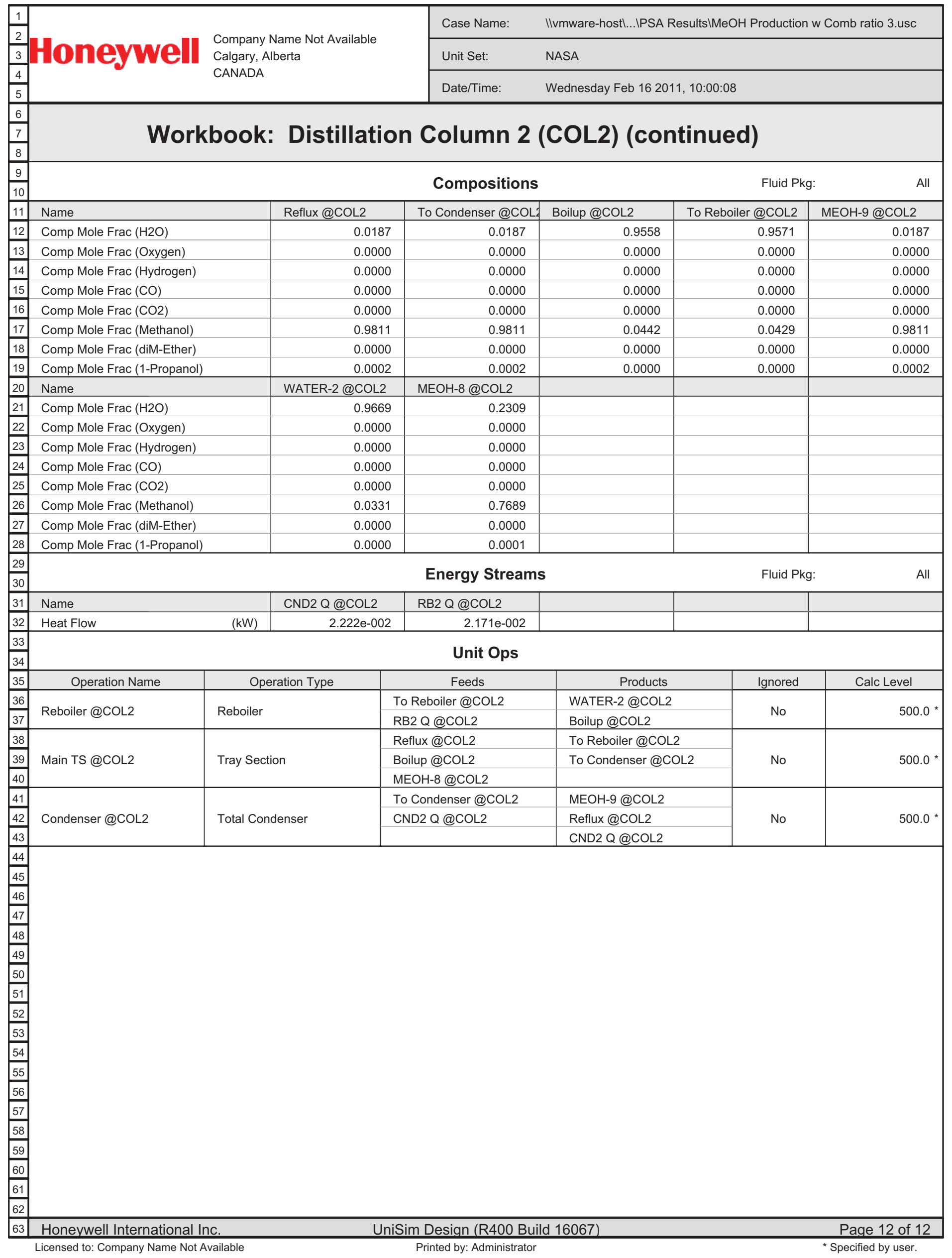




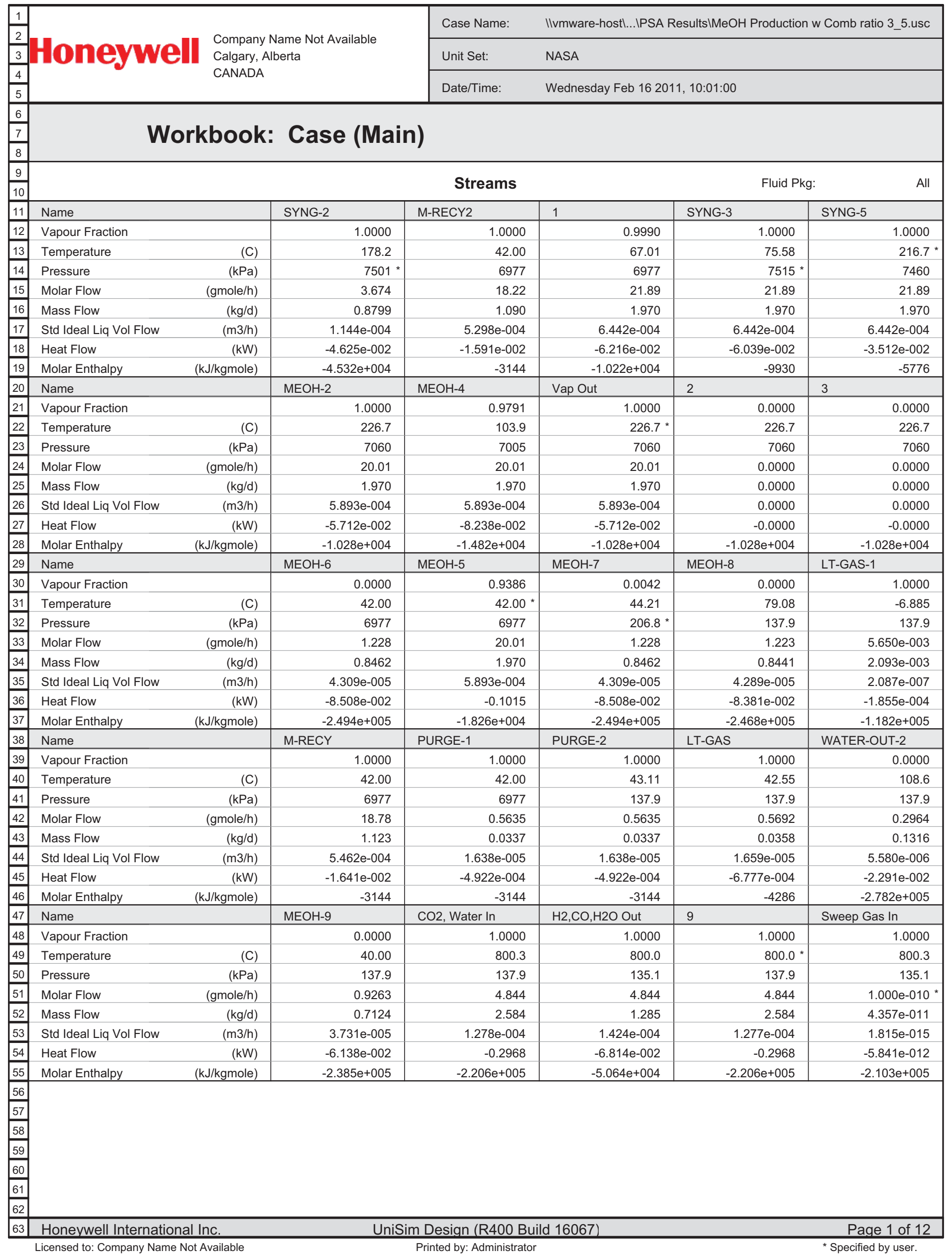




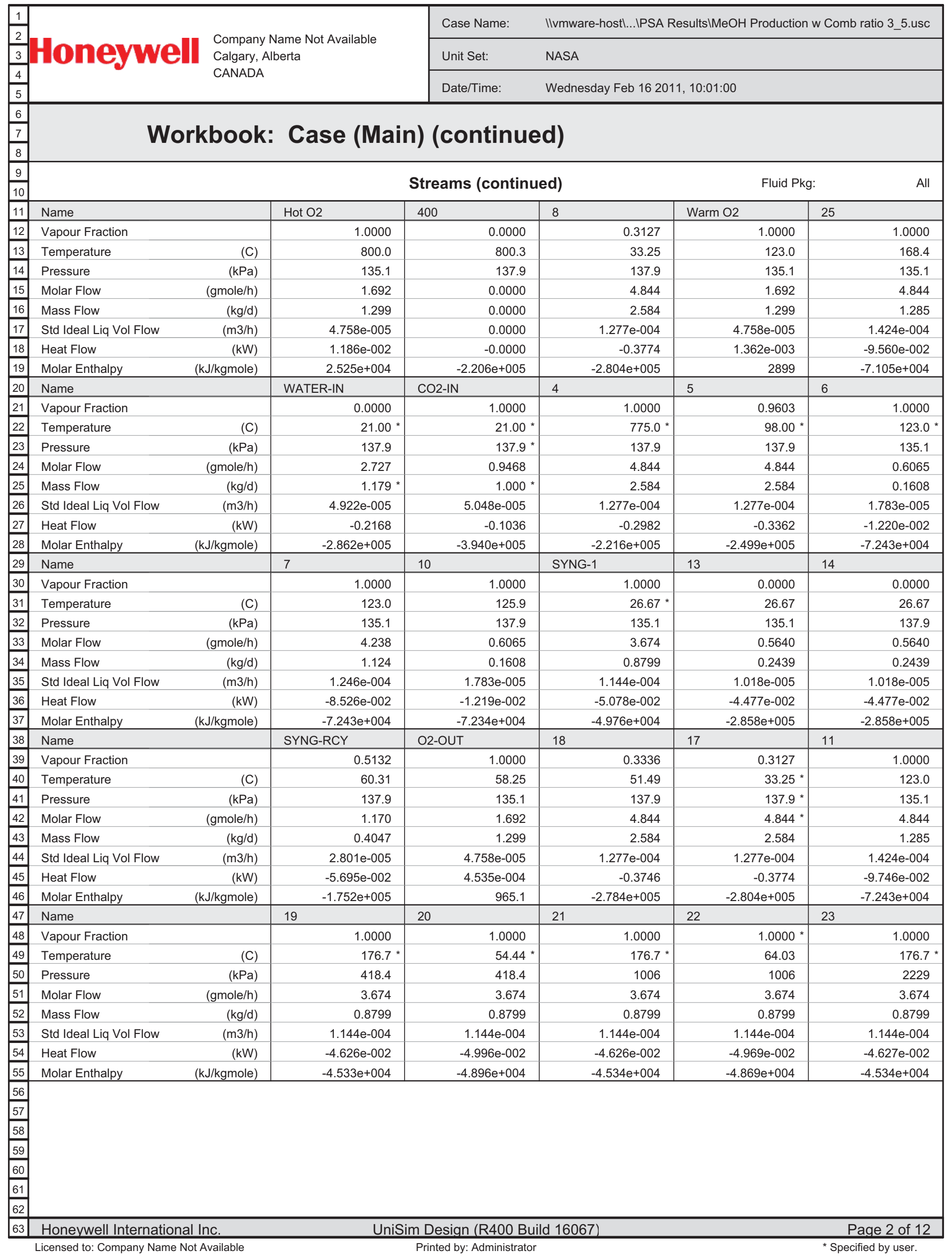




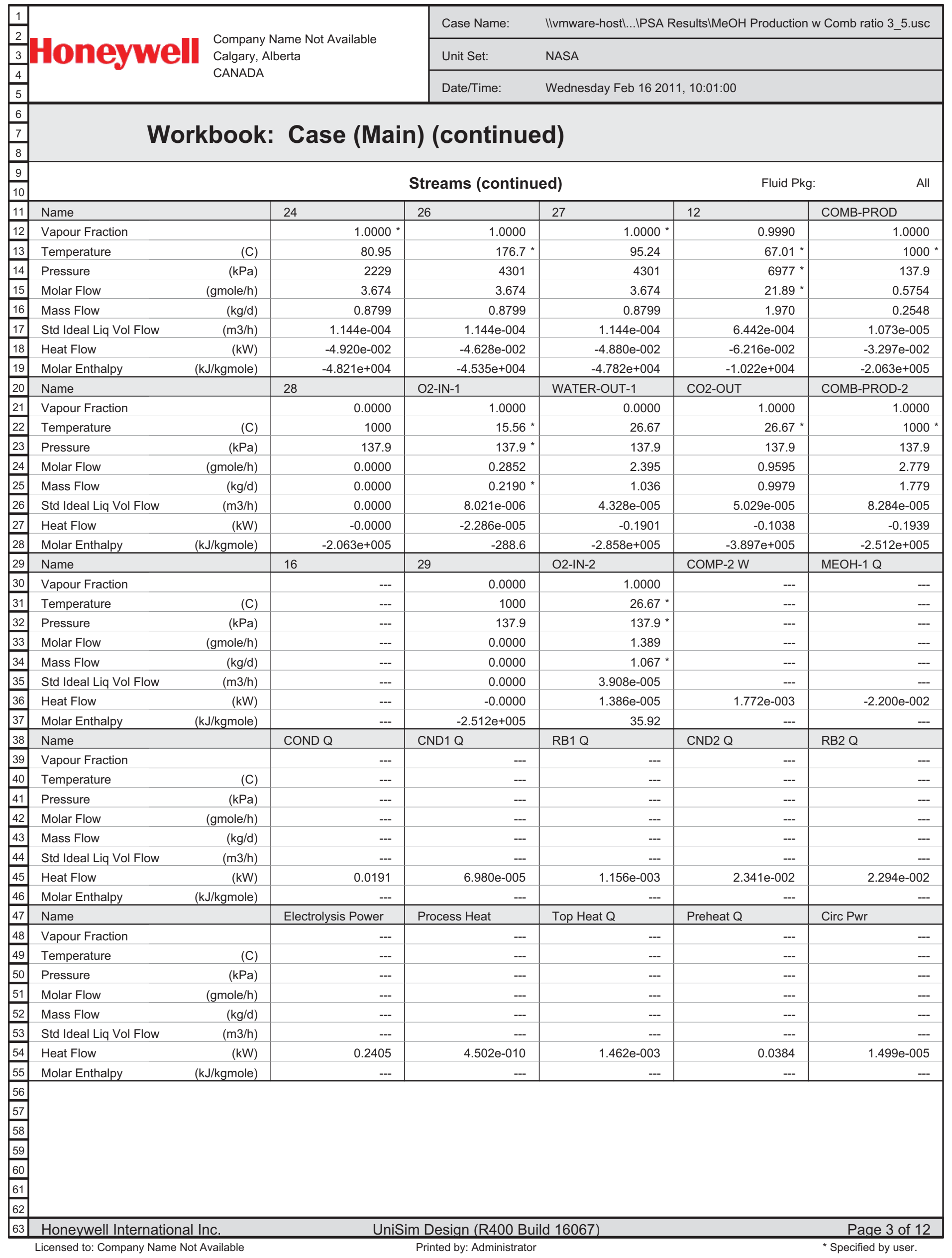




\begin{tabular}{|c|c|c|c|c|c|c|}
\hline 1 & \multirow{3}{*}{\multicolumn{2}{|c|}{$\begin{array}{l}\text { Company Name Not Available } \\
\text { Calgary, Alberta } \\
\text { CANADA }\end{array}$}} & Case Name: & \multicolumn{3}{|c|}{ IIvmware-hostl...IPSA ResultsIMeOH Production w Comb ratio 3_5.usc } \\
\hline 3 & & & Unit Set: & \multicolumn{3}{|l|}{ NASA } \\
\hline$\frac{4}{5}$ & & & Date/Time: & \multicolumn{3}{|c|}{ Wednesday Feb 16 2011, 10:01:00 } \\
\hline$\frac{6}{\frac{7}{8}}$ & \multicolumn{6}{|c|}{ Workbook: Case (Main) (continued) } \\
\hline$\frac{9}{10}$ & \multicolumn{4}{|c|}{ Streams (continued) } & \multicolumn{2}{|c|}{ Fluid Pkg: } \\
\hline 11 & Name & Amb Q & Water Pump Pwr & ST1 PWR & IC1 Q & $\mathrm{IC} 2 \mathrm{Q}$ \\
\hline 12 & Vapour Fraction & --- & 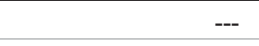 & --- & --- & --- \\
\hline 13 & Temperature & -- & --- & --- & --- & --- \\
\hline 14 & Pressure & --- & --- & --- & --- & -- \\
\hline 15 & Molar Flow & -- & --- & --- & --- & -- \\
\hline 16 & Mass Flow & -- & --- & --- & --- & -- \\
\hline 17 & Std Ideal Liq Vol Flow & --- & --- & --- & --- & --- \\
\hline 18 & Heat Flow & $-1.029 e-002$ & $1.032 \mathrm{e}-008$ & $4.520 \mathrm{e}-003$ & $3.699 \mathrm{e}-003$ & $3.423 e-003$ \\
\hline 19 & Molar Enthalpy & --- & --- & --- & -- & -- \\
\hline 20 & Name & ST2 PWR & ST3 PWR & IC3 Q & STG4 PWR & IC4 Q \\
\hline 21 & Vapour Fraction & --- & --- & --- & --- & -- \\
\hline 22 & Temperature & --- & --- & --- & --- & --- \\
\hline 23 & Pressure & --- & --- & --- & -- & -- \\
\hline 24 & Molar Flow & --- & --- & --- & -- & -- \\
\hline 25 & Mass Flow & --- & --- & --- & --- & -- \\
\hline 26 & Std Ideal Liq Vol Flow & -- & --- & -- & -- & -- \\
\hline 27 & Heat Flow & $3.695 \mathrm{e}-003$ & $3.416 \mathrm{e}-003$ & $2.930 \mathrm{e}-003$ & $2.920 \mathrm{e}-003$ & $2.518 \mathrm{e}-003$ \\
\hline 28 & Molar Enthalpy & --- & --- & --- & --- & -- \\
\hline 29 & Name & STG5 PWR & COMB-Q-1 & AMB-Q-1 & COMB-Q-2 & \\
\hline 30 & Vapour Fraction & --- & --- & --- & --- & \\
\hline 31 & Temperature & --- & --- & --- & --- & \\
\hline 32 & Pressure & --- & --- & --- & -- & \\
\hline 33 & Molar Flow & --- & --- & --- & -- & \\
\hline 34 & Mass Flow & --- & --- & --- & --- & \\
\hline 35 & Std Ideal Liq Vol Flow & --- & --- & -- & -- & \\
\hline 36 & Heat Flow & $2.555 \mathrm{e}-003$ & $-3.227 e-002$ & $-6.712 e-002$ & -0.1325 & \\
\hline 37 & Molar Enthalpy & -- & --- & --- & --- & \\
\hline \begin{tabular}{|l}
38 \\
39 \\
\end{tabular} & \multicolumn{4}{|c|}{ Composition } & \multicolumn{2}{|c|}{ Fluid Pkg: } \\
\hline 40 & Name & SYNG-2 & M-RECY2 & 1 & SYNG-3 & SYNG-5 \\
\hline 41 & Master Comp Mole Frac (H2O) & 0.0260 & 0.0003 & 0.0046 & 0.0046 & 0.0046 \\
\hline 42 & Master Comp Mole Frac (Oxygen) & 0.0000 & 0.0000 & 0.0000 & 0.0000 & 0.0000 \\
\hline 43 & Master Comp Mole Frac (Hydrogen) & 0.7163 & 0.9859 & 0.9407 & 0.9407 & 0.9407 \\
\hline 44 & Master Comp Mole Frac (CO) & 0.2047 & 0.0027 & 0.0366 & 0.0366 & 0.0366 \\
\hline 45 & Master Comp Mole Frac (CO2) & 0.0530 & 0.0056 & 0.0135 & 0.0135 & 0.0135 \\
\hline 46 & Master Comp Mole Frac (Methanol) & 0.0000 & 0.0053 & 0.0044 & 0.0044 & 0.0044 \\
\hline 47 & Master Comp Mole Frac (diM-Ether) & 0.0000 & 0.0002 & 0.0001 & 0.0001 & 0.0001 \\
\hline 48 & Master Comp Mole Frac (1-Propanol) & 0.0000 & 0.0000 & 0.0000 & 0.0000 & 0.0000 \\
\hline 49 & Name & $\mathrm{MEOH}-2$ & $\mathrm{MEOH}-4$ & Vap Out & 2 & 3 \\
\hline 50 & Master Comp Mole Frac (H2O) & 0.0146 & 0.0146 & 0.0145 & 0.0145 & 0.0146 \\
\hline 51 & Master Comp Mole Frac (Oxygen) & 0.0000 & 0.0000 & 0.0000 & 0.0000 & 0.0000 \\
\hline 52 & Master Comp Mole Frac (Hydrogen) & 0.9256 & 0.9256 & 0.9256 & 0.9256 & 0.9256 \\
\hline 53 & Master Comp Mole Frac (CO) & 0.0026 & 0.0026 & 0.0026 & 0.0026 & 0.0026 \\
\hline 54 & Master Comp Mole Frac (CO2) & 0.0053 & 0.0053 & 0.0053 & 0.0053 & 0.0053 \\
\hline 55 & Master Comp Mole Frac (Methanol) & 0.0518 & 0.0518 & 0.0518 & 0.0518 & 0.0518 \\
\hline 56 & Master Comp Mole Frac (diM-Ether) & 0.0002 & 0.0002 & 0.0002 & 0.0002 & 0.0002 \\
\hline 57 & Master Comp Mole Frac (1-Propanol) & 0.0000 & 0.0000 & 0.0000 & 0.0000 & 0.0000 \\
\hline \begin{tabular}{|l|}
58 \\
59 \\
60 \\
61 \\
62 \\
\end{tabular} & & & & & & \\
\hline 63 & Honeywell International Inc. & Unis & $\mathrm{n}$ Design (R400 Bu & (d 16067) & & Page 4 of 12 \\
\hline
\end{tabular}




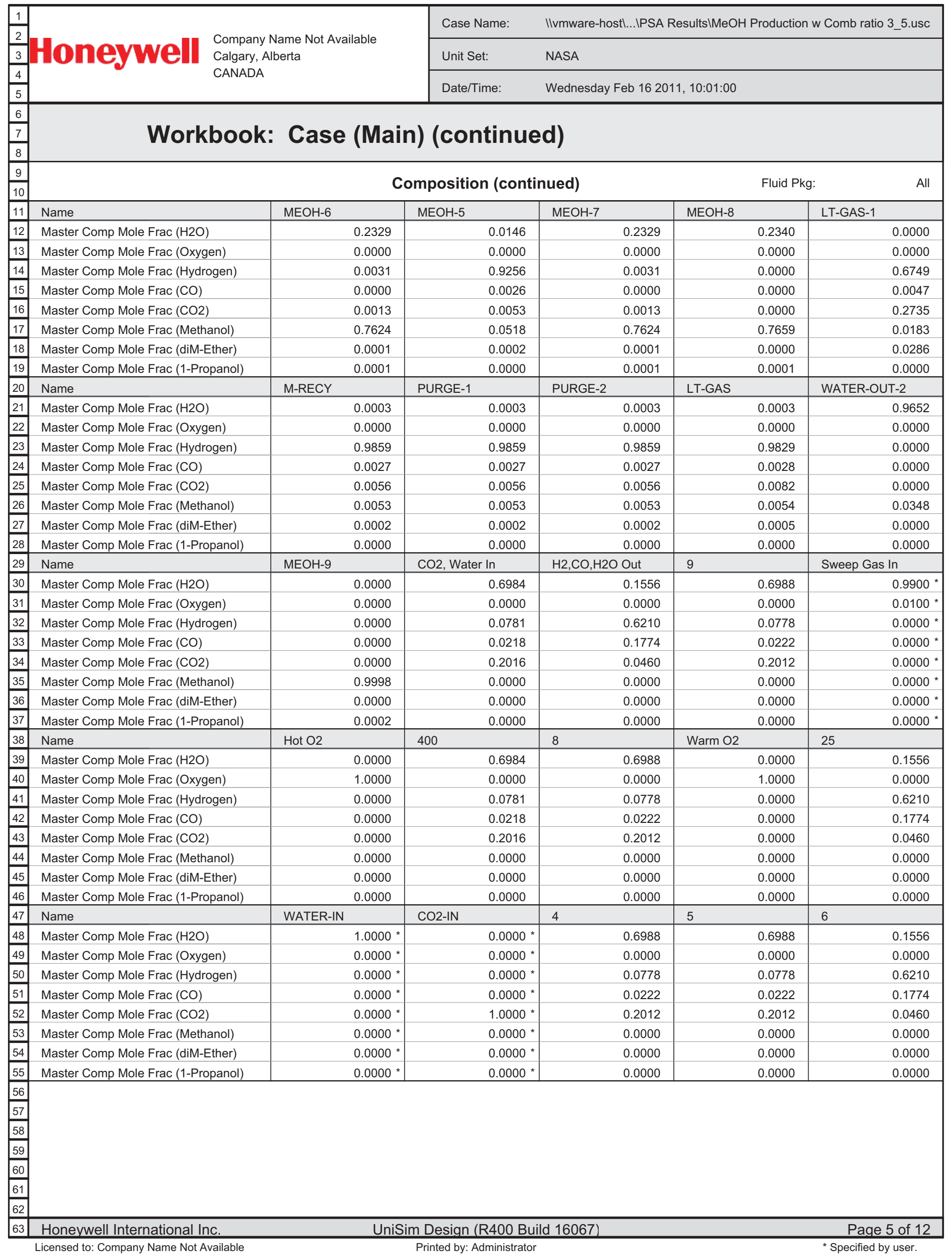




\begin{tabular}{|c|c|c|c|c|c|c|}
\hline 1 & & & Case Name: & IIvmware-hostl...IPSA & esults $\mid \mathrm{MeOH}$ Production & w Comb ratio 3_5.usc \\
\hline 3 & DOCNWE Calgar & perta & Unit Set: & NASA & & \\
\hline$\frac{7}{5}$ & URIVI & & Date/Time: & Wednesday Feb 1620 & 1, 10:01:00 & \\
\hline$\frac{6}{\frac{7}{8}}$ & Workboo & Case (Ma & ) (continue & d) & & \\
\hline$\frac{9}{10}$ & & & mposition (contir & hued) & Fluid Pkg & All \\
\hline 11 & Name & 7 & 10 & SYNG-1 & 13 & 14 \\
\hline 12 & Master Comp Mole Frac $(\mathrm{H} 2 \mathrm{O})$ & 0.1556 & 0.1556 & 0.0260 & 0.9999 & 0.9999 \\
\hline 13 & Master Comp Mole Frac (Oxygen) & 0.0000 & 0.0000 & 0.0000 & 0.0000 & 0.0000 \\
\hline 14 & Master Comp Mole Frac (Hydrogen) & 0.6210 & 0.6210 & 0.7163 & 0.0001 & 0.0001 \\
\hline 15 & Master Comp Mole Frac (CO) & 0.1774 & 0.1774 & 0.2047 & 0.0000 & 0.0000 \\
\hline 16 & Master Comp Mole Frac (CO2) & 0.0460 & 0.0460 & 0.0530 & 0.0000 & 0.0000 \\
\hline 17 & Master Comp Mole Frac (Methanol) & 0.0000 & 0.0000 & 0.0000 & 0.0000 & 0.0000 \\
\hline 18 & Master Comp Mole Frac (diM-Ether) & 0.0000 & 0.0000 & 0.0000 & 0.0000 & 0.0000 \\
\hline 19 & Master Comp Mole Frac (1-Propanol) & 0.0000 & 0.0000 & 0.0000 & 0.0000 & 0.0000 \\
\hline 20 & Name & SYNG-RCY & O2-OUT & 18 & 17 & 11 \\
\hline 21 & Master Comp Mole Frac $(\mathrm{H} 2 \mathrm{O})$ & 0.5624 & 0.0000 & 0.6988 & 0.6988 * & 0.1556 \\
\hline 22 & Master Comp Mole Frac (Oxygen) & 0.0000 & 1.0000 & 0.0000 & $0.0000 *$ & 0.0000 \\
\hline 23 & Master Comp Mole Frac (Hydrogen) & 0.3218 & 0.0000 & 0.0778 & $0.0778 *$ & 0.6210 \\
\hline 24 & Master Comp Mole Frac (CO) & 0.0919 & 0.0000 & 0.0222 & 0.0222 * & 0.1774 \\
\hline 25 & Master Comp Mole Frac (CO2) & 0.0238 & 0.0000 & 0.2012 & 0.2012 * & 0.0460 \\
\hline 26 & Master Comp Mole Frac (Methanol) & 0.0000 & 0.0000 & 0.0000 & $0.0000 *$ & 0.0000 \\
\hline 27 & Master Comp Mole Frac (diM-Ether) & 0.0000 & 0.0000 & 0.0000 & $0.0000 *$ & 0.0000 \\
\hline 28 & Master Comp Mole Frac (1-Propanol) & 0.0000 & 0.0000 & 0.0000 & $0.0000 *$ & 0.0000 \\
\hline 29 & Name & 19 & 20 & 21 & 22 & 23 \\
\hline 30 & Master Comp Mole Frac (H2O) & 0.0260 & 0.0260 & 0.0260 & 0.0260 & 0.0260 \\
\hline 31 & Master Comp Mole Frac (Oxygen) & 0.0000 & 0.0000 & 0.0000 & 0.0000 & 0.0000 \\
\hline 32 & Master Comp Mole Frac (Hydrogen) & 0.7163 & 0.7163 & 0.7163 & 0.7163 & 0.7163 \\
\hline 33 & Master Comp Mole Frac (CO) & 0.2047 & 0.2047 & 0.2047 & 0.2047 & 0.2047 \\
\hline 34 & Master Comp Mole Frac (CO2) & 0.0530 & 0.0530 & 0.0530 & 0.0530 & 0.0530 \\
\hline 35 & Master Comp Mole Frac (Methanol) & 0.0000 & 0.0000 & 0.0000 & 0.0000 & 0.0000 \\
\hline 36 & Master Comp Mole Frac (diM-Ether) & 0.0000 & 0.0000 & 0.0000 & 0.0000 & 0.0000 \\
\hline 37 & Master Comp Mole Frac (1-Propanol) & 0.0000 & 0.0000 & 0.0000 & 0.0000 & 0.0000 \\
\hline 38 & Name & 24 & 26 & 27 & 12 & COMB-PROD \\
\hline 39 & Master Comp Mole Frac $(\mathrm{H} 2 \mathrm{O})$ & 0.0260 & 0.0260 & 0.0260 & $0.0046 *$ & 0.9832 \\
\hline 40 & Master Comp Mole Frac (Oxygen) & 0.0000 & 0.0000 & 0.0000 & $0.0000 *$ & 0.0001 \\
\hline 41 & Master Comp Mole Frac (Hydrogen) & 0.7163 & 0.7163 & 0.7163 & $0.9407 *$ & 0.0000 \\
\hline 42 & Master Comp Mole Frac (CO) & 0.2047 & 0.2047 & 0.2047 & $0.0366 *$ & 0.0000 \\
\hline 43 & Master Comp Mole Frac (CO2) & 0.0530 & 0.0530 & 0.0530 & $0.0135 *$ & 0.0162 \\
\hline 44 & Master Comp Mole Frac (Methanol) & 0.0000 & 0.0000 & 0.0000 & $0.0044 *$ & 0.0000 \\
\hline 45 & Master Comp Mole Frac (diM-Ether) & 0.0000 & 0.0000 & 0.0000 & $0.0001 *$ & 0.0004 \\
\hline 46 & Master Comp Mole Frac (1-Propanol) & 0.0000 & 0.0000 & 0.0000 & $0.0000 *$ & 0.0000 \\
\hline 47 & Name & 28 & $\mathrm{O} 2-\mathrm{IN}-1$ & WATER-OUT-1 & CO2-OUT & COMB-PROD-2 \\
\hline 48 & Master Comp Mole Frac (H2O) & 0.9832 & $0.0000 *$ & 0.9994 & 0.0259 & 0.6666 \\
\hline 49 & Master Comp Mole Frac (Oxygen) & 0.0001 & $1.0000 *$ & 0.0000 & 0.0003 & 0.0001 \\
\hline 50 & Master Comp Mole Frac (Hydrogen) & 0.0000 & $0.0000 *$ & 0.0000 & 0.0000 & 0.0000 \\
\hline 51 & Master Comp Mole Frac (CO) & 0.0000 & $0.0000 *$ & 0.0000 & 0.0000 & 0.0000 \\
\hline 52 & Master Comp Mole Frac (CO2) & 0.0162 & $0.0000 *$ & 0.0006 & 0.9733 & 0.3333 \\
\hline 53 & Master Comp Mole Frac (Methanol) & 0.0000 & $0.0000 *$ & 0.0000 & 0.0000 & 0.0000 \\
\hline 54 & Master Comp Mole Frac (diM-Ether) & 0.0004 & $0.0000 *$ & 0.0000 & 0.0003 & 0.0000 \\
\hline 55 & Master Comp Mole Frac (1-Propanol) & 0.0000 & $0.0000 *$ & 0.0000 & 0.0002 & 0.0001 \\
\hline \begin{tabular}{|l|}
56 \\
57 \\
58 \\
59 \\
60 \\
61 \\
62 \\
\end{tabular} & & & & & & \\
\hline 63 & Honeywell International Inc. & Uni & n Design (R400 Buil & Id 16067) & & Page 6 of 12 \\
\hline
\end{tabular}




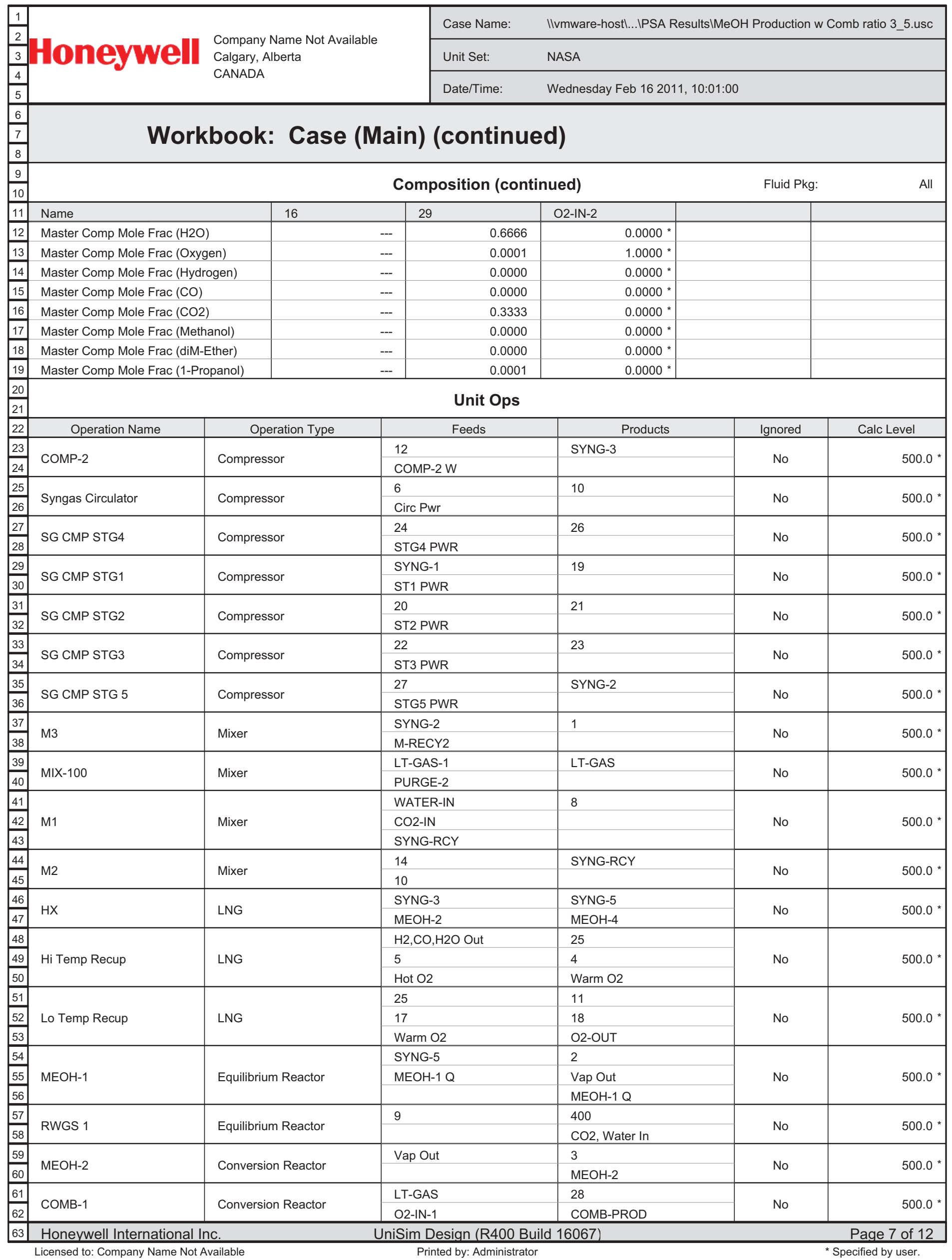




\begin{tabular}{|c|c|c|c|c|c|c|}
\hline$\frac{1}{2}$ & & \multirow{3}{*}{$\begin{array}{l}\text { Company Name Not Available } \\
\text { Calgary, Alberta } \\
\text { CANADA }\end{array}$} & Case Name: & \\
\hline 3 & & & Unit Set: & \multicolumn{3}{|c|}{$\begin{array}{l}\text { Ilvmware-hostl...IPSA ResultsIMeOH Production w Comb ratio 3_5.usc } \\
\text { NASA }\end{array}$} \\
\hline$\frac{4}{5}$ & & & Date/Time: & \multicolumn{3}{|c|}{ Wednesday Feb 16 2011, 10:01:00 } \\
\hline \begin{tabular}{l|}
6 \\
8 \\
\end{tabular} & \multicolumn{6}{|c|}{ Workbook: Case (Main) (continued) } \\
\hline$\frac{9}{10}$ & \multicolumn{6}{|c|}{ Unit Ops (continued) } \\
\hline 11 & Operation Name & Operation Type & Feeds & Products & Ignored & Calc Level \\
\hline 12 & COMB-1 & Conversion Reactor & COMB-Q-1 & COMB-Q-1 & No & 500.0 * \\
\hline 13 & \multirow{3}{*}{ COMB-2 } & \multirow{3}{*}{ Conversion Reactor } & MEOH-9 & 29 & \multirow{3}{*}{ No } & \multirow{3}{*}{500.0 * } \\
\hline 14 & & & O2-IN-2 & COMB-PROD-2 & & \\
\hline 15 & & & COMB-Q-2 & COMB-Q-2 & & \\
\hline 16 & \multirow{2}{*}{ KO-DRM } & \multirow{2}{*}{ Separator } & MEOH-5 & MEOH-6 & \multirow{2}{*}{ No } & \multirow{2}{*}{$500.0 *$} \\
\hline 17 & & & & M-RECY & & \\
\hline 18 & & & 7 & 13 & & \\
\hline 19 & Water Knockout Tank & Separator & $A m b Q$ & SYNG-1 & No & 500.0 * \\
\hline 20 & & & & Amb Q & & \\
\hline 21 & & & COMB-PROD & WATER-OUT-1 & & \\
\hline 22 & KO-DRM 2 & Separator & COMB-PROD-2 & CO2-OUT & No & 500.0 * \\
\hline 23 & & & AMB-Q-1 & AMB-Q-1 & & \\
\hline 24 & CONDNSR & Cooler & MEOH-4 & MEOH-5 & $\mathrm{No}$ & 5000 * $>2>0$ \\
\hline 25 & CUIVDTSOR & COolei & & COND Q & No & 500.0 \\
\hline 26 & INT CI R 1 & Conler & 19 & 20 & $\mathrm{No}$ & 5000 * $>2>>0$ \\
\hline 27 & IVI CLR I & Cooler & & IC1 Q & NO & 500.0 \\
\hline 28 & INT CIR 2 & Cooler & 21 & 22 & $\mathrm{No}$ & 5000 * $>2>0$ \\
\hline 29 & IVI CLR 2 & COOle! & & $\mathrm{IC} 2 \mathrm{Q}$ & No & 500.0 \\
\hline 30 & INT CIP 3 & Conler & 23 & 24 & $\mathrm{No}$ & 5000 * \\
\hline 31 & IVI CLR o & Couler & & IC3 Q & No & 500.0 \\
\hline 32 & INT CIR 4 & Cooler & 26 & 27 & $\mathrm{No}$ & 5000 * $>2>0$ \\
\hline 33 & IIVI CLR 4 & COolei & & IC4 Q & No & 500.0 \\
\hline 34 & VALVE-3 & Valve & MEOH-6 & MEOH-7 & No & $500.0 *$ \\
\hline 35 & VALVE-2 & Valve & PURGE-1 & PURGE-2 & No & 500.0 * \\
\hline 36 & & & MEOH-7 & MEOH-8 & & \\
\hline 37 & $\mathrm{~T}-100$ & Distillation & RB1 Q & LT-GAS-1 & No & 2500 * \\
\hline 38 & & & & CND1 Q & & \\
\hline 39 & & & MEOH-8 & WATER-OUT-2 & & \\
\hline 40 & $\mathrm{~T}-101$ & Distillation & RB2 Q & MEOH-9 & No & 2500 * \\
\hline 41 & & & & CND2 Q & & \\
\hline 42 & RCY -4 & Recycle & 8 & 17 & No & 3500 * \\
\hline 43 & $\mathrm{RCY}-1$ & Recycle & 1 & 12 & No & 3500 * \\
\hline 44 & TFF-100 & Tee & M-RECY & M-RECY2 & $\mathrm{No}$ & 5000 * $>2 \div$ \\
\hline 45 & TEE-IOU & ree & & PURGE-1 & No & 500.0 \\
\hline 46 & $T 1$ & Tee & 11 & 6 & $\mathrm{No}$ & 5000 * $>2>$; \\
\hline 47 & 11 & ree & & 7 & No & 500.0 \\
\hline 48 & & & Sweep Gas In & Hot O2 & & \\
\hline 49 & Hiah Tomnerature Co-Flectrol & Standard Sub-Flowsheet & $\mathrm{CO} 2$, Water In & $\mathrm{H} 2, \mathrm{CO}, \mathrm{H} 2 \mathrm{O}$ Out & No & $2500 *$ \\
\hline 50 & HIgn Iemperature Co-Electrol & Standara Sub-Flowsneet & Process Heat & & No & 2500 \\
\hline 51 & & & Electrolysis Power & & & \\
\hline 52 & Tonning Heat & Heater & 4 & 9 & $\mathrm{No}$ & 5000 * $>2>$; \\
\hline 53 & Iopping neal & Meater & Top Heat Q & & NO & 500.0 \\
\hline 54 & Preheater & Heater & 18 & 5 & $\mathrm{No}$ & 5000 * $>2>>0$ \\
\hline 55 & Preneater & neater & Preheat Q & & NO & 500.0 \\
\hline 56 & SPRDSHT-1 & Spreadsheet & & & No & $500.0 *$ \\
\hline 57 & Water Pumn & Pumn & 13 & 14 & No & $5000 *$ \\
\hline 58 & Water Pump & Pump & Water Pump Pwr & & No & 500.0 \\
\hline 59 & & & & & & \\
\hline 60 & & & & & & \\
\hline$\frac{61}{62}$ & & & & & & \\
\hline 63 & Honeywell International In & c. & niSim Design (R400 & ild 16067) & & Page 8 of 12 \\
\hline
\end{tabular}




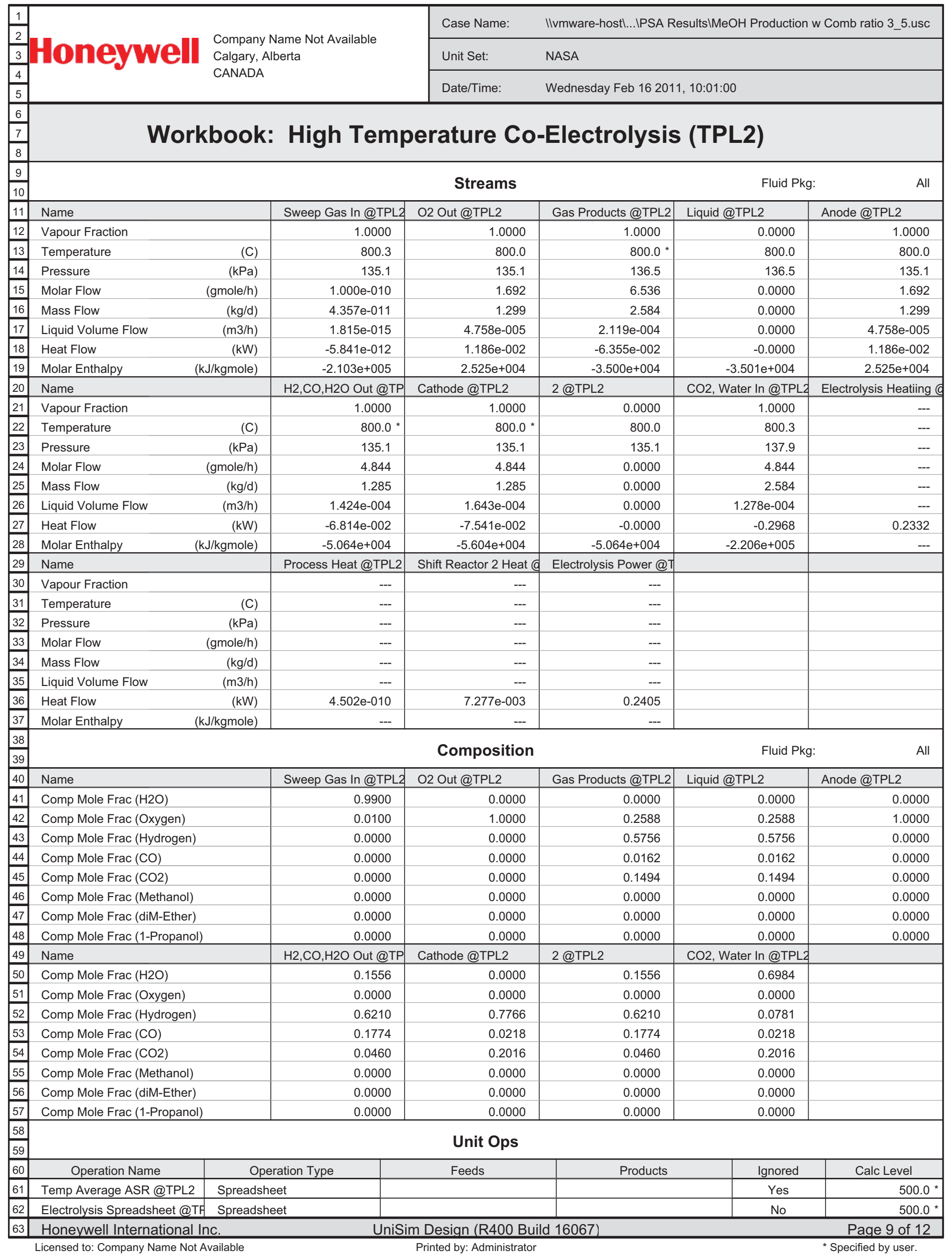




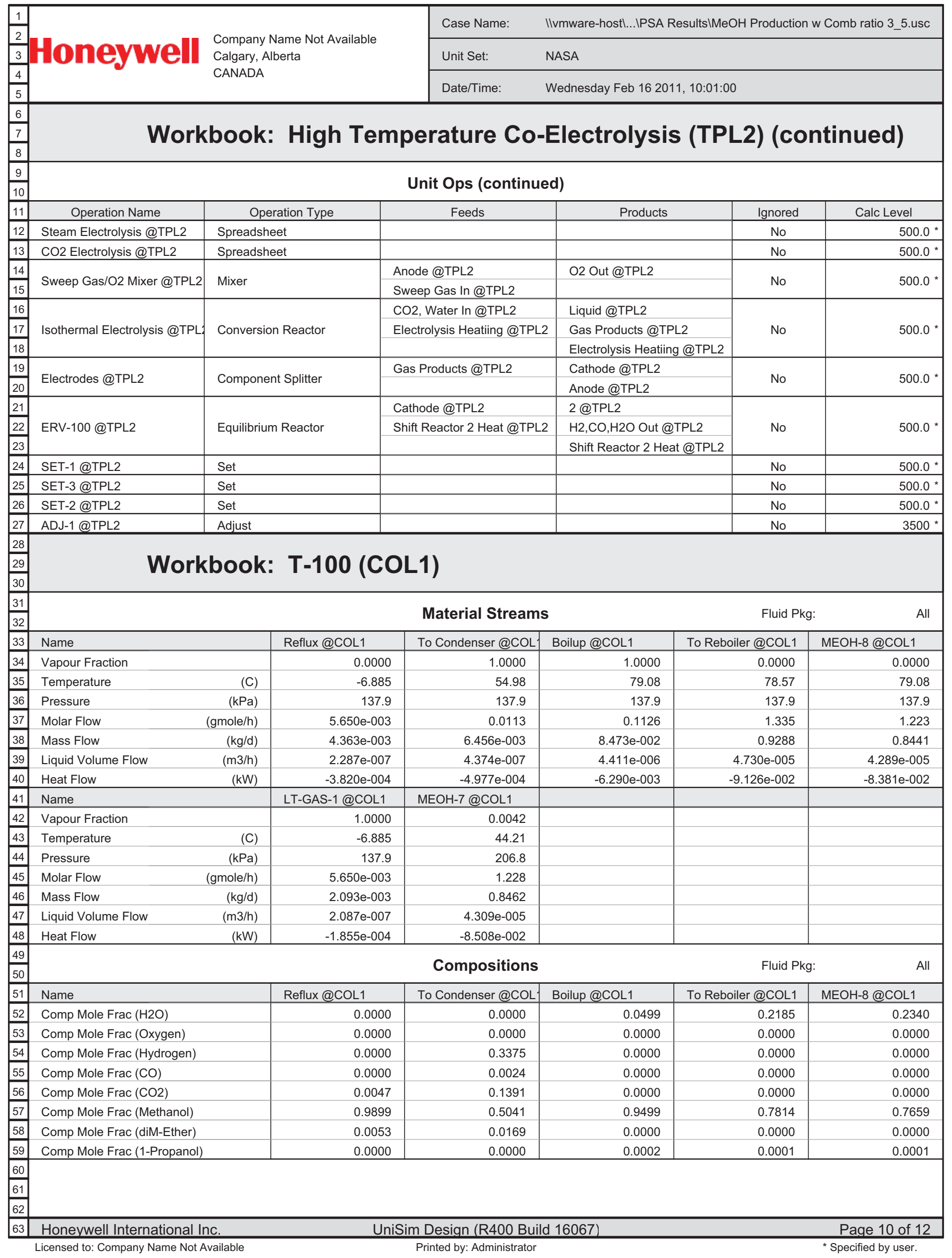




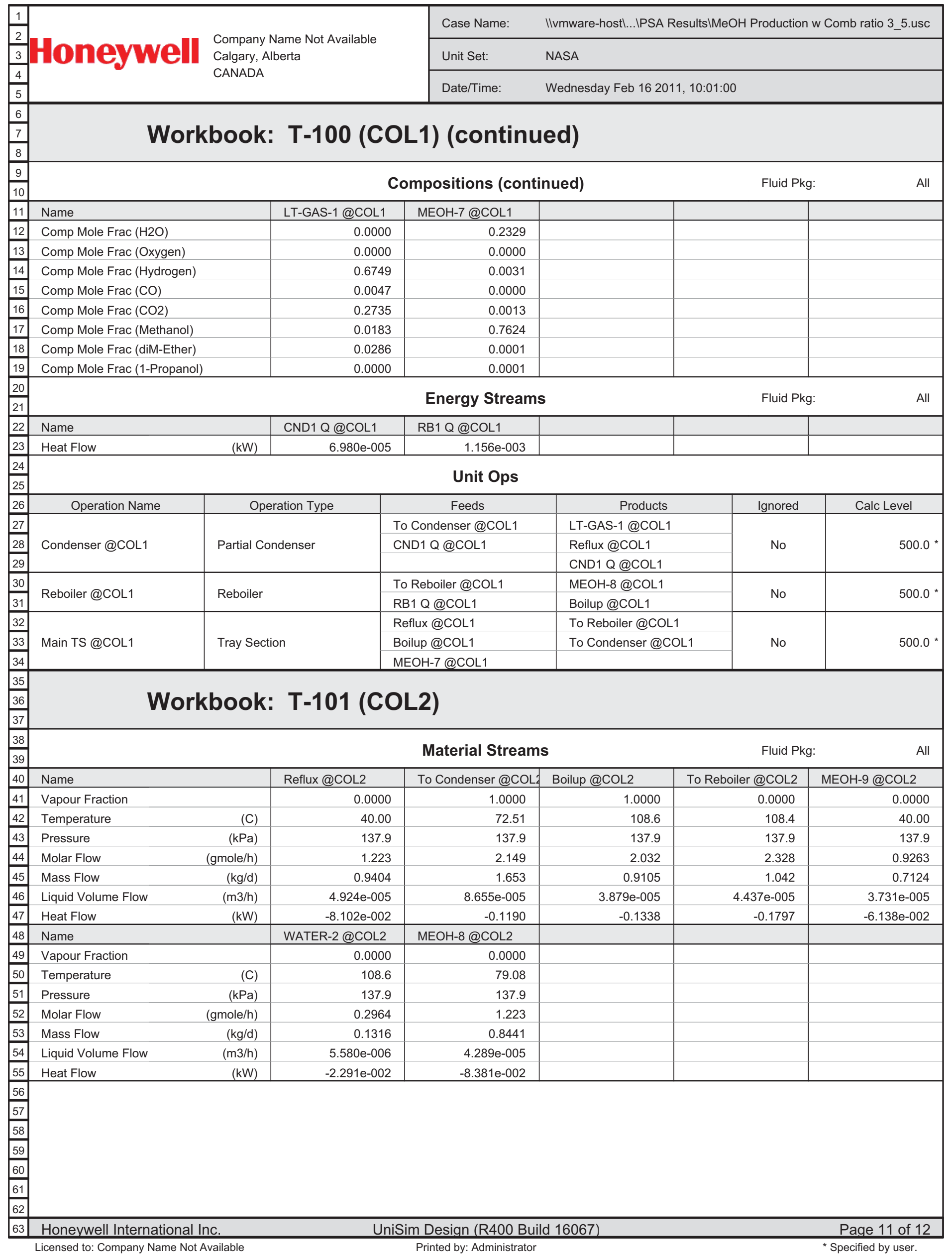




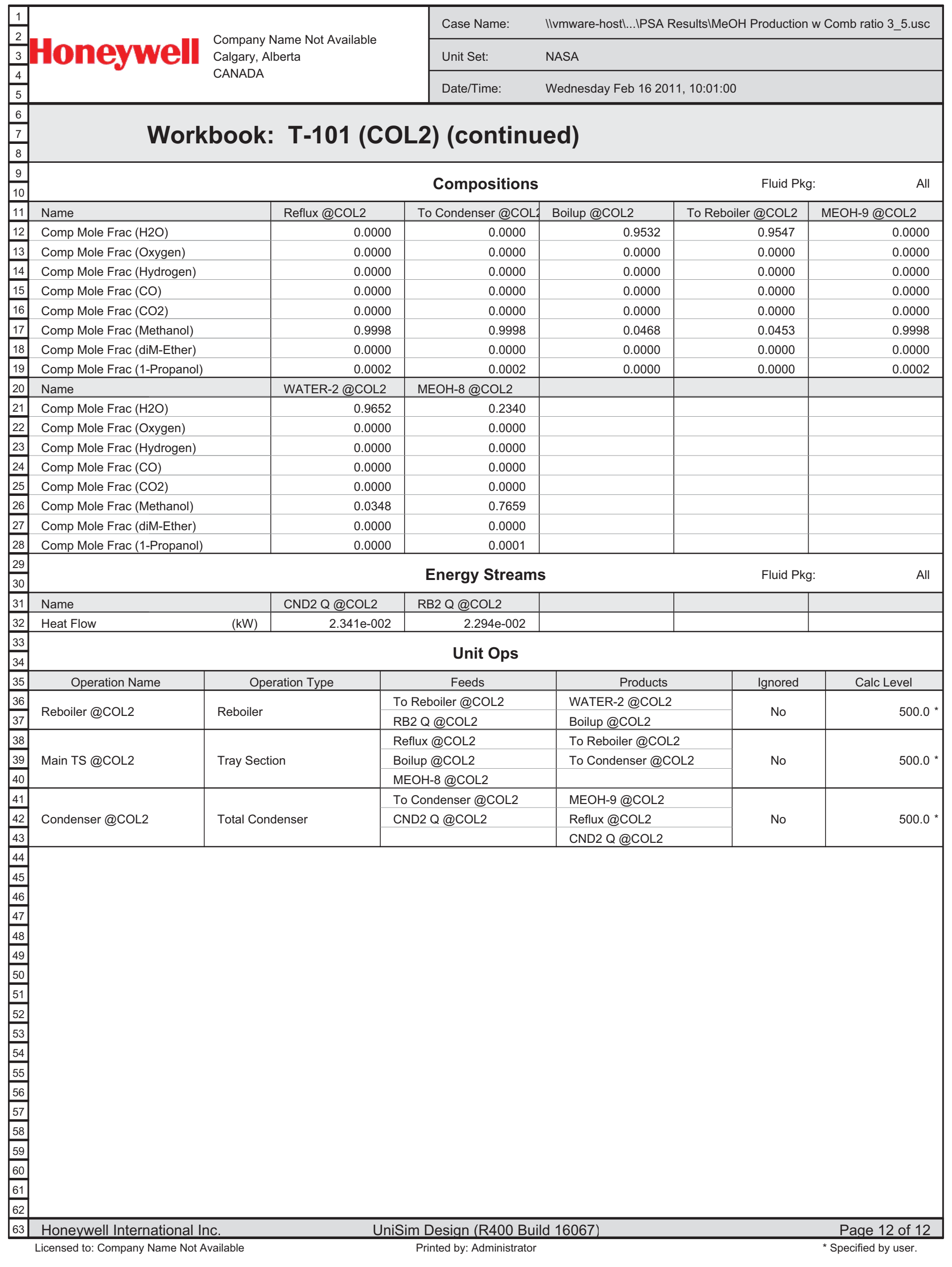




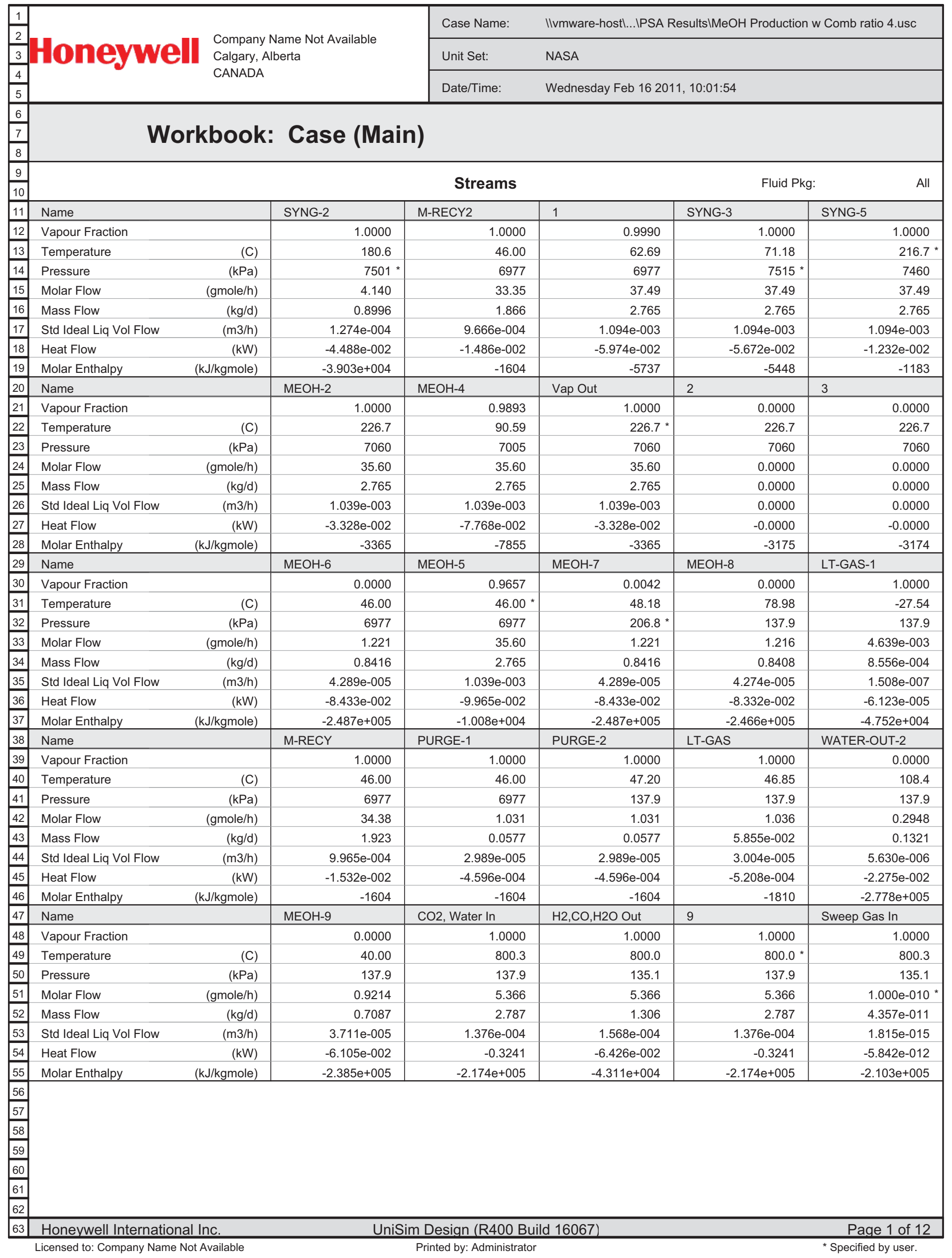




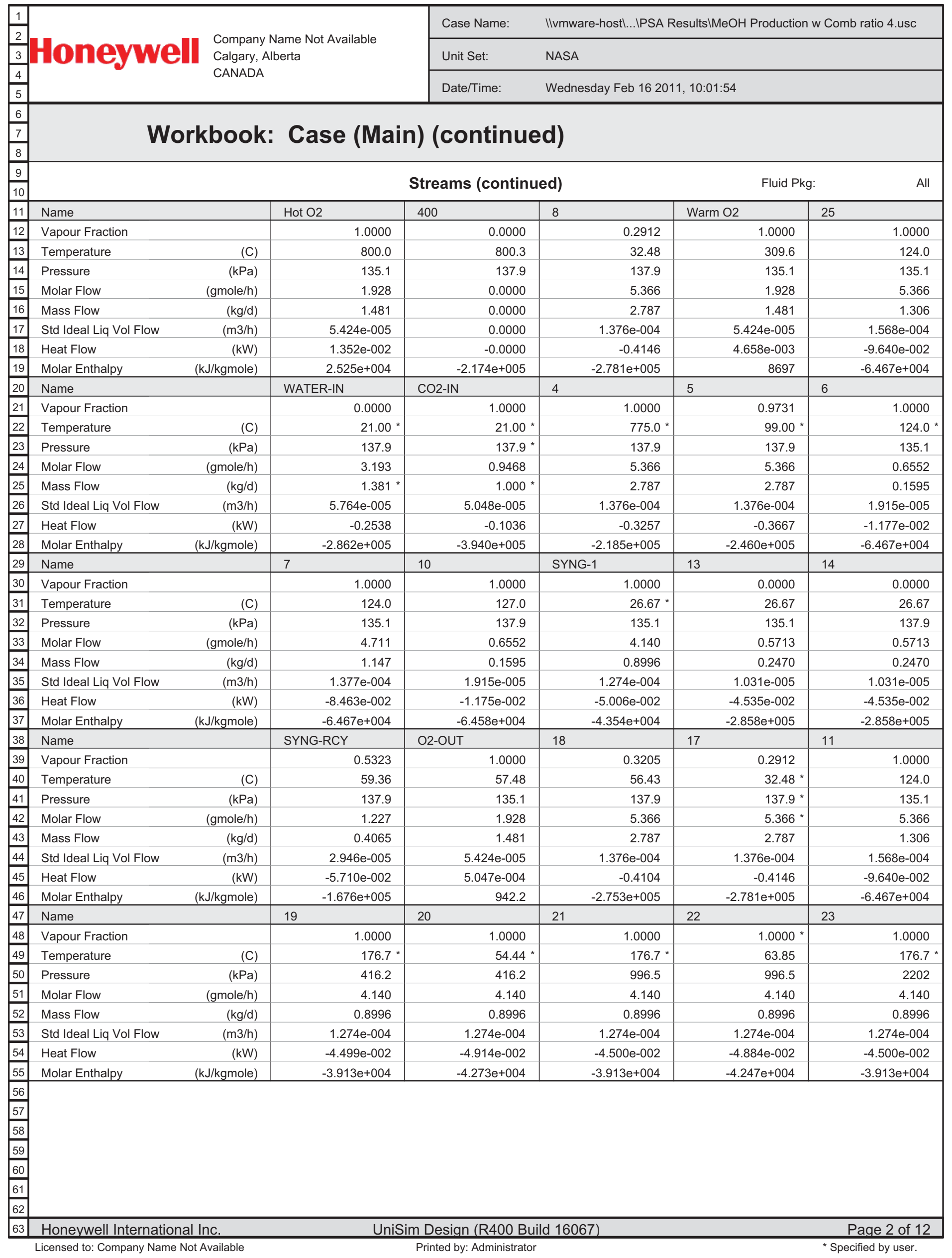




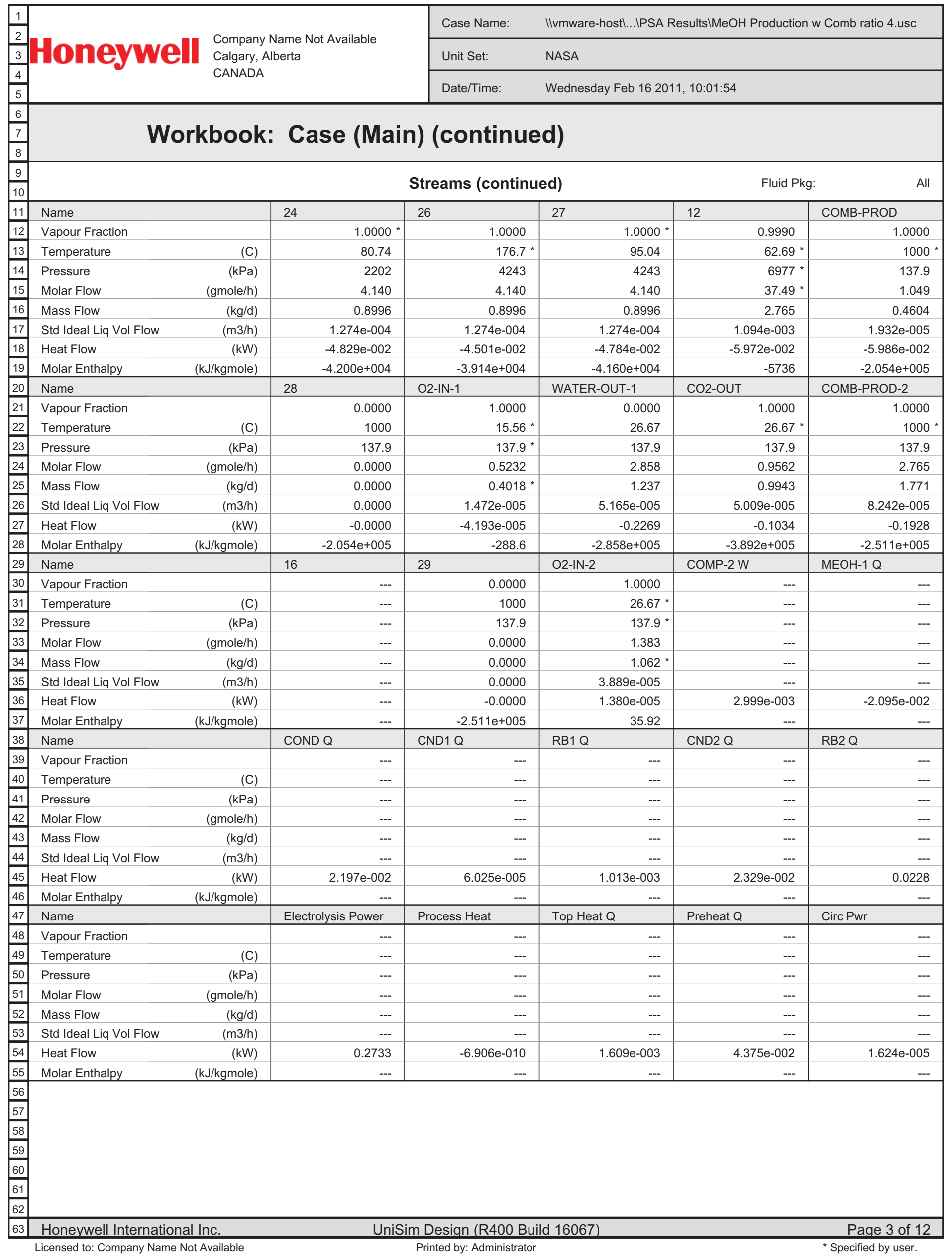




\begin{tabular}{|c|c|c|c|c|c|c|}
\hline 1 & \multirow{3}{*}{\multicolumn{2}{|c|}{$\begin{array}{l}\text { Company Name Not Available } \\
\text { Calgary, Alberta } \\
\text { CANADA }\end{array}$}} & \multirow{2}{*}{$\begin{array}{l}\text { Case Name: } \\
\text { Unit Set: }\end{array}$} & \multicolumn{3}{|c|}{ |lvmware-hostl...IPSA ResultsIMeOH Production w Comb ratio 4.usc } \\
\hline 3 & & & & \multicolumn{3}{|l|}{ NASA } \\
\hline$\frac{4}{5}$ & & & Date/Time: & \multicolumn{3}{|c|}{ Wednesday Feb 16 2011, 10:01:54 } \\
\hline$\frac{6}{\frac{7}{8}}$ & \multicolumn{6}{|c|}{ Workbook: Case (Main) (continued) } \\
\hline$\frac{9}{10}$ & \multicolumn{4}{|c|}{ Streams (continued) } & \multicolumn{2}{|c|}{ Fluid Pkg: } \\
\hline 11 & Name & Amb Q & Water Pump Pwr & ST1 PWR & IC1 Q & $\mathrm{IC} 2 \mathrm{Q}$ \\
\hline 12 & Vapour Fraction & --- & 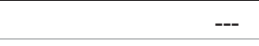 & --- & --- & --- \\
\hline 13 & Temperature & --- & --- & --- & --- & --- \\
\hline 14 & Pressure & --- & --- & --- & --- & -- \\
\hline 15 & Molar Flow & -- & --- & --- & --- & -- \\
\hline 16 & Mass Flow & -- & --- & --- & --- & -- \\
\hline 17 & Std Ideal Liq Vol Flow & --- & --- & --- & --- & --- \\
\hline 18 & Heat Flow & $-1.078 e-002$ & $1.045 \mathrm{e}-008$ & $5.069 \mathrm{e}-003$ & $4.147 \mathrm{e}-003$ & $3.843 e-003$ \\
\hline 19 & Molar Enthalpy & --- & --- & --- & --- & -- \\
\hline 20 & Name & ST2 PWR & ST3 PWR & IC3 Q & STG4 PWR & IC4 Q \\
\hline 21 & Vapour Fraction & --- & --- & --- & --- & -- \\
\hline 22 & Temperature & --- & --- & --- & --- & --- \\
\hline 23 & Pressure & --- & --- & --- & --- & -- \\
\hline 24 & Molar Flow & --- & --- & --- & --- & -- \\
\hline 25 & Mass Flow & --- & --- & --- & --- & -- \\
\hline 26 & Std Ideal Liq Vol Flow & --- & --- & --- & --- & -- \\
\hline 27 & Heat Flow & $4.144 \mathrm{e}-003$ & $3.837 \mathrm{e}-003$ & $3.290 \mathrm{e}-003$ & $3.282 \mathrm{e}-003$ & $2.826 \mathrm{e}-003$ \\
\hline 28 & Molar Enthalpy & --- & --- & --- & --- & -- \\
\hline 29 & Name & STG5 PWR & COMB-Q-1 & AMB-Q-1 & COMB-Q-2 & \\
\hline 30 & Vapour Fraction & -- & --- & --- & --- & \\
\hline 31 & Temperature & --- & --- & --- & --- & \\
\hline 32 & Pressure & --- & --- & --- & --- & \\
\hline 33 & Molar Flow & -- & --- & --- & --- & \\
\hline 34 & Mass Flow & --- & --- & --- & --- & \\
\hline 35 & Std Ideal Liq Vol Flow & --- & --- & -- & --- & \\
\hline 36 & Heat Flow & $2.956 \mathrm{e}-003$ & $-5.930 e-002$ & $-7.759 \mathrm{e}-002$ & -0.1318 & \\
\hline 37 & Molar Enthalpy & --- & --- & --- & --- & \\
\hline 38 & \multicolumn{4}{|c|}{ Composition } & \multicolumn{2}{|c|}{ Fluid Pkg: } \\
\hline 40 & Name & SYNG-2 & M-RECY2 & 1 & SYNG-3 & SYNG-5 \\
\hline 41 & Master Comp Mole Frac (H2O) & 0.0260 & 0.0003 & 0.0032 & 0.0032 & 0.0032 \\
\hline 42 & Master Comp Mole Frac (Oxygen) & 0.0000 & 0.0000 & 0.0000 & 0.0000 & 0.0000 \\
\hline 43 & Master Comp Mole Frac (Hydrogen) & 0.7453 & 0.9899 & 0.9629 & 0.9629 & 0.9629 \\
\hline 44 & Master Comp Mole Frac (CO) & 0.1863 & 0.0016 & 0.0220 & 0.0220 & 0.0220 \\
\hline 45 & Master Comp Mole Frac (CO2) & 0.0424 & 0.0017 & 0.0062 & 0.0062 & 0.0062 \\
\hline 46 & Master Comp Mole Frac (Methanol) & 0.0000 & 0.0063 & 0.0056 & 0.0056 & 0.0056 \\
\hline 47 & Master Comp Mole Frac (diM-Ether) & 0.0000 & 0.0001 & 0.0001 & 0.0001 & 0.0001 \\
\hline 48 & Master Comp Mole Frac (1-Propanol) & 0.0000 & 0.0000 & 0.0000 & 0.0000 & 0.0000 \\
\hline 49 & Name & MEOH-2 & $\mathrm{MEOH}-4$ & Vap Out & 2 & 3 \\
\hline 50 & Master Comp Mole Frac (H2O) & 0.0082 & 0.0082 & 0.0082 & 0.0074 & 0.0074 \\
\hline 51 & Master Comp Mole Frac (Oxygen) & 0.0000 & 0.0000 & 0.0000 & 0.0000 & 0.0000 \\
\hline 52 & Master Comp Mole Frac (Hydrogen) & 0.9561 & 0.9561 & 0.9561 & 0.9568 & 0.9569 \\
\hline 53 & Master Comp Mole Frac (CO) & 0.0015 & 0.0015 & 0.0015 & 0.0015 & 0.0015 \\
\hline 54 & Master Comp Mole Frac (CO2) & 0.0017 & 0.0017 & 0.0017 & 0.0017 & 0.0017 \\
\hline 55 & Master Comp Mole Frac (Methanol) & 0.0323 & 0.0323 & 0.0324 & 0.0324 & 0.0324 \\
\hline 56 & Master Comp Mole Frac (diM-Ether) & 0.0001 & 0.0001 & 0.0001 & 0.0001 & 0.0001 \\
\hline 57 & Master Comp Mole Frac (1-Propanol) & 0.0000 & 0.0000 & 0.0000 & 0.0000 & 0.0000 \\
\hline \begin{tabular}{|l|}
58 \\
59 \\
60 \\
61 \\
62 \\
\end{tabular} & & & & & & \\
\hline 63 & Honeywell International Inc. & Unis & n Design (R400 Bu & (d 16067) & & Page 4 of 12 \\
\hline
\end{tabular}




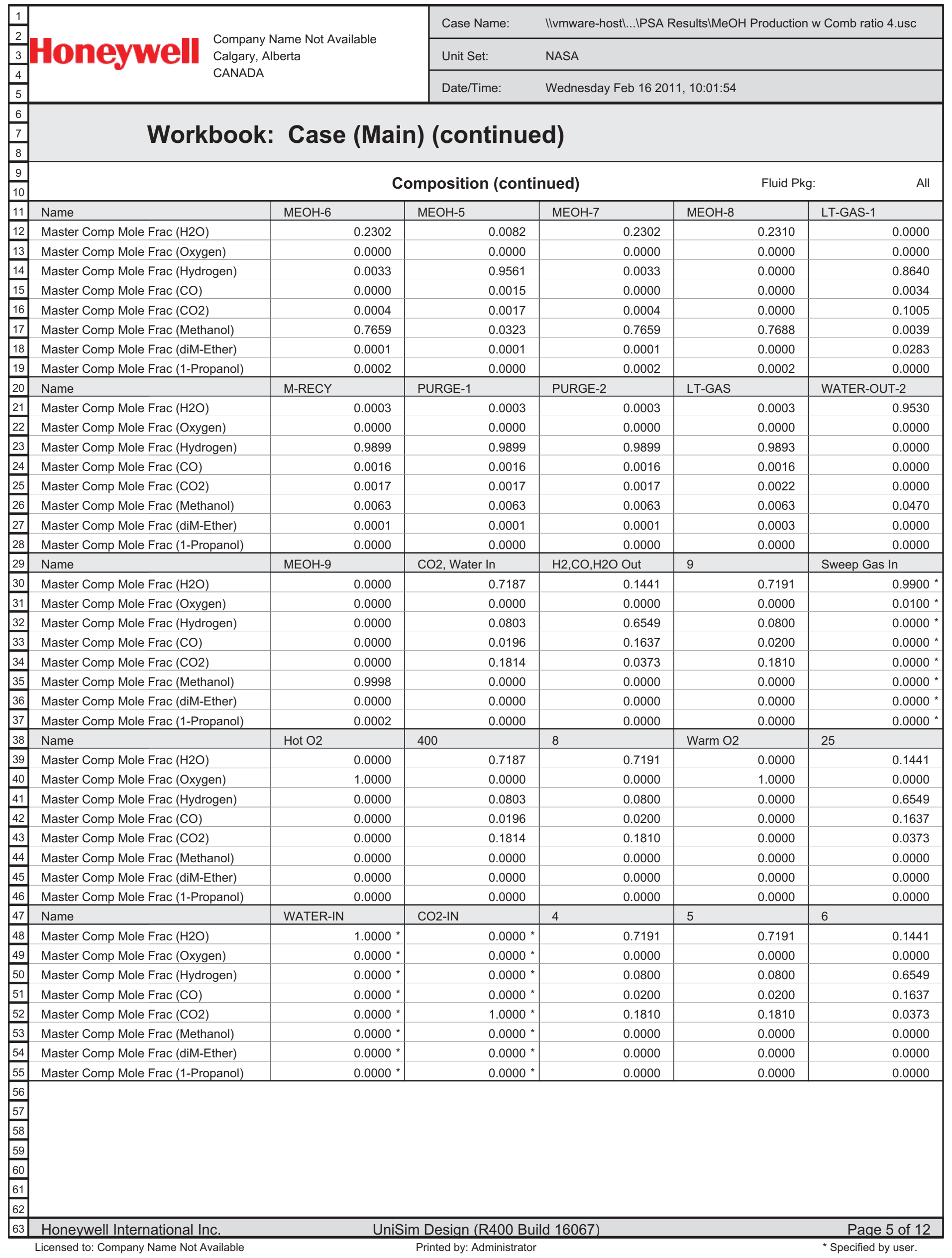




\begin{tabular}{|c|c|c|c|c|c|c|}
\hline 1 & & & Case Name: & IIvmware-hostl...IPSA & esults $\mid \mathrm{MeOH}$ Production & w Comb ratio 4 .usc \\
\hline 3 & DOCNWE Calgar & perta & Unit Set: & NASA & & \\
\hline$\frac{7}{5}$ & URIVI & & Date/Time: & Wednesday Feb 1620 & $1,10: 01: 54$ & \\
\hline$\frac{6}{\frac{7}{8}}$ & Workboo & Case (Ma & ) (continue & d) & & \\
\hline$\frac{9}{10}$ & & & mposition (contir & hued) & Fluid Pkg & All \\
\hline 11 & Name & 7 & 10 & SYNG-1 & 13 & 14 \\
\hline 12 & Master Comp Mole Frac $(\mathrm{H} 2 \mathrm{O})$ & 0.1441 & 0.1441 & 0.0260 & 0.9999 & 0.9999 \\
\hline 13 & Master Comp Mole Frac (Oxygen) & 0.0000 & 0.0000 & 0.0000 & 0.0000 & 0.0000 \\
\hline 14 & Master Comp Mole Frac (Hydrogen) & 0.6549 & 0.6549 & 0.7453 & 0.0001 & 0.0001 \\
\hline 15 & Master Comp Mole Frac (CO) & 0.1637 & 0.1637 & 0.1863 & 0.0000 & 0.0000 \\
\hline 16 & Master Comp Mole Frac (CO2) & 0.0373 & 0.0373 & 0.0424 & 0.0000 & 0.0000 \\
\hline 17 & Master Comp Mole Frac (Methanol) & 0.0000 & 0.0000 & 0.0000 & 0.0000 & 0.0000 \\
\hline 18 & Master Comp Mole Frac (diM-Ether) & 0.0000 & 0.0000 & 0.0000 & 0.0000 & 0.0000 \\
\hline 19 & Master Comp Mole Frac (1-Propanol) & 0.0000 & 0.0000 & 0.0000 & 0.0000 & 0.0000 \\
\hline 20 & Name & SYNG-RCY & O2-OUT & 18 & 17 & 11 \\
\hline 21 & Master Comp Mole Frac $(\mathrm{H} 2 \mathrm{O})$ & 0.5427 & 0.0000 & 0.7191 & $0.7191^{*}$ & 0.1441 \\
\hline 22 & Master Comp Mole Frac (Oxygen) & 0.0000 & 1.0000 & 0.0000 & $0.0000 *$ & 0.0000 \\
\hline 23 & Master Comp Mole Frac (Hydrogen) & 0.3499 & 0.0000 & 0.0800 & $0.0800 *$ & 0.6549 \\
\hline 24 & Master Comp Mole Frac (CO) & 0.0875 & 0.0000 & 0.0200 & $0.0200 *$ & 0.1637 \\
\hline 25 & Master Comp Mole Frac (CO2) & 0.0199 & 0.0000 & 0.1810 & $0.1810 *$ & 0.0373 \\
\hline 26 & Master Comp Mole Frac (Methanol) & 0.0000 & 0.0000 & 0.0000 & $0.0000 *$ & 0.0000 \\
\hline 27 & Master Comp Mole Frac (diM-Ether) & 0.0000 & 0.0000 & 0.0000 & $0.0000 *$ & 0.0000 \\
\hline 28 & Master Comp Mole Frac (1-Propanol) & 0.0000 & 0.0000 & 0.0000 & $0.0000 *$ & 0.0000 \\
\hline 29 & Name & 19 & 20 & 21 & 22 & 23 \\
\hline 30 & Master Comp Mole Frac (H2O) & 0.0260 & 0.0260 & 0.0260 & 0.0260 & 0.0260 \\
\hline 31 & Master Comp Mole Frac (Oxygen) & 0.0000 & 0.0000 & 0.0000 & 0.0000 & 0.0000 \\
\hline 32 & Master Comp Mole Frac (Hydrogen) & 0.7453 & 0.7453 & 0.7453 & 0.7453 & 0.7453 \\
\hline 33 & Master Comp Mole Frac (CO) & 0.1863 & 0.1863 & 0.1863 & 0.1863 & 0.1863 \\
\hline 34 & Master Comp Mole Frac (CO2) & 0.0424 & 0.0424 & 0.0424 & 0.0424 & 0.0424 \\
\hline 35 & Master Comp Mole Frac (Methanol) & 0.0000 & 0.0000 & 0.0000 & 0.0000 & 0.0000 \\
\hline 36 & Master Comp Mole Frac (diM-Ether) & 0.0000 & 0.0000 & 0.0000 & 0.0000 & 0.0000 \\
\hline 37 & Master Comp Mole Frac (1-Propanol) & 0.0000 & 0.0000 & 0.0000 & 0.0000 & 0.0000 \\
\hline 38 & Name & 24 & 26 & 27 & 12 & COMB-PROD \\
\hline 39 & Master Comp Mole Frac $(\mathrm{H} 2 \mathrm{O})$ & 0.0260 & 0.0260 & 0.0260 & $0.0032 *$ & 0.9897 \\
\hline 40 & Master Comp Mole Frac (Oxygen) & 0.0000 & 0.0000 & 0.0000 & $0.0000 *$ & 0.0001 \\
\hline 41 & Master Comp Mole Frac (Hydrogen) & 0.7453 & 0.7453 & 0.7453 & $0.9629 *$ & 0.0000 \\
\hline 42 & Master Comp Mole Frac (CO) & 0.1863 & 0.1863 & 0.1863 & $0.0220 *$ & 0.0000 \\
\hline 43 & Master Comp Mole Frac (CO2) & 0.0424 & 0.0424 & 0.0424 & $0.0062 *$ & 0.0099 \\
\hline 44 & Master Comp Mole Frac (Methanol) & 0.0000 & 0.0000 & 0.0000 & $0.0056 *$ & 0.0000 \\
\hline 45 & Master Comp Mole Frac (diM-Ether) & 0.0000 & 0.0000 & 0.0000 & $0.0001 *$ & 0.0003 \\
\hline 46 & Master Comp Mole Frac (1-Propanol) & 0.0000 & 0.0000 & 0.0000 & $0.0000 *$ & 0.0000 \\
\hline 47 & Name & 28 & $\mathrm{O} 2-\mathrm{IN}-1$ & WATER-OUT-1 & CO2-OUT & COMB-PROD-2 \\
\hline 48 & Master Comp Mole Frac (H2O) & 0.9897 & $0.0000 *$ & 0.9994 & 0.0259 & 0.6664 \\
\hline 49 & Master Comp Mole Frac (Oxygen) & 0.0001 & $1.0000 *$ & 0.0000 & 0.0013 & 0.0004 \\
\hline 50 & Master Comp Mole Frac (Hydrogen) & 0.0000 & $0.0000 *$ & 0.0000 & 0.0000 & 0.0000 \\
\hline 51 & Master Comp Mole Frac (CO) & 0.0000 & $0.0000 *$ & 0.0000 & 0.0000 & 0.0000 \\
\hline 52 & Master Comp Mole Frac (CO2) & 0.0099 & $0.0000 *$ & 0.0006 & 0.9723 & 0.3332 \\
\hline 53 & Master Comp Mole Frac (Methanol) & 0.0000 & $0.0000 *$ & 0.0000 & 0.0000 & 0.0000 \\
\hline 54 & Master Comp Mole Frac (diM-Ether) & 0.0003 & $0.0000 *$ & 0.0000 & 0.0003 & 0.0000 \\
\hline 55 & Master Comp Mole Frac (1-Propanol) & 0.0000 & $0.0000 *$ & 0.0000 & 0.0002 & 0.0001 \\
\hline \begin{tabular}{|l|}
56 \\
57 \\
58 \\
59 \\
60 \\
61 \\
62 \\
\end{tabular} & & & & & & \\
\hline 63 & Honeywell International Inc. & Uni & n Design (R400 Buil & Id 16067) & & Page 6 of 12 \\
\hline
\end{tabular}




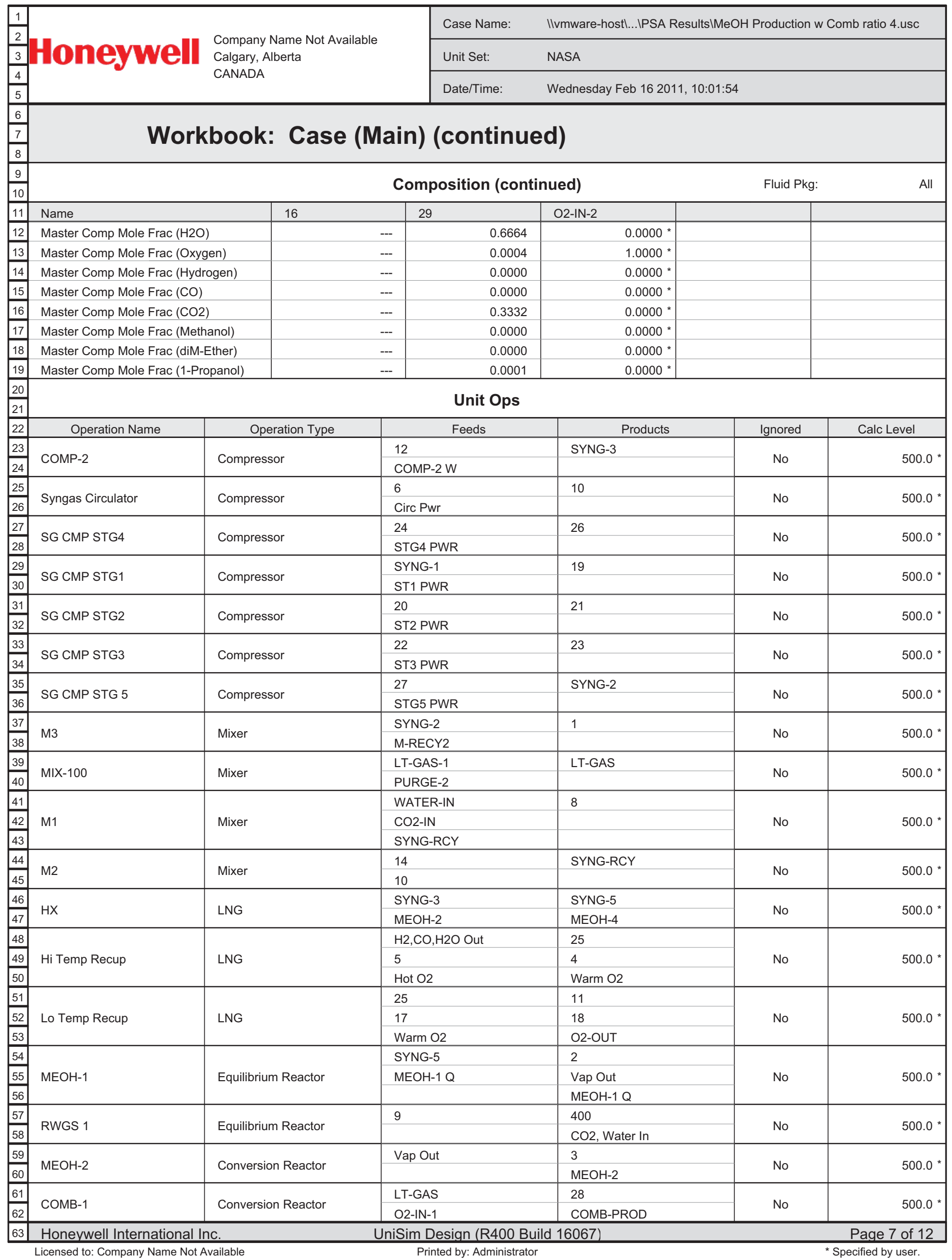




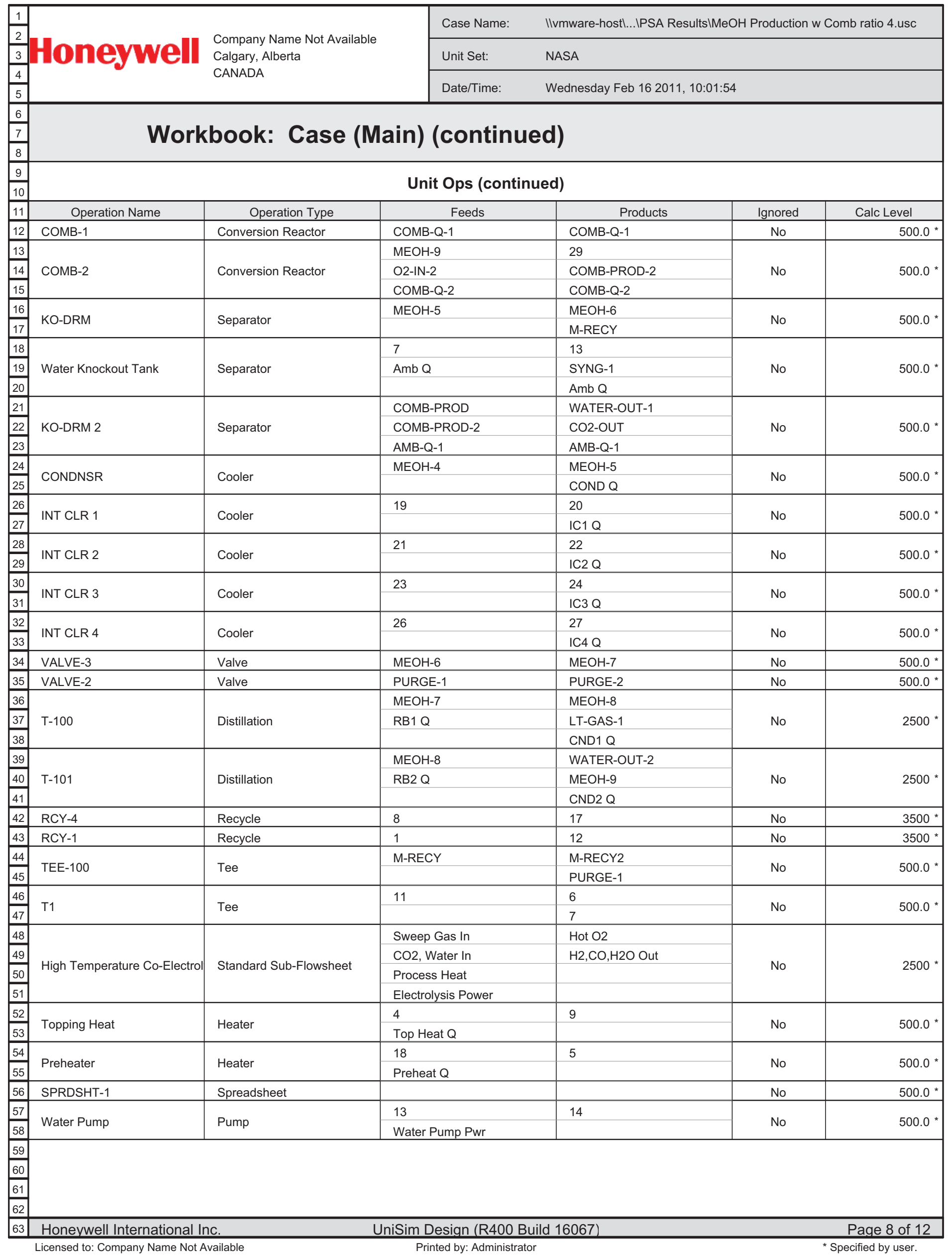




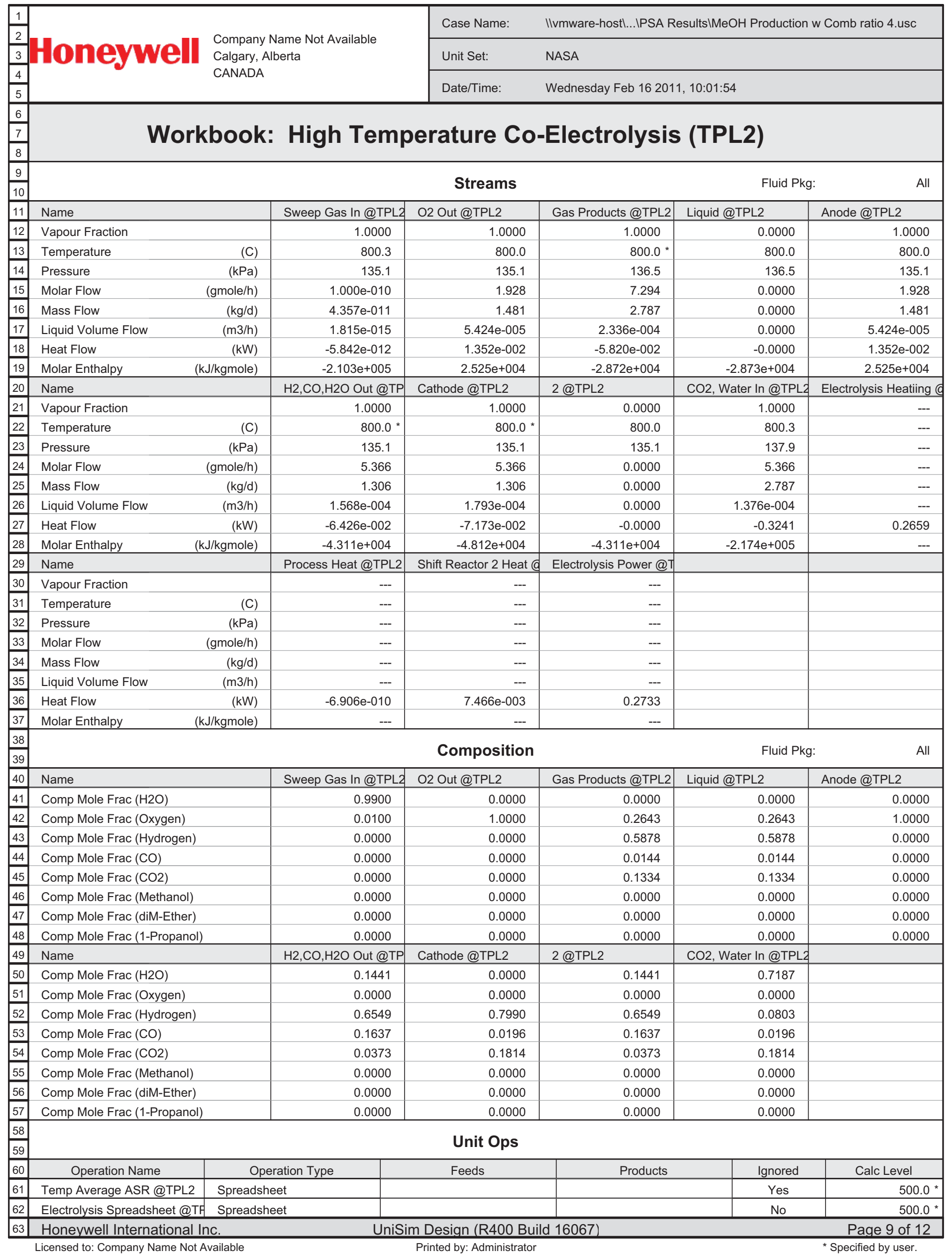




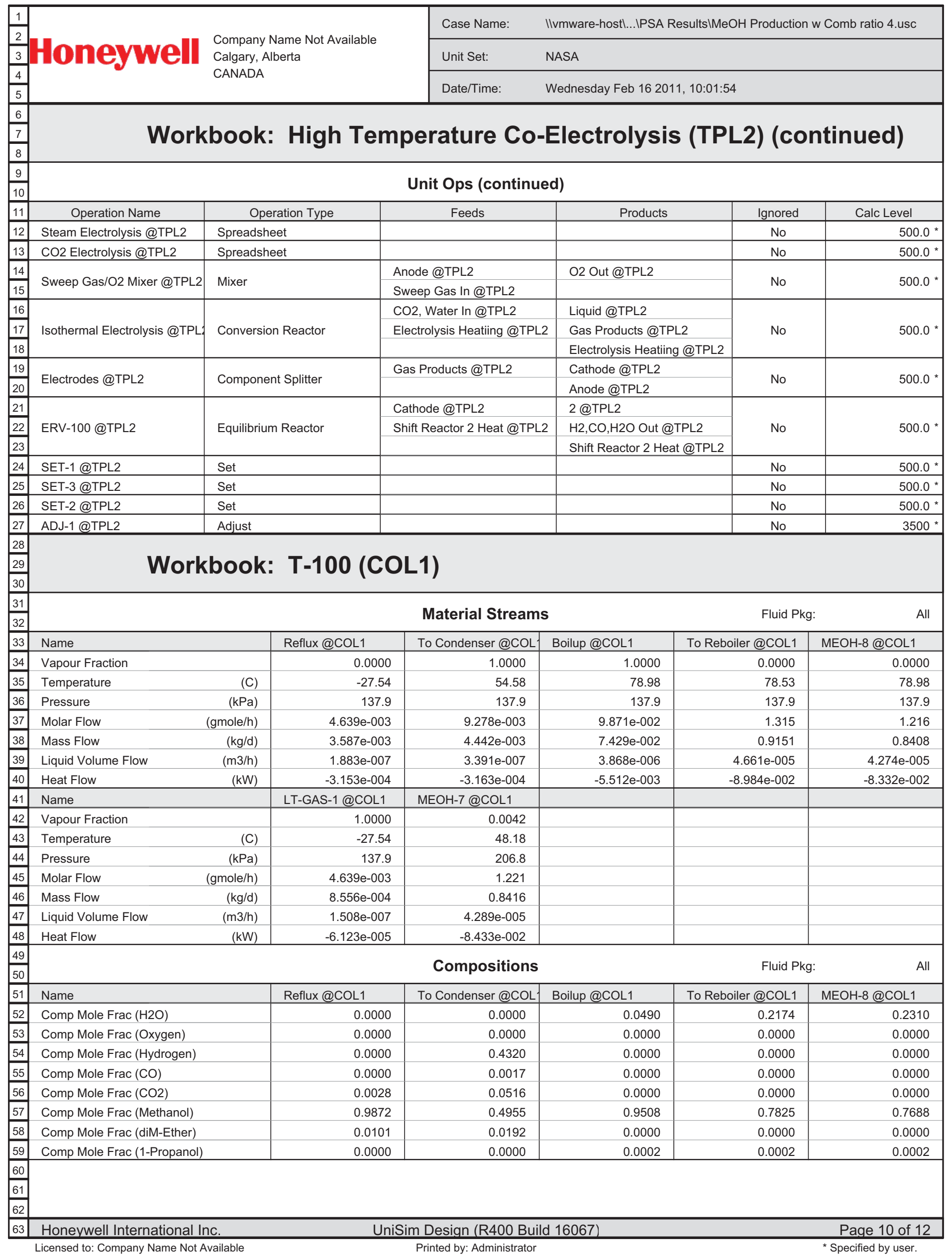




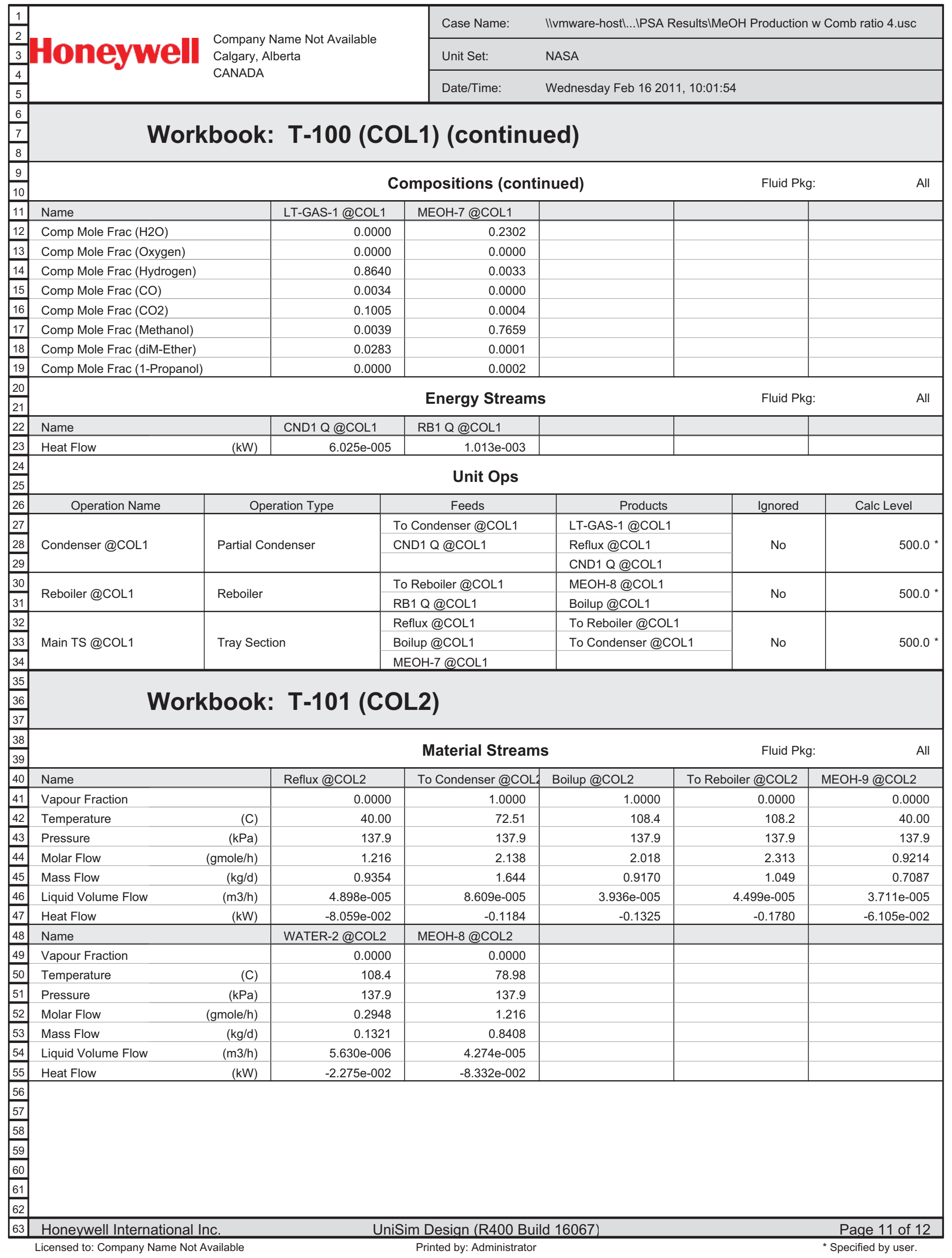




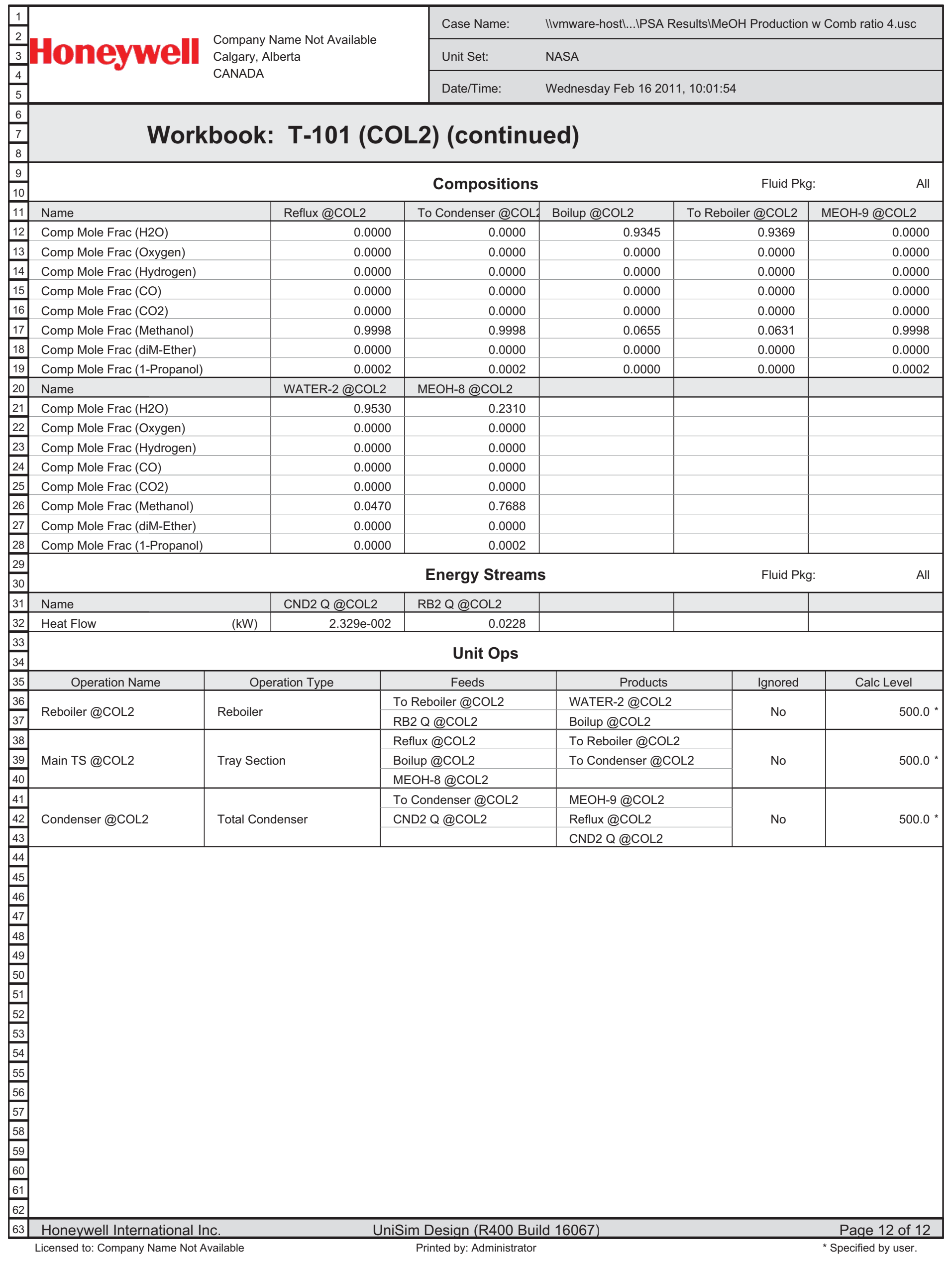




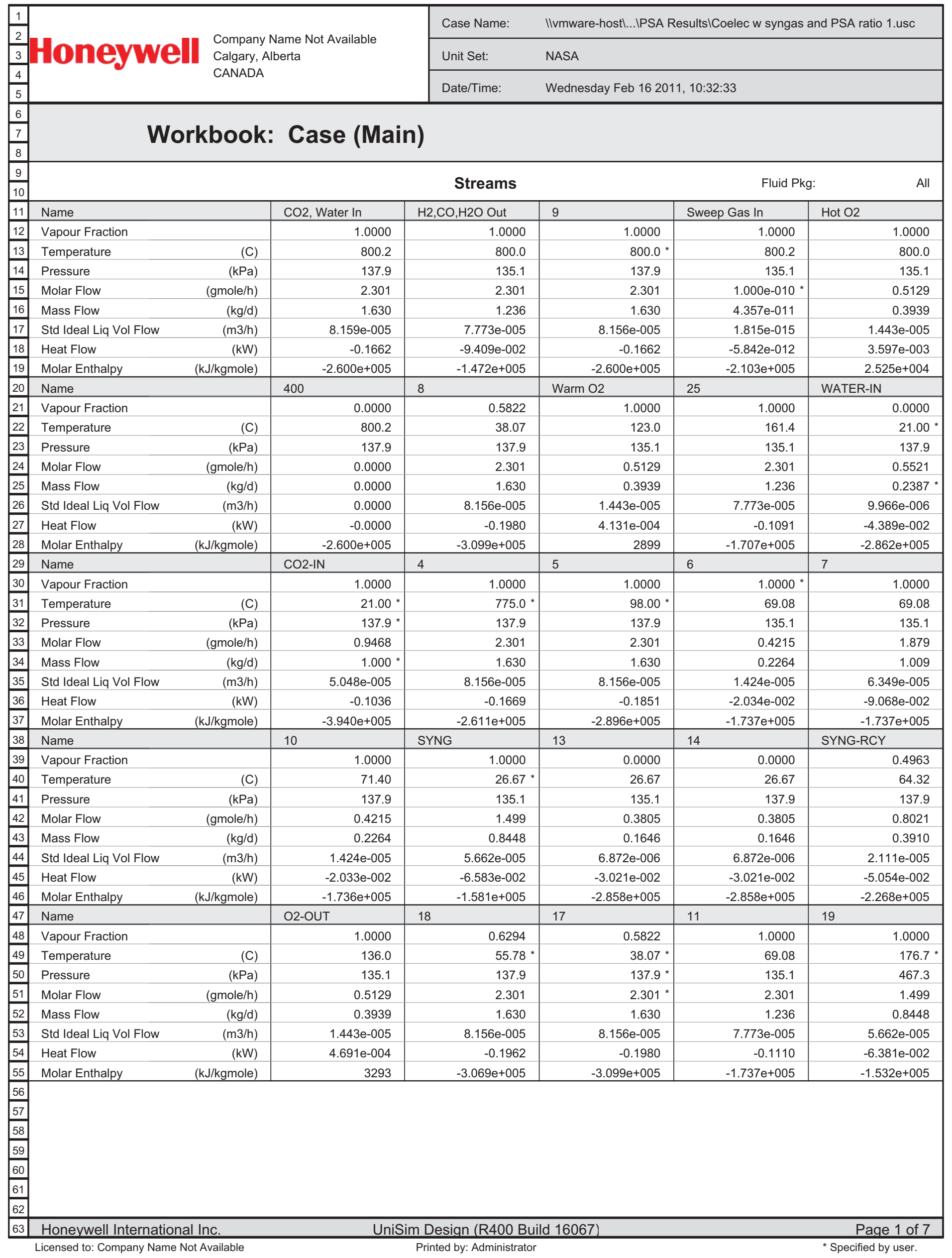




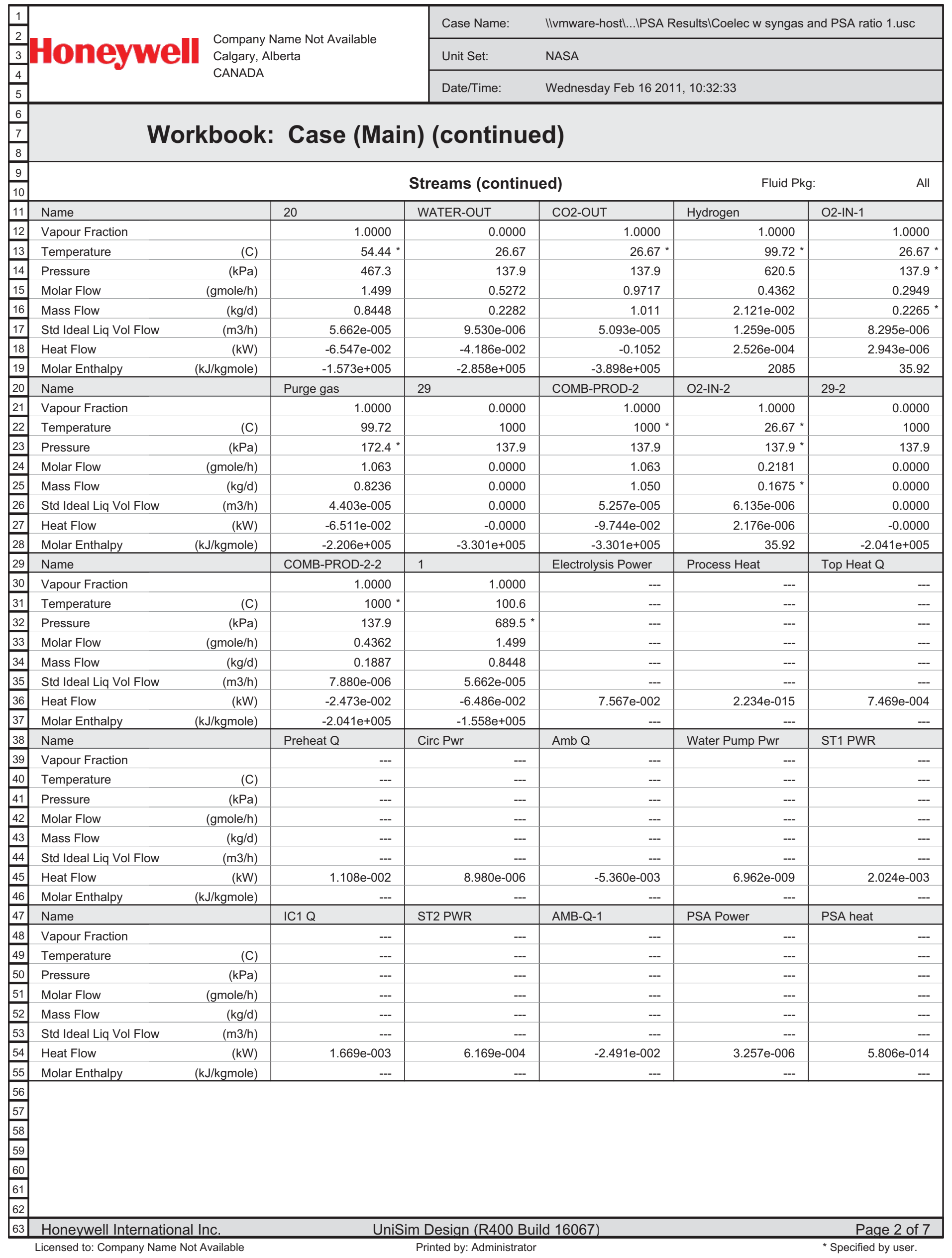




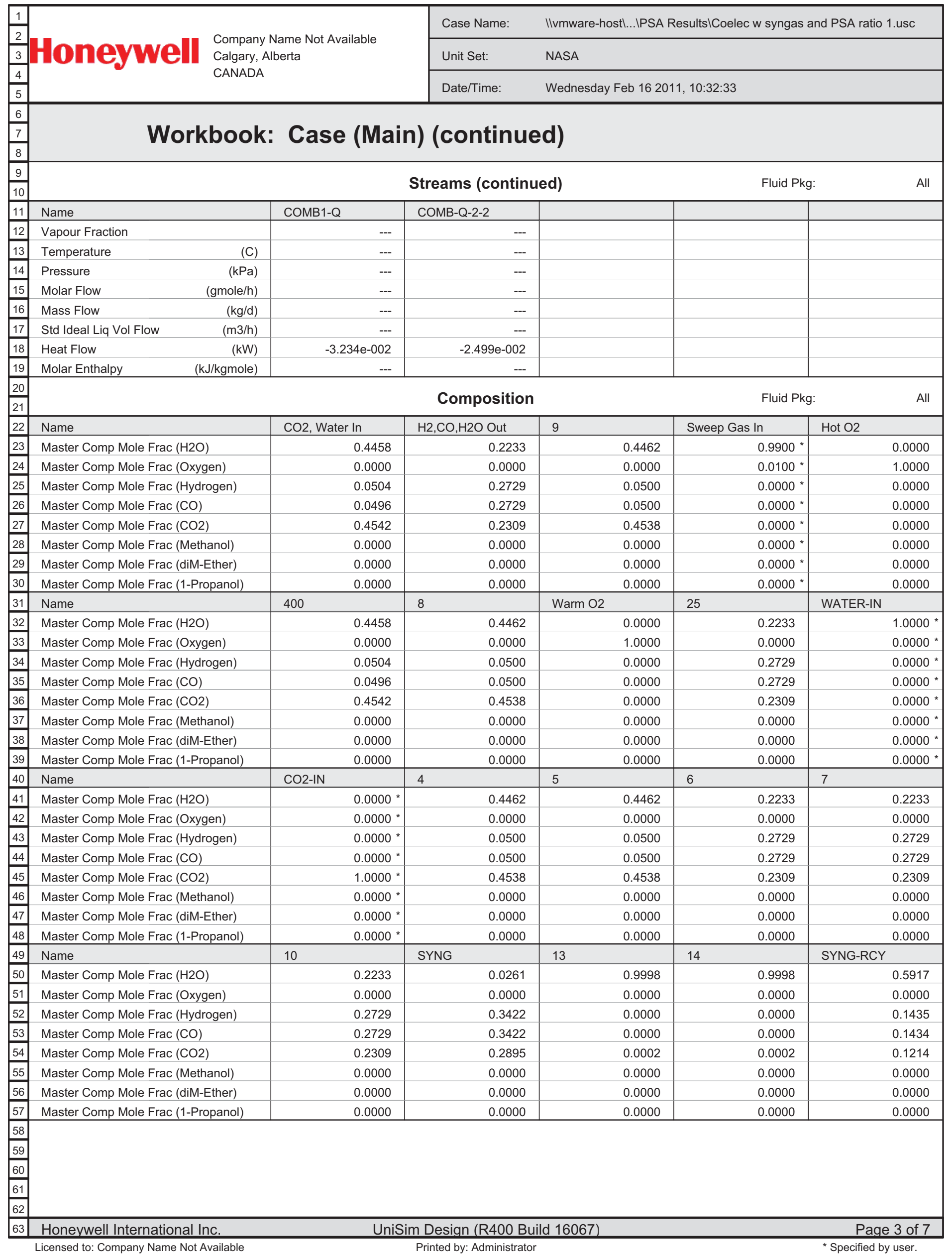




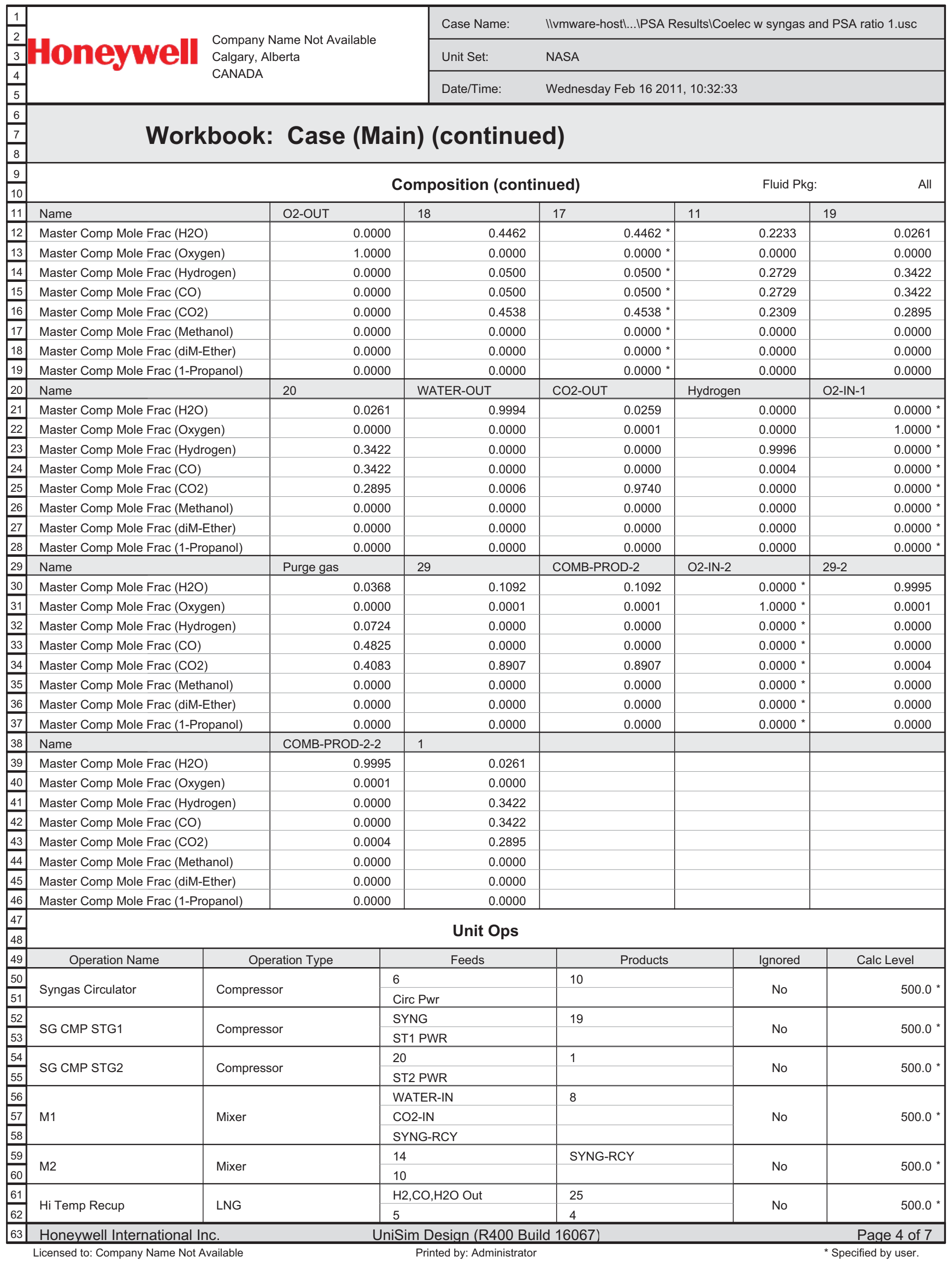




\begin{tabular}{|c|c|c|c|c|c|c|}
\hline 1 & & \multirow{3}{*}{$\begin{array}{l}\text { Company Name Not Availabl } \\
\text { Calgary, Alberta } \\
\text { CANADA }\end{array}$} & Case Name: & \\
\hline 3 & & & Unit Set: & \multicolumn{3}{|c|}{$\begin{array}{l}\text { IIvmware-hostl...IPSA ResultsICoelec w syngas and PSA ratio 1.usc } \\
\text { NASA }\end{array}$} \\
\hline 5 & & & Date/Time: & \multicolumn{3}{|c|}{ Wednesday Feb 16 2011, 10:32:33 } \\
\hline$\frac{6}{7}$ & \multicolumn{6}{|c|}{ Workbook: Case (Main) (continued) } \\
\hline \begin{tabular}{|c|}
9 \\
10
\end{tabular} & \multicolumn{6}{|c|}{ Unit Ops (continued) } \\
\hline 11 & Operation Name & Operation Type & Feeds & Products & Ignored & Calc Level \\
\hline 12 & Hi Temp Recup & LNG & Hot O2 & Warm O2 & No & 500.0 * \\
\hline 13 & \multirow{3}{*}{ Lo Temp Recup } & \multirow{3}{*}{ LNG } & 25 & 11 & \multirow{3}{*}{ No } & \multirow{3}{*}{500.0} \\
\hline 14 & & & 17 & 18 & & \\
\hline 15 & & & Warm O2 & O2-OUT & & \\
\hline 16 & \multirow{2}{*}{ RWGS 1} & \multirow{2}{*}{ Equilibrium Reactor } & 9 & 400 & \multirow{2}{*}{ No } & 5000 * \\
\hline 17 & & & & $\mathrm{CO} 2$, Water In & & 500.0 \\
\hline 18 & & & $\mathrm{O} 2-\mathrm{IN}-1$ & 29 & & \\
\hline 19 & COMBUSTOR 1 & Conversion Reactor & Purge gas & COMB-PROD-2 & No & 500.0 * \\
\hline 20 & & & COMB1-Q & COMB1-Q & & \\
\hline 21 & & & $\mathrm{O} 2-\mathrm{IN}-2$ & $29-2$ & & \\
\hline 22 & COMBUSTOR 2 & Conversion Reactor & Hydrogen & COMB-PROD-2-2 & No & 500.0 * \\
\hline 23 & & & COMB-Q-2-2 & COMB-Q-2-2 & & \\
\hline 24 & & & 7 & 13 & & \\
\hline 25 & Water Knockout Tank & Separator & Amb Q & SYNG & No & 500.0 * \\
\hline 26 & & & & $\mathrm{Amb} Q$ & & \\
\hline 27 & & & COMB-PROD-2 & WATER-OUT & & \\
\hline 28 & KO-DRM 2 & Separator & COMB-PROD-2-2 & CO2-OUT & No & 500.0 * \\
\hline 29 & & & AMB-Q-1 & AMB-Q-1 & & \\
\hline 30 & INT CI R 1 & Cooler & 19 & 20 & $\mathrm{No}$ & 5000 * \\
\hline 31 & INT CLR I & coorer & & $\mathrm{IC} 1 \mathrm{Q}$ & NO & 500.0 \\
\hline 32 & $\mathrm{RCY}-4$ & Recycle & 8 & 17 & No & $3500 *$ \\
\hline 33 & & & 11 & 6 & & \\
\hline 34 & 17 & lee & & 7 & No & 500.0 \\
\hline 35 & & & Sweep Gas In & Hot O2 & & \\
\hline 36 & & & $\mathrm{CO} 2$, Water In & $\mathrm{H} 2, \mathrm{CO}, \mathrm{H} 2 \mathrm{O}$ Out & & 2500 * \\
\hline 37 & High I emperature Co-Electrol & Standard Sub-rlowsheet & Process Heat & & No & 2500 \\
\hline 38 & & & Electrolysis Power & & & \\
\hline 39 & Tonning Heat & Heater & 4 & 9 & & 5000 * \\
\hline 40 & Iopping Heat & Heater & Top Heat Q & & No & 500.0 \\
\hline 41 & & & 18 & 5 & & \\
\hline 42 & Preheater & Heater & Preheat Q & & No & $500.0=$ \\
\hline 43 & SPRDSHT-1 & Spreadsheet & & & No & 500.0 * \\
\hline 44 & PSA Calcs & Spreadsheet & & & No & $500.0^{*}$ \\
\hline 45 & Water Pumn & Pump & 13 & 14 & & 5000 * \\
\hline 46 & Water Pump & Pump & Water Pump Pwr & & No & 500.0 \\
\hline 47 & & & 1 & Hydrogen & & \\
\hline 48 & PSA & Component Splitter & PSA Power & Purge gas & No & 500.0 * \\
\hline 49 & & & PSA heat & & & \\
\hline 50 & SET-1 & Set & & & No & 500.0 * \\
\hline 51 & ADJ-1 & Adjust & & & No & 3500 * \\
\hline 52 & & & & & & \\
\hline 53 & & & & & & \\
\hline 54 & & & & & & \\
\hline 56 & & & & & & \\
\hline 57 & & & & & & \\
\hline 58 & & & & & & \\
\hline 60 & & & & & & \\
\hline 61 & & & & & & \\
\hline 63 & Honeywell International In & c. & niSim Design (R400 & ild 16067) & & Page 5 of 7 \\
\hline & Licensed to: Company Name Not A & vailable & Printed by: Administ & & & ecified by user. \\
\hline
\end{tabular}




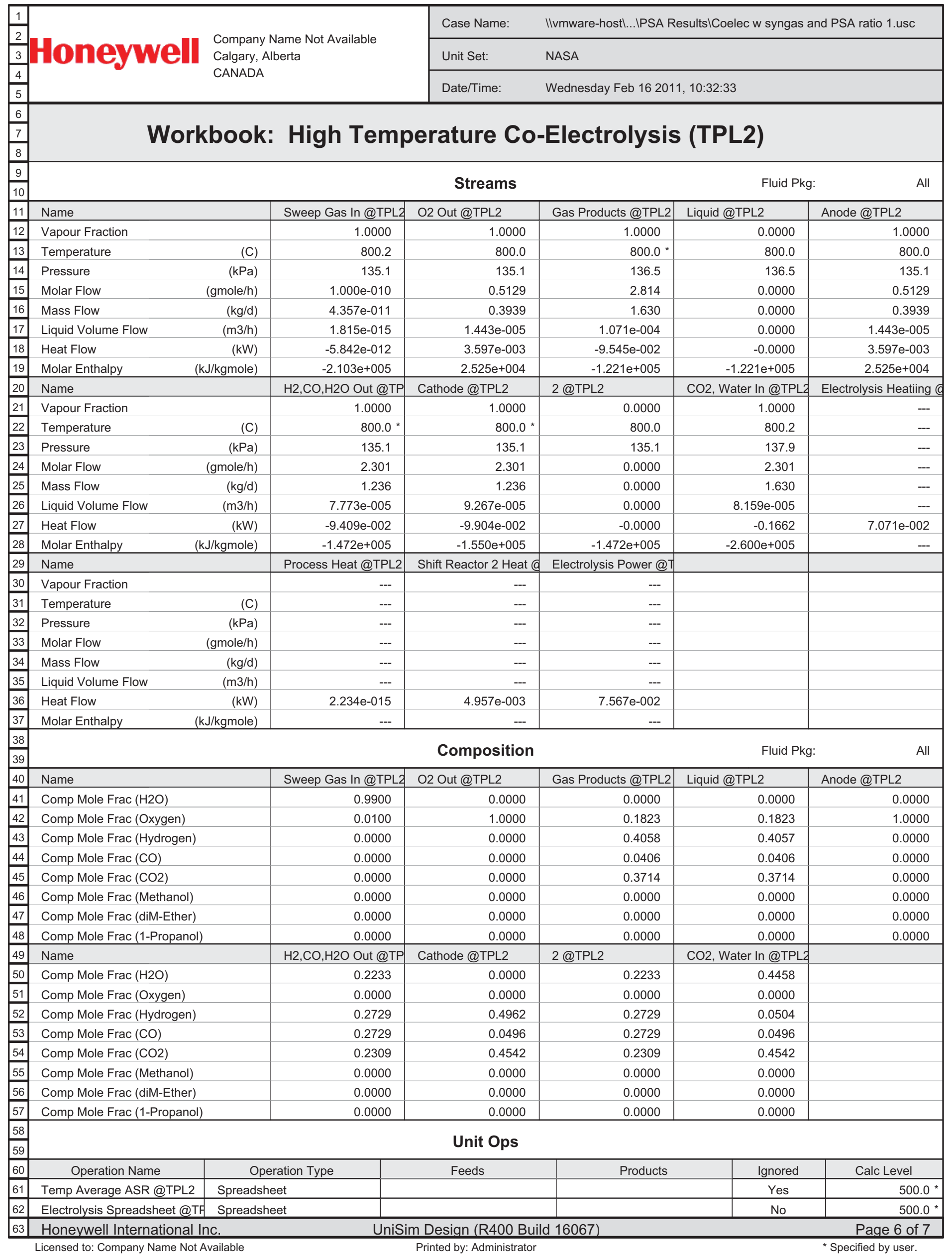




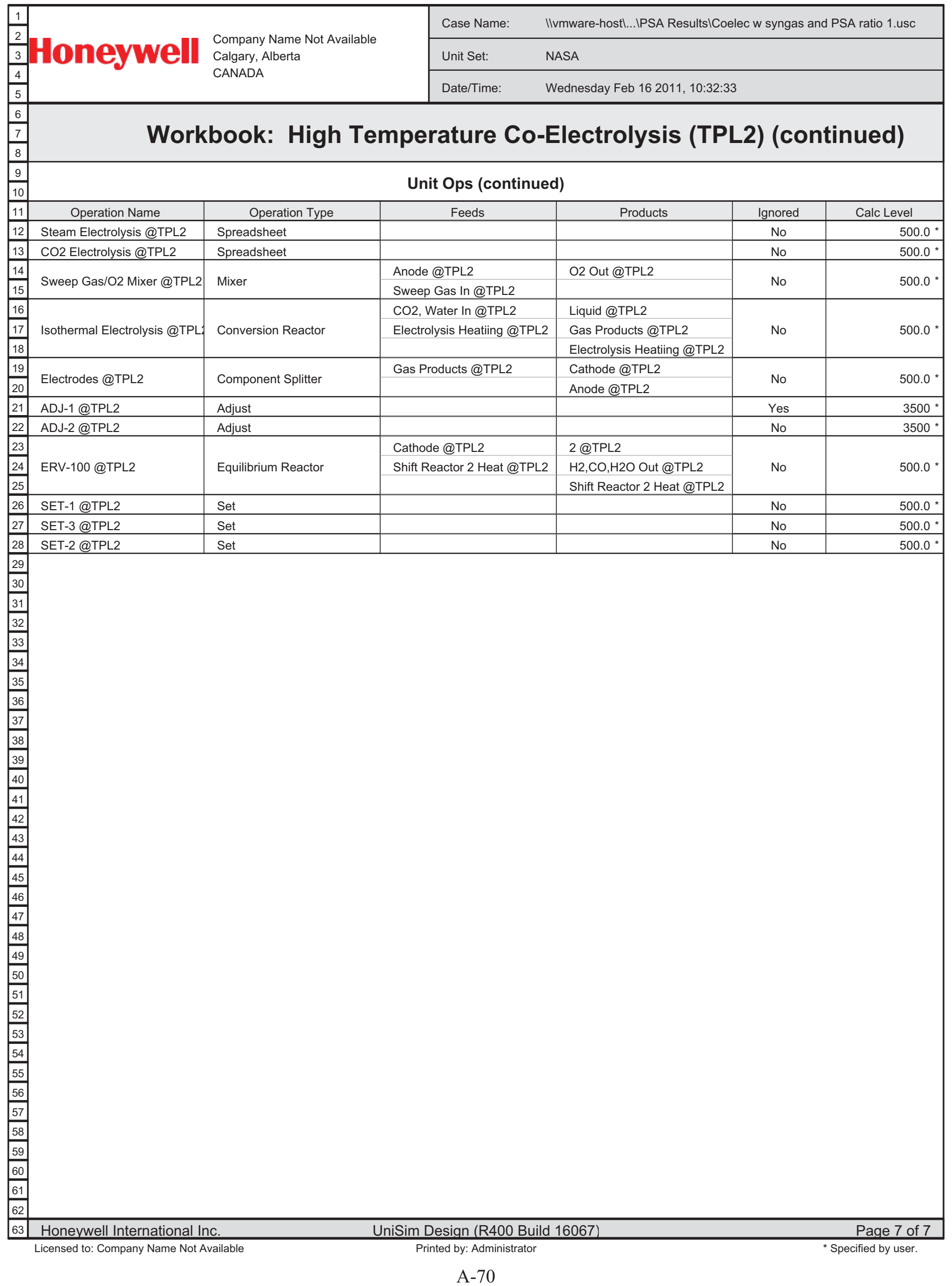




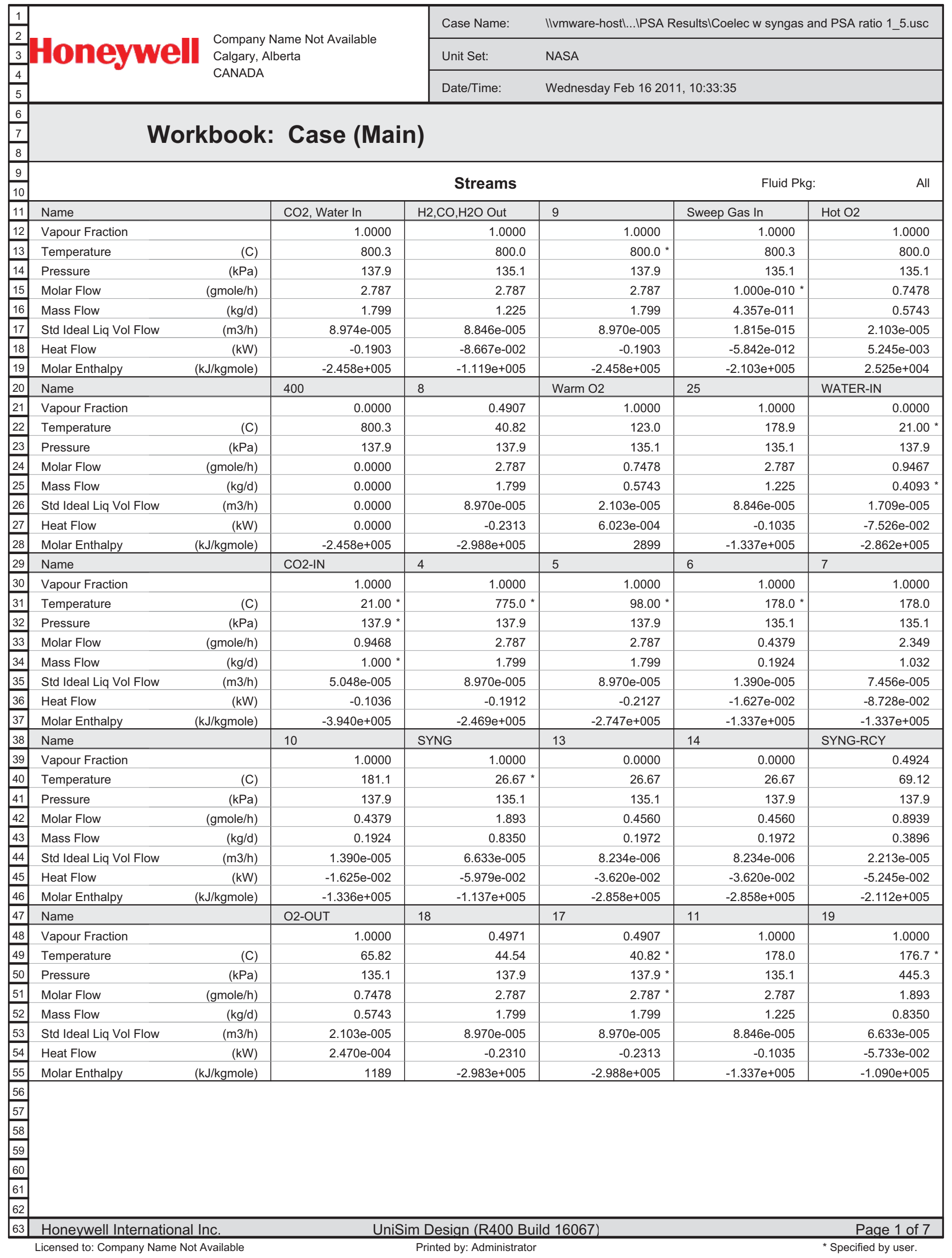




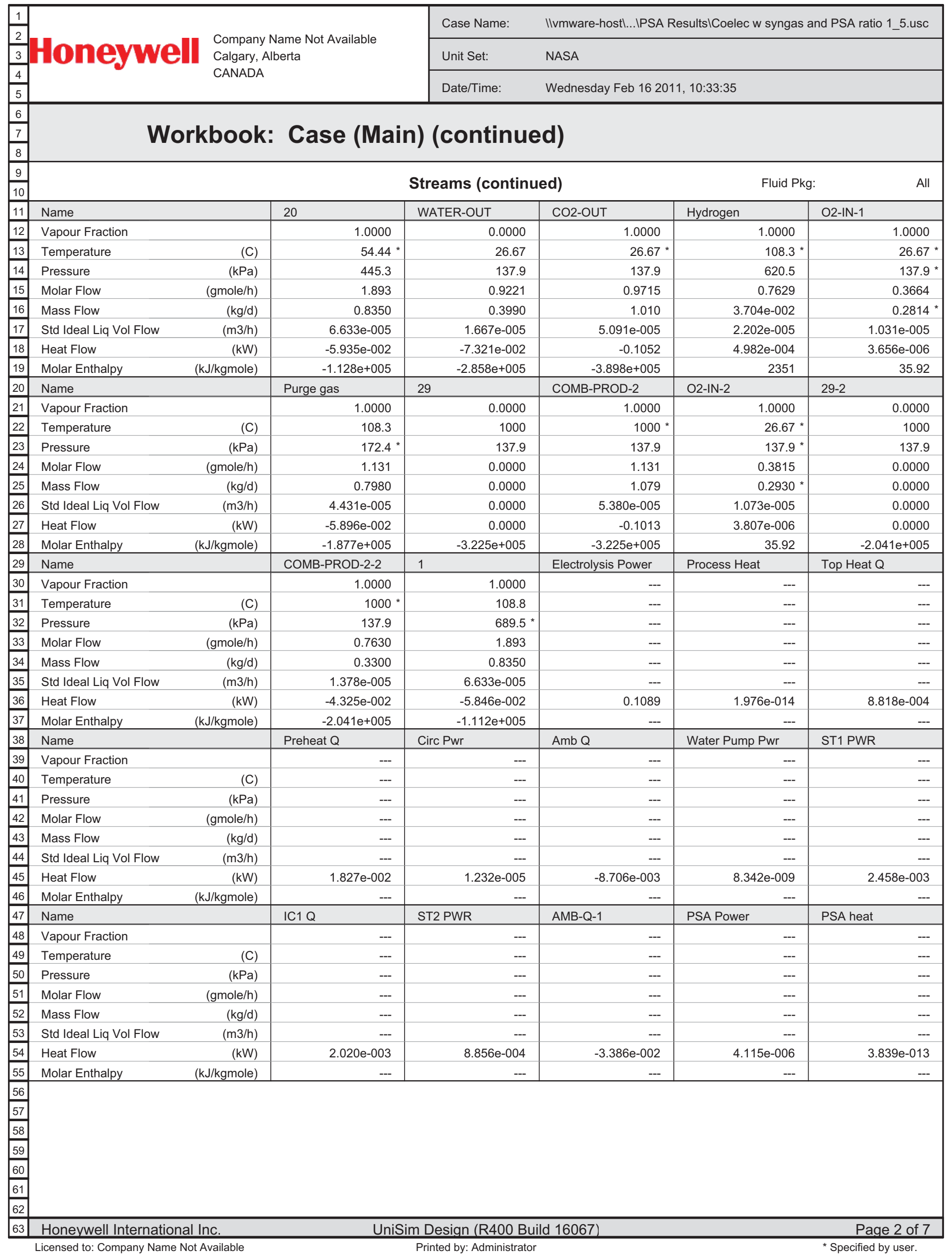




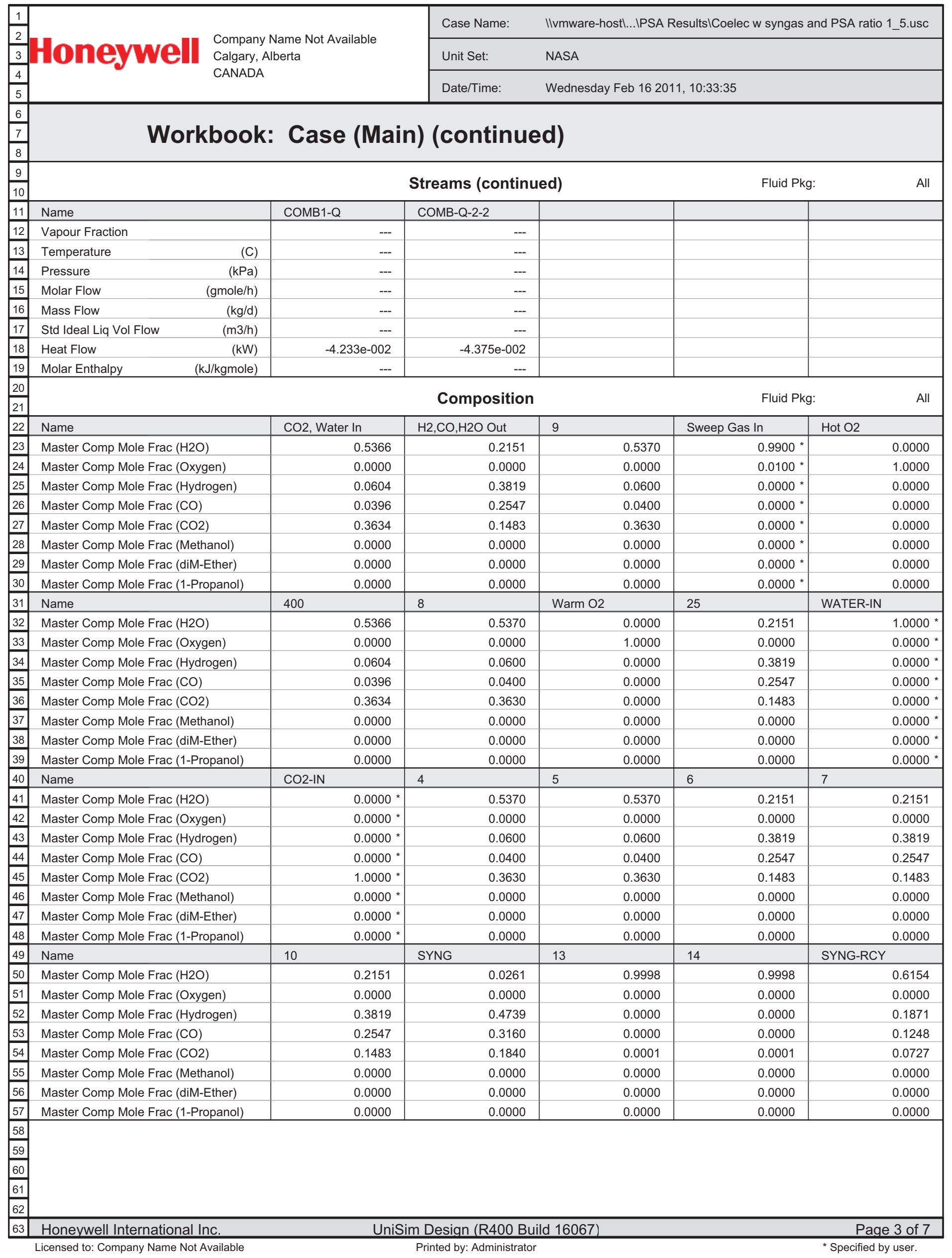




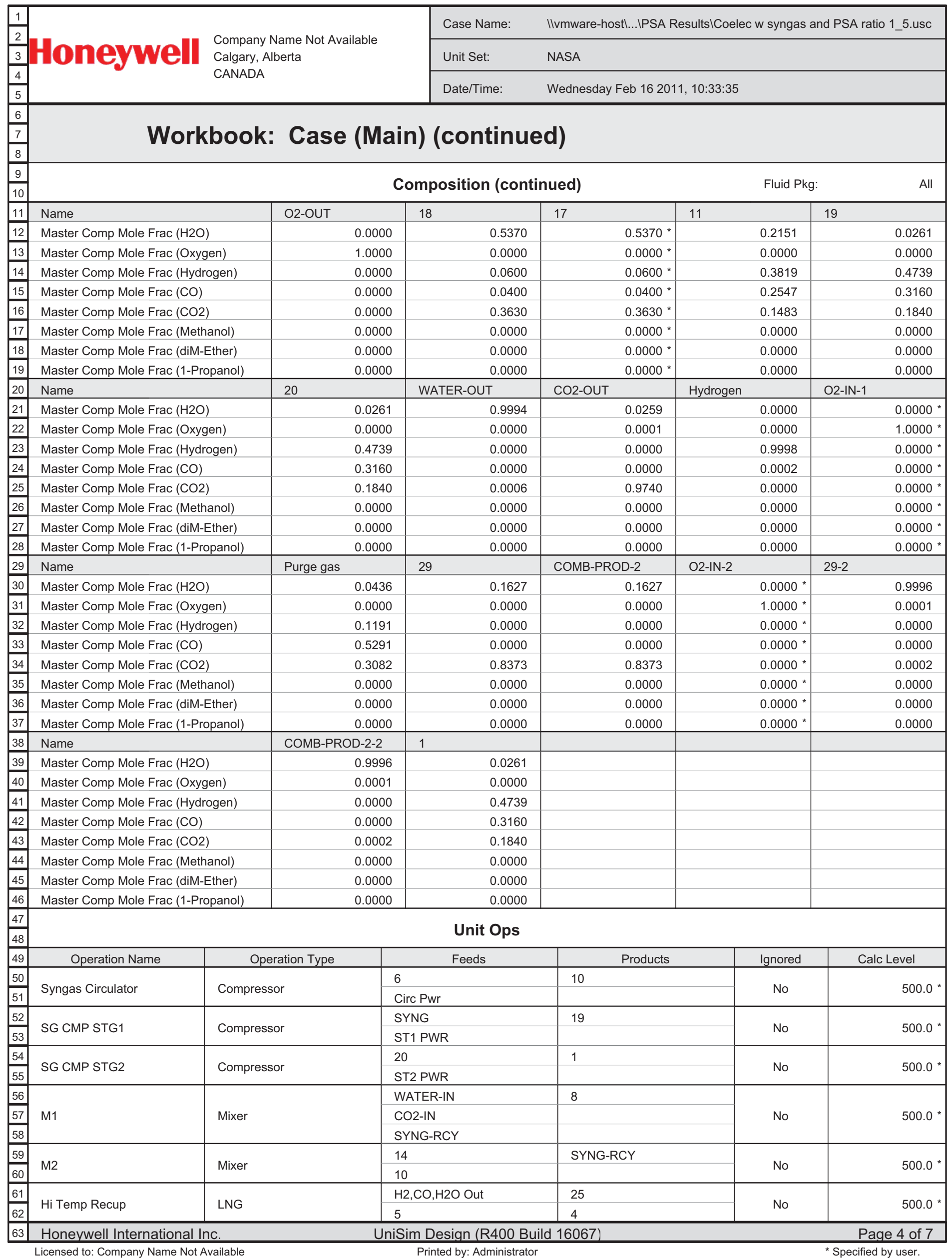




\begin{tabular}{|c|c|c|c|c|c|c|}
\hline \multirow{2}{*}{\begin{tabular}{|l|}
1 \\
2 \\
3
\end{tabular}} & \multirow{3}{*}{$\begin{array}{l}\text { Company Name Not Available } \\
\text { Calgary, Alberta } \\
\text { CANADA }\end{array}$} & \multirow{3}{*}{$\begin{array}{l}\text { Company Name Not Available } \\
\text { Calgary, Alberta } \\
\text { CANADA }\end{array}$} & Case Name: & \\
\hline & & & Unit Set: & \multicolumn{3}{|c|}{ IIvmware-host|...IPSA Results|Coelec w syngas and PSA ratio 1_5.usc } \\
\hline$\frac{4}{5}$ & & & Date/Time: & \multicolumn{3}{|c|}{ Wednesday Feb 16 2011, 10:33:35 } \\
\hline$\frac{6}{7}$ & \multicolumn{6}{|c|}{ Workbook: Case (Main) (continued) } \\
\hline$\frac{9}{10}$ & \multicolumn{6}{|c|}{ Unit Ops (continued) } \\
\hline 11 & Operation Name & Operation Type & Feeds & Products & Ignored & Calc Level \\
\hline 12 & Hi Temp Recup & LNG & Hot O2 & Warm O2 & No & 500.0 * \\
\hline 13 & \multirow{3}{*}{ Lo Temp Recup } & \multirow{3}{*}{ LNG } & 25 & 11 & \multirow{3}{*}{ No } & \multirow{3}{*}{$500.0 *$} \\
\hline 14 & & & 17 & 18 & & \\
\hline 15 & & & Warm O2 & O2-OUT & & \\
\hline 16 & \multirow{2}{*}{ RWGS 1} & \multirow{2}{*}{ Equilibrium Reactor } & 9 & 400 & $\mathrm{Ne}$ & 5000 * $>2>0$ \\
\hline 17 & & & & $\mathrm{CO} 2$, Water In & NO & 500.0 \\
\hline 18 & & & O2-IN-1 & 29 & & \\
\hline 19 & COMBUSTOR 1 & Conversion Reactor & Purge gas & COMB-PROD-2 & No & $500.0 *$ \\
\hline 20 & & & COMB1-Q & COMB1-Q & & \\
\hline 21 & & & O2-IN-2 & $29-2$ & & \\
\hline 22 & COMBUSTOR 2 & Conversion Reactor & Hydrogen & COMB-PROD-2-2 & No & 500.0 * \\
\hline 23 & & & COMB-Q-2-2 & COMB-Q-2-2 & & \\
\hline 24 & & & 7 & 13 & & \\
\hline 25 & Water Knockout Tank & Separator & $A m b$ Q & SYNG & No & 500.0 * \\
\hline 26 & & & & Amb Q & & \\
\hline 27 & & & COMB-PROD-2 & WATER-OUT & & \\
\hline 28 & KO-DRM 2 & Separator & COMB-PROD-2-2 & CO2-OUT & No & 500.0 * \\
\hline 29 & & & AMB-Q-1 & AMB-Q-1 & & \\
\hline 30 & INT CIP 1 & Coolor $\mathrm{r}, \mathrm{C}>\mathrm{C}$ & 19 & 20 & $\mathrm{Ne}$ & 5000 * $>2 \div$ \\
\hline 31 & IVI CLR I & coorer & & $\mathrm{IC} 1 \mathrm{Q}$ & NO & 500.0 \\
\hline 32 & RCY -4 & Recycle & 8 & 17 & No & 3500 * \\
\hline 33 & & & 11 & 6 & & 5000 * $>2>0$ \\
\hline 34 & 11 & lee & & 7 & No & 500.0 \\
\hline 35 & & & Sweep Gas In & Hot O2 & & \\
\hline 36 & Hiah Temnerature Co-Flectrol & Standard Suh_Flowsheet & $\mathrm{CO} 2$, Water In & $\mathrm{H} 2, \mathrm{CO}, \mathrm{H} 2 \mathrm{O}$ Out & $\mathrm{No}$ & $2500 *$ \\
\hline 37 & 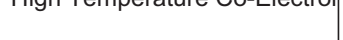 & 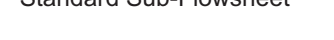 & Process Heat & & No & 2000 \\
\hline 38 & & & Electrolysis Power & & & \\
\hline 39 & Topning Heat & Heater & 4 & 9 & & 5000 * \\
\hline 40 & Iopping Heat & Heater & Top Heat Q & & No & $500.0 *$ \\
\hline 41 & & & 18 & 5 & & 5000 * \\
\hline 42 & Preheater & Heater & Preheat Q & & No & $500.0^{n}$ \\
\hline 43 & SPRDSHT-1 & Spreadsheet & & & No & 500.0 * \\
\hline 44 & PSA Calcs & Spreadsheet & & & No & 500.0 * \\
\hline 45 & Water Pumn & Pump & 13 & 14 & & \\
\hline 46 & Water Pump & Pump & Water Pump Pwr & & No & $500.0 *$ \\
\hline 47 & & & 1 & Hydrogen & & \\
\hline 48 & PSA & Component Splitter & PSA Power & Purge gas & No & 500.0 * \\
\hline 49 & & & PSA heat & & & \\
\hline 50 & SET-1 & Set & & & No & $500.0 *$ \\
\hline 51 & ADJ-1 & Adjust & & & No & 3500 * \\
\hline 52 & & & & & & \\
\hline 53 & & & & & & \\
\hline $\begin{array}{ll}54 \\
55\end{array}$ & & & & & & \\
\hline 56 & & & & & & \\
\hline 57 & & & & & & \\
\hline $\begin{array}{l}58 \\
59\end{array}$ & & & & & & \\
\hline 60 & & & & & & \\
\hline \begin{tabular}{l|}
61 \\
62
\end{tabular} & & & & & & \\
\hline 63 & Honeywell International Ir & & niSim Design (R400 & ld 16067) & & Page 5 of 7 \\
\hline
\end{tabular}




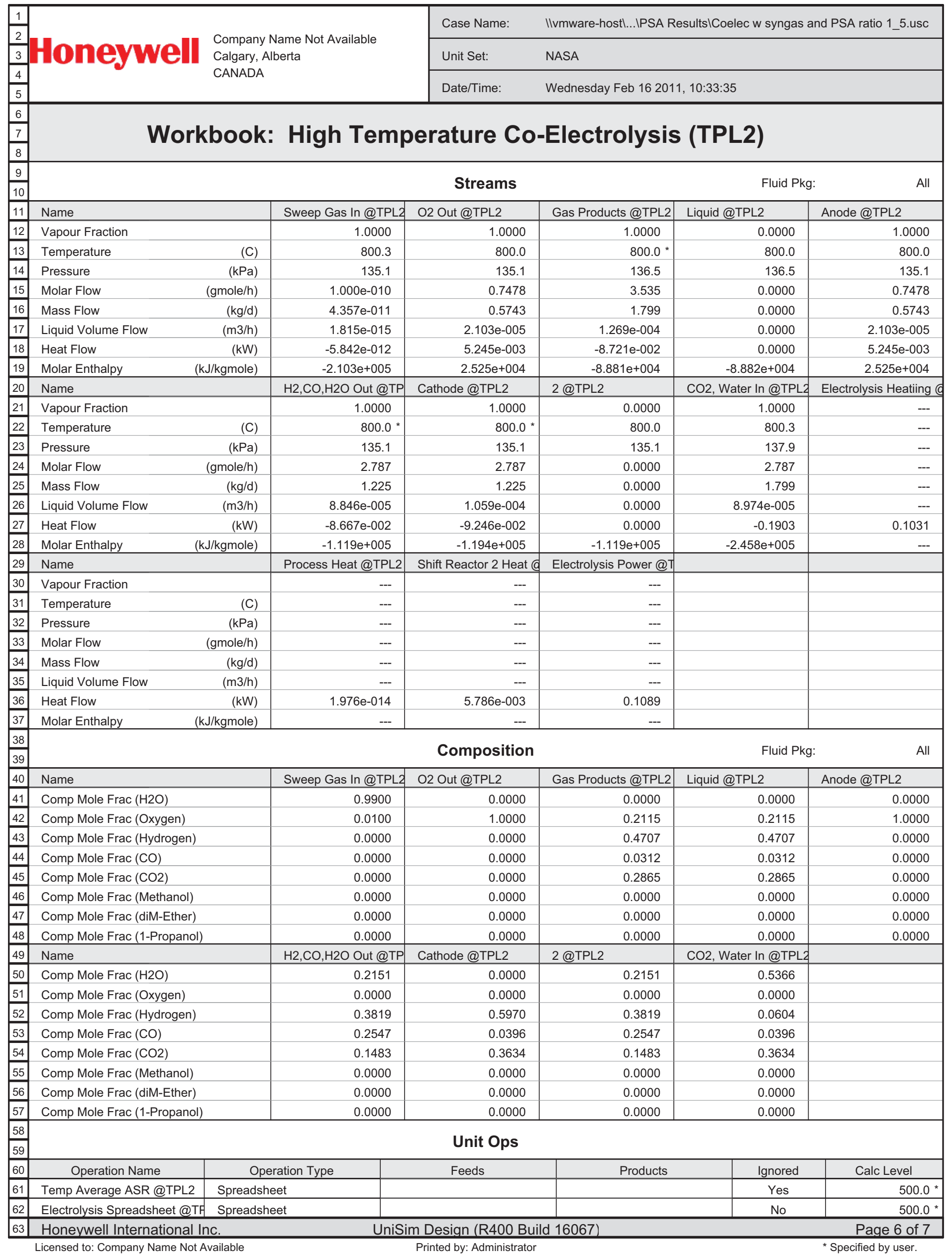




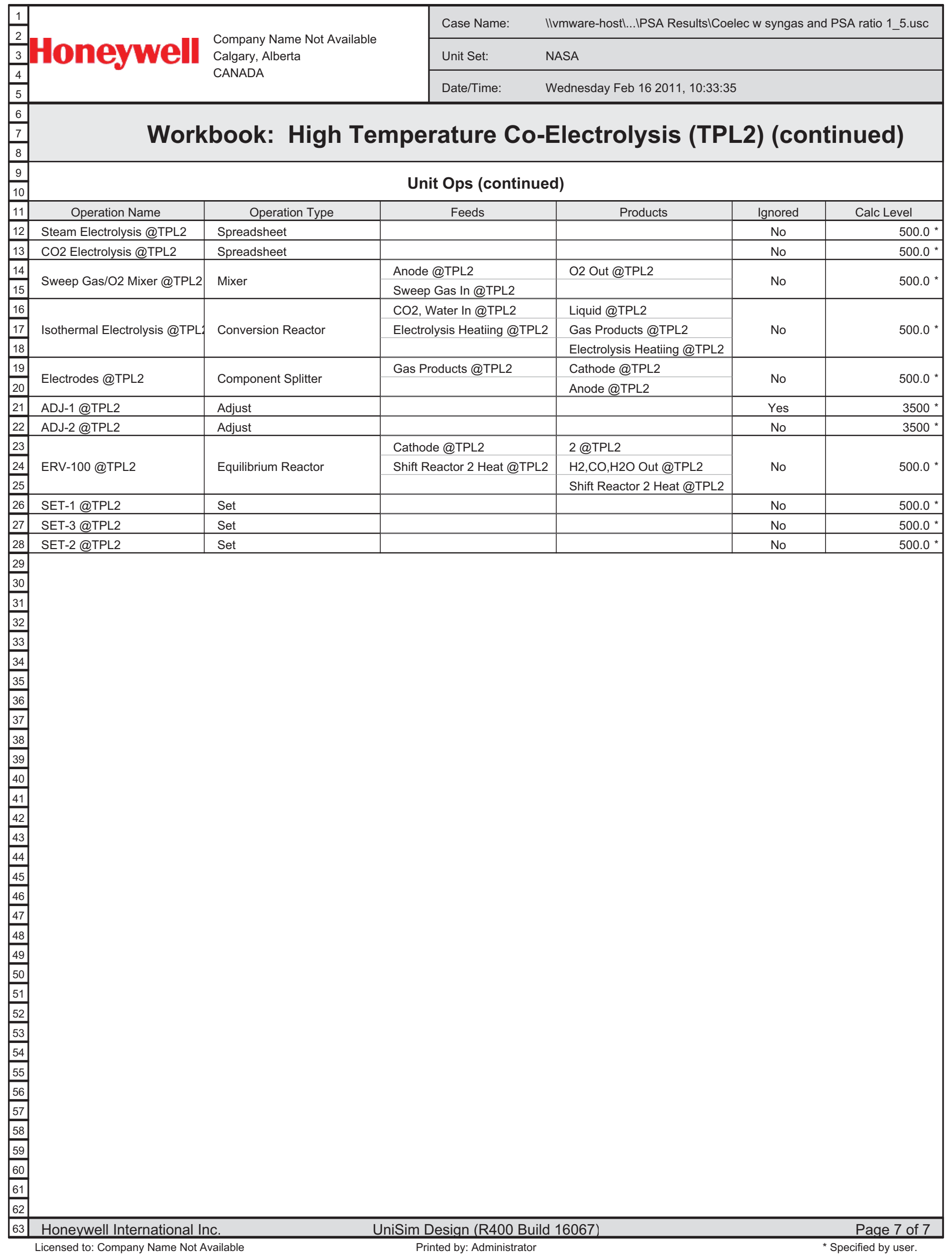




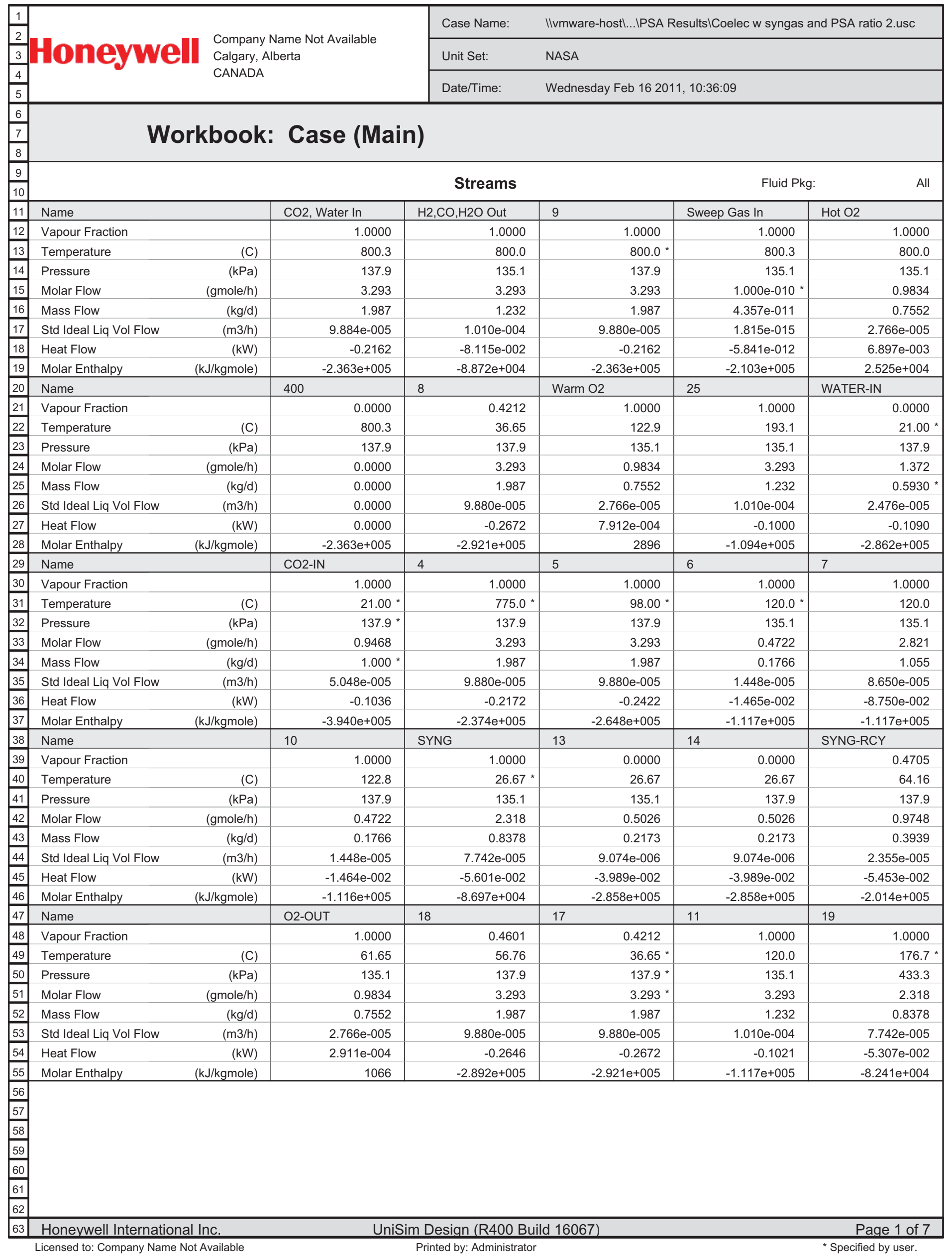




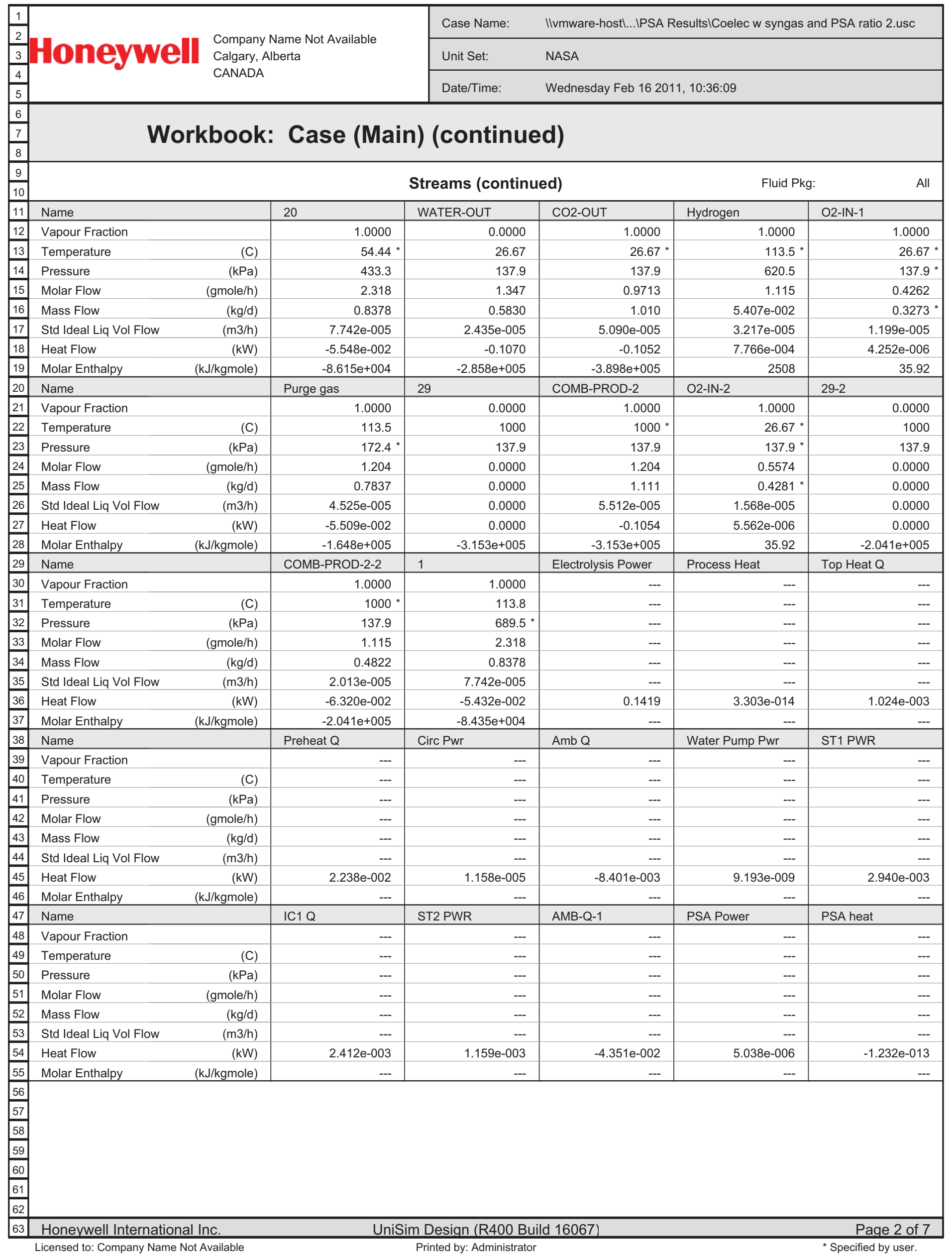




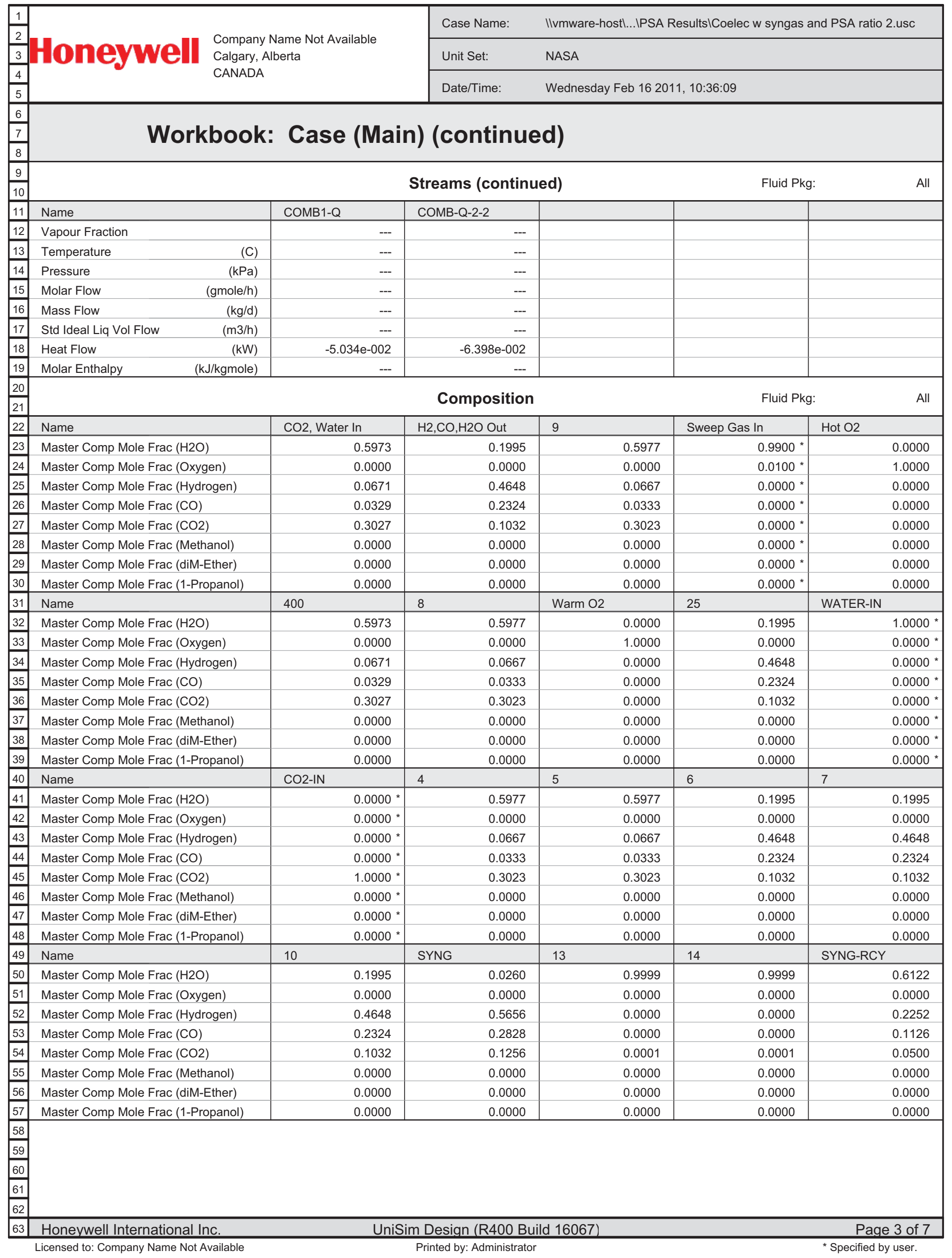




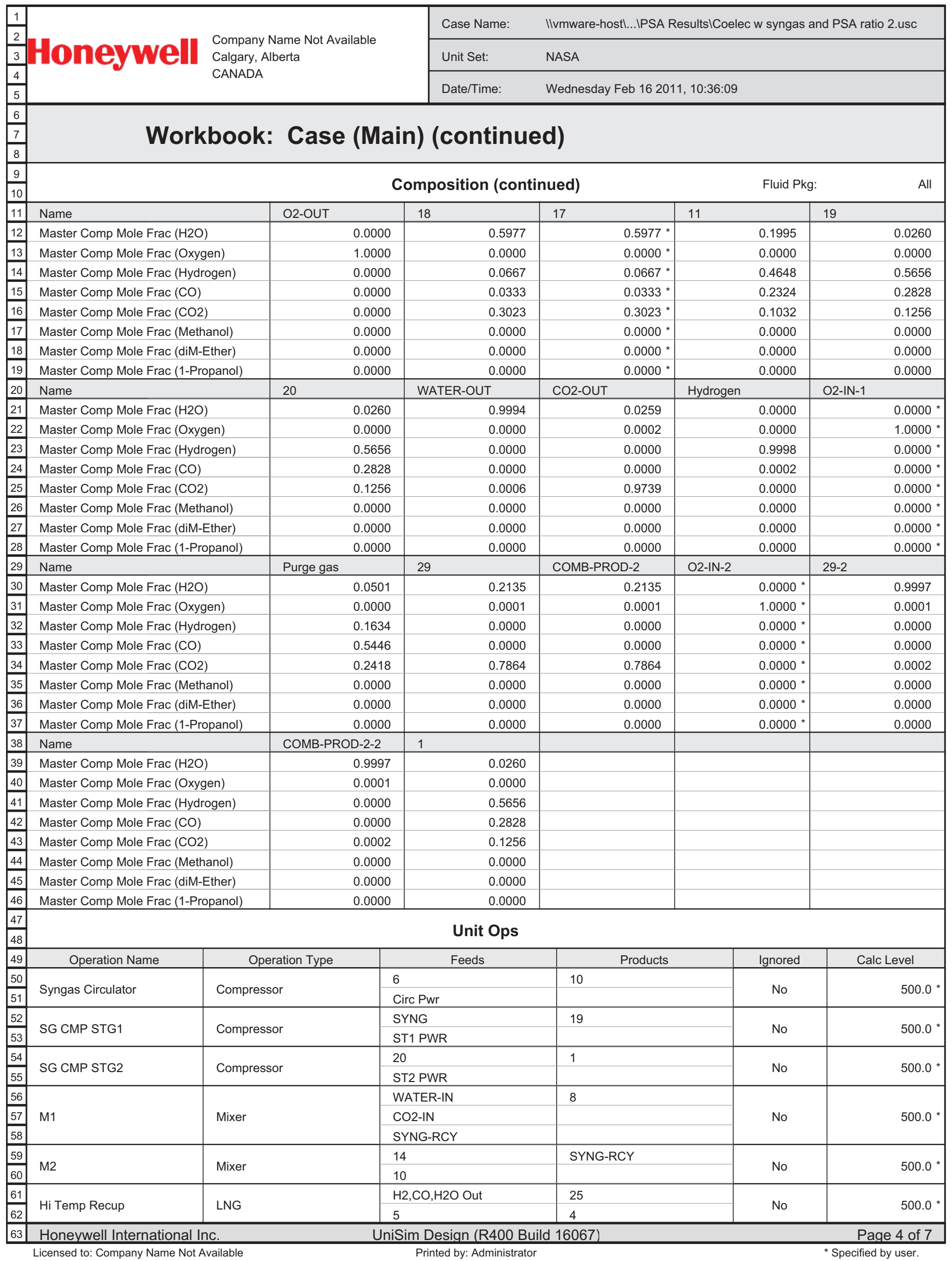




\begin{tabular}{|c|c|c|c|c|c|c|}
\hline \multirow{2}{*}{\begin{tabular}{|l|}
1 \\
2 \\
3
\end{tabular}} & \multirow{3}{*}{$\begin{array}{l}\text { Company Name Not Available } \\
\text { Calgary, Alberta } \\
\text { CANADA }\end{array}$} & \multirow{3}{*}{$\begin{array}{l}\text { Company Name Not Available } \\
\text { Calgary, Alberta } \\
\text { CANADA }\end{array}$} & Case Name: & \\
\hline & & & Unit Set: & \multicolumn{3}{|c|}{ IIvmware-host|...IPSA ResultsICoelec w syngas and PSA ratio 2.usc } \\
\hline$\frac{4}{5}$ & & & Date/Time: & \multicolumn{3}{|c|}{ Wednesday Feb 16 2011, 10:36:09 } \\
\hline$\frac{6}{7}$ & \multicolumn{6}{|c|}{ Workbook: Case (Main) (continued) } \\
\hline$\frac{9}{10}$ & \multicolumn{6}{|c|}{ Unit Ops (continued) } \\
\hline 11 & Operation Name & Operation Type & Feeds & Products & Ignored & Calc Level \\
\hline 12 & Hi Temp Recup & LNG & $\mathrm{Hot} \mathrm{O} 2$ & Warm O2 & No & $500.0^{*}$ \\
\hline 13 & \multirow{3}{*}{ Lo Temp Recup } & \multirow{3}{*}{ LNG } & 25 & 11 & \multirow{3}{*}{ No } & \multirow{3}{*}{$500.0 *$} \\
\hline 14 & & & 17 & 18 & & \\
\hline 15 & & & Warm O2 & O2-OUT & & \\
\hline 16 & \multirow{2}{*}{ RWGS 1} & \multirow{2}{*}{ Equilibrium Reactor } & 9 & 400 & \multirow{2}{*}{ No } & \multirow{2}{*}{$500.0 *$} \\
\hline 17 & & & & $\mathrm{CO} 2$, Water In & & \\
\hline 18 & \multirow{3}{*}{ COMBUSTOR 1} & & $\mathrm{O} 2-\mathrm{IN}-1$ & 29 & & \\
\hline 19 & & Conversion Reactor & Purge gas & COMB-PROD-2 & No & $500.0 *$ \\
\hline 20 & & & COMB1-Q & COMB1-Q & & \\
\hline 21 & & & $\mathrm{O} 2-\mathrm{IN}-2$ & $29-2$ & & \\
\hline 22 & COMBUSTOR 2 & Conversion Reactor & Hydrogen & COMB-PROD-2-2 & No & 500.0 * \\
\hline 23 & & & COMB-Q-2-2 & COMB-Q-2-2 & & \\
\hline 24 & & & 7 & 13 & & \\
\hline 25 & Water Knockout Tank & Separator & $A m b$ Q & SYNG & No & 500.0 * \\
\hline 26 & & & & $\mathrm{Amb} \mathrm{Q}$ & & \\
\hline 27 & & & COMB-PROD-2 & WATER-OUT & & \\
\hline 28 & KO-DRM 2 & Separator & COMB-PROD-2-2 & CO2-OUT & No & $500.0 *$ \\
\hline 29 & & & AMB-Q-1 & AMB-Q-1 & & \\
\hline 30 & & & 19 & 20 & & \\
\hline 31 & INI CLR 1 & Cooler & & $\mathrm{IC} 1 \mathrm{Q}$ & No & $500.0 *$ \\
\hline 32 & $\mathrm{RCY}-4$ & Recycle & 8 & 17 & No & 3500 * \\
\hline 33 & & & 11 & 6 & & $5000 *$ \\
\hline 34 & 11 & lee & & 7 & No & 500.0 \\
\hline 35 & & & Sweep Gas In & Hot O2 & & \\
\hline 36 & & & CO2, Water In & $\mathrm{H} 2, \mathrm{CO}, \mathrm{H} 2 \mathrm{O}$ Out & $\mathrm{Ne}$ & $2500 *$ \\
\hline 37 & High I emperature Co-Electrol & Standard Sub-Flowsheet & Process Heat & & No & $2500=$ \\
\hline 38 & & & Electrolysis Power & & & \\
\hline 39 & Topning Heat & Heater & 4 & 9 & & $5000 *$ \\
\hline 40 & Iopping Heat & Heater & Top Heat Q & & No & $500.0=$ \\
\hline 41 & Preheater & & 18 & 5 & & $5000 *$ \\
\hline 42 & Preheater & Heater & Preheat Q & & No & $500.0=$ \\
\hline 43 & SPRDSHT-1 & Spreadsheet & & & No & $500.0 *$ \\
\hline 44 & PSA Calcs & Spreadsheet & & & No & $500.0^{*}$ \\
\hline 45 & Water Pumn & Pumn & 13 & 14 & & $5000 *$ \\
\hline 46 & Water Pump & Pump & Water Pump Pwr & & No & $500.0 *$ \\
\hline 47 & & & 1 & Hydrogen & & \\
\hline 48 & PSA & Component Splitter & PSA Power & Purge gas & No & 500.0 * \\
\hline 49 & & & PSA heat & & & \\
\hline 50 & SET-1 & Set & & & No & $500.0^{*}$ \\
\hline 51 & ADJ-1 & Adjust & & & No & 3500 * \\
\hline 52 & & & & & & \\
\hline 53 & & & & & & \\
\hline $\begin{array}{l}54 \\
55\end{array}$ & & & & & & \\
\hline 56 & & & & & & \\
\hline 57 & & & & & & \\
\hline 58 & & & & & & \\
\hline 60 & & & & & & \\
\hline \begin{tabular}{|l|l|}
62 \\
62 \\
\end{tabular} & & & & & & \\
\hline 63 & Honeywell International In & & niSim Design (R400 & (d 16067) & & Page 5 of 7 \\
\hline
\end{tabular}




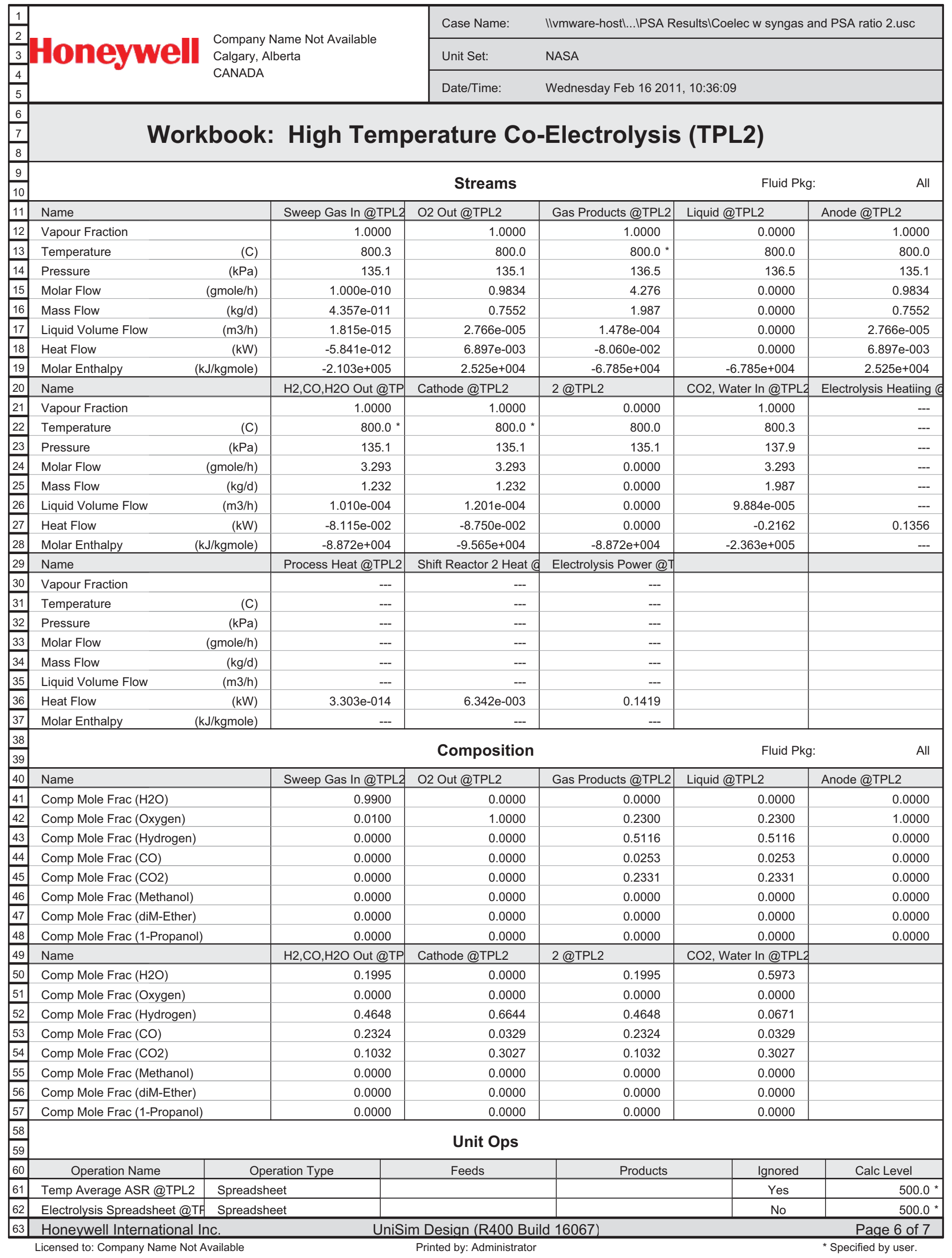




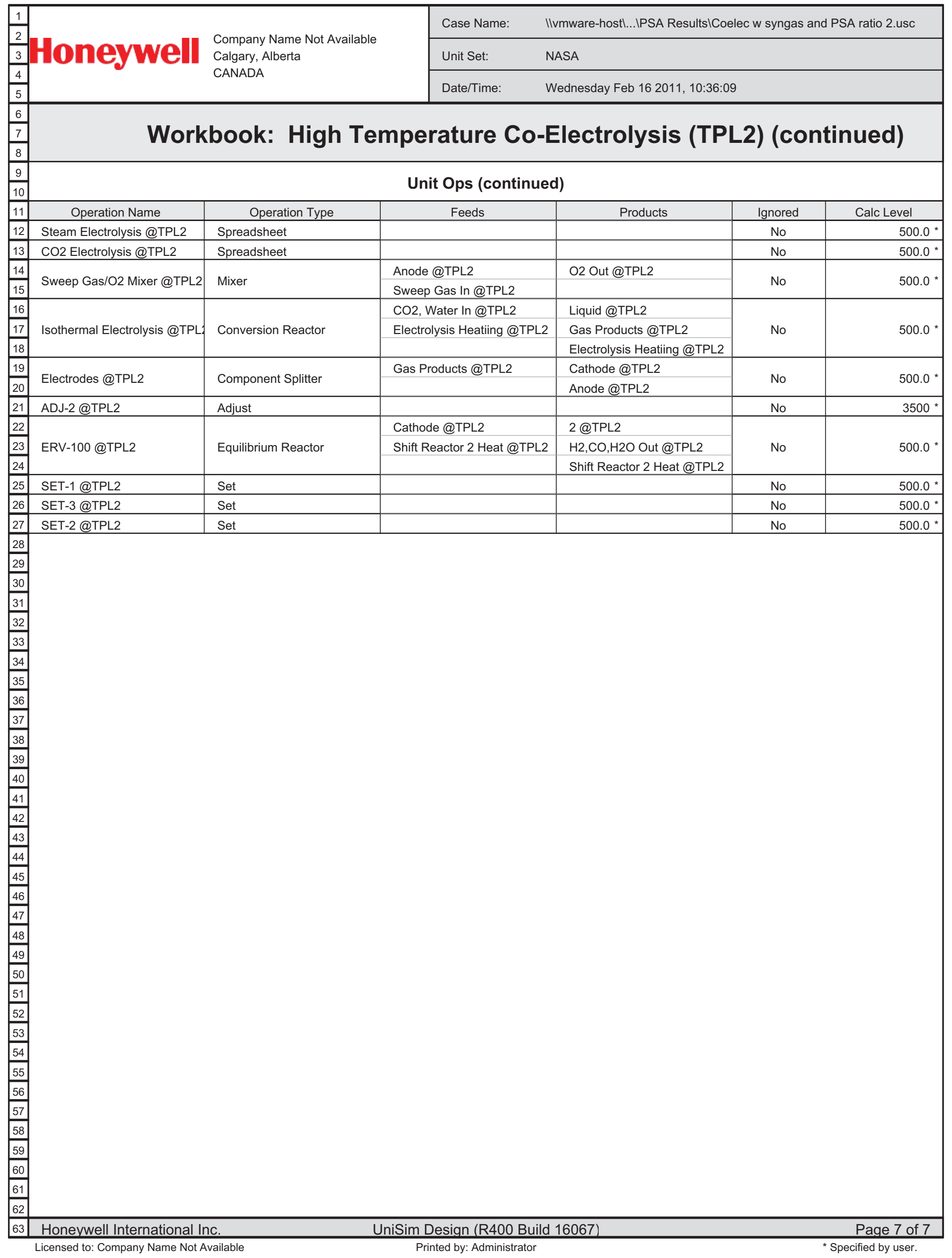




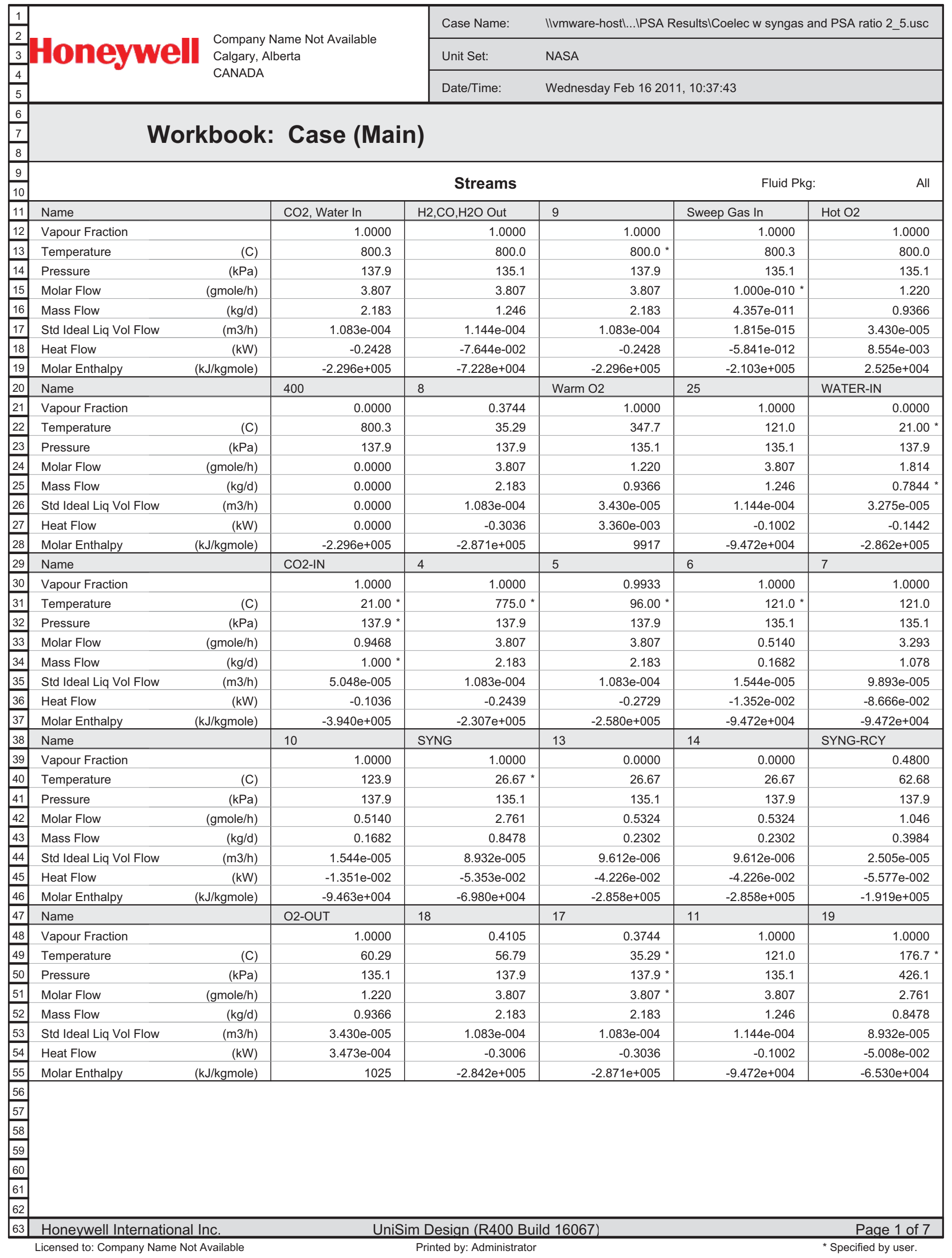




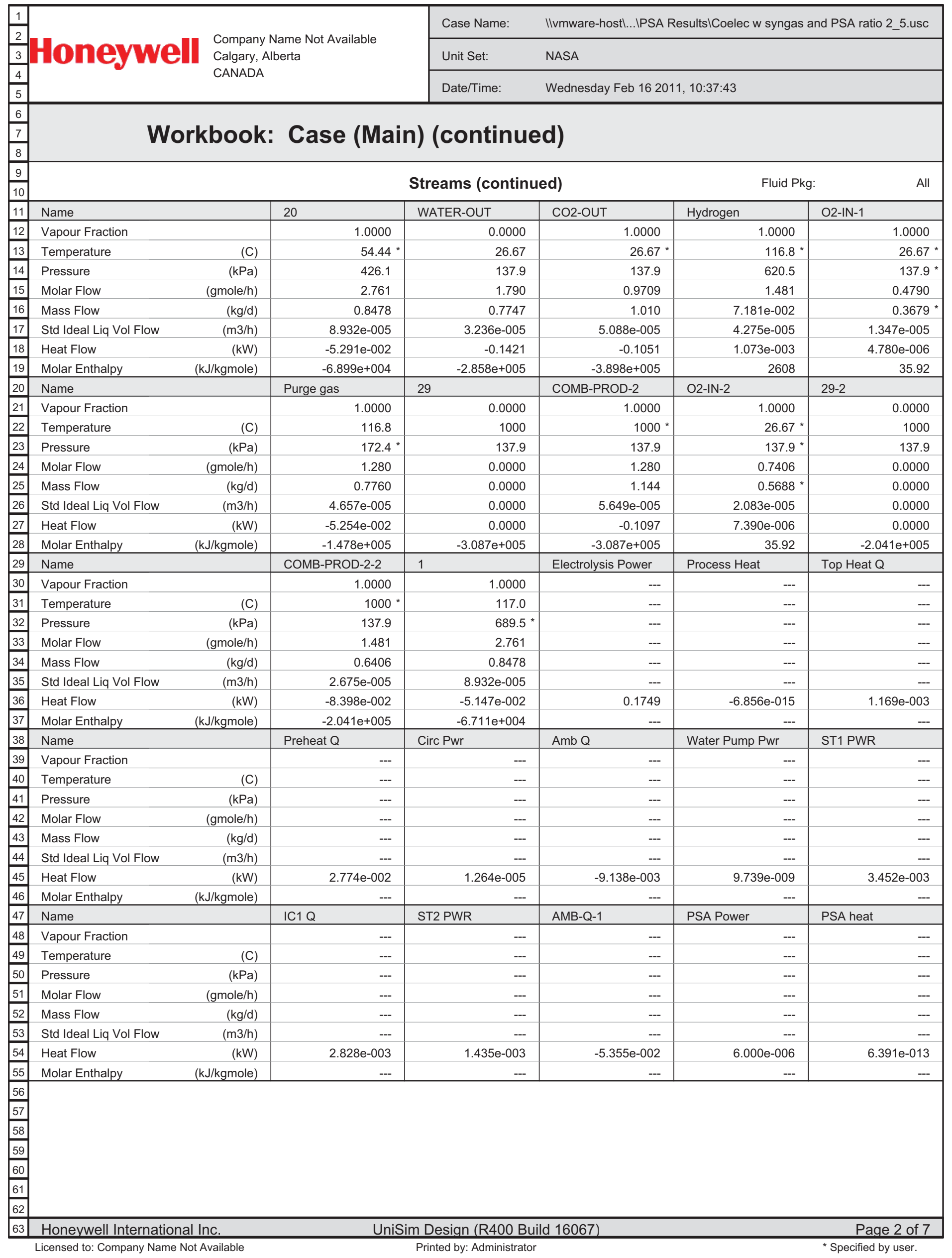




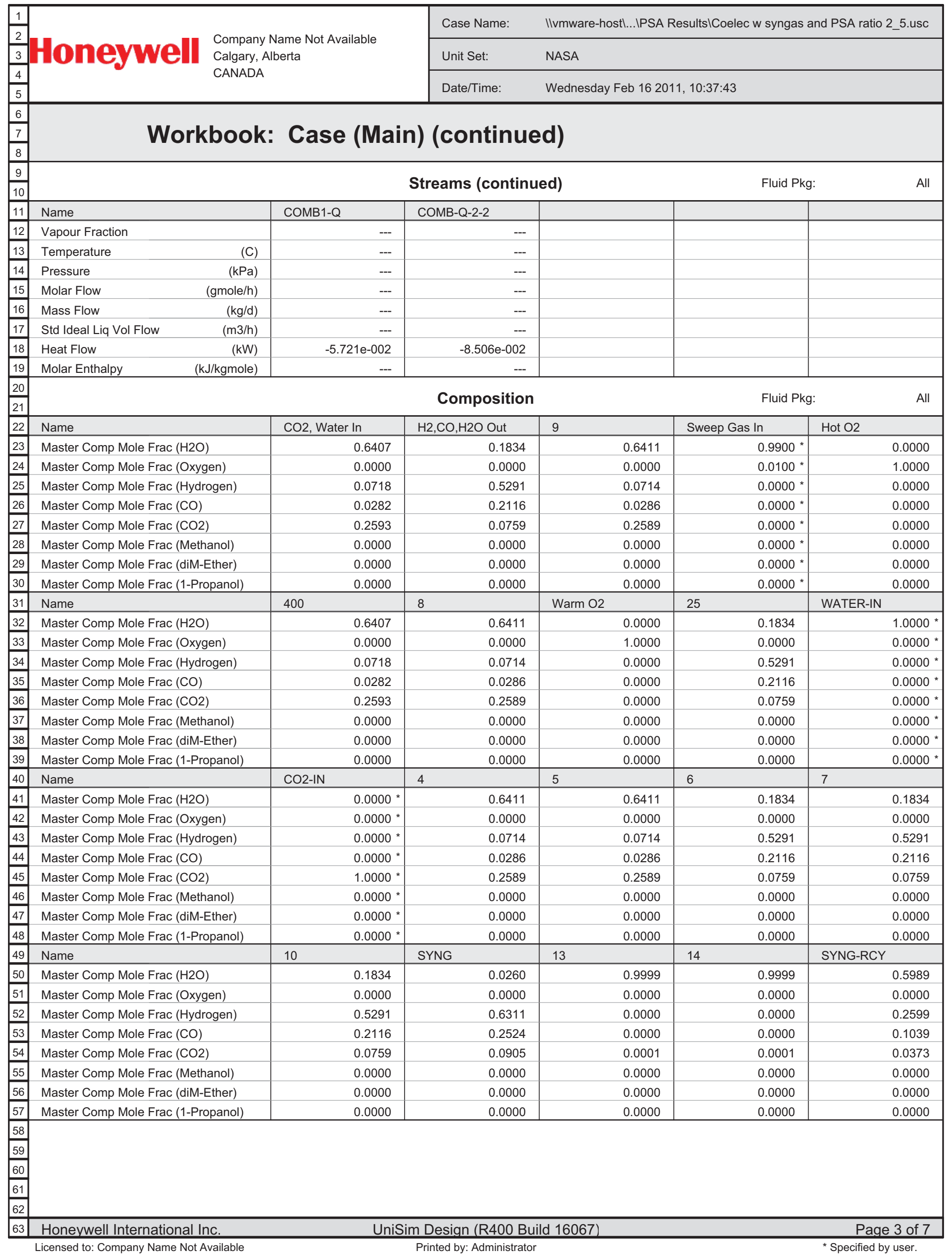




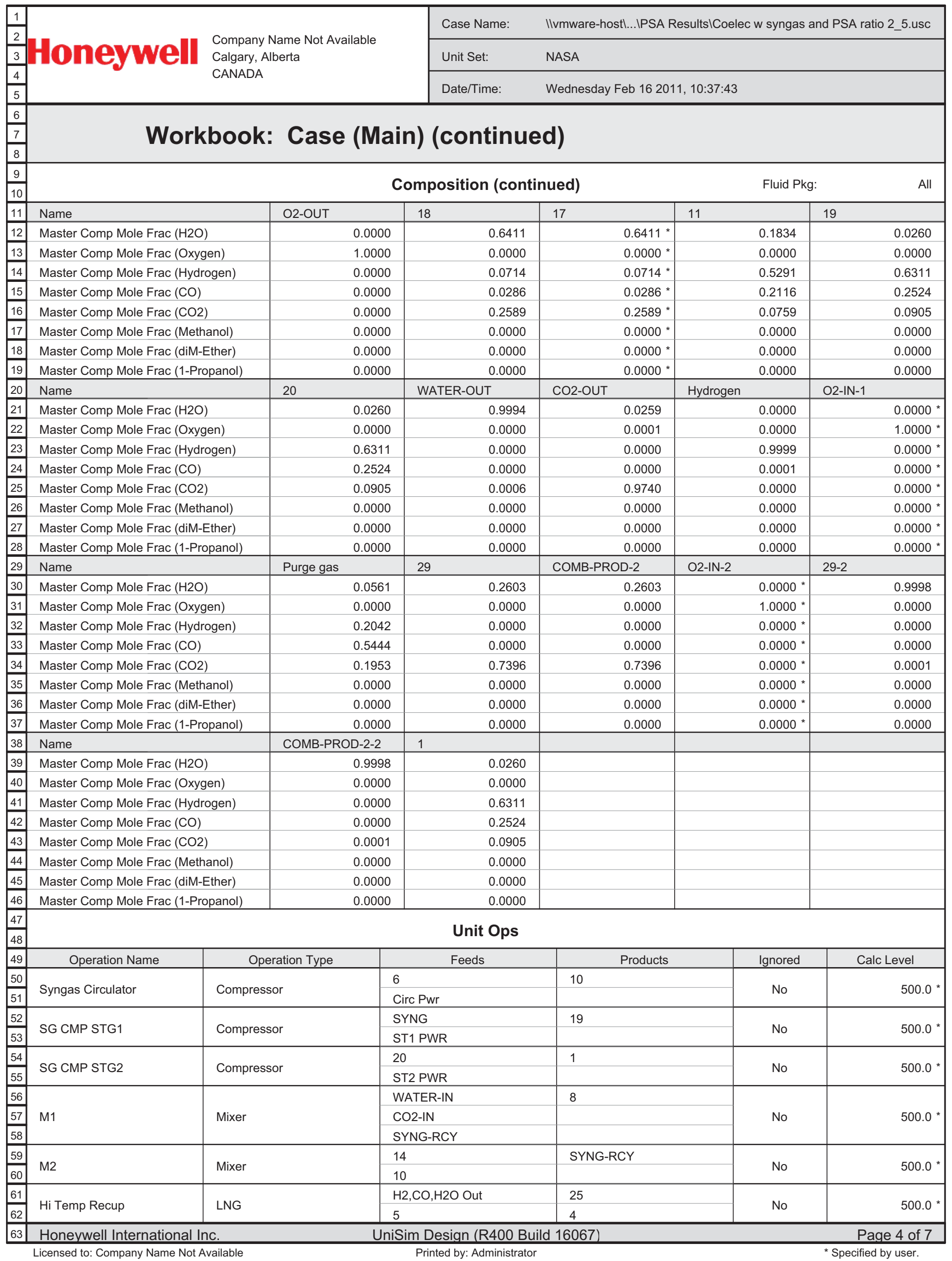




\begin{tabular}{|c|c|c|c|c|c|c|}
\hline 1 & & & Case Name: & |lvmware-hostl...IPSA & w syngas & A ratio 2_5.usc \\
\hline 3 & Honey & Calgary, Alberta & Unit Set: & NASA & & \\
\hline$\frac{4}{5}$ & & UATVAL & Date/Time: & Wednesday Feb 1620 & & \\
\hline$\frac{6}{\frac{7}{8}}$ & Work & book: Case (N & ain) (contin & d) & & \\
\hline$\frac{9}{10}$ & & & Unit Ops (con & ed) & & \\
\hline 11 & Operation Name & Operation Type & Feeds & Products & Ignored & Calc Level \\
\hline 12 & Hi Temp Recup & LNG & Hot O2 & Warm O2 & No & $500.0^{*}$ \\
\hline 13 & & & 25 & 11 & & \\
\hline 14 & Lo Temp Recup & LNG & 17 & 18 & No & $500.0 *$ \\
\hline 15 & & & Warm O2 & O2-OUT & & \\
\hline 16 & RWGS 1 & Fquilibrium Reactor & 9 & 400 & $\mathrm{No}$ & 5000 * $>2 \div<\geqslant$ \\
\hline 17 & RVVGS I & Equmingum Reacior & & $\mathrm{CO} 2$, Water In & INO & 500.0 \\
\hline 18 & & & O2-IN-1 & 29 & & \\
\hline 19 & COMBUSTOR 1 & Conversion Reactor & Purge gas & COMB-PROD-2 & No & $500.0 *$ \\
\hline 20 & & & COMB1-Q & COMB1-Q & & \\
\hline 21 & & & O2-IN-2 & $29-2$ & & \\
\hline 22 & COMBUSTOR 2 & Conversion Reactor & Hydrogen & COMB-PROD-2-2 & No & 500.0 * \\
\hline 23 & & & COMB-Q-2-2 & COMB-Q-2-2 & & \\
\hline 24 & & & 7 & 13 & & \\
\hline 25 & Water Knockout Tank & Separator & $A m b$ Q & SYNG & No & $500.0 *$ \\
\hline 26 & & & & Amb Q & & \\
\hline 27 & & & COMB-PROD-2 & WATER-OUT & & \\
\hline 28 & KO-DRM 2 & Separator & COMB-PROD-2-2 & CO2-OUT & No & $500.0 *$ \\
\hline 29 & & & AMB-Q-1 & AMB-Q-1 & & \\
\hline 30 & INTT $C \mid \mathrm{R} 1$ & 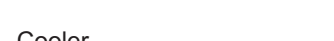 & 19 & 20 & $\mathrm{Ne}$ & $5000 *$ \\
\hline 31 & INI CLR I & Cooler & & IC1 Q & INO & 500.0 \\
\hline 32 & $\mathrm{RCY}-4$ & Recycle & 8 & 17 & No & 3500 * \\
\hline 33 & & & 11 & 6 & & 5000 * $>2>0$ \\
\hline 34 & 17 & lee & & 7 & No & 500.0 \\
\hline 35 & & & Sweep Gas In & Hot O2 & & \\
\hline 36 & Hiah Temnerature Co-Flectrol & Standard Suh_Flowsheet & $\mathrm{CO} 2$, Water In & $\mathrm{H} 2, \mathrm{CO}, \mathrm{H} 2 \mathrm{O}$ Out & $\mathrm{No}$ & $2500 *$ \\
\hline 37 & 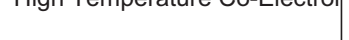 & 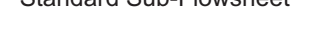 & Process Heat & & TNo & 2000 \\
\hline 38 & & & Electrolysis Power & & & \\
\hline 39 & Tonning Heat & Heater & 4 & 9 & & $5000 *$ \\
\hline 40 & loppıng Heat & Heater & Top Heat Q & & No & 500.0 \\
\hline 41 & Preheater & Heater & 18 & 5 & & 5000 * $>2>0$ \\
\hline 42 & Preheater & Heater & Preheat Q & & No & 500.0 \\
\hline 43 & SPRDSHT-1 & Spreadsheet & & & No & $500.0 *$ \\
\hline 44 & PSA Calcs & Spreadsheet & & & No & $500.0^{*}$ \\
\hline 45 & Water Pumn & Pump & 13 & 14 & & $5000 *$ \\
\hline 46 & Water Pump & Pump & Water Pump Pwr & & No & 500.0 \\
\hline 47 & & & 1 & Hydrogen & & \\
\hline 48 & PSA & Component Splitter & PSA Power & Purge gas & No & 500.0 * \\
\hline 49 & & & PSA heat & & & \\
\hline 50 & SET-1 & Set & & & No & $500.0 *$ \\
\hline 51 & ADJ-1 & Adjust & & & No & 3500 * \\
\hline 52 & ADJ-2 & Adjust & & & Yes & 3500 * \\
\hline 53 & & & & & & \\
\hline 54 & & & & & & \\
\hline$\frac{55}{56}$ & & & & & & \\
\hline 57 & & & & & & \\
\hline 58 & & & & & & \\
\hline 59 & & & & & & \\
\hline$\frac{60}{61}$ & & & & & & \\
\hline 62 & & & & & & \\
\hline 63 & Honeywell International In & & niSim Design (R400 & d 16067) & & Page 5 of 7 \\
\hline
\end{tabular}




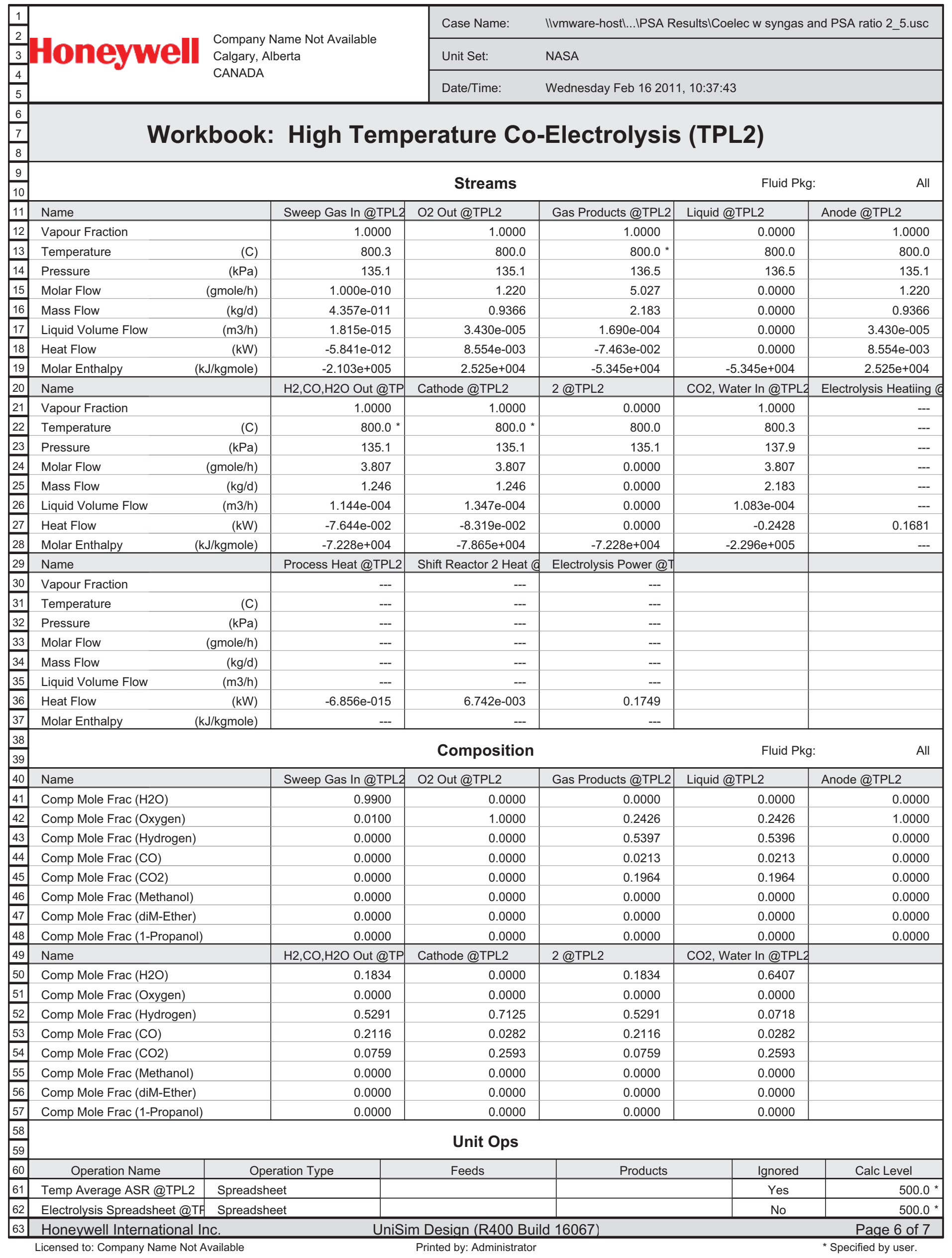




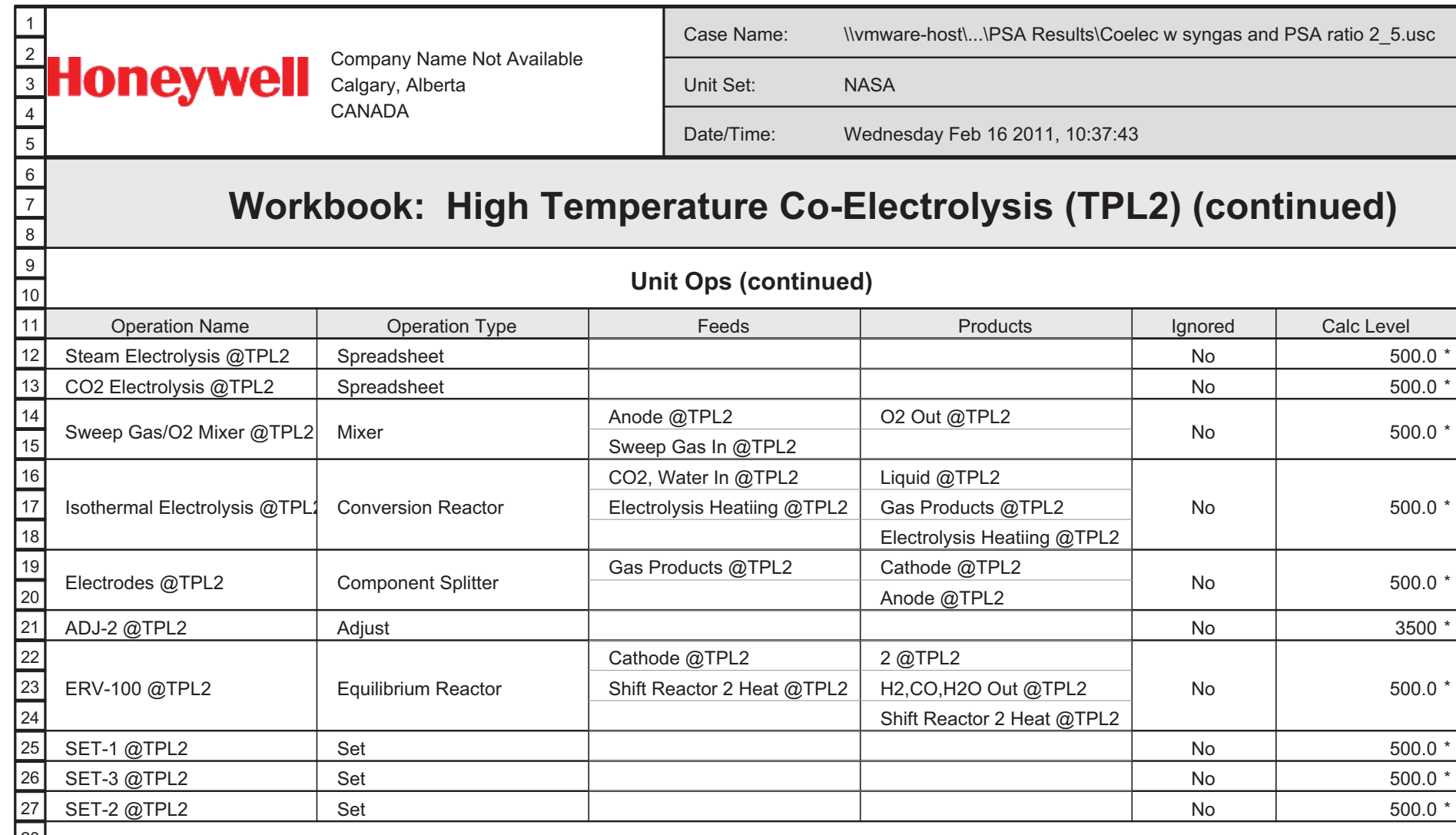

\begin{tabular}{|l|}
\hline 29 \\
\hline 30 \\
\hline 32 \\
\hline 33 \\
\hline 34 \\
\hline 35 \\
\hline 36 \\
\hline 37 \\
\hline 38 \\
\hline 39 \\
\hline 40 \\
\hline 41 \\
\hline 42 \\
\hline 43 \\
\hline 44 \\
\hline 45 \\
\hline 46 \\
\hline 47 \\
\hline 48 \\
\hline 49 \\
\hline 50 \\
\hline 51 \\
\hline 52 \\
\hline 53 \\
\hline 54 \\
\hline 55 \\
\hline 56 \\
\hline 57 \\
\hline 58 \\
\hline 59 \\
\hline 60 \\
\hline 61 \\
\hline 62 \\
\hline 63 \\
\hline
\end{tabular} 


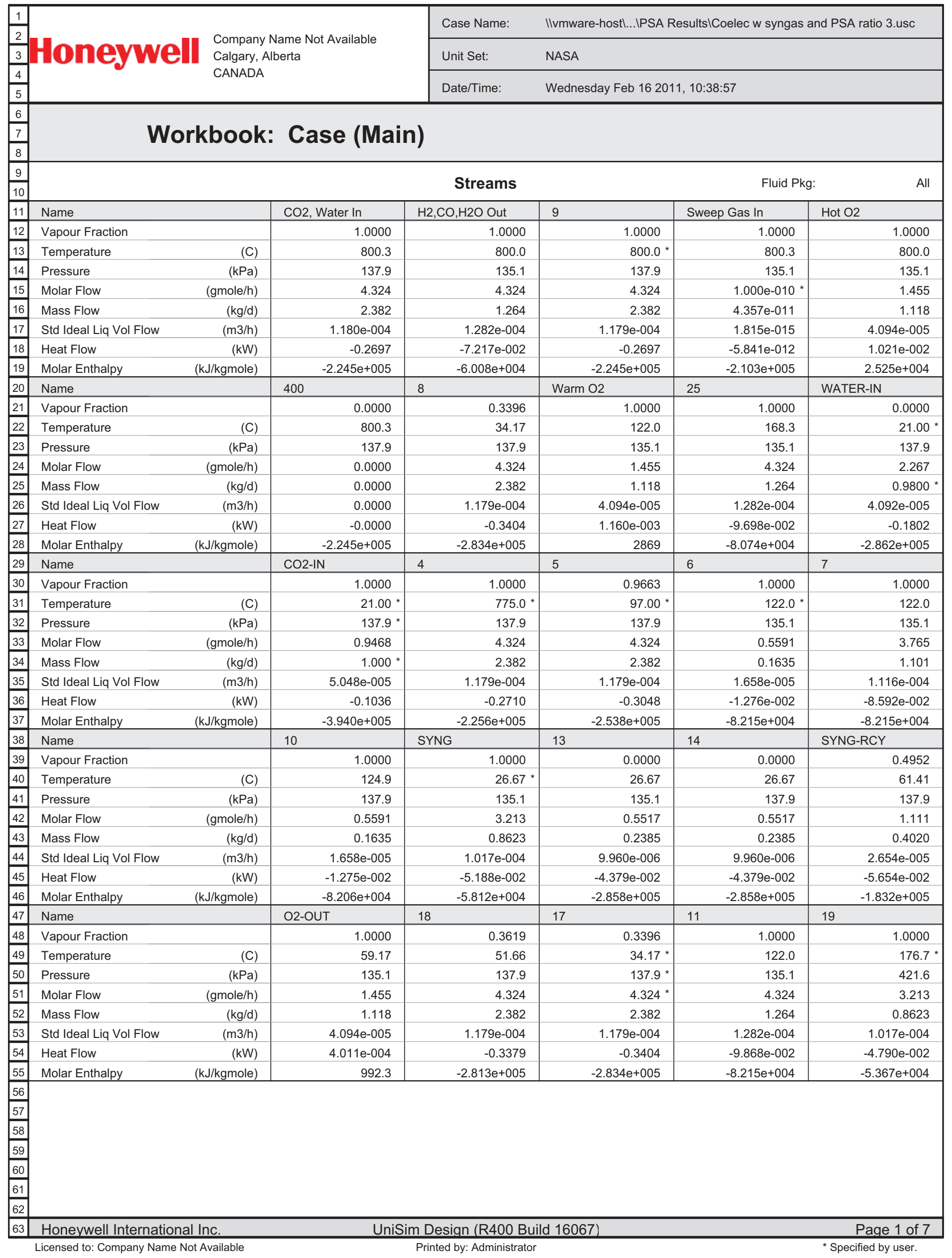




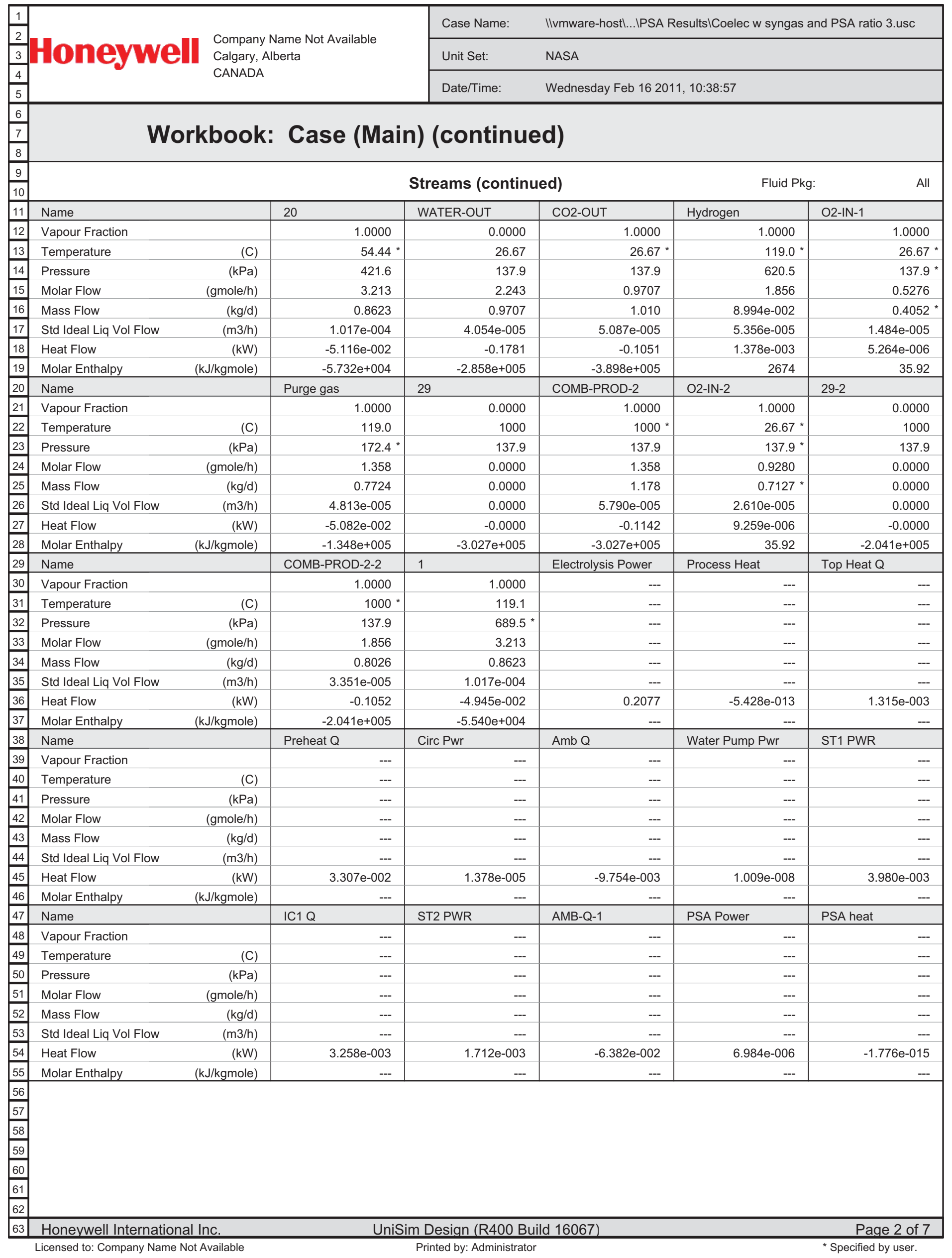




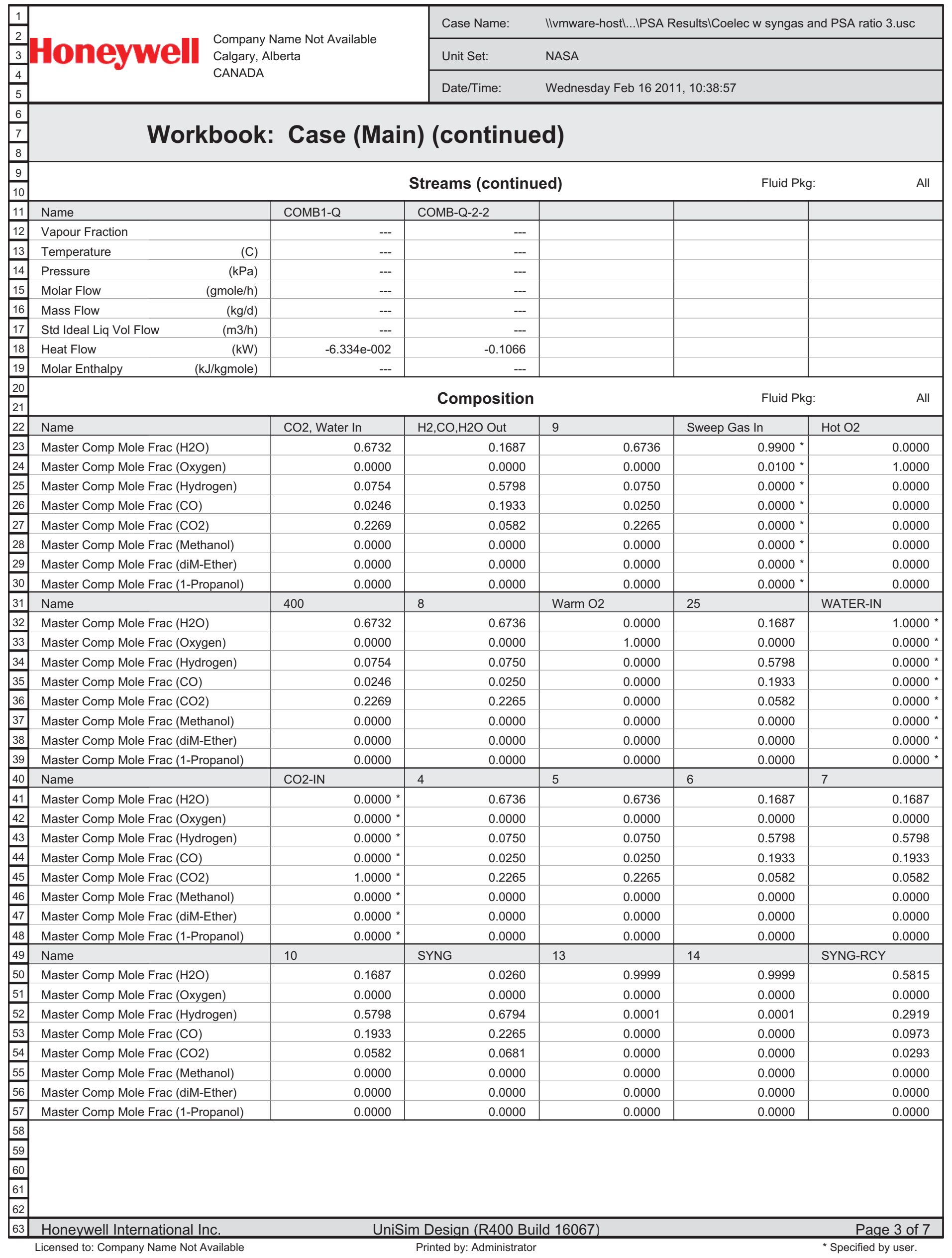




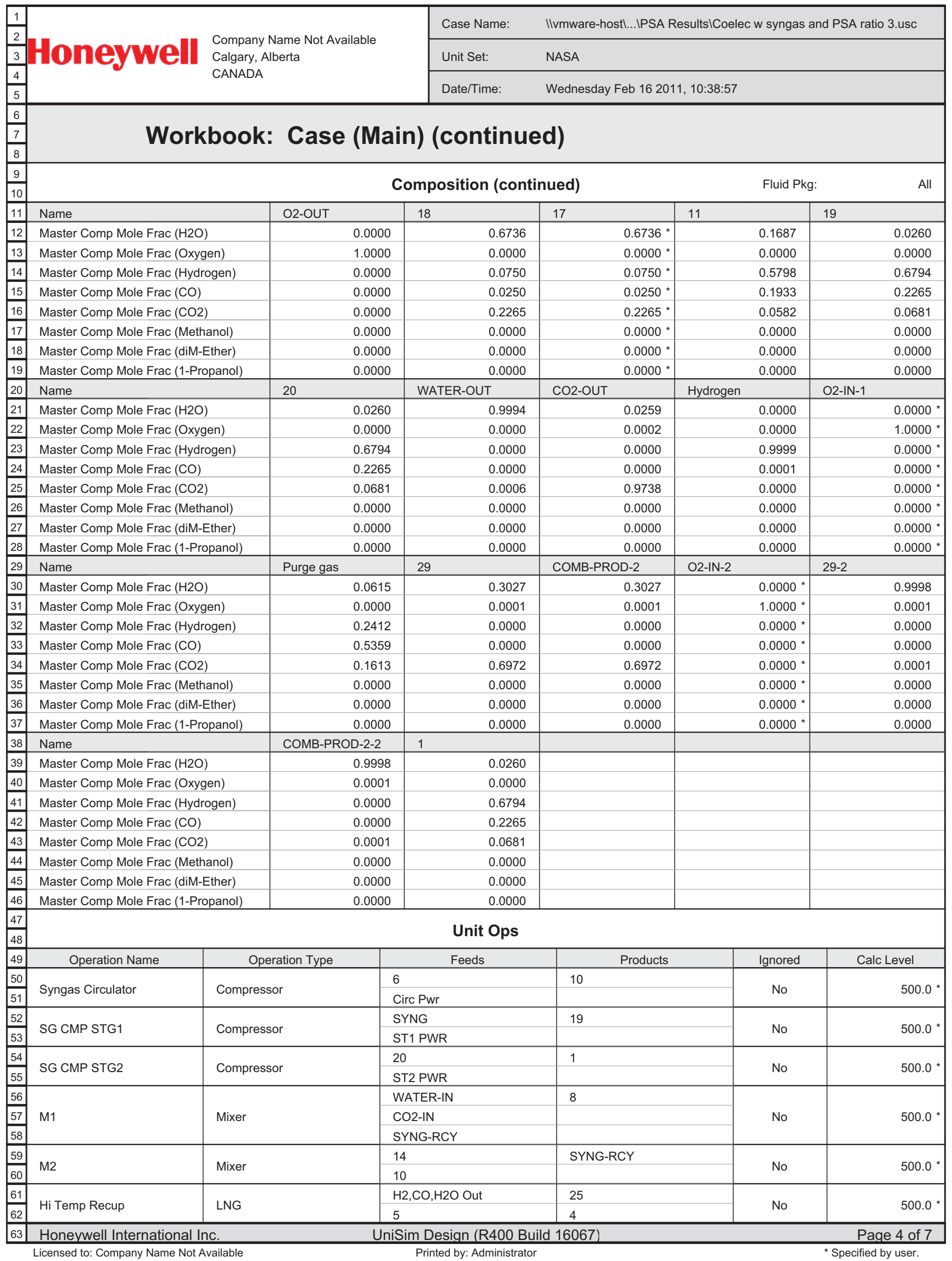




\begin{tabular}{|c|c|c|c|c|c|c|}
\hline \multirow{2}{*}{\begin{tabular}{|l|}
1 \\
2 \\
3 \\
\end{tabular}} & \multirow{3}{*}{$\begin{array}{l}\text { Company Name Not Available } \\
\text { Calgary, Alberta } \\
\text { CANADA }\end{array}$} & \multirow{3}{*}{$\begin{array}{l}\text { Company Name Not Availabl } \\
\text { Calgary, Alberta } \\
\text { CANADA }\end{array}$} & Case Name: & \\
\hline & & & Unit Set: & \multicolumn{3}{|c|}{ IIvmware-host|...IPSA ResultsICoelec w syngas and PSA ratio 3.usc } \\
\hline$\frac{4}{5}$ & & & Date/Time: & \multicolumn{3}{|c|}{ Wednesday Feb $162011,10: 38: 57$} \\
\hline$\frac{6}{7}$ & \multicolumn{6}{|c|}{ Workbook: Case (Main) (continued) } \\
\hline$\frac{9}{10}$ & \multicolumn{6}{|c|}{ Unit Ops (continued) } \\
\hline 11 & Operation Name & Operation Type & Feeds & Products & Ignored & Calc Level \\
\hline 12 & Hi Temp Recup & LNG & $\mathrm{Hot} \mathrm{O} 2$ & Warm O2 & No & $500.0^{*}$ \\
\hline 13 & \multirow{3}{*}{ Lo Temp Recup } & \multirow{3}{*}{ LNG } & 25 & 11 & \multirow{3}{*}{ No } & \multirow{3}{*}{$500.0 *$} \\
\hline 14 & & & 17 & 18 & & \\
\hline 15 & & & Warm O2 & O2-OUT & & \\
\hline 16 & \multirow{2}{*}{ RWGS 1} & \multirow{2}{*}{ Equilibrium Reactor } & 9 & 400 & \multirow{2}{*}{ No } & \multirow{2}{*}{$500.0 *$} \\
\hline 17 & & & & $\mathrm{CO} 2$, Water In & & \\
\hline 18 & \multirow{3}{*}{ COMBUSTOR 1} & & $\mathrm{O} 2-\mathrm{IN}-1$ & 29 & & \\
\hline 19 & & Conversion Reactor & Purge gas & COMB-PROD-2 & No & $500.0 *$ \\
\hline 20 & & & COMB1-Q & COMB1-Q & & \\
\hline 21 & & & $\mathrm{O} 2-\mathrm{IN}-2$ & $29-2$ & & \\
\hline 22 & COMBUSTOR 2 & Conversion Reactor & Hydrogen & COMB-PROD-2-2 & No & 500.0 * \\
\hline 23 & & & COMB-Q-2-2 & COMB-Q-2-2 & & \\
\hline 24 & & & 7 & 13 & & \\
\hline 25 & Water Knockout Tank & Separator & $A m b$ Q & SYNG & No & 500.0 * \\
\hline 26 & & & & $\mathrm{Amb} \mathrm{Q}$ & & \\
\hline 27 & & & COMB-PROD-2 & WATER-OUT & & \\
\hline 28 & KO-DRM 2 & Separator & COMB-PROD-2-2 & CO2-OUT & No & $500.0 *$ \\
\hline 29 & & & AMB-Q-1 & AMB-Q-1 & & \\
\hline 30 & & & 19 & 20 & & \\
\hline 31 & INI CLR 1 & Cooler & & $\mathrm{IC} 1 \mathrm{Q}$ & No & $500.0 *$ \\
\hline 32 & $\mathrm{RCY}-4$ & Recycle & 8 & 17 & No & 3500 * \\
\hline 33 & & & 11 & 6 & & $5000 *$ \\
\hline 34 & 11 & lee & & 7 & No & 500.0 \\
\hline 35 & & & Sweep Gas In & Hot O2 & & \\
\hline 36 & & & CO2, Water In & $\mathrm{H} 2, \mathrm{CO}, \mathrm{H} 2 \mathrm{O}$ Out & $\mathrm{Ne}$ & $2500 *$ \\
\hline 37 & High I emperature Co-Electrol & Standard Sub-Flowsheet & Process Heat & & NO & 2000 \\
\hline 38 & & & Electrolysis Power & & & \\
\hline 39 & Topning Heat & Heater & 4 & 9 & & $5000 *$ \\
\hline 40 & Iopping Heat & Heater & Top Heat Q & & No & $500.0=$ \\
\hline 41 & Preheater & & 18 & 5 & & $5000 *$ \\
\hline 42 & Preheater & Heater & Preheat Q & & No & $500.0=$ \\
\hline 43 & SPRDSHT-1 & Spreadsheet & & & No & 500.0 * \\
\hline 44 & PSA Calcs & Spreadsheet & & & No & $500.0^{*}$ \\
\hline 45 & Water Pumn & Pumn & 13 & 14 & & 500.0 * \\
\hline 46 & Water Pump & Pump & Water Pump Pwr & & No & $500.0 *$ \\
\hline 47 & & & 1 & Hydrogen & & \\
\hline 48 & PSA & Component Splitter & PSA Power & Purge gas & No & 500.0 * \\
\hline 49 & & & PSA heat & & & \\
\hline 50 & SET-1 & Set & & & No & $500.0^{*}$ \\
\hline 51 & ADJ-1 & Adjust & & & No & 3500 * \\
\hline 52 & ADJ-2 & Adjust & & & Yes & 3500 * \\
\hline 53 & & & & & & \\
\hline 54 & & & & & & \\
\hline$\frac{55}{56}$ & & & & & & \\
\hline 57 & & & & & & \\
\hline 58 & & & & & & \\
\hline 59 & & & & & & \\
\hline 60 & & & & & & \\
\hline 62 & & & & & & \\
\hline 63 & Honeywell International In & & niSim Design (R400 & (d 16067) & & Page 5 of 7 \\
\hline
\end{tabular}




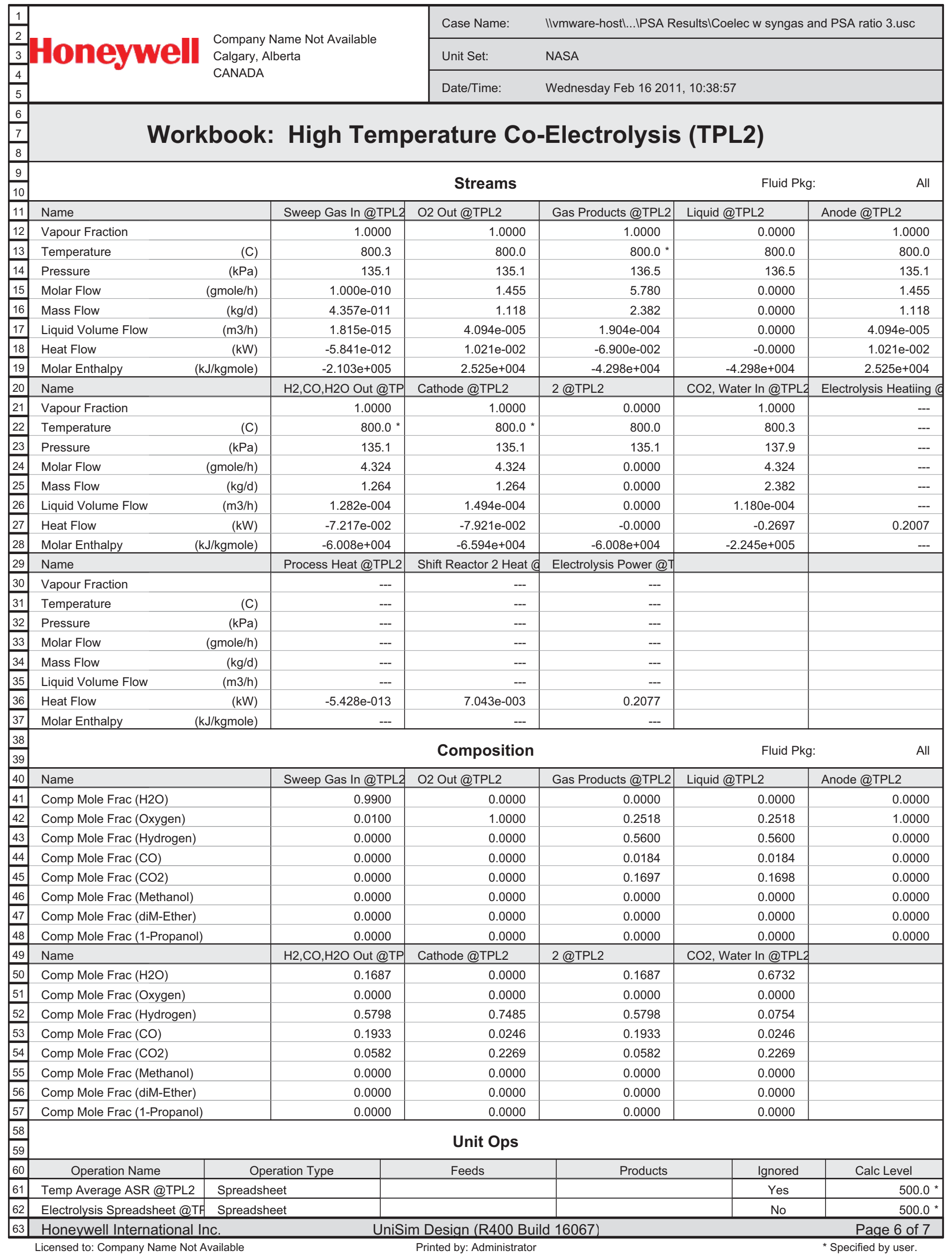




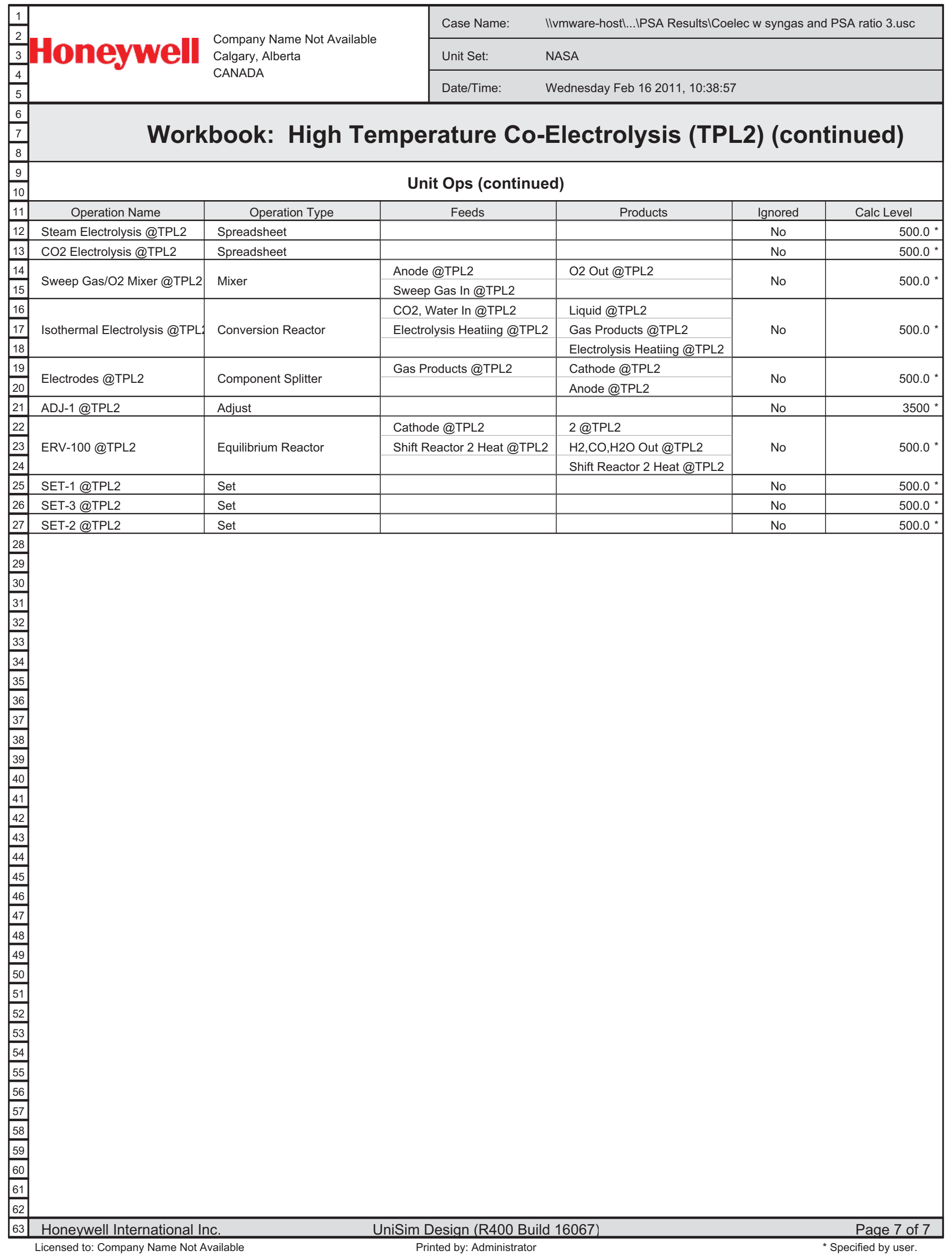




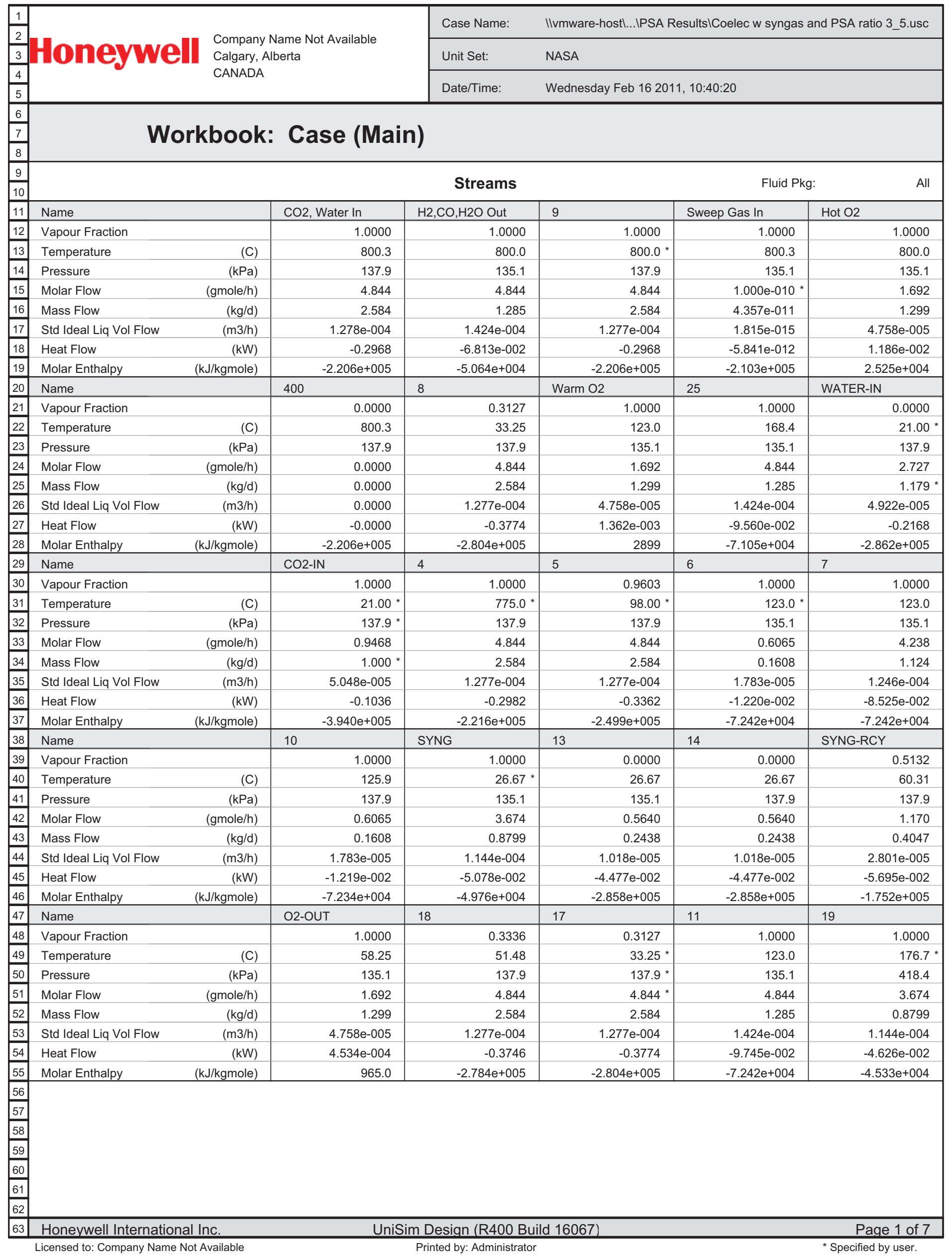




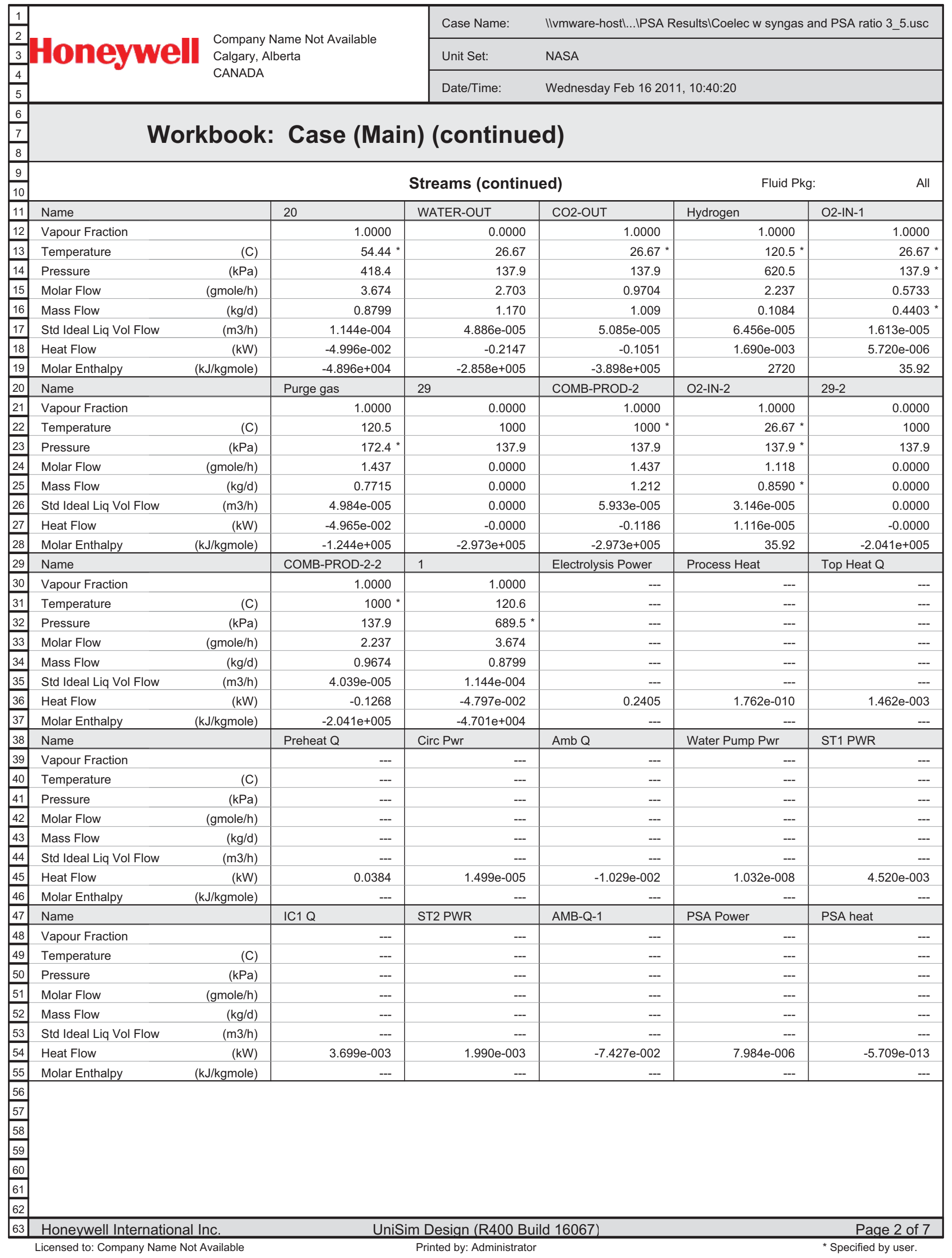




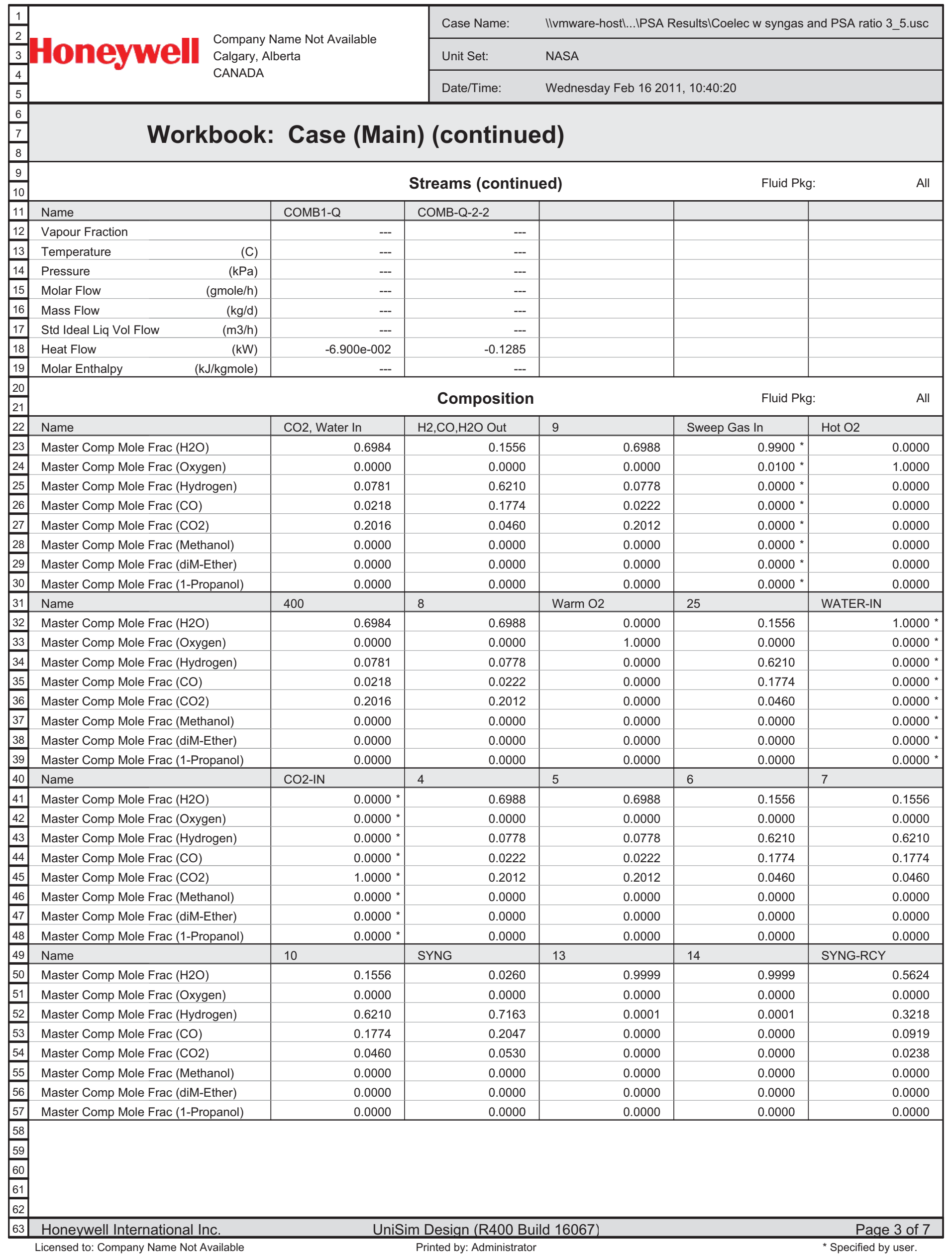




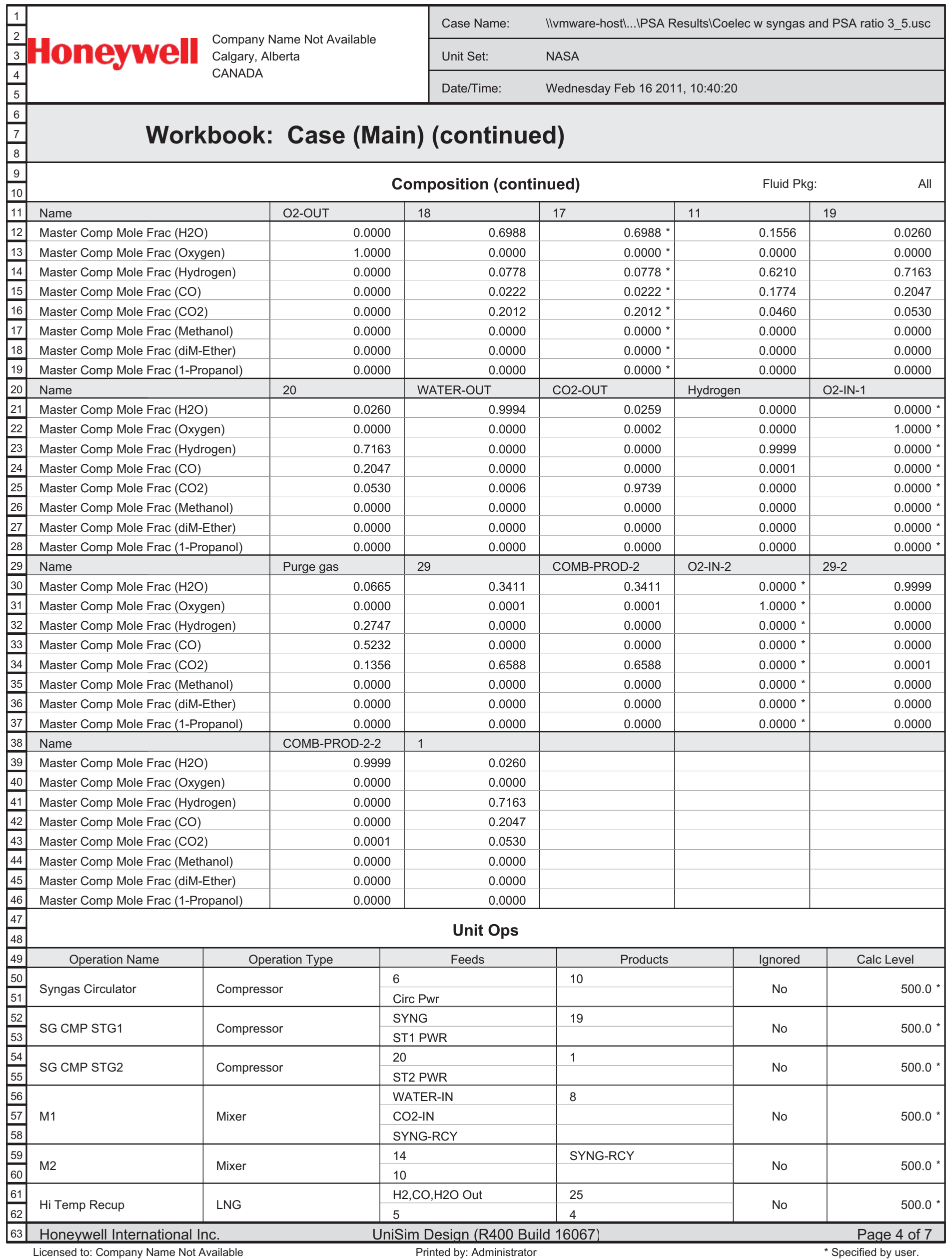




\begin{tabular}{|c|c|c|c|c|c|c|}
\hline 1 & & & Case Name: & |lvmware-hostl...IPSA & w syngas & A ratio 3_5.usc \\
\hline 3 & Honey & Calgary, Alberta & Unit Set: & NASA & & \\
\hline$\frac{4}{5}$ & & CHIVAD & Date/Time: & Wednesday Feb 1620 & & \\
\hline$\frac{6}{\frac{7}{8}}$ & Work & book: Case (N & ain) (contin & d) & & \\
\hline$\frac{9}{10}$ & & & Unit Ops (con & ed) & & \\
\hline 11 & Operation Name & Operation Type & Feeds & Products & Ignored & Calc Level \\
\hline 12 & Hi Temp Recup & LNG & Hot O2 & Warm O2 & No & $500.0^{*}$ \\
\hline 13 & & & 25 & 11 & & \\
\hline 14 & Lo Temp Recup & LNG & 17 & 18 & No & $500.0 *$ \\
\hline 15 & & & Warm O2 & O2-OUT & & \\
\hline 16 & RWGS 1 & Fquilibrium Reactor & 9 & 400 & $\mathrm{No}$ & 5000 * $>2 \div<\geqslant$ \\
\hline 17 & RVVGS I & Equmingum Reacior & & $\mathrm{CO} 2$, Water In & INO & 500.0 \\
\hline 18 & & & O2-IN-1 & 29 & & \\
\hline 19 & COMBUSTOR 1 & Conversion Reactor & Purge gas & COMB-PROD-2 & No & $500.0 *$ \\
\hline 20 & & & COMB1-Q & COMB1-Q & & \\
\hline 21 & & & O2-IN-2 & $29-2$ & & \\
\hline 22 & COMBUSTOR 2 & Conversion Reactor & Hydrogen & COMB-PROD-2-2 & No & 500.0 * \\
\hline 23 & & & COMB-Q-2-2 & COMB-Q-2-2 & & \\
\hline 24 & & & 7 & 13 & & \\
\hline 25 & Water Knockout Tank & Separator & $A m b$ Q & SYNG & No & $500.0 *$ \\
\hline 26 & & & & Amb Q & & \\
\hline 27 & & & COMB-PROD-2 & WATER-OUT & & \\
\hline 28 & KO-DRM 2 & Separator & COMB-PROD-2-2 & CO2-OUT & No & $500.0 *$ \\
\hline 29 & & & AMB-Q-1 & AMB-Q-1 & & \\
\hline 30 & INTT $C \mid \mathrm{R} 1$ & 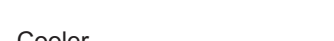 & 19 & 20 & $\mathrm{Ne}$ & $5000 *$ \\
\hline 31 & INI CLR I & Cooler & & IC1 Q & INO & 500.0 \\
\hline 32 & $\mathrm{RCY}-4$ & Recycle & 8 & 17 & No & 3500 * \\
\hline 33 & & & 11 & 6 & & 5000 * $>2>0$ \\
\hline 34 & 17 & lee & & 7 & No & 500.0 \\
\hline 35 & & & Sweep Gas In & Hot O2 & & \\
\hline 36 & Hiah Temnerature Co-Flectrol & Standard Suh_Flowsheet & $\mathrm{CO} 2$, Water In & $\mathrm{H} 2, \mathrm{CO}, \mathrm{H} 2 \mathrm{O}$ Out & $\mathrm{No}$ & $2500 *$ \\
\hline 37 & 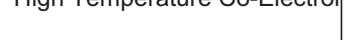 & 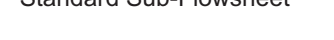 & Process Heat & & TNo & 2000 \\
\hline 38 & & & Electrolysis Power & & & \\
\hline 39 & Tonning Heat & Heater & 4 & 9 & & $5000 *$ \\
\hline 40 & loppıng Heat & Heater & Top Heat Q & & No & 500.0 \\
\hline 41 & Preheater & Heater & 18 & 5 & & 5000 * $>2>0$ \\
\hline 42 & Preheater & Heater & Preheat Q & & No & 500.0 \\
\hline 43 & SPRDSHT-1 & Spreadsheet & & & No & $500.0 *$ \\
\hline 44 & PSA Calcs & Spreadsheet & & & No & $500.0^{*}$ \\
\hline 45 & Water Pumn & Pump & 13 & 14 & & $5000 *$ \\
\hline 46 & Water Pump & Pump & Water Pump Pwr & & No & 500.0 \\
\hline 47 & & & 1 & Hydrogen & & \\
\hline 48 & PSA & Component Splitter & PSA Power & Purge gas & No & 500.0 * \\
\hline 49 & & & PSA heat & & & \\
\hline 50 & SET-1 & Set & & & No & $500.0 *$ \\
\hline 51 & ADJ-1 & Adjust & & & No & 3500 * \\
\hline 52 & ADJ-2 & Adjust & & & Yes & 3500 * \\
\hline 53 & & & & & & \\
\hline 54 & & & & & & \\
\hline$\frac{55}{56}$ & & & & & & \\
\hline 57 & & & & & & \\
\hline 58 & & & & & & \\
\hline 59 & & & & & & \\
\hline$\frac{60}{61}$ & & & & & & \\
\hline 62 & & & & & & \\
\hline 63 & Honeywell International In & & niSim Design (R400 & d 16067) & & Page 5 of 7 \\
\hline
\end{tabular}




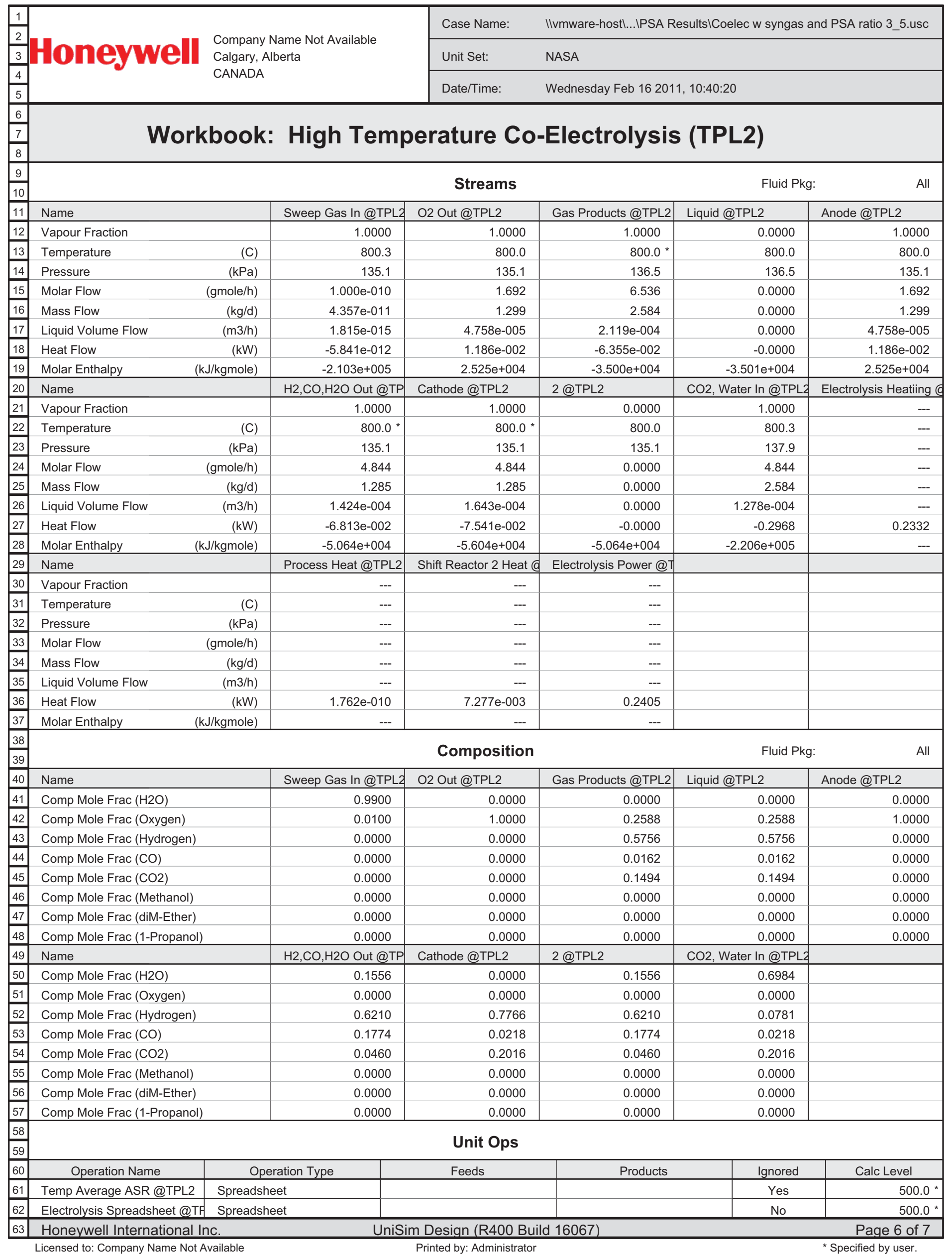




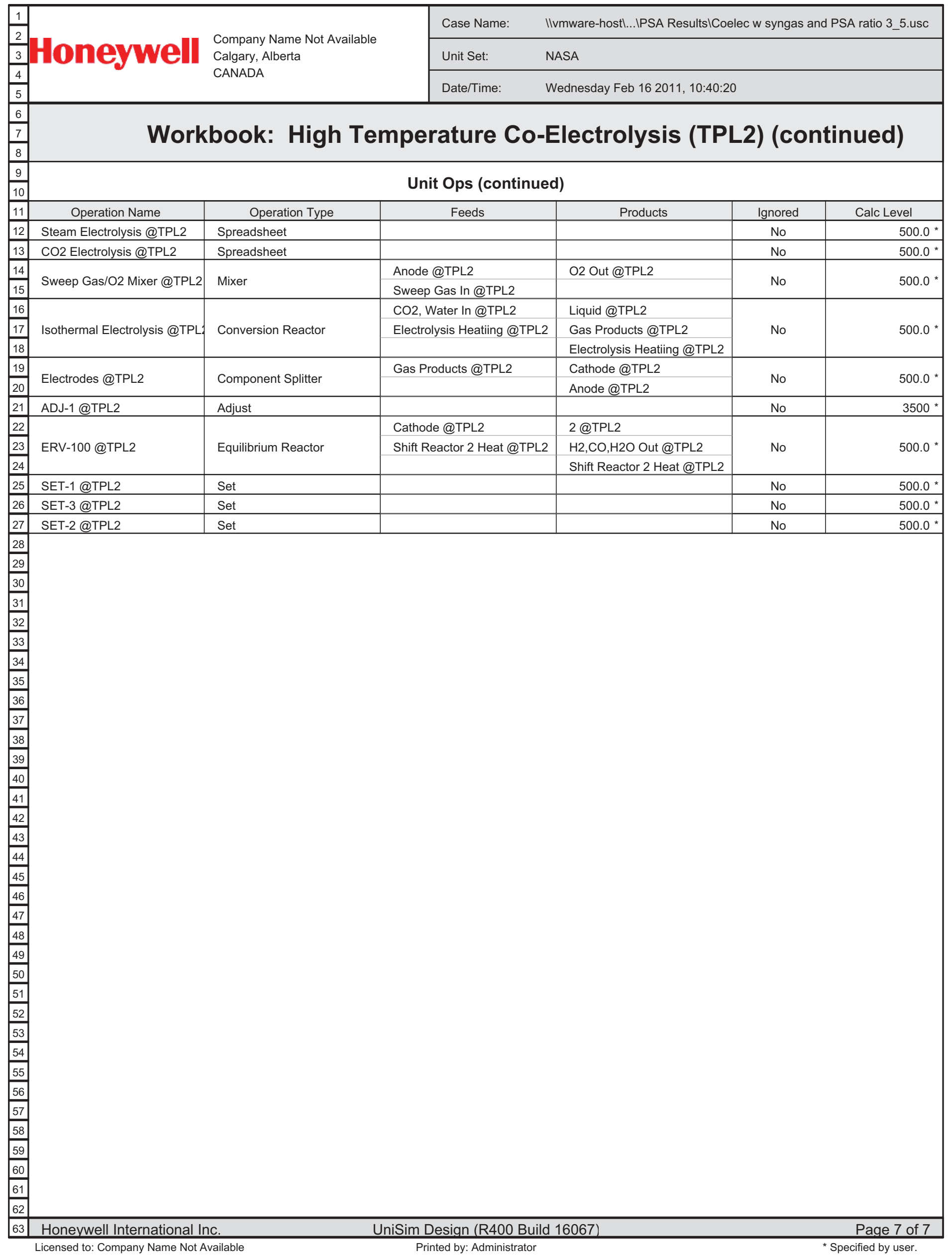




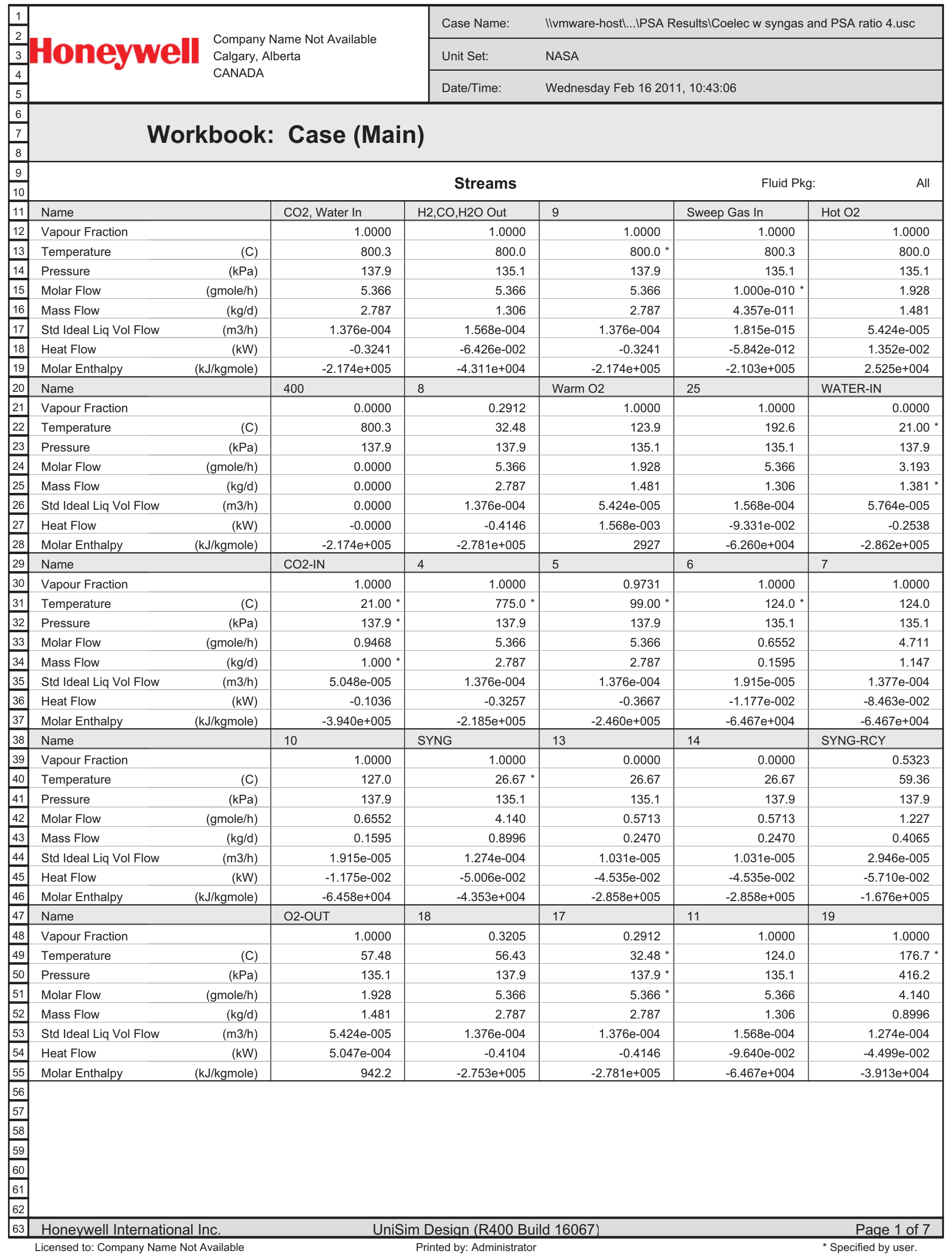




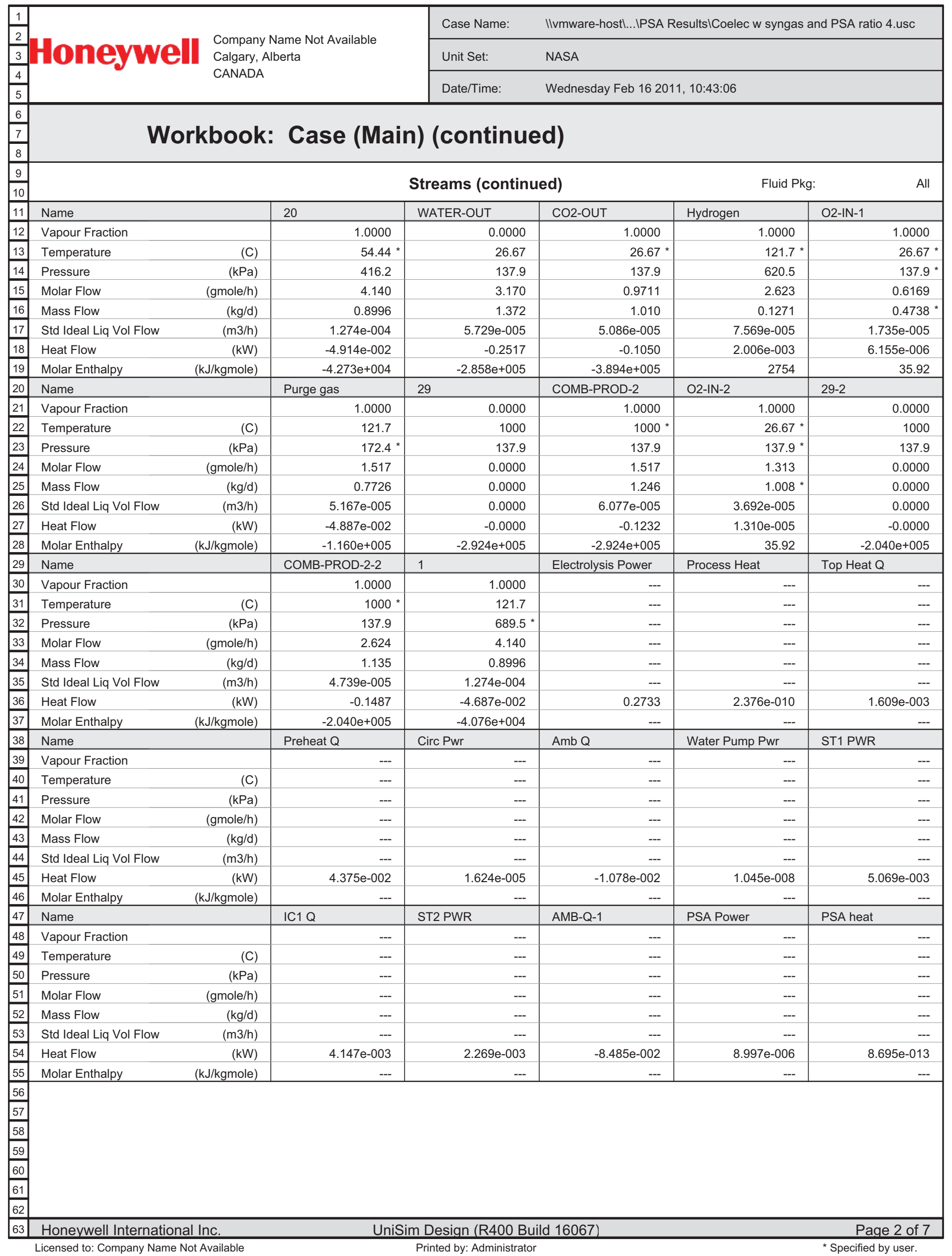




\begin{tabular}{|c|c|c|c|c|c|c|}
\hline 1 & \multirow{3}{*}{\multicolumn{2}{|c|}{$\begin{array}{l}\text { Company Name Not Available } \\
\text { Calgary, Alberta } \\
\text { CANADA }\end{array}$}} & \multirow{2}{*}{$\begin{array}{l}\text { Case Name: } \\
\text { Unit Set: }\end{array}$} & \multicolumn{3}{|c|}{ |lvmware-hostl...IPSA Results|Coelec w syngas and PSA ratio 4.usc } \\
\hline 3 & & & & \multicolumn{3}{|l|}{ NASA } \\
\hline$\frac{4}{5}$ & & & Date/Time: & \multicolumn{3}{|c|}{ Wednesday Feb 16 2011, 10:43:06 } \\
\hline$\frac{6}{7}$ & \multicolumn{6}{|c|}{ Workbook: Case (Main) (continued) } \\
\hline$\frac{9}{10}$ & \multicolumn{4}{|c|}{ Streams (continued) } & \multicolumn{2}{|c|}{ Fluid Pkg: } \\
\hline 11 & Name & COMB1-Q & COMB-Q-2-2 & & & \\
\hline 12 & Vapour Fraction & --- & --- & & & \\
\hline 13 & Temperature & --- & --- & & & \\
\hline 14 & Pressure & --- & --- & & & \\
\hline 15 & Molar Flow & --- & --- & & & \\
\hline 16 & Mass Flow & --- & --- & & & \\
\hline 17 & Std Ideal Liq Vol Flow & --- & --- & & & \\
\hline 18 & Heat Flow & $-7.433 e-002$ & -0.1507 & & & \\
\hline 19 & Molar Enthalpy & --- & --- & & & \\
\hline$\frac{20}{21}$ & \multicolumn{4}{|c|}{ Composition } & \multicolumn{2}{|c|}{ Fluid Pkg: } \\
\hline 22 & Name & $\mathrm{CO} 2$, Water In & $\mathrm{H} 2, \mathrm{CO}, \mathrm{H} 2 \mathrm{O}$ Out & 9 & Sweep Gas In & $\mathrm{Hot} \mathrm{O} 2$ \\
\hline 23 & Master Comp Mole Frac $(\mathrm{H} 2 \mathrm{O})$ & 0.7187 & 0.1441 & 0.7191 & 0.9900 * & 0.0000 \\
\hline 24 & Master Comp Mole Frac (Oxygen) & 0.0000 & 0.0000 & 0.0000 & $0.0100 *$ & 1.0000 \\
\hline 25 & Master Comp Mole Frac (Hydrogen) & 0.0803 & 0.6549 & 0.0800 & $0.0000 *$ & 0.0000 \\
\hline 26 & Master Comp Mole Frac (CO) & 0.0196 & 0.1637 & 0.0200 & $0.0000 *$ & 0.0000 \\
\hline 27 & Master Comp Mole Frac (CO2) & 0.1814 & 0.0373 & 0.1810 & $0.0000 *$ & 0.0000 \\
\hline 28 & Master Comp Mole Frac (Methanol) & 0.0000 & 0.0000 & 0.0000 & $0.0000 *$ & 0.0000 \\
\hline 29 & Master Comp Mole Frac (diM-Ether) & 0.0000 & 0.0000 & 0.0000 & $0.0000 *$ & 0.0000 \\
\hline 30 & Master Comp Mole Frac (1-Propanol) & 0.0000 & 0.0000 & 0.0000 & $0.0000 *$ & 0.0000 \\
\hline 31 & Name & 400 & 8 & Warm O2 & 25 & WATER-IN \\
\hline 32 & Master Comp Mole Frac (H2O) & 0.7187 & 0.7191 & 0.0000 & 0.1441 & $1.0000^{*}$ \\
\hline 33 & Master Comp Mole Frac (Oxygen) & 0.0000 & 0.0000 & 1.0000 & 0.0000 & 0.0000 * \\
\hline 34 & Master Comp Mole Frac (Hydrogen) & 0.0803 & 0.0800 & 0.0000 & 0.6549 & 0.0000 * \\
\hline 35 & Master Comp Mole Frac (CO) & 0.0196 & 0.0200 & 0.0000 & 0.1637 & 0.0000 * \\
\hline 36 & Master Comp Mole Frac (CO2) & 0.1814 & 0.1810 & 0.0000 & 0.0373 & 0.0000 * \\
\hline 37 & Master Comp Mole Frac (Methanol) & 0.0000 & 0.0000 & 0.0000 & 0.0000 & 0.0000 * \\
\hline 38 & Master Comp Mole Frac (diM-Ether) & 0.0000 & 0.0000 & 0.0000 & 0.0000 & 0.0000 * \\
\hline 39 & Master Comp Mole Frac (1-Propanol) & 0.0000 & 0.0000 & 0.0000 & 0.0000 & 0.0000 * \\
\hline 40 & Name & CO2-IN & 4 & 5 & 6 & 7 \\
\hline 41 & Master Comp Mole Frac (H2O) & $0.0000 *$ & 0.7191 & 0.7191 & 0.1441 & 0.1441 \\
\hline 42 & Master Comp Mole Frac (Oxygen) & $0.0000 *$ & 0.0000 & 0.0000 & 0.0000 & 0.0000 \\
\hline 43 & Master Comp Mole Frac (Hydrogen) & $0.0000 *$ & 0.0800 & 0.0800 & 0.6549 & 0.6549 \\
\hline 44 & Master Comp Mole Frac (CO) & $0.0000 *$ & 0.0200 & 0.0200 & 0.1637 & 0.1637 \\
\hline 45 & Master Comp Mole Frac (CO2) & $1.0000 *$ & 0.1810 & 0.1810 & 0.0373 & 0.0373 \\
\hline 46 & Master Comp Mole Frac (Methanol) & $0.0000 *$ & 0.0000 & 0.0000 & 0.0000 & 0.0000 \\
\hline 47 & Master Comp Mole Frac (diM-Ether) & $0.0000 *$ & 0.0000 & 0.0000 & 0.0000 & 0.0000 \\
\hline 48 & Master Comp Mole Frac (1-Propanol) & $0.0000 *$ & 0.0000 & 0.0000 & 0.0000 & 0.0000 \\
\hline 49 & Name & 10 & SYNG & 13 & 14 & SYNG-RCY \\
\hline 50 & Master Comp Mole Frac (H2O) & 0.1441 & 0.0260 & 0.9999 & 0.9999 & 0.5427 \\
\hline 51 & Master Comp Mole Frac (Oxygen) & 0.0000 & 0.0000 & 0.0000 & 0.0000 & 0.0000 \\
\hline 52 & Master Comp Mole Frac (Hydrogen) & 0.6549 & 0.7453 & 0.0001 & 0.0001 & 0.3499 \\
\hline 53 & Master Comp Mole Frac (CO) & 0.1637 & 0.1863 & 0.0000 & 0.0000 & 0.0875 \\
\hline 54 & Master Comp Mole Frac (CO2) & 0.0373 & 0.0424 & 0.0000 & 0.0000 & 0.0199 \\
\hline 55 & Master Comp Mole Frac (Methanol) & 0.0000 & 0.0000 & 0.0000 & 0.0000 & 0.0000 \\
\hline 56 & Master Comp Mole Frac (diM-Ether) & 0.0000 & 0.0000 & 0.0000 & 0.0000 & 0.0000 \\
\hline 57 & Master Comp Mole Frac (1-Propanol) & 0.0000 & 0.0000 & 0.0000 & 0.0000 & 0.0000 \\
\hline \begin{tabular}{|l|}
58 \\
59 \\
60 \\
61 \\
62 \\
\end{tabular} & & & & & & \\
\hline 63 & Honeywell International Inc. & UniSi & $m$ Design (R400 Bi & Id 16067) & & Page 3 of 7 \\
\hline
\end{tabular}




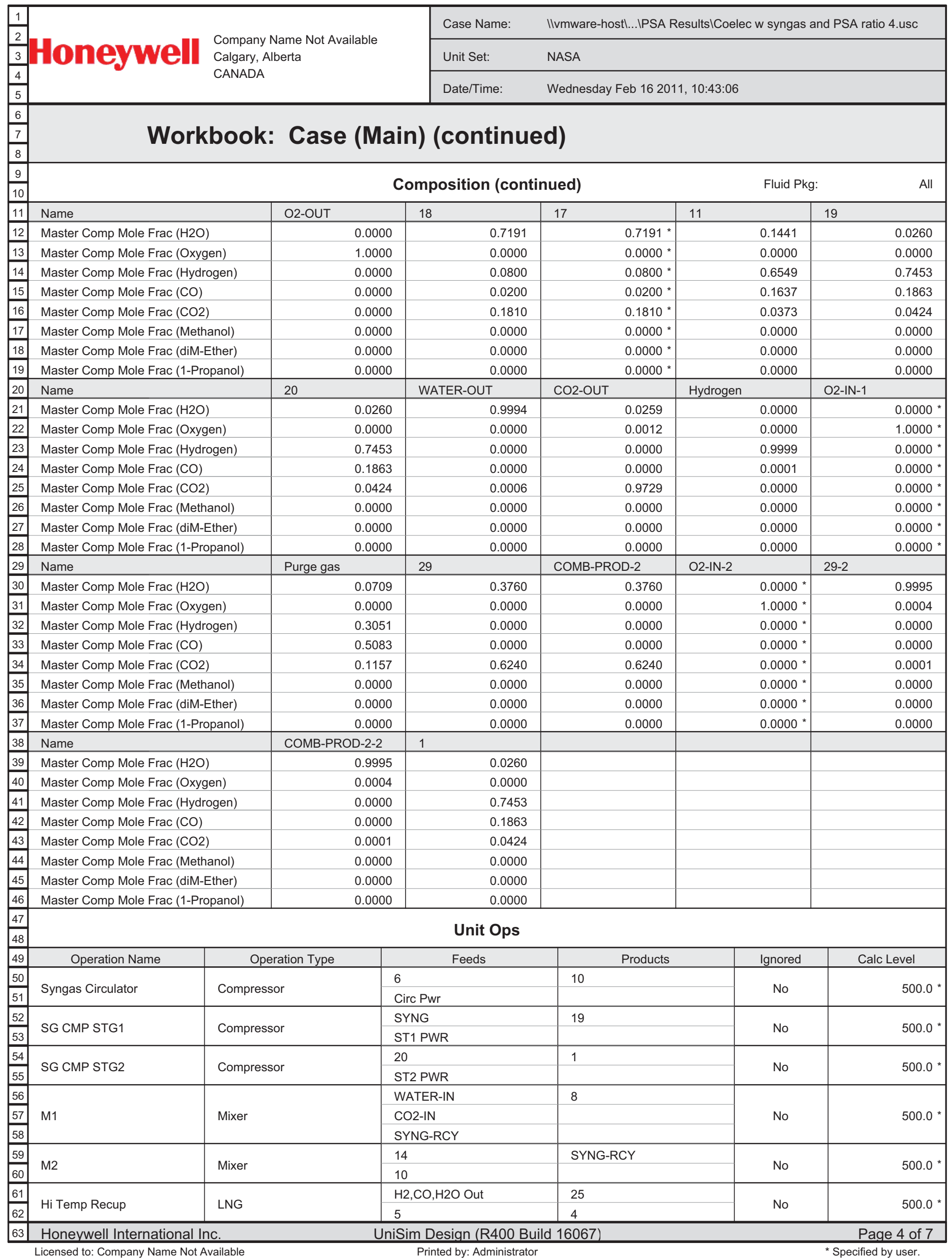




\begin{tabular}{|c|c|c|c|c|c|c|}
\hline 1 & & & Case Name: & |lvmware-hostl...IPSA & w syngas & A ratio 4.usc \\
\hline 3 & Honey & Calgary, Alberta & Unit Set: & NASA & & \\
\hline$\frac{4}{5}$ & & 每 & Date/Time: & Wednesday Feb 1620 & & \\
\hline$\frac{6}{7}$ & Work & book: Case (N & ain) (contin & d) & & \\
\hline$\frac{9}{10}$ & & & Unit Ops (con & ed) & & \\
\hline 11 & Operation Name & Operation Type & Feeds & Products & Ignored & Calc Level \\
\hline 12 & Hi Temp Recup & LNG & Hot O2 & Warm O2 & No & 500.0 * \\
\hline 13 & & & 25 & 11 & & \\
\hline 14 & Lo Temp Recup & LNG & 17 & 18 & No & $500.0 *$ \\
\hline 15 & & & Warm O2 & O2-OUT & & \\
\hline 16 & RWGS 1 & Fquilibrium Reactor & 9 & 400 & No & $5000 *$ \\
\hline 17 & rvvos & 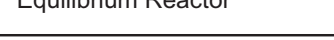 & & $\mathrm{CO} 2$, Water In & INO & 500.0 \\
\hline 18 & & & $\mathrm{O} 2-\mathrm{IN}-1$ & 29 & & \\
\hline 19 & COMBUSTOR 1 & Conversion Reactor & Purge gas & COMB-PROD-2 & No & $500.0 *$ \\
\hline 20 & & & COMB1-Q & COMB1-Q & & \\
\hline 21 & & & O2-IN-2 & $29-2$ & & \\
\hline 22 & COMBUSTOR 2 & Conversion Reactor & Hydrogen & COMB-PROD-2-2 & No & $500.0 *$ \\
\hline 23 & & & COMB-Q-2-2 & COMB-Q-2-2 & & \\
\hline 24 & & & 7 & 13 & & \\
\hline 25 & Water Knockout Tank & Separator & $A m b$ Q & SYNG & No & $500.0 *$ \\
\hline 26 & & & & $\mathrm{Amb} \mathrm{Q}$ & & \\
\hline 27 & & & COMB-PROD-2 & WATER-OUT & & \\
\hline 28 & KO-DRM 2 & Separator & COMB-PROD-2-2 & CO2-OUT & No & $500.0 *$ \\
\hline 29 & & & AMB-Q-1 & AMB-Q-1 & & \\
\hline 30 & INT CI R 1 & Conler & 19 & 20 & $\mathrm{No}$ & 5000 * \\
\hline 31 & IIVI CLR I & Couler & & IC1 Q & INO & 500.0 \\
\hline 32 & $\mathrm{RCY}-4$ & Recycle & 8 & 17 & No & $3500 *$ \\
\hline 33 & T1 & Tee & 11 & 6 & & \\
\hline 34 & 11 & lee & & 7 & No & $500.0^{n}$ \\
\hline 35 & & & Sweep Gas In & Hot O2 & & \\
\hline 36 & Hiah Temnerature Co-Flectrol & Standard Sub-Flowsheet & $\mathrm{CO} 2$, Water In & $\mathrm{H} 2, \mathrm{CO}, \mathrm{H} 2 \mathrm{O}$ Out & $\mathrm{No}$ & 2500 * $>2>0$ \\
\hline 37 & 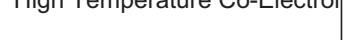 & 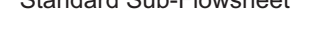 & Process Heat & & INO & 2500 \\
\hline 38 & & & Electrolysis Power & & & \\
\hline 39 & Topoina Heat & Heater & 4 & 9 & & $5000 *$ \\
\hline 40 & Iopping Heat & Heater & Top Heat Q & & No & 500.0 \\
\hline 41 & Preheater & Heater & 18 & 5 & & 5000 * $>2>0$ \\
\hline 42 & Preneater & Heater & Preheat Q & & No & 500.0 \\
\hline 43 & SPRDSHT-1 & Spreadsheet & & & No & $500.0 *$ \\
\hline 44 & PSA Calcs & Spreadsheet & & & No & $500.0 *$ \\
\hline 45 & Water Pump & Pump & 13 & 14 & & 5000 * $>2>0$ \\
\hline 46 & Water Pump & Pump & Water Pump Pwr & & No & 500.0 \\
\hline 47 & & & 1 & Hydrogen & & \\
\hline 48 & PSA & Component Splitter & PSA Power & Purge gas & No & $500.0 *$ \\
\hline 49 & & & PSA heat & & & \\
\hline 50 & SET-1 & Set & & & No & $500.0 *$ \\
\hline 51 & ADJ-1 & Adjust & & & No & $3500 *$ \\
\hline 52 & ADJ-2 & Adjust & & & Yes & 3500 * \\
\hline 53 & & & & & & \\
\hline 54 & & & & & & \\
\hline$\frac{55}{56}$ & & & & & & \\
\hline 57 & & & & & & \\
\hline 58 & & & & & & \\
\hline 59 & & & & & & \\
\hline$\frac{60}{61}$ & & & & & & \\
\hline 62 & & & & & & \\
\hline 63 & Honeywell International In & c. & niSim Design (R400 & d 16067) & & Page 5 of 7 \\
\hline
\end{tabular}




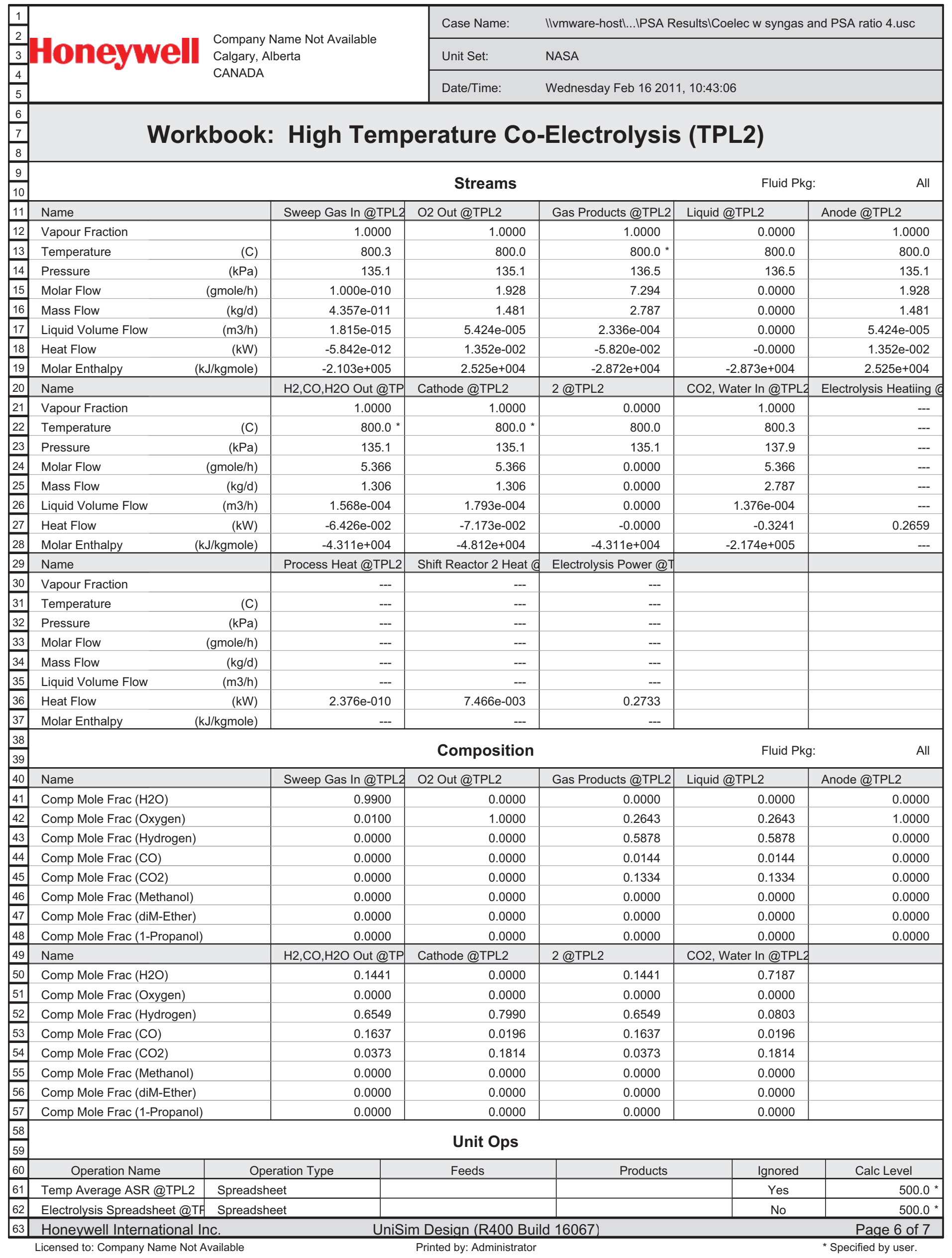




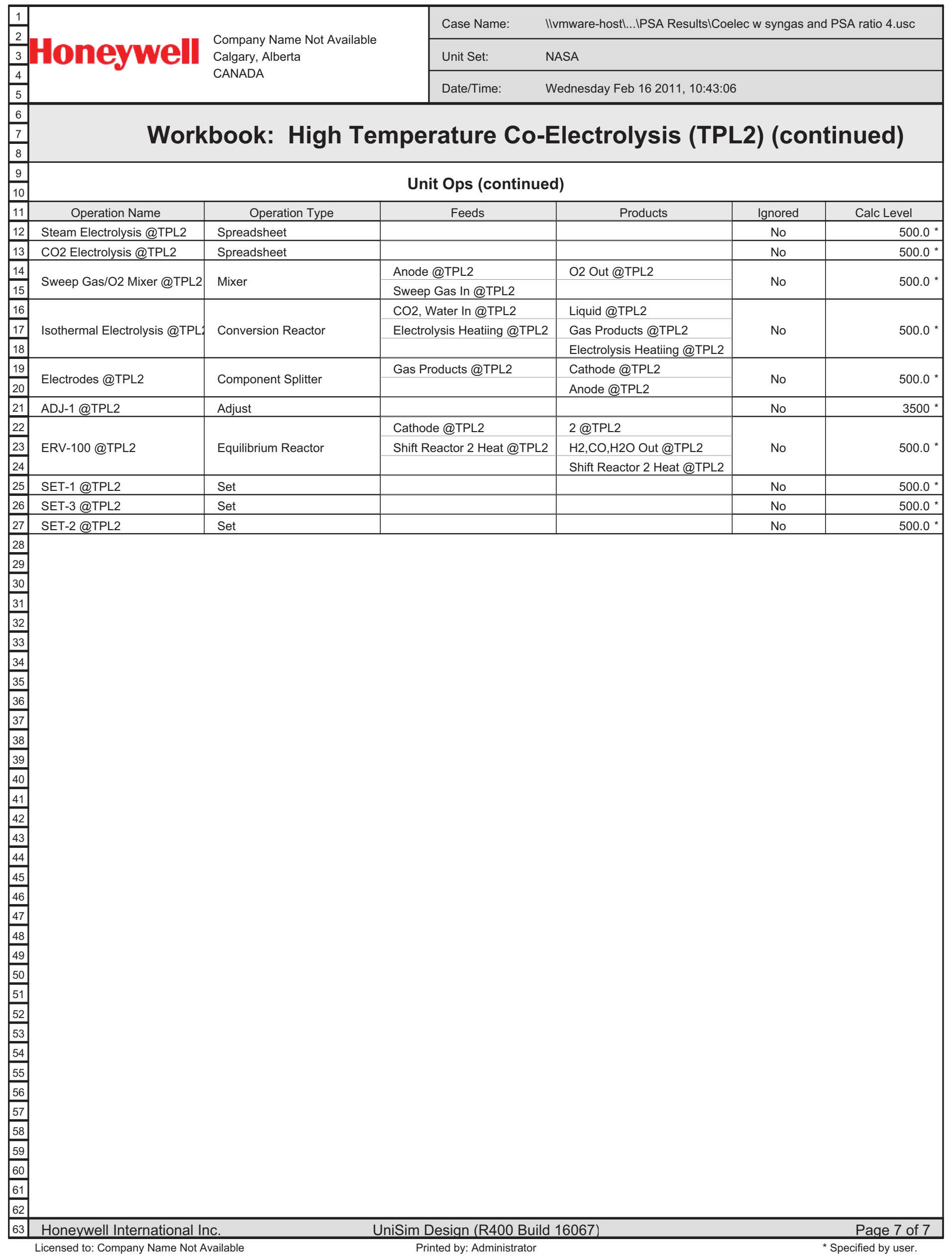

